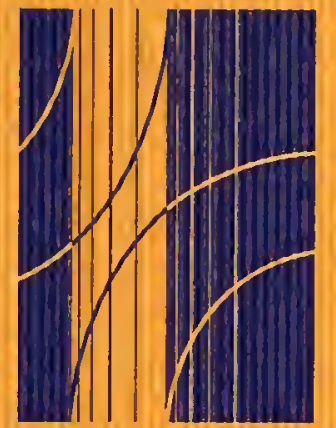

Joint

Transportation

Research

Program

J T R P

FHWA/IN/JTRP-97/13

Final Report

CONDITIONS FOR STRIPPING USING ACCELERATED TESTING

Changlin Pan

Thomas D. White

February 1999

Indiana

Department

of Transportation

Purdue

University 

Final Report

FHWA/TN/JTRP-97/13

\title{
CONDITIONS FOR STRIPPING USING ACCELERATED TESTING
}

\author{
by \\ Changlin Pan \\ and \\ Thomas D. White \\ Joint Transportation Research Program \\ Project No: C-36-55L \\ File No: $2-12-12$ \\ Prepared as Part of an Investigation \\ Conducted by the \\ Joint Transportation Research Program \\ Purdue University \\ In Cooperation with the \\ Indiana Department of Transportation \\ and the \\ U.S. Department of Transportation \\ Federal Highway Administration
}

The contents of this report reflect the views of the authors who are responsible for the facts and accuracy of the data presented herein. The contents do not necessarily reflect the official views or policies of the Federal Highway Administration. This report does not constitute a standard, specification, or regulation.

\section{School of Civil Engineering \\ Purdue University \\ West Lafayette, Indiana 47907}

February 1999 
Digitized by the Internet Archive in 2011 with funding from

LYRASIS members and Sloan Foundation; Indiana Department of Transportation 
TECHNICAL REPORT STANDARD TITLE PAGE

\begin{tabular}{|c|c|c|}
\hline $\begin{array}{l}\text { 1. Report No. } \\
\text { FHWA/N/JTRP/97-13 }\end{array}$ & 2. Government Accession No. & 3. Recipient's Catalog No. \\
\hline \multirow{2}{*}{\multicolumn{2}{|c|}{$\begin{array}{l}\text { 4. Title and Subtitle } \\
\text { Conditions for Stripping Using Accelerated Testing }\end{array}$}} & $\begin{array}{l}\text { 5. Report Date } \\
\text { February } 1999\end{array}$ \\
\hline & & 6. Performing Organization Code \\
\hline \multicolumn{2}{|c|}{$\begin{array}{l}\text { 7. Author(s) } \\
\text { Changlin Pan and Thomas D. White }\end{array}$} & $\begin{array}{l}\text { 8. Performing Organization Report No. } \\
\text { FHWA/N/JTRP-97/13 }\end{array}$ \\
\hline \multirow{2}{*}{\multicolumn{2}{|c|}{$\begin{array}{l}\text { 9. Performing Organization Name and Address } \\
\text { Joint Transportation Research Program } \\
\text { 1284 Civil Engineering Building } \\
\text { Purdue University } \\
\text { West Lafayette, Indiana } 47907-1284\end{array}$}} & 10. Work Univ No. \\
\hline & & $\begin{array}{l}\text { 11. Contract or Grant No. } \\
\text { HPR-2086 }\end{array}$ \\
\hline \multirow{3}{*}{\multicolumn{2}{|c|}{$\begin{array}{l}\text { 12. Sponsoring Agency Name and Address } \\
\text { Indiana Department of Transportation } \\
\text { State Office Building } \\
100 \text { North Senate Avenue } \\
\text { Indianapolis, IN } 46204\end{array}$}} & 13. Type of Report and Period Covered \\
\hline & & Final Report \\
\hline & & 14. Sponsoring Agency Code \\
\hline
\end{tabular}

15. Supplementary Notes

Psepared in cooperation with the Indiana Department of Transportation and Fedesal Highway Administration.

16. Abstract

A laboratory study was conducted to determine water sensitivity and rutting potential of asphalt mixtures. Two major tests were included in the study: AASHTO T-283 and a laboratory wheel tracking device (PURWheel). AASHTO T-283 has been adopted in the Superpave system for evaluating mixture stripping potential. The PURWheel device and test method was developed with the concept creating conditions associated with stripping, i.e. moisture, high temperature, and a moving wheel load. The laboratory wheel track tests can be conducted with hot/wet or hot/dry environments. The objective of the study is to determine the factors that most influence bituminous mixture stripping potential. The laboratory wheel tests can simulate mixture stripping conditions as well pavement loadings. Rutting potential with and without stripping, hot/wet and hot/dry environments, respectively, can be determined independently. The difference in rutting for the two environmental conditions indicates the magnitude of rutting associated with stripping.

PURWheel tests show the abilities of the machine to evaluate the rutting/stripping of asphalt mixtures under various temperature/moisture conditions. In a comparison of two Indiana \#11 surface mixtures, limestone and dolomite, the limestone mix has a lower susceptibility to rutting than that of the dolomite $\mathrm{mix}$ at 50 and $60^{\circ} \mathrm{C}$. Moisture damage was shown to occur over a range of temperatures from $60^{\circ} \mathrm{C}$ to room temperature.

Results of FEM studies show that the creep model can successfully characterize the pavement material behavior through a reasonable approximation of loading and material properties. Based on deformation data from the PURWheel tests, material parameters in the creep model were backcalculated. Good agreement was obtained between predicted and measured deformation in APT tests.

17. Key Words

asphalt, mixtures, Superpave, stripping, AASHTO

T283, wheel testing
20. Security Classif. (of this page)

\section{Distribution Statement}

No restrictions. This document is available to the public through the National Technical Information Service, Springfield, VA 22161
19. Security Classif. (of this report)
21. No. of Pages 190
22. Price 


\section{TABLE OF CONTENT}

Page

LIST OF TABLES vii

LIST OF FIGURES $x$

IMPLEMENTATION REPORT xiv

CHAPTER 1 INTRODUCTION 1

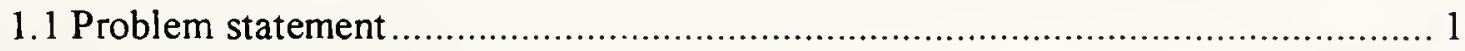

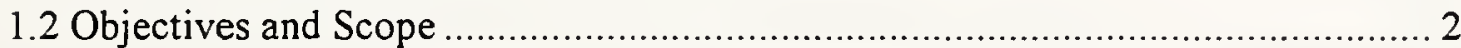

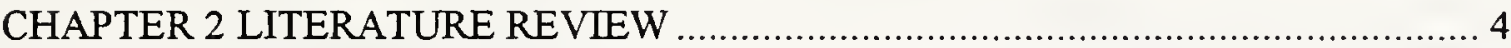

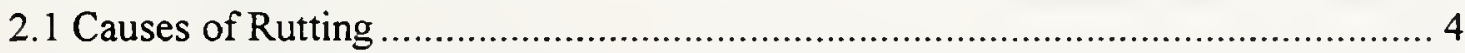

2.1.1 Effect of Load and Tire Pressure on Rutting Potential .......................... 5

2.1.2 Effect of Temperature on Rutting Potential...................................... 6

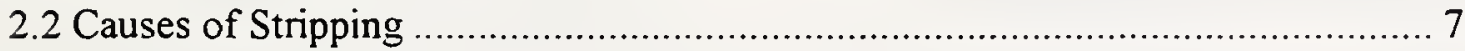

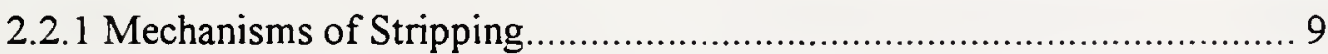

2.2.2 Influence of Aggregate on Stripping Potential .................................. 11

2.2.3 Influence of Anti-Stripping Agents on stripping Potential.................. 11

2.3 Laboratory Moisture Susceptibility Tests................................................... 13

2.3.1 Immersion - Compression test .................................................... 14

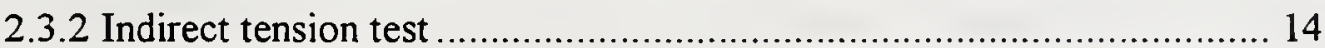

2.3.3 Texas Freeze-Thaw Pedestal Test.................................................. 15 
2.4 Laboratory Accelerated Wheel Tracking Tests 16

3.1 Introduction 25

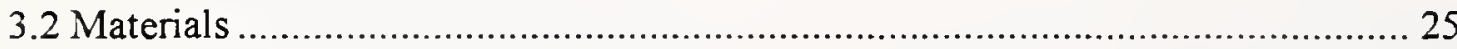

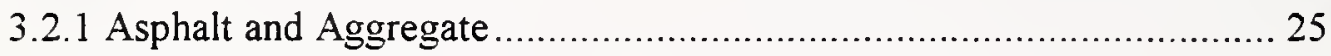

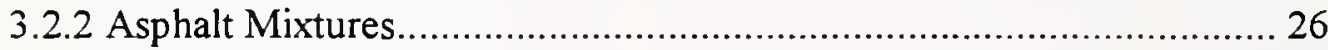

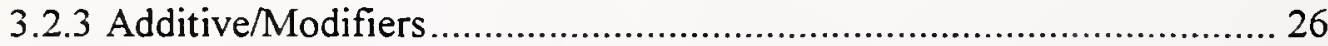

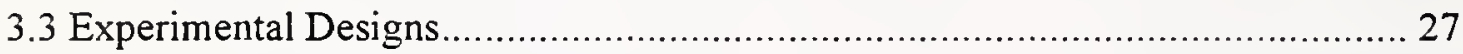

CHAPTER 4 LABORATORY MOISTURE SENSITIVITY TESTS ........................ 40

4.1 Specimen Preparations for AASHTO T-283 Tests ........................................ 40

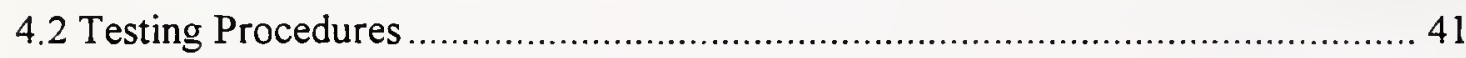

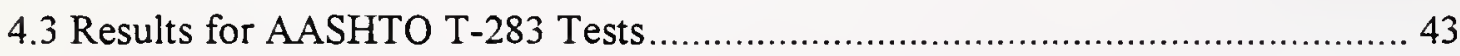

4.3.1 Results for Surface Mixtures ........................................................... 43

4.3.2 Results for Binder Mixtures ................................................................ 43

4.3.3 Results for Base Mixtures ............................................................... 44

4.4 Analysis for AASHTO T-283 Test Results ................................................. 45

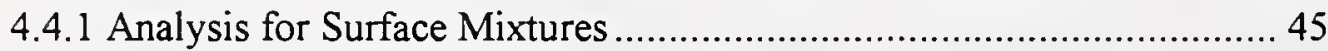

4.4.2 Analysis for Binder Mixtures ......................................................... 46

4.4.3 Analysis for Base Mixtures ............................................................ 47

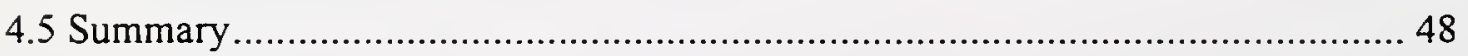

CHAPTER 5 LABORATORY WHEEL TRACKING TESTING …......................... 72

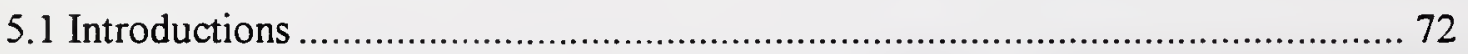

Page

5.2 Laboratory Wheel Test Apparatus Development......................................... 73

5.2.1 Laboratory Linear Compactor .......................................................... 74

5.2.2 Development of The Wheel Track Testing Device ........................... 75 


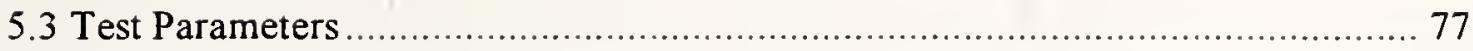

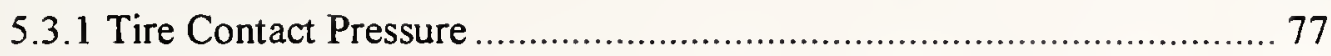

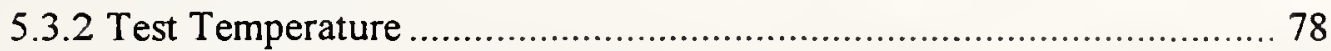

5.4 Sample Preparation and Test Procedures ....................................................... 79

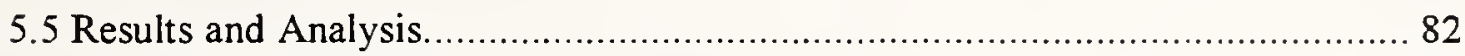

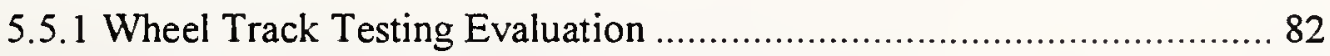

5.5.2 Results and Analysis for Surface Mixtures ................................... 83

5.5.3 Results and Analysis for Binder Mixtures....................................... 85

5.5.4 Results and Analysis for Base Mixtures........................................ 86

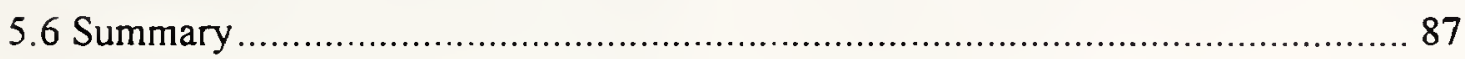

CHAPTER 6 INFLUENCE OF TESTING TEMPERATURE AND MOISTURE ON

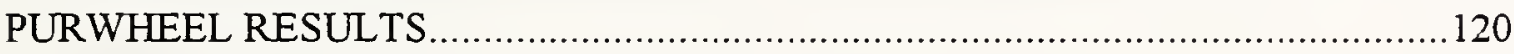

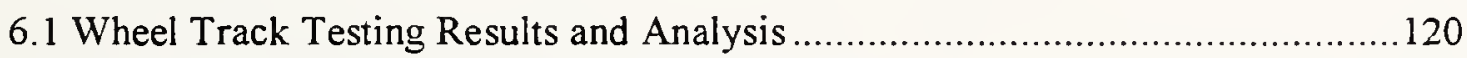

6.1.1 Temperature and Moisture Effects.................................................120

6.1.2 Analysis for the Effect of Temperature and Moisture ........................121

6.2 Finite Element Modeling for the Wheel Tracking Test .................................123

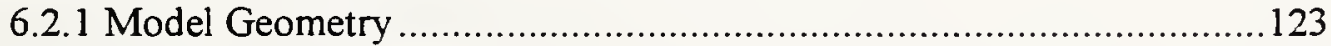

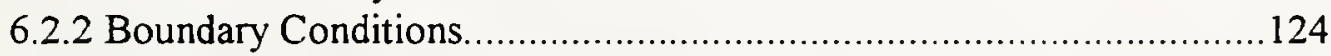

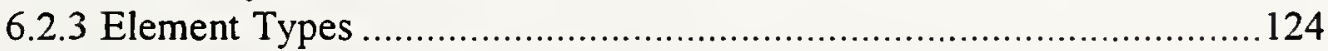

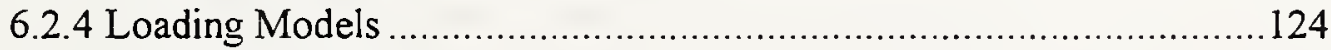

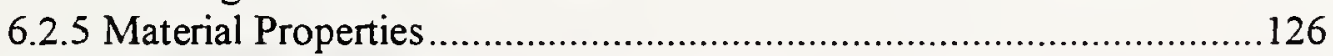

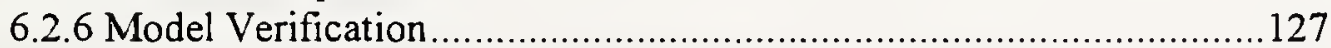

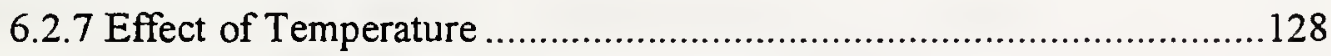

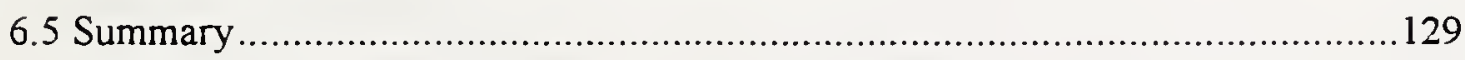

CHAPTER 7 EVALUATIONS OF 1996 SUPERPAVE PROJECTS ........................152

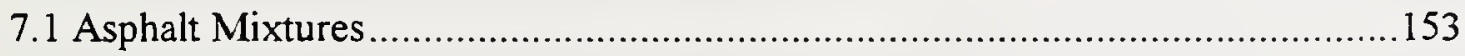

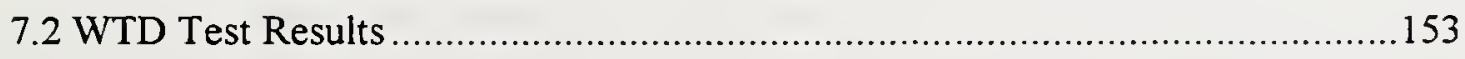

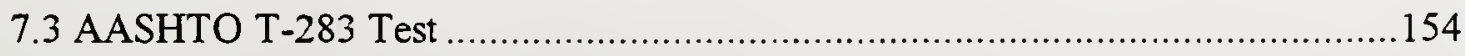


7.4 Summary 155

CHAPTER 8 CONCLUSIONS AND RECOMMENDATIONS 164

LIST OF REFERENCES 169 


\section{LIST OF TABLES}

Table

2.1 Tire Pressure Survey Summary (Okamoto and Packard, 1989) 18

2.2 Test Parameters of the LCPC French Rut Tester (Williams, 1996). 19

2.3 Test Parameters of the Georgia Loaded Wheel Tester (Williams, 1996) 20

2.4 Test Parameters of the Hamburg Steel Wheel Tracking Device (Williams, 1996)

2.5 Recommended Testing Temperature for the Hamburg Wheel Tracking

Device, (Aschenbrener and Currier, 1993) ..................................................... 22

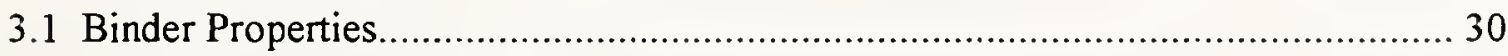

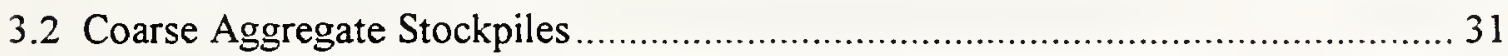

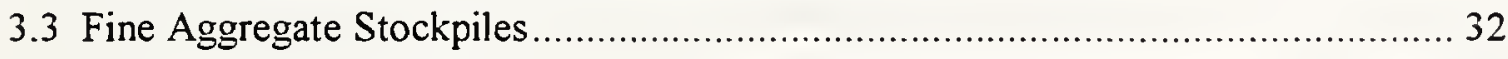

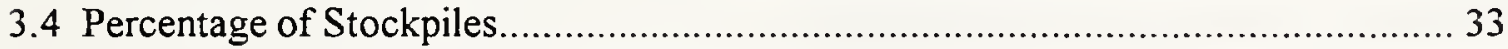

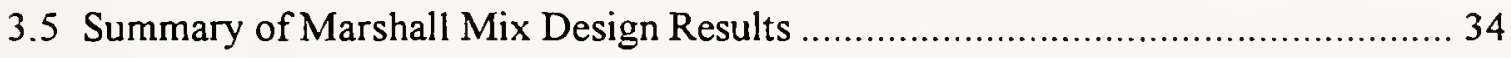

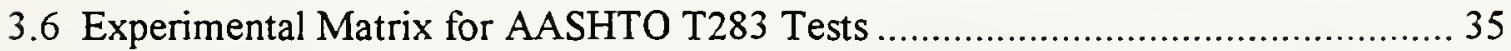

3.7 Experimental Matrix for Laboratory Wheel Tests to Determine the

Influence of Aggregate and Additives/Modifier.................................................... 36

3.8 Experimental Matrix for Laboratory Wheel Tests to Determine the

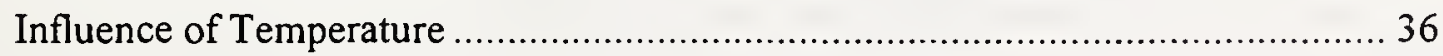

4.1 AASHTO T-283 Test Results for \#11 Dolomite Mixtures .................................... 50

4.2 AASHTO T-283 Test Results for \#1 1 Limestone Mixtures.................................. 51

4.3 AASHTO T-283 Test Results for \#11 Slag Mixtures......................................... 52

4.4 AASHTO T-283 Test Results for \#8 Gravel Mixtures ...................................... 53

4.5 AASHTO T-283 Test Results for \#8 Limestone Mixtures .................................... 54

4.6 AASHTO T-283 Test Results for \#8 Slag Mixtures............................................ 55

Table Page

4.7 AASHTO T-283 Test Results for \#5C Limestone Mixtures................................. 56

4.8 Class Level Information-\#11 Surface Mix ........................................................ 57 
4.9 Summary of Statistical Analysis for \#11 Surface Mixtures .................................. 57

4.10 Mean Comparison of ITS for Different Types of Aggregate (\#11 Surface) .......... 58

4.11 Mean Comparison of ITS for Different Treatments (\#11 Surface) ...................... 58

4.12 Mean Comparison of ITS for Aggregate \& Treatment Interactions

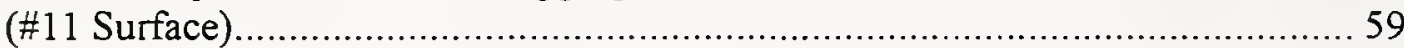

4.13 Mean Comparison of ITS for Moisture \& Treatment Interactions

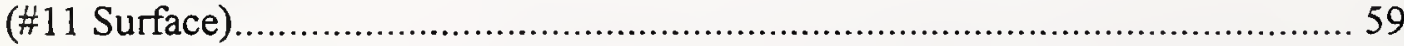

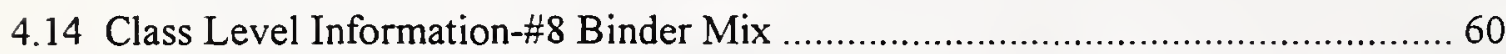

4.15 Summary of Statistical Analysis for \#8 Binder Mixtures ....................................6 60

4.16 Mean Comparison of ITS for Different Types of Aggregate (\#8 Binder) ............. 61

4.17 Mean Comparison of ITS for Aggregate \& Treatment Interactions

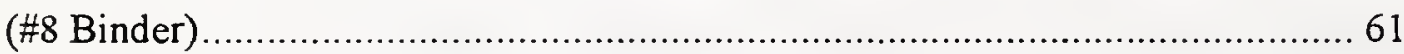

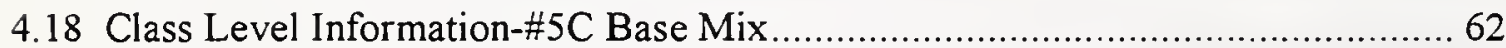

4.19 Summary of Statistical Analysis for \#5C Base Mixtures ..................................... 62

4.20 Mean Comparison of ITS for Different Treatments (\#5C Base) ........................... 63

4.21 Mean Comparison of ITS for Moisture \& Treatment Interactions

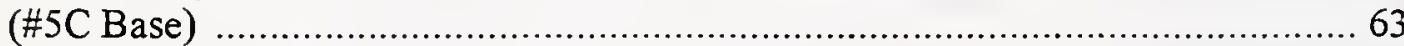

5.1 \# 11 Surface Wheel Track Test Results Summary

(Wheel Passes @12.7 mm Rut) ...................................................................... 88

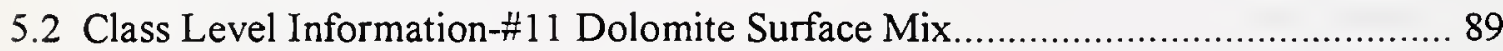

5.3 Summary of Statistical Analysis for \#11 Surface Mixtures .................................. 89

5.4 Class Level Information-\#11 Surface Mix ......................................................... 90

5.5 Summary of Statistical Analysis for \#11 Surface Mixtures .................................. 90

5.6 Mean Comparison of wheel Passes for Different Aggregate Types

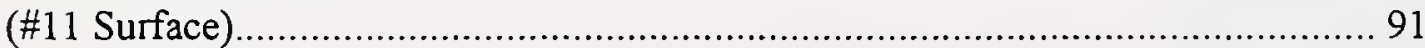

Table

5.7 Mean Comparison of Wheel Passes for Different Treatments

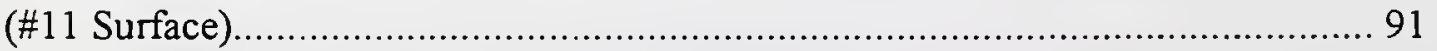

5.8 \# 8 Binder Wheel Track Test Results Summary

(Wheel Passes@12.7 mm Rut) .......................................................................... 92

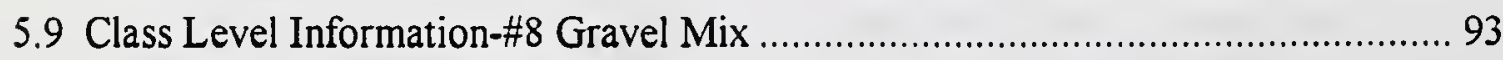

5.10 Summary of Statistical Analysis for \#8 Binder Mixtures ................................ 93 
5.11 Class Level Information-\#8 Binder Mix

5.12 Mean Comparison of Wheel Passes for Different Aggregate Types

(\#8 Binder)

5.13 Mean Comparison of Wheel Passes for Different Aggregate Types

(\#8 Binder).

5.14 \# 5C Base Wheel Track Test Results Summary

(Wheel Passes@6.35 mm Rut) ............................................................................. 95

5.15 Class Level Information-\#5C Base Mix............................................................ 96

5.16 Summary of Statistical Analysis for \#5C Base Mixtures...................................... 96

6.1 Wheel Track Test Results Summary (Wheel Passes @ 12.7 mm Rut)..................131

6.2 Statistical Values for Temperature/Moisture Regression Models ............................132

6.3 Parameter Estimates - \#11 Limestone Mix......................................................132

6.4 Parameter Estimates - \#11 Dolomite Mix ..............................................................133

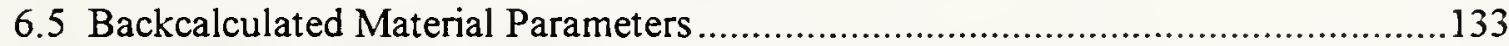

7.1 Summary of Superpave Volumetric Mix Design Results ....................................156

7.2 Summary of WTD Test Results (at $12.7 \mathrm{~mm}$ Rut) .........................................157

7.3 AASHTO T-283 Test Results (102 mm specimens)..........................................158

7.4 AASHTO T-283 Test Results (150 mm specimens)...........................................159 


\section{LIST OF FIGURES}

Figure

2.1 Schematic representation of Aggregate-asphalt interface model

(Gzemski, et al., 1968)

2.2 Schematic representation of "roll-back" interface model

(Gzemski, et al., 1968)

2.3 Schematic representation of "lift-off" interface model

(Gzemski, et al., 1968) 24

3.1 \#11 Surface Mixture Gradations. 37

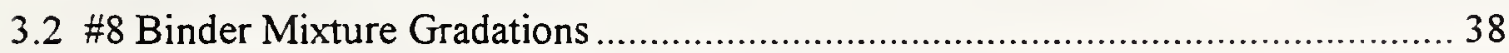

3.3 \#5C Open Gradation Base Mixture Gradations ................................................. 39

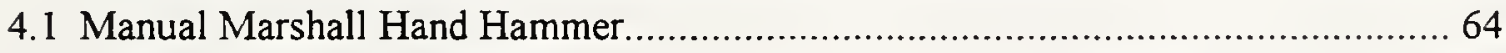

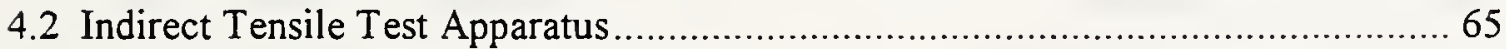

4.3 Indirect Tensile Strength for \#11 Dolomite Mix ...................................................6

4.4 Indirect Tensile Strength for \#11 Limestone Mix..................................................6 66

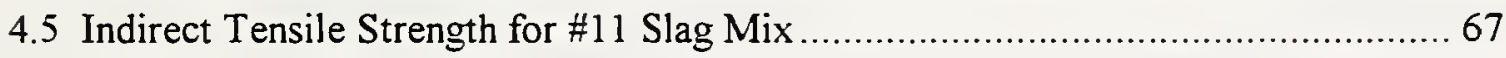

4.6 Indirect Tensile Strength for \#8 Gravel Mix ....................................................... 67

4.7 Indirect Tensile Strength for \#8 Limestone Mix.....................................................6 68

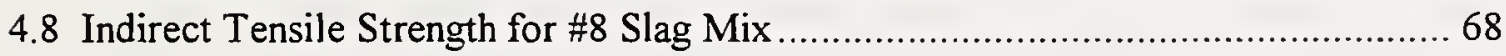

4.9 Indirect Tensile Strength for \#5C Limestone Mix ................................................. 69

4.10 Plot of Mean Indirect Tensile Strength by Aggregate and Treatment

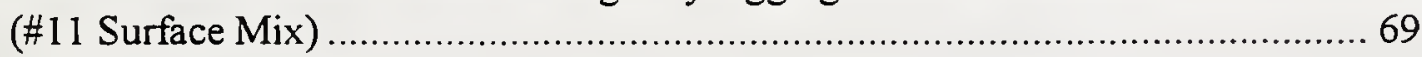

4.11 Plot of Mean Indirect Tensile Strength by Moisture and Treatment

(\#11 Surface Mix) 
Figure

4.12 Plot of Mean Indirect Tensile Strength by Moisture and Treatment

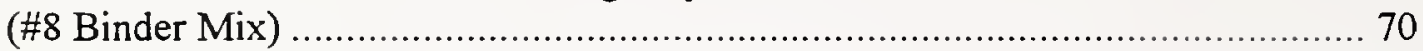

4.13 Plot of Mean Indirect Tensile Strength by Moisture and Treatment (\#5C Base Mix)..

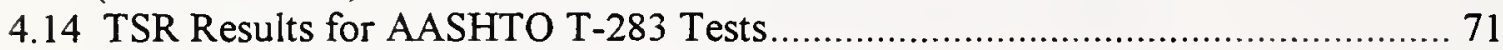

5.1 Purdue Wheel Track Testing Device ................................................................. 97

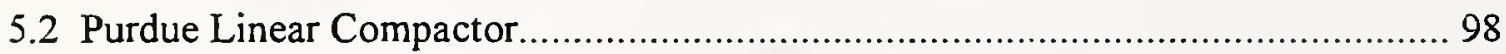

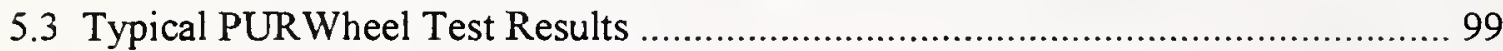

5.4 Linear Compactor Steel Mold Feature ...............................................................100

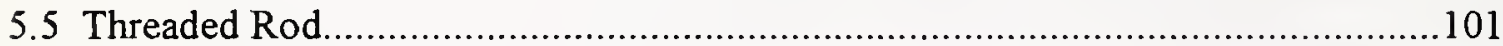

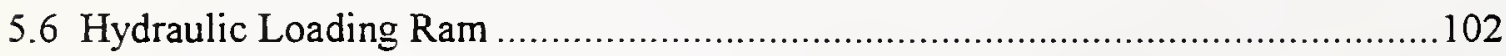

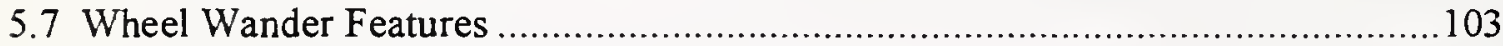

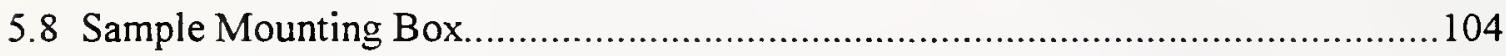

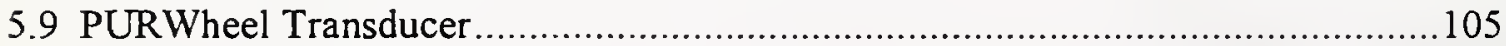

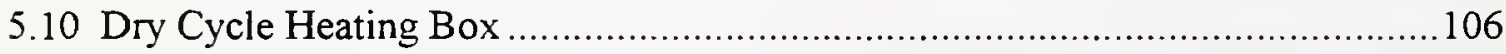

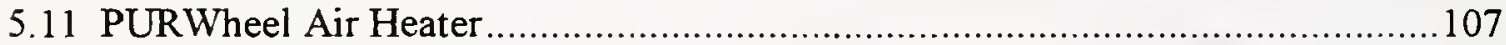

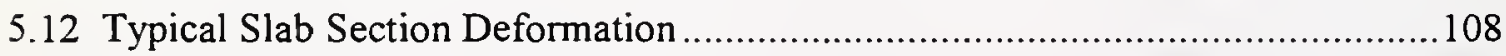

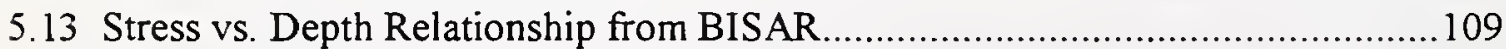

5.14 Highest Hourly Pavement Surface Temperature for Indiana (1993) ...................110

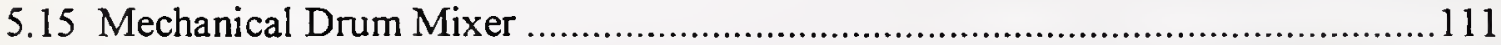

5.16 Relationship Between PURWheel Deformation and Measured Rut Depth ..........112

5.17 Wheel Track Test Results of Dolomite Surface Mixture, Control ......................113

5.18 Wheel Track Test Results of Dolomite Surface Mixture, Liquid Additive...........113

5.19 Wheel Track Test Results of Dolomite Surface Mixture, Hydrated Lime ............114

5.20 Wheel Track Test Results of Limestone Surface Mixture, Control......................114

5.21 Wheel Track Test Results of Slag Surface Mixture, Control ..............................115

5.22 Wheel Track Test Results of Gravel Binder Mixture, Control .........................115

5.23 Wheel Track Test Results of Gravel Binder Mixture, Liquid Additives ..............116

Figure Page

5.24 Wheel Track Test Results of Gravel Binder Mixture, Hydrated Lime ................116

5.25 Wheel Track Test Results of Limestone Binder Mixture, Control .....................117

5.26 Wheel Track Test Results of Slag Binder Mixture, Control ..............................117 
5.27 Wheel Track Test Results of Limestone Base Mixture, Control .........................118

5.28 Wheel Track Test Results of Limestone Base Mixture, Liquid Additives.............118

5.29 Wheel Track Test Results of Limestone Base Mixture, Hydrated Lime ............. 119

5.30 Typical Rutting and Corrugation Distress on I-64 ..........................................119

6.1 Wheel Track Test Results of Dolomite Surface Mixture, $60^{\circ} \mathrm{C}$.........................134

6.2 Wheel Track Test Results of Dolomite Surface Mixture, $50^{\circ} \mathrm{C}$.......................... 134

6.3 Wheel Track Test Results of Dolomite Surface Mixture, $40^{\circ} \mathrm{C}$...........................135

6.4 Wheel Track Test Results of Dolomite Surface Mixture, $30^{\circ} \mathrm{C}$..........................135

6.5 Wheel Track Test Results of Dolomite Surface Mixture, $25^{\circ} \mathrm{C}$.........................136

6.6 Wheel Track Test Results of Limestone Surface Mixture, $60^{\circ} \mathrm{C}$.........................136

6.7 Wheel Track Test Results of Limestone Surface Mixture, $50^{\circ} \mathrm{C}$.........................137

6.8 Wheel Track Test Results of Limestone Surface Mixture, $40^{\circ} \mathrm{C}$..........................137

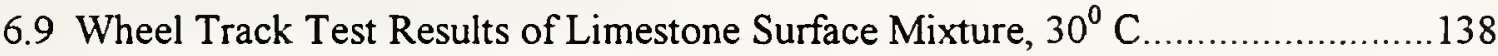

6.10 Wheel Track Test Results of Limestone Surface Mixture, $25^{\circ} \mathrm{C}$........................138

6.11 Temperature-Rutting Rate Relationship for \#11 Limestone Mix .........................139

6.12 Temperature-Rutting Rate Relationship for \#11 Dolomite Mix ..........................139

6.13 Cross Section of PURWheel Test Pit ............................................................. 140

6.143 -D View of Finite Element Mesh ...............................................................141

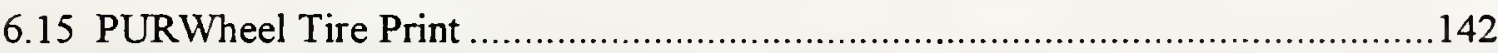

6.16 Step Load Function in the FEM. Analysis................................................... 143

6.17 Permanent Deformation Response of the Finite Element Model

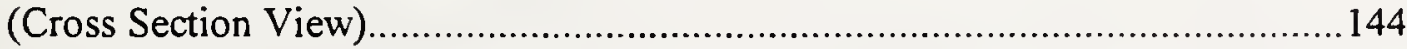

6.18 Creep Model Fitted Curves (\#8 Gravel Mix).................................................. 145

6.19 APT Test Results and Predicted Deformation Curves ........................................145

6.20 Fitted Curves (\#11 Limestone Surface Mixture, $60^{\circ} \mathrm{C}$ )..................................... 146

Figure Page

6.21 Fitted Curves (\#1 1 Limestone Surface Mixture, $50^{\circ} \mathrm{C}$ )....................................146

6.22 Fitted Curves (\#11 Limestone Surface Mixture, $40^{\circ} \mathrm{C}$ )...................................147

6.23 Fitted Curves (\#11 Limestone Surface Mixture, $30^{\circ} \mathrm{C}$ )......................................147

6.24 Fitted Curves (\#11 Limestone Surface Mixture, $25^{\circ} \mathrm{C}$ ).................................... 148

6.25 Fitted Curves (\#11 Dolomite Surface Mixture, $60^{\circ} \mathrm{C}$ ) ...................................... 148

6.26 Fitted Curves (\#11 Dolomite Surface Mixture, $50^{\circ} \mathrm{C}$ ) .....................................149 
xiii

6.27 Fitted Curves (\#11 Dolomite Surface Mixture, $40^{\circ} \mathrm{C}$ ) 149

6.28 Fitted Curves (\#11 Dolomite Surface Mixture, $30^{\circ} \mathrm{C}$ ) 150

6.29 Fitted Curves (\#11 Dolomite Surface Mixture, $25^{\circ} \mathrm{C}$ ) 150

6.30 Effect of Temperature on Parameter $m$ .151

7.1 Wheel Track Test Results of R-21467, $12.5 \mathrm{~mm}$ Mixture 160

7.2 Wheel Track Test Results of R-22350, 9.5 mm Mixture 160

7.3 Wheel Track Test Results of R-22170, $9.5 \mathrm{~mm}$ Mixture 161

7.4 Wheel Track Test Results of R-22403, 19.0 mm Mixture 161

7.5 Wheel Track Test Results of R-22170, $19.0 \mathrm{~mm}$ Mixture 162

7.6 Wheel Track Test Results of R-22687, 25.0 mm Mixture 162

7.7 TSR Results for AASHTO T-283 Tests (Superpave Mixes) 163 


\section{IMPLEMENTATION REPORT}

Several implementable results were obtained from HPR-2086, Conditions for Stripping Using Accelerated Testing. The implementation results include recommendations to adopt the Purdue University laboratory wheel (PURWheel) tracking device, discontinue use of $150 \mathrm{~mm}$ diameter Superpave gyratory compacted cores for AASHTO T-283. tests until an effective conditioning protocol is identified, conduct additional research to identify an acceptable level of tensile strength in lieu of the tensile strength ratio in AASHTO T-283, and additional research on effectiveness of anti-stripping agents.

The PURWheel was developed with a primary goal of evaluating mixtures over a range of temperature in both wet and dry environments. Rutting results in wet conditions or a ratio of wet and dry results were projected as a means of evaluating mixture stripping potential.

For ease of use, a maximum wheel path rut depth of $10 \mathrm{~mm}$ at 20,000 passes is recommended for hot/wet test conditions. For these test conditions, the sample is submerged in water. Recommended test temperatures were $60^{\circ} \mathrm{C}$ for surface mixtures $(9.5 \mathrm{~mm})$ and $57.5^{\circ} \mathrm{C}$ for intermediate mixtures $(12.5 \mathrm{~mm}$ and $19 \mathrm{~mm})$.

The study also included a significant number of PURWheel tests of hot mix asphalt (HMA) mixtures in hot/dry conditions. These results indicated that the dry rutting performance reflected the effects of a number of HMA mixture factors. The PURWheel proved to be an effective tool for evaluating HMA mixture stripping potential in a hot/wet environment. As well as exhibiting potential for evaluating HMA mixture hot/dry rutting potential. Consequently, it is recommended that the Indiana Department of Transportation (INDOT) fund development of a PURWheel device for use in the Division of Materials and Tests laboratory. 
The study also addressed AASHTO T-283 "Resistance of Compacted Bituminous Mixtures to Moisture Induced Damage". Tests were conducted to compare stripping characteristics of $102 \mathrm{~mm}$ cores compacted with the Marshall effort to $150 \mathrm{~mm}$ SGC compacted cores. Results indicated that the current conditioning is not effective for the $150 \mathrm{~mm}$ cores. Comparison of tensile strength ratio (TSR) from AASHTO T-283 and PURWheel results indicate that the TSR does not reflect a mixture stripping/rutting potential as well as the PURWheel. As a result, recommendations were made to discontinue use of the $150 \mathrm{~mm}$ SGC cores until effective conditioning is identified. In such future research a pass/fail test criteria is desired. Or, alternatively, it may be feasible to use $102 \mathrm{~mm}$ diameter cores prepared with the SGC. An NCHRP study is currently underway to address this issue. If the NCHRP study is not successful in developing conditioning then additional research is recommended for that purpose.

In application of AASHTO T-283, a tensile strength ratio is produced. Mixtures not sensitive to moisture are supposed to have a ratio higher than a certain value. Data from the study indicates that anti-stripping agents may be achieving an increase of this ratio by lowering the "dry" strength more than the "wet" strength. Use of the ratio masks this effect which is not desirable. It is recommended that a minimum $600 \mathrm{kPa}$ "wet" tensile strength can be utilized.

A limited number of anti-stripping agents were incorporated in the study. Indications are that hydrated lime is a reasonably effective anti-stripping agent. However, it is recommended that a greater number of liquid anti-stripping agents along with hydrated lime should be tested. An additional study is recommended that would utilize both AASHTO T-283 and PURWheel tests can be conducted to develop/verify minimum tensile strength as well as the allowable rutting criteria. There is also a need for research on long term performance of anti-stripping materials. 


\section{CHAPTER 1 INTRODUCTION}

Asphalt pavement permanent deformation is a significant distress relative to performance. The reason for excessive permanent deformation can be due to an increase in traffic volume, loads and tire pressure as well as environmental conditions, such as moisture and temperature.

Over the last few years state highway agencies have been increasingly concerned about bituminous mixture stripping. Stripping was suggested as a fourth distress type to be considered in the Superpave system. However, the position taken was that stripping distress could not be identified from the surface. In fact, stripping in the field can be identified by an experienced pavement engineer. Manifestation of traffic induced stripping is the appearance of rutting where the uplift and flow from shear failure centered on the wheel path has an irregular width. The distress may also appear as a localized shear failure. Stripping distress can be severe and develop quickly.

\section{$\underline{1.1 \text { Problem statement }}$}

Stripping, according to Roberts, et al. (1991), is the result of the weakening or eventual loss of the adhesive bond of the asphalt from aggregate in the presence of moisture in a hot mix asphalt (HMA) pavement. This may occur from separation of the 
asphalt film from the aggregate surface or from emulsification of the asphalt. In addition, loss of cohesion is another form of stripping. Loss of cohesion is the failure of the bond within the asphalt. Parker and Gharaybeh (1987) state that cohesive failure can increase a chance of adhesive failure.

Causes of stripping are related to moisture. A number of tests are used to determine the moisture susceptibility of an asphalt mixture. However, some of the test results are subjective, also, some of the tests have tenuous correlation with actual field performance. There is increasing interest in using a small-scale wheel tracking device to evaluate the performance of asphalt mixtures. With adequate control of temperature, moisture and wheel load, both rutting performance and moisture susceptibility of asphalt concrete can be examined using such a device.

This research work involves simulating the conditions for stripping of asphalt mixtures. Conditions include heat, moisture, and moving pneumatic wheel load. The Purdue Wheel Tracking Device (PURWheel) has shown potential for evaluating asphalt mixture stripping and rutting. Tests can be conducted on laboratory compacted specimens as well as specimens taken from in-service pavements. Several preliminary test results demonstrate that stripping can be created in laboratory controlled environments. Test data also show that stripping can be examined without subjective judgment. 


\subsection{Objectives and Scope}

The goal of this study is to determine factors that influence asphalt mixture stripping/rutting potential. Two major variables were selected for the research, aggregate type and antistripping additive. These variables are used in the experimental designs to characterize the bituminous mixture performance relative to environmental factors such as moisture and temperature.

A laboratory study was undertaken to determine the moisture sensitivity and rutting potential of asphalt mixtures. Rutting, fatigue and thermal cracking are distresses usually considered in characterizing asphalt pavement performance. In fact, those are the distresses used in setting the Superpave mix design criteria. Currently, mixture stripping potential in the Superpave system is evaluated with AASHTO T-283 (AASHTO, 1995). Both AASHTO T-283 and the PURWheel laboratory wheel tracking device were incorporated into the research plan. The latter equipment was developed specifically for the study.

The report contains seven chapters. A review of literature on stripping of bituminous mixtures and accelerated wheel track testing devices is included in Chapter Two. Chapter Three presents discussion of materials and the experimental design. Chapter Four presents the laboratory testing procedures for AASHTO T-283 tests. Chapter Five presents the tests performed with the laboratory wheel tracking device. Chapter Six presents the finite element prediction model and the influence of testing temperature and moisture on the PURWheel test results. Conclusions and recommendations are presented in Chapter Seven. 


\section{CHAPTER 2 LITERATURE REVIEW}

This chapter reviews the literature regarding causes of stripping and rutting, as well as the current literature used in moisture susceptibility tests. These tests usually involve subjective judgment or the ratio of physical properties (such as strength) to predict moisture susceptibility of the bituminous mixture.

\subsection{Causes of Rutting}

Rutting is the result of a permanent deformation in the pavement layers because of traffic loads. It can be divided into two stages. The first rutting stage is called the postcompaction stage. During this stage, void contents of hot mix asphalt (HMA) surfaces are reduced because of densification. After the initial stage, further rutting is caused by plastic flow of the asphalt mixture(Roberts, et al., 1991). According to Kruger et al. (1985), the rutting problem primarily falls into three categories:

1. Excessive traffic consolidation in the upper portion of the pavement,

2. Plastic deformation due to insufficient mixture stability, and

3. Instability caused by stripping of asphalt below the riding surface. 


\subsubsection{Effect of Load and Tire Pressure on Rutting Potential}

In recent years, the effect of increased truck tire pressure has become an important issue in the performance of bituminous concrete pavements. A study by Roberts et al. (1985) showed that actual tire pressures are much higher than 90 psi (621 $\mathrm{kPa}$ ) which are used in design procedures. He reported that the average tire inflation pressures were between 95 and 100 psi $(655$ to $690 \mathrm{kPa}$ ). Table 2.1 illustrated a nationwide survey of five-axle tractor semi-trailer truck tire inflation pressures (Okamoto and Packard, 1989). In this study, approximately $83 \%$ of the maximum rated tire pressures were between 95 to $110 \mathrm{psi}(655$ to $758 \mathrm{kPa})$. One reason for increasing tire inflation pressures is to reduce rolling resistance. Test data suggested that increasing tire inflation pressure by $10 \mathrm{psi}(69 \mathrm{kPa})$ would result in a $2-1 / 2 \%$ decrease in rolling resistance and theoretically decrease fuel consumption $1 \%$.

Increased tire pressure is related to increased asphalt pavement rutting and accelerated loss of serviceability. Bonaquist et al. (1988) concluded that the effect of increasing tire pressure from 76 to $140 \mathrm{psi}$ ( 524 to $965.3 \mathrm{kPa}$ ) is equivalent to a 2,000 lb. $(8.9 \mathrm{kN})$ axle load increase. This equivalency is for the fatigue damage of the pavement.

\subsubsection{Effect of Temperature on Rutting Potential}

Many bituminous pavements are experiencing premature and significant rutting even though the paving materials passed every current mix design criteria. Many 
researchers associate this problem with properties of the binder. In bituminous concrete pavements, the binder (bitumen) is a temperature susceptible material because of its viscoelastic material characteristics. That is, the stiffness of bitumen can vary with respect to the change of temperature. The change in bitumen stiffness results in a stiffness change of the bituminous mixture. Huekelom and Klomp (1964) introduced the following equation to obtain the mixture stiffness if the bitumen is known.

$$
S_{m}=S_{b}\left[1+\left(\frac{2.5}{n}\right)\left(\frac{C_{v}}{1-C_{v}}\right)\right]^{n}
$$

where $\mathrm{S}_{\mathrm{m}}=\operatorname{mix}$ stiffness $\left(\mathrm{kg} / \mathrm{cm}^{2}\right)$

$$
\begin{aligned}
\mathrm{S}_{\mathrm{b}} & =\text { Bitumen stiffness }\left(\mathrm{kg} / \mathrm{cm}^{2}\right) \\
\mathrm{n} & =0.83 \log _{10}\left[\left(4 \times 10^{5}\right) / \mathrm{S}_{\mathrm{b}}\right] \\
\mathrm{C}_{\mathrm{v}} & =\text { Volume of aggregate } /\left(\mathrm{V}_{\text {aggregate }}+\mathrm{V}_{\text {asphalt }}\right)
\end{aligned}
$$

Equation 2.1 is applicable for a bituminous mixture with air voids of about 3 percent and a $C_{v}$ value between 0.7 and 0.9. Van Draat and Sommer (1965) recommended a modification to $C_{v}$ such that,

$$
C_{v}^{\prime}=\frac{C_{v}}{1-H}
$$


and $\quad C_{B} \geq \frac{2}{3}\left(1-C_{v}^{\prime}\right)$

where $\mathrm{H}=$ Actual air voids -0.03

$$
C_{B}=V_{\text {asphalt }} /\left(V_{\text {aggregate }}+V_{\text {asphalt }}\right)
$$

Decker and Goodrich (1989) indicated that a high viscosity bitumen resulted in a stiffer mix at a given temperature and loading rate. At high ambient temperature, bitumen viscosity is less important than its elastic modulus. Bituminous cement with high elastic modulus increases rutting resistance of the mix.

\subsection{Causes of Stripping}

In 1938, Hubbard wrote, "Stripping of asphalt from mineral aggregate surfaces in the presence of water is no new phenomenon in the field of highway engineering. It has been observed at times ever since asphalt paving came into existence." Stripping is the loss of the adhesive bond between the bitumen and the aggregate surface. The water accumulates between the asphalt film and the aggregate surface because of the hydrophilic characteristics of the aggregate. A Canadian publication (Pavement Management Systems Limited, 1983) included a specific list of factors causing stripping and they are as follows:

1. mineral and chemical composition of aggregates; 
2. exposure history of aggregates (e.g. freshly crushed versus days of exposure to environmental weathering after crushing);

3. original properties of asphalt cement (physical and chemical);

4. modifications in bitumen cement during storage and handling;

5. interactions between individual aggregates, bitumen cements, and additives (if included);

6. water content in the mixes;

7. curing variables (e.g. time, temperature);

8. nature of water to which mix is exposed (salt content, $\mathrm{pH}$ );

9. bitumen content; and

10. special field variables (e.g. climate, construction quality, etc.).

Scherocman, et al. (1986) indicated that the coarse and fine aggregate characteristics are important factors related to moisture damage. There is some evidence that moisture damage can be minimal if stripping is restricted only to the coarse aggregate (Kennedy, et al., 1982). If the fine aggregate strips, severe damage can occur because the fine aggregate constitutes the basic matrix of the mixture.

Scherocman (1986) also stated that the air void content of the mixture can be another important factor related to stripping. At air void content greater than 6 percent, a given mixture can be severely damaged when subjected to moisture and traffic. As the air void content in the mix decreases down to $2-3$ percent, the amount of moisture damage sustained by the same mix is also reduced since very little moisture can move through the mix at that air void ratio. 


\subsubsection{Mechanisms of Stripping}

There are several ways that moisture can affect bituminous mixtures. Once moisture accesses the mix, the mix structure is weakened. The mix losses stiffness, and it fails under repeated traffic loading.

Taylor and Khosla (1983) listed five mechanisms for the asphalt film to be stripped from an aggregate surface. These mechanisms may act individually or together.

1. Detachment,

2. Displacement,

3. Spontaneous emulsification,

4. Pore pressure, and

5. Hydraulic scouring.

The last two mechanisms result from the moving traffic loads and usually happen underneath the pavement surface. It has been suggested by Gzemski, et al. (1968) that the role of traffic includes a mechanical separation of the asphalt film from the aggregate. They also suggested that traffic is directly related to the hydraulic scouring mechanism. According to Fromm (1974), high pore pressure can develop with densification of the paving mixture as a result of traffic loading. The high pore pressure in the mixture is associated with stripping. 
An aggregate-asphalt interface thermodynamic stripping model has been presented by Gzemski, et al. (1968). It contains a three phase interface relation and is illustrated in Fig. 2.1. The binder can be spontaneously removed from the aggregate surface by one of two ways, illustrated in Fig. 2.2 and 2.3. The condition illustrated in Figure 2.2 is called the "roll-back" case and in Figure 2.3 the "lift-off" case. Expressions for the free energy change can be written as follows. For the "roll-back" case

$$
\Delta F_{1}=\gamma_{A W}-\gamma_{A B}-c_{1 *} \gamma_{B W}
$$

where $\Delta \mathrm{F}_{1}=$ free surface energy changes,

$\dot{\gamma} s=$ the interfacial tensions for appropriate interfaces

$c_{1}=$ per unit change of destroyed bitumen-water interface/ per unit change of the other two destroyed interfaces and $c_{1}<1$.

For the "lift-off" case, the free energy change is

$$
\Delta \mathrm{F}_{2}=\gamma_{\mathrm{AW}}-\gamma_{\mathrm{AB}}+\gamma_{\mathrm{BW}}
$$

If the free energy changes given in Eq. (2.5) and (2.6) are negative, the process can occur spontaneously. These two equations also shows that when the interfacial 
tensions are equal, the "roll-back" case of stripping is more likely than the "lift-off" case.

\subsubsection{Influence of Aggregate on Stripping Potential}

Aggregates mineralogical and chemical composition are important factors in the moisture susceptibility of a bituminous mixture (Roberts, et al., 1991). Aggregates are usually classified as being either hydrophilic (water loving) or hydrophobic (water hating). Hydrophilic aggregates, such as quartz and siliceous gravel, appear to have a greater affinity for water than for bitumen cement, and they tend to be acid in nature. On the other hand, hydrophobic aggregates, such as limestone and other carbonate rocks, are considered to be chemically basic and have a low silica content.

Aggregates surface physical characteristics such as texture and particle shapes have been shown to be related to the occurrence of stripping in bituminous pavements. Graf (1986) indicated that limestone aggregates have much longer Texas Freeze-Thaw Pedestal Test lives than dolomite aggregates. He mentioned that the dolomite appears as thin flakes of fairly uniform size, but the limestone includes a wide range of particle shapes and sizes with much less symmetry. Those factors promote more aggregate interlock resulting in an inherently stronger lattice. 


\subsubsection{Influence of Anti-Stripping Agents on Stripping Potential}

Additives have been used for a number of years to reduce or eliminate bituminous mixture stripping problems. Tunniciff and Root (1984) define antistripping additives as "substances designed to convert the aggregate surface to one that is more easily wetted by asphalt than water".

Historically, hydrated lime has been incorporated in bituminous mixtures as an antistripping agent. The hydrated lime is added in amounts of 0.5 to 3 percent, replacing an equal amount of the mineral filler(minus No. 200 material). Calcium in the lime reacts with silicates in the aggregate (Kennedy, 1984). Two methods have been used to incorporate hydrated lime in bituminous mixtures. One method is to proportion the dry hydrated lime into the heated aggregate. A second method is to prepare a slurry with the lime. The slurry is mixed with the stockpile aggregates and left to condition. After a period of conditioning the stockpile is reworked and then proportioned into the bituminous plant.

Liquid chemical antistripping agents have also been used in bituminous mixtures. Their function is to improve adhesion between the asphalt film and aggregate. A number of such products are available. The liquid chemical antistripping agents are proportioned into the liquid bitumen. Results presented by Tunnicliff and Root (1984) indicated that chemical antistripping additives improved antistripping performance when added in amounts of 0.5 to 1.0 percent. No correction is made in the bitumen content for the amount of agent. A field performance evaluation of antistripping additives has been conducted by Tunnicliff (1997) including laboratory 
tests and field condition surveys. Eight of nine additives successfully reduced the potential for stripping.

\subsection{Laboratory Moisture Susceptibility Tests}

A number of tests are used to evaluate moisture susceptibility of bituminous mixtures (White, 1987). In addition to AASHTO T-283 these tests are detailed in the following:

- NCHRP Report 192 (Lottman).

- NCHRP Report 274 (Modified Lottman).

- ASTM D 1075-81 (AASHTO T 165-82), "Effect of Water on Cohesion of Compacted Bituminous Mixtures".

- ASTM D 1664-80 (AASHTO T 182-82), "Coating and Stripping of BituminousAggregate Mixtures”.

- MIL-STD-620, Immersion-Compression Test.

Some of these tests are based on subjective evaluation of results. In general, the tests have a tenuous correlation with actual field performance. These tests are designed to capture the effects that cause stripping by addressing different modes of failure. Because of their low reliability, up to now, none of the tests have been adopted nationwide. It is important to have an effective test to objectively evaluate the stripping potential of bituminous mixtures and ensure they can resist various performance factors, i.e. heat, moisture, and moving load. 


\subsubsection{Immersion - Compression Test}

In the Immersion-Compression Test (ASTM D 1075) the strength of compacted bituminous mixes is measured before and after moisture conditioning. The test involves applying a compressive load to the flat surfaces of the core (i.e. parallel to the axis of the core as a right cylinder). Six specimens are prepared and are separated into two groups of three specimens so that the average bulk specific gravity of both groups are approximately equal. One set of specimens is conditioned in a $50^{\circ} \mathrm{C}\left(120^{\circ} \mathrm{F}\right)$ water bath for four days and tested in compression at $25^{\circ} \mathrm{C}\left(77^{0} \mathrm{~F}\right)$. The unconditioned group is tested dry at $25^{\circ} \mathrm{C}$. The average compressive strength of each group and an Index of Retained Strength (IRS) are calculated. The asphalt Institute (1981) recommends that an IRS of 75 percent of greater be used as the acceptance/rejection criterion for the test.

Scheroman, et al. (1986) found that some antistripping agents can significantly increase the dry/unconditioned compressive strength of the samples. This results in a lower IRS ratio even though the wet/conditioned compressive strengths are satisfactory. Any test based on a relative wet/dry ratio can produce similar results.

\subsubsection{Indirect Tension Test}

The Indirect Tension Test involves determining the tensile strength of cylindrical specimens by using a diametrical compression test at a specified loading rate and temperature (Lottman, 1978). Like the immersion-compression test, the result is 
based on a relative wet/dry retained tensile strength ratio (TSR). The moisture conditioning includes a vacuum saturation and a single freeze-plus-soak cycle ( -18 to $60^{\circ} \mathrm{C}$ ). Lottman recommends a TSR of 70 percent or larger to distinguish between moisture susceptible mixtures and moisture resistant mixtures.

This test method has been criticized as being too severe with regard to moisture conditioning (Tunnicliff and Root, 1982). This appears to be a procedural matter rather than a problem inherent in the test method. Tunnicliff and Root also recommend that moisture conditioning could be modified to match the actual climatic conditions.

McDaniel (1990), conducted a preliminary study to determine if the RootTunnicliff (Modified Lottman) test (1984) would be effective in evaluating stripping potential of mixes. The TSR results were highly variable. One aggregate in the study varied widely having the highest as well as the lowest values. According to McDaniel (1990), with further refinement, the test recommended by Lottman may provide quantitative correlation of moisture damage to the field performance of bituminous mixes.

\subsubsection{Texas Freeze-Thaw Pedestal Test}

This test method evaluates the moisture susceptibility of an bituminous mixture by determining the number of freeze-thaw cycles that a specimen can survive before cracking (Kennedy, et al., 1982). It uses a compacted cylindrical specimen, composed of a uniformly-sized fraction of aggregate, usually passing the $850 \mu \mathrm{m}$ (No. 20) sieve 
and retained on the $500 \mu \mathrm{m}$ (No. 35) or $425 \mu \mathrm{m}$ (No. 40), and 2 percent more asphalt than proposed for the job mix. The compacted specimen is sealed in a jar and subjected to freeze-thaw cycles $\left(-23.3^{\circ} \mathrm{C}\right.$ to $\left.60^{\circ} \mathrm{C}\right)$ until cracks can be observed on the surface of the specimen. Kennedy, et al. (1982) concluded that the dividing line between stripping-prone and stripping-resistant mixtures lies between 10 and 20 cycles to failure.

Scheroman, et al. (1986) indicated that the Texas Freeze-Thaw Pedestal Test primarily measures the cohesion or strength of the asphalt cement film itself rather than the adhesion of the asphalt cement to the surface of the aggregate. Bolzan (1989) suggested that it is necessary to modify the Freeze-Thaw Pedestal Test with a mechanical based procedure to simulate the traffic effects on the asphalt-aggregate bond.

\subsection{Laboratory Accelerated Wheel Tracking Tests}

There is increasing interest in using a small-scale wheel tracking device to evaluate the performance of bituminous mixtures. Some of the wheel tracking devices have already been used to evaluate pavement performance (Williams, 1996). Those include:

- Laboratoire Central des Ponts et Chaussees (LCPC) French Rutting Tester

- Georgia Loaded Wheel Tester (GLWT)

- Hamburg Steel Wheel Tracking Device (HSWT) 
Their features and test conditions are shown in Table 2.2 to 2.4. These equipments provide a test method to evaluate the performance of bituminous mixtures. This is a very different approach than those currently used by most state highway agencies.

Aschenbrener, et al. (1992), indicated that wheel track testing requires 20 to 30 minutes to compact and approximately 6 to 9 hours to test one sample. They also describe laboratory wheel tracking tests as "torture tests".

According to Aschenbrener, et al. (1992), different criteria are used with each device to evaluate mixture performance. A successful test for the French Rut Tester is one with a rut depth that is less than $10 \%$ of the slab thickness after 30,000 cycles. The test criteria for the GLWT is a rut depth of $7.6 \mathrm{~mm}$ after 8,000 cycles. And, the criteria for the HSWT is a $4 \mathrm{~mm}$ rut depth after 20,000 cycles. Up to date, no comparisons of equivalency between the different test apparatus have been report (Williams, 1996).

Aschenbrener and Currier (1993) recommended that the test temperature for the Hamburg Wheel Tracking Device should relate to the temperature the pavement will experience. Table 2.5. lists recommended testing temperature as well as corresponding performance grade (PG) asphalt recommended by SHRP. They also recommended the air void contents on testing samples should be about $6 \pm 1 \%$ air voids because the stripping inflection point is not significantly influenced by the air void content in this range. Or, no control is maintained on air void content of the specimen, replicate samples should be tested. 
Table 2.1 Tire Pressure Survey Summary (Okamoto and Packard, 1989)

\begin{tabular}{|c|c|c|c|c|c|c|c|c|}
\hline $\begin{array}{c}\text { State } \\
\text { (Year) }\end{array}$ & $\begin{array}{l}\text { No.of } \\
\text { Vehicles }\end{array}$ & $\begin{array}{l}\text { Percent } \\
\text { Radial } \\
\text { Tires } \\
\end{array}$ & $\begin{array}{l}\text { Radials } \\
\text { Average } \\
\text { Psi }^{(6)} \\
\end{array}$ & $\begin{array}{l}\text { Radials } \\
\text { S.D. }{ }^{(7)} \\
\text { Psi }^{(6)} \\
\end{array}$ & $\begin{array}{l}\text { Bias Ply } \\
\text { Average } \\
\mathrm{Psi}^{(6)}\end{array}$ & $\begin{array}{l}\text { Bias ply } \\
\text { S.D. } \\
\text { Psi }^{(6)}\end{array}$ & $\begin{array}{l}\text { Overall } \\
\text { Average } \\
\text { Psi }^{(6)}\end{array}$ & $\begin{array}{l}\text { Overall } \\
\text { S.D. }{ }^{(7)} \text {, } \\
\text { Psi }^{(6)}\end{array}$ \\
\hline $\begin{array}{l}\text { Illinois }^{(1)} \\
(1984)\end{array}$ & 36 & - & - & - & - & - & 96 & 11 \\
\hline $\begin{array}{l}\text { Montana } \\
\text { (1984) }\end{array}$ & - & - & 105 & - & 84 & - & - & - \\
\hline $\begin{array}{l}\text { Florida }{ }^{(2)} \\
\text { (1985) }\end{array}$ & - & - & 103 & 11 & 88 & 12 & 96 & 11 \\
\hline $\begin{array}{l}\text { Kentucky }^{(3)} \\
(1985)\end{array}$ & 59 & 74 & 105 & 11 & 90 & 10 & 103 & 13 \\
\hline $\begin{array}{l}\text { Texas }^{(4)} \\
(1986)\end{array}$ & 1033 & 71 & 98 & 14 & 85 & 15 & 94 & 15 \\
\hline $\begin{array}{l}\text { Arizona } \\
\text { (1986) }\end{array}$ & 350 & 91 & 103 & 11 & 88 & 11 & 102 & 12 \\
\hline $\begin{array}{l}\text { Oregon } \\
(1986)\end{array}$ & - & - & 102 & - & 82 & - & - & - \\
\hline $\begin{array}{l}\text { Nationwide } \\
\text { (5) }(1987)\end{array}$ & 1008 & - & - & - & - & - & 97 & 14 \\
\hline
\end{tabular}

1. Rear trailer axle only.

2. Average of steering and non-steering axle statistics for three sites.

3. Standard deviation estimated from grouped data.

4. AASHTO truck classification 3-S2.

5. Statistics estimated from grouped data.

6. $1 \mathrm{psi}=6.895 \mathrm{kPa}$.

7. S.D. $=$ Standard Deviation 
Table 2.2 Test Parameters of the LCPC French Rut Tester (Williams, 1996)

\begin{tabular}{|l|l|}
\hline Parameter & Condition \\
\hline No. of specimens tested simultaneously & Two. \\
\hline Range of test temperature & $35-60^{\circ} \mathrm{C}$. \\
\hline Environmental condition & Dry cycle testing only. \\
\hline Maximum specimen size & Up to $100 \times 160 \times 500 \mathrm{~mm}$. \\
\hline Wheel types & Pneumatic only ( up to $690 \mathrm{kPa}$ tire pressure). \\
\hline Wheel size & 400 mm diameter, $90 \mathrm{~mm}$ wide. \\
\hline Load & Up to $5000 \mathrm{~N}$. \\
\hline Frequency of measurement & $\begin{array}{l}\text { User designated by setting a mechanical counter after } \\
\text { every rut depth measurements. }\end{array}$ \\
\hline Rut depth measurement location & $\begin{array}{l}\text { Three locations centered } \pm 90 \mathrm{~mm} \text { about center } \\
\text { of specimens. }\end{array}$ \\
\hline Method of rut depth measurement & Manually placing "fingers" at new place of measurement. \\
\hline Acquisition of data & Automatic. \\
\hline Wheel speed & 1.6 m/s. \\
\hline Wheel wander & Wheel wander is not an option. \\
\hline & \\
\hline
\end{tabular}


Table 2.3 Test Parameters of the Georgia Loaded Wheel Tester (Williams, 1996)

\begin{tabular}{|c|c|}
\hline Parameter & Condition \\
\hline No. of specimens tested simultaneously & Three. \\
\hline Range of test temperature & $40-60^{\circ} \mathrm{C}$ \\
\hline Environmental condition & Dry cycle testing only. \\
\hline Maximum specimen size & Up to $17 \times 125 \times 300 \mathrm{~mm}$. \\
\hline Wheel types & $\begin{array}{l}\text { Aluminum wheel on a pressurized hose } \\
(700 \mathrm{kPa} \text { hose pressure })\end{array}$ \\
\hline Wheel size & Not available \\
\hline Load & Up to $445 \mathrm{~N}$. \\
\hline Frequency of measurement & $\begin{array}{l}\text { User designated by setting a mechanical counter after } \\
\text { every rut depth measurements. }\end{array}$ \\
\hline Rut depth measurement location & $\begin{array}{l}\text { Three locations centered } \pm 50 \mathrm{~mm} \text { about center } \\
\text { of specimens. }\end{array}$ \\
\hline Method of rut depth measurement & $\begin{array}{l}\text { Manually adjusting a sliding table at place of } \\
\text { measurement. }\end{array}$ \\
\hline Acquisition of data & Automatic. \\
\hline Wheel speed & $0.6 \mathrm{~m} / \mathrm{s}$ \\
\hline Wheel wander & Wheel wander is not an option. \\
\hline
\end{tabular}


Table 2.4. Test Parameters of the Hamburg Steel Wheel Tracking Device (Williams, 1996)

\begin{tabular}{|l|l|}
\hline Parameter & Condition \\
\hline No. of specimens tested simultaneously & Two. \\
\hline Range of test temperature & Room Temperature $-60^{\circ} \mathrm{C}$. \\
\hline Environmental condition & Wet cycle testing only. \\
\hline Maximum specimen size & Up to $175 \times 305 \times 305 \mathrm{~mm}$. \\
\hline Wheel types & Steel wheel, $47 \mathrm{~mm}$ wide. \\
\hline Wheel size & $203.5 \mathrm{~mm}$. \\
\hline Load & Up to $697 \mathrm{~N}$. \\
\hline Frequency of measurement & Every 250 wheel passes. \\
\hline Rut depth measurement location & Center of specimen. \\
\hline Method of rut depth measurement & Automatic by linear voltage displacement transducers. \\
\hline Acquisition of data & Automatic. \\
\hline Wheel speed & Sinusoidal with a maximum of $0.33 \mathrm{~m} / \mathrm{s}$ at the center \\
of sample.
\end{tabular}


Table 2.5 Recommended Testing Temperature for the Hamburg Wheel Tracking Device, (Aschenbrener and Currier, 1993)

\begin{tabular}{|c|c|c|c|c|}
\hline $\begin{array}{l}\text { High } \\
\text { Temperature. } \\
\text { Category }\end{array}$ & $\begin{array}{l}\text { Appro. } \\
\text { Highest } \\
\text { Average 7-Day } \\
\text { Air } \\
\text { Temperature }\end{array}$ & $\begin{array}{l}\text { High Temp. } \\
\text { Performance } \\
\text { Grade (PG) }{ }^{\circ} \mathrm{C}\end{array}$ & $\begin{array}{l}\text { Asphalt Cement } \\
\text { Grade Meeting } \\
\text { the High Temp. } \\
\mathrm{PG}\end{array}$ & $\begin{array}{l}\text { Recommended } \\
\text { Test Temp. for } \\
\text { the Hamburg } \\
\text { Device }\end{array}$ \\
\hline Very Cool & $<27^{0} \mathrm{C}$ & 46 & N/A & $35^{\circ} \mathrm{C}$ \\
\hline Cool & 27 to $31^{0} \mathrm{C}$ & 52 & AC-5 & $40^{0} \mathrm{C}$ \\
\hline Moderate & 32 to $36^{\circ} \mathrm{C}$ & 58 & AC-10 & $45^{\circ} \mathrm{C}$ \\
\hline Hot & $>36^{\circ} \mathrm{C}$ & 64 & AC-20 & $50^{\circ} \mathrm{C}$ \\
\hline Very Hot & $*$ & 76 & AC-20P & $55^{\circ} \mathrm{C}$ \\
\hline
\end{tabular}

* No pavements in Colorado are at this temperature. 


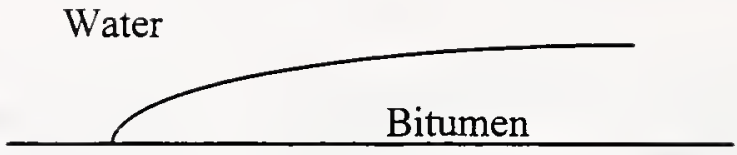

Aggregate

Figure 2.1 Schematic representation of Aggregate-asphalt interface model (Gzemski, et al., 1968)

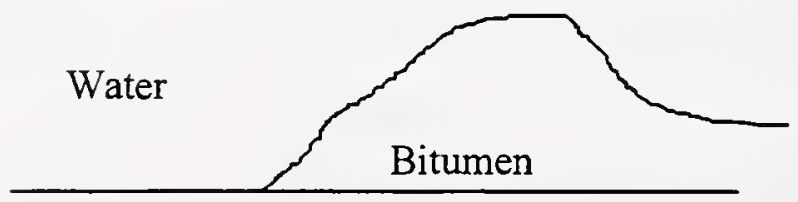

Aggregate

Figure 2.2 Schematic representation of "roll-back" interface model (Gzemski, et al., 1968) 


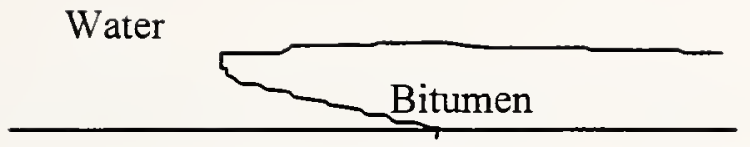

Aggregate

Figure 2.3 Schematic representation of "lift-off" interface model (Gzemski, et al., 1968) 


\section{CHAPTER 3 MATERIALS AND EXPERIMENTAL DESIGNS}

\subsection{Introduction}

This chapter described materials, mix design results and experimental designs of the study. Different mixture types (i.e. surface, binder, and base) and aggregates commonly utilized in Indiana were included. Those mixes were also treated with hydrated lime and a liquid antistripping agent.

\subsection{Materials}

\subsubsection{Asphalt and Aggregate}

The asphalt cement incorporated in this study was an AC-20 (PG 64-22) from AMOCO, Whiting, Indiana. Table 3.1. lists test results for the asphalt and the INDOT (INDOT, 1995) asphalt specifications. The aggregate selection is based on resource availability in Indiana and represent a wide range of aggregate types. Aggregate characteristics and sources are listed in Tables 3.2. and 3.3, respectively. 


\subsubsection{Asphalt Mixtures}

Seven asphalt mixtures were chosen for the study. They included three \#11 surface mixes, three $\# 8$ binder mixes, and one $\# 5 \mathrm{C}$ coarse gradation base mix. The difference between these mixtures is their nominal maximum aggregate size and gradation requirements. Fig. 3.1 through Fig. 3.3 show the gradations for the surface, binder, and base mixtures, respectively.

Mix designs were conducted using a seventy-five blow Marshall hand-hammer compaction effort. According to INDOT's criteria, optimum asphalt contents were selected solely on six percent air voids and to be within a range of acceptable asphalt content for different types of mixtures (INDOT, 1995). Otherwise, the mix design followed the procedure described in the Asphalt Institute Manual, MS-2 (Asphalt Institute, 1995). INDOT mix design criteria also includes a minimum stability of $545 \mathrm{Kg}$, and a maximum flow of $4 \mathrm{~mm}(0.16 \mathrm{in}$.$) . Voids in the mineral aggregate (VMA)$ requirements are a minimum of $15 \%, 13 \%$, and $12 \%$ for the surface, binder, and base mixes, respectively. Summaries of mix design results are listed in Table 3.4. and Table 3.5. Each mix included $2 \%$ mineral filler to represent fines expected to be generated in the mixture production.

\subsubsection{Additive/Modifiers}

Two anti-stripping additives were evaluated to examine their effects on moisture susceptibility of the mixes. A liquid anti-stripping additive, Pave-Bond Special, was used 
as supplied by Morton International. The liquid antistripping agent was proportioned into the liquid asphalt (AC-20) at a $0.5 \%$ dosage rate. No correction was made in the bitumen content for the amount of agent. Hydrated lime, obtained from a local hardware store, was also utilized. Two percent of hydrated lime was incorporated into the bituminous mixtures, replacing an equal amount of the mineral filler(minus No. 200 sieve).

\subsection{Experimental Designs}

From the literature review and preliminary research, the following factors were identified as significant for determining stripping/rutting potential of bituminous mixtures.

1. Mixture gradation and maximum aggregate size

2. Coarse crushed aggregate

3. Fine aggregate angularity

4. Aggregate type

5. Anti-stripping agent

In this study, the experimental design was focused on different types of aggregate and mix gradations. Most of the mixtures included an uncrushed natural sand as the fine aggregate source to emphasized rutting/stripping potential. The effect of anti-stripping agents can be easily examined if the mix is susceptible to stripping. As noted above, asphalt content for each mix was based on the Indiana mix design criteria and no 
adjustment was made for the anti-stripping additive. Variation of asphalt binder was not included in this study.

Three levels of maximum aggregate sizes were included in this study, surface, binder, and open graded base course. These three levels were selected based on gradation requirements for HMA in the INDOT Specifications (INDOT, 1995). Each level contained three different types of coarse aggregate, except the open graded base course. Only limestone aggregate was utilized in the open graded base mixture because of limited availability of large aggregate.

Since AASHTO T-283 (AASHTO, 1995) has been recognized as a standard laboratory test, material variations and anti-stripping agents were the variables considered in the experimental designs. The matrix of tests in this experiment is shown in Table 3.6.

Table 3.7. and Table 3.8 show the matrix of tests for the laboratory wheel track tests. Seven different asphalt mixtures were tested to evaluate their rutting/stripping potential. Three of the mixes were also utilized to evaluate the effects of anti-stripping agents. Triplicate samples were prepared and tested to include the effect of sample variation. Two surface mixtures (dolomite and limestone) were tested over a range of temperature from room $\left(25^{\circ} \mathrm{C}\right)$ to $60^{\circ} \mathrm{C}$. These tests were conducted to determine the effect of temperature on the asphalt concrete mixture rutting/stripping potential. These two mixtures were selected because the aggregates are widely used in Indiana.

The goal of the experiments was to identify the influence of test variables on the results from the existing laboratory stripping test (AASHTO T-283) as well as the 
laboratory wheel track test. It is important to evaluate how those variables change the performance of the asphalt mixture and to develop a standard laboratory procedure for the wheel track test. 
Table 3.1 Binder Properties

\begin{tabular}{|l|c|c|}
\hline \multicolumn{1}{|c|}{ Binder Properties } & Test Result & $\begin{array}{c}\text { INDOT Specifications, } \\
902.01(\mathrm{~g})-95\end{array}$ \\
\hline Specific Gravity @ $25^{\circ} \mathrm{C}$ & 1.036 & N/A \\
\hline Flash Point (Cleveland), ${ }^{0} \mathrm{C}$ & 288 & 232 minimum \\
\hline Kinematic Viscosity @ $135^{0} \mathrm{C}, \mathrm{cSt}$ & 393 & 300 minimum \\
\hline $\begin{array}{l}\text { Absolute Viscosity @ } 60^{\circ} \mathrm{C} \\
(300 \mathrm{~mm} \text { Hg vacuum), P }\end{array}$ & 2165 & $.1600-2500$ \\
\hline Penetration @ $25^{0} \mathrm{C}, 100 \mathrm{~g}, 5 \mathrm{sec}$ & 65 & $50-110$ \\
\hline Solubility, $\%$ & 99.9 & 99.0 minimum \\
\hline Viscosity @ 60 C, P & 5293 & 8000 maximum \\
\hline Ductility @ 25 ${ }^{\circ} \mathrm{C}, 5 \mathrm{~cm} / \mathrm{min}, \mathrm{cm}$ & 110 & 40 minimum \\
\hline Lost on Heat (T. F. O. T.) & 0.25 & N/A \\
\hline
\end{tabular}


Table 3.2 Coarse Aggregate Stockpiles

\begin{tabular}{|l|c|c|c|c|c|c|c|c|c|}
\hline Agg. Size & \multicolumn{3}{|c|}{$12.5 \mathrm{~mm}$} & $9.5 \mathrm{~mm}$ & \multicolumn{3}{|c|}{$25.0 \mathrm{~mm}$} & $37.5 \mathrm{~mm}$ \\
\hline Agg. Type & Limestone & Dolomite & Slag & Dolomite & Slag & Limestone & Gravel & Limestone \\
\hline Agg. Source & $\begin{array}{c}\text { Rogers, } \\
\text { Kentland, } \\
\text { IN }\end{array}$ & $\begin{array}{c}\text { Charlestown } \\
\text { IN }\end{array}$ & $\begin{array}{c}\text { Gary, } \\
\text { IN }\end{array}$ & $\begin{array}{c}\text { Lockport, } \\
\text { IL }\end{array}$ & $\begin{array}{c}\text { Gary, } \\
\text { IN }\end{array}$ & $\begin{array}{c}\text { Rogers, } \\
\text { Kentland, } \\
\text { IN }\end{array}$ & $\begin{array}{c}\text { W. Lafayette } \\
\text { IN }\end{array}$ & $\begin{array}{c}\text { Delphi } \\
\text { IN }\end{array}$ \\
\hline Sp. Gravity & 2.655 & 2.614 & 2.350 & 2.680 & 2.339 & 2.653 & 2.615 & 2.650 \\
\hline Sieve Size & \multicolumn{7}{|c|}{ Percent Passing by Weight } \\
\hline $37.5 \mathrm{~mm}$ & 100.0 & 100.0 & 100.0 & 100.0 & 100.0 & 100.0 & 100.0 & 100.0 \\
\hline $25.0 \mathrm{~mm}$ & 100.0 & 100.0 & 100.0 & 100.0 & 100.0 & 100.0 & 100.0 & 91.4 \\
\hline $19.0 \mathrm{~mm}$ & 100.0 & 100.0 & 100.0 & 100.0 & 91.0 & 88.0 & 89.0 & 70.8 \\
\hline $12.5 \mathrm{~mm}$ & 100.0 & 100.0 & 100.0 & 100.0 & 55.0 & 48.0 & 53.0 & 38.4 \\
\hline $9.5 \mathrm{~mm}$ & 79.8 & 91.7 & 85.0 & 100.0 & 33.0 & 29.0 & 29.0 & 21.3 \\
\hline $4.75 \mathrm{~mm}$ & 17.0 & 15.7 & 20.0 & 23.0 & 8.0 & 6.0 & 2.0 & 3.3 \\
\hline $2.36 \mathrm{~mm}$ & 1.5 & 6.7 & 3.0 & 6.0 & 5.0 & 1.0 & 1.5 & 1.0 \\
\hline $1.18 \mathrm{~mm}$ & 0.0 & 6.0 & 1.9 & 5.5 & 4.5 & 1.0 & 1.0 & 1.0 \\
\hline $0.6 \mathrm{~mm}$ & 0.0 & 5.8 & 1.5 & 5.0 & 4.0 & 1.0 & 1.0 & 1.0 \\
\hline $0.3 \mathrm{~mm}$ & 0.0 & 5.6 & 1.3 & 4.0 & 3.6 & 1.0 & 0.7 & 1.0 \\
\hline $0.15 \mathrm{~mm}$ & 0.0 & 5.2 & 1.1 & 3.0 & 3.1 & 1.0 & 0.6 & 1.0 \\
\hline $0.075 \mathrm{~mm}$ & 0.0 & 3.9 & 1.0 & 2.0 & 2.6 & 0.5 & 0.3 & 1.0 \\
\hline
\end{tabular}


Table 3.3 Fine Aggregate Stockpiles

\begin{tabular}{|l|c|c|c|c|c|c|}
\hline Agg. Size & \multicolumn{5}{|c|}{$4.75 \mathrm{~mm}$} & \multirow{2}{*}{ Mineral Filler } \\
\cline { 1 - 5 } Agg. Type & Man. Sand & \multicolumn{5}{|c|}{ Natural Sand } \\
\cline { 1 - 5 } & $\begin{array}{c}\text { Rogers, } \\
\text { Agg. Source }\end{array}$ & $\begin{array}{c}\text { Lafayette, } \\
\mathrm{IN}\end{array}$ & $\begin{array}{c}\text { Lafayette, } \\
\mathrm{IN}\end{array}$ & $\begin{array}{c}\text { Evansville, } \\
\mathrm{IN}\end{array}$ & $\begin{array}{c}\text { Hunt Lake, } \\
\mathrm{IN}\end{array}$ & $\begin{array}{c}\text { Swayzee, } \\
\mathrm{IN}\end{array}$ \\
\hline Bulk Sp. Gravity & 2.640 & 2.609 & 2.603 & 2.582 & 2.564 & 2.700 \\
\hline Sieve Size, mm & \multicolumn{7}{|c|}{ Percent Passing } \\
\hline 12.5 & 100.0 & 100.0 & 100.0 & 100.0 & 100.0 & 100.0 \\
\hline 9.5 & 100.0 & 100.0 & 100.0 & 100.0 & 100.0 & 100.0 \\
\hline 4.75 & 100.0 & 100.0 & 100.0 & 99.4 & 96.0 & 100.0 \\
\hline 2.36 & 77.0 & 90.0 & 86.1 & 83.5 & 86.4 & 100.0 \\
\hline 1.18 & 47.3 & 65.0 & 67.6 & 67 & 76.3 & 100.0 \\
\hline 0.6 & 30.7 & 43.0 & 41.6 & 50.2 & 63 & 100.0 \\
\hline 0.3 & 19.7 & 17.0 & 12.1 & 8.4 & 20 & 96.6 \\
\hline 0.15 & 9,7 & 2.0 & 4.1 & 1.1 & 1.8 & 71.3 \\
\hline 0.075 & 4.3 & 0.7 & 1.5 & 0.2 & 0.7 & 21.9 \\
\hline
\end{tabular}


Table 3.4 Percentage of Stockpiles

\begin{tabular}{|l|l|c|c|}
\hline Mixtures & Types of Agg. (Source) & \% in the Mix & \% of Mineral Filler \\
\hline \#11 Limestone & Limestone (Rogers) & 47 & 2 \\
& Natural Sand (W. Lafayette) & 51 & \\
\hline \#11 Dolomite & Dolomite (Charlestown) & 45 & 2 \\
& Natural Sand (Evansville) & 53 & \\
\hline \#11 Slag & Slag (Gary) & 25 & \\
& Dolomite (Lockport) & 25 & \\
& Natural Sand (Hunt Lake) & 48 & \\
\hline \#8 Gravel & Gravel (W.Lafayette) & 74 & \\
& Man. Sand (Rogers) & 23.5 & \\
\hline \#8 Limestone & Limestone (Rogers) & 75.9 & \\
& Natural Sand (Lafayette) & 23 & \\
\hline \#8 Slag & Slag(Gary) & 70 & \\
& Natural Sand(Hunt Lake) & 28 & \\
\hline \#5C Limestone & Limestone (Delphi) & 83 & \\
& Natural (Lafayette) & 15 & \\
\hline
\end{tabular}


Table 3.5 Summary of Marshall Mix Design Results

\begin{tabular}{|l|c|c|c|c|c|}
\hline & $\begin{array}{c}\text { Rice Spec. } \\
\text { Gravity }\end{array}$ & $\begin{array}{c}\text { Stability } \\
(\mathrm{Kg})\end{array}$ & $\begin{array}{c}\text { Flow } \\
(\mathrm{mm})\end{array}$ & $\begin{array}{c}\text { VMA } \\
\%\end{array}$ & $\begin{array}{c}\text { Optimum Asphalt } \\
\text { Content, \% }\end{array}$ \\
\hline$\# 11 \mathrm{DCM}^{(1)}$ & 2.426 & 726 & 2.2 & 17.5 & 6.3 \\
\hline$\# 11 \mathrm{LCM}^{(2)}$ & 2.498 & 859 & 2.3 & 16.3 & 5.2 \\
\hline$\# 11 \mathrm{SCM}^{(3)}$ & 2.420 & 1453 & 2.3 & 16.5 & 6.2 \\
\hline$\# 8 \mathrm{GCM}^{(4)}$ & 2.521 & 1308 & 2.6 & 14.5 & 4.1 \\
\hline$\# 8 \mathrm{LCM}^{(5)}$ & 2.584 & 953 & 2.9 & 14.5 & 4.8 \\
\hline$\# 8 \mathrm{SCM}^{(6)}$ & 2.343 & 1875 & 2.3 & 13.2 & 4.3 \\
\hline$\# 5 \mathrm{C} \mathrm{LCM}^{(7)}$ & 2.568 & 1410 & 3.1 & 12.4 & 4.0 \\
\hline
\end{tabular}

(1) \#11 DCM :\#11 dolomite surface mixture

(2) \#11 LCM :\#11 limestone surface mixture

(3) \#11 SCM :\#11 slag surface mixture

(4) \#8 GCM :\#8 gravel binder mixture

(5) \#8 LCM :\#8 limestone binder mixture

(6) \#8 SCM :\#8 slag binder mixture

(7) \#5C LCM :\#5C limestone base mixture 
Table 3.6 Experimental Matrix for AASHTO T283 Tests

\begin{tabular}{|c|c|c|c|c|}
\hline \multirow{4}{*}{$\begin{array}{c}\text { Mixture } \\
\text { Type }\end{array}$} & $\begin{array}{c}\text { Aggregate } \\
\text { Type }\end{array}$ & Control & Hydrated Lime & Liquid agent \\
\cline { 3 - 5 } & Dolomite & $\mathrm{X}$ & $\mathrm{X}$ & $\mathrm{X}$ \\
\cline { 2 - 5 } & $\mathrm{Slag}$ & $\mathrm{X}$ & $\mathrm{X}$ & $\mathrm{X}$ \\
\hline \multirow{3}{*}{ Binder Mixtures } & Limestone & $\mathrm{X}$ & $\mathrm{X}$ & $\mathrm{X}$ \\
\cline { 2 - 5 } & Dolomite & $\mathrm{X}$ & $\mathrm{X}$ & $\mathrm{X}$ \\
\cline { 2 - 5 } & Slag & $\mathrm{X}$ & $\mathrm{X}$ & $\mathrm{X}$ \\
\cline { 2 - 5 } & Limestone & $\mathrm{X}$ & $\mathrm{X}$ & $\mathrm{X}$ \\
\hline Base Mixture & Limestone & $\mathrm{X}$ & $\mathrm{X}$ & $\mathrm{X}$ \\
\hline
\end{tabular}


Table 3.7 Experimental Matrix for Laboratory Wheel Tests to Determine the Influence of Aggregate and Additives/Modifier

\begin{tabular}{|c|c|c|c|c|c|c|c|}
\hline \multirow{3}{*}{ Mixture Type } & \multirow{3}{*}{$\begin{array}{c}\text { Aggregate } \\
\text { Type }\end{array}$} & \multicolumn{6}{|c|}{ Additives/Modifier } \\
\hline & & \multicolumn{2}{|c|}{ Control } & \multicolumn{2}{|c|}{ Hydrated Lime } & \multicolumn{2}{|c|}{ Liquid agent } \\
\hline & & Wet & Dry & Wet & Dry & Wet & Dry \\
\hline \multirow{3}{*}{ Surface Mixtures } & Dolomite & $\mathrm{XXX}$ & $\mathrm{XXX}$ & $\overline{X X X}$ & $\mathrm{XXX}$ & $\mathrm{XXX}$ & $\mathrm{XXX}$ \\
\hline & Slag & $\mathrm{XXX}$ & $\mathrm{XXX}$ & & & & \\
\hline & Limestone & $\mathrm{XXX}$ & $\mathrm{XXX}$ & & & & \\
\hline \multirow{3}{*}{ Binder Mixtures } & Gravel & $\mathrm{XXX}$ & $\mathrm{XXX}$ & $\mathrm{XXX}$ & $\mathrm{XXX}$ & $\mathrm{XXX}$ & $\mathrm{XXX}$ \\
\hline & Slag & $\mathrm{XXX}$ & $\mathrm{XXX}$ & & & & \\
\hline & Limestone & $\mathrm{XXX}$ & $\mathrm{XXX}$ & & & & \\
\hline Base Mixture & Limestone & $\mathrm{XXX}$ & $\mathrm{XXX}$ & $\mathrm{XXX}$ & $\mathrm{XXX}$ & $\mathrm{XXX}$ & $\mathrm{XXX}$ \\
\hline
\end{tabular}

Table 3.8 Experimental Matrix for Laboratory Wheel Tests to Determine the Influence of Temperature

\begin{tabular}{|c|c|c|c|c|c|c|c|c|c|c|}
\hline \multirow{3}{*}{$\begin{array}{c}\text { Aggregate } \\
\text { Type }\end{array}$} & \multicolumn{9}{|c|}{ Test Temperature $\left({ }^{0} \mathrm{C}\right)$} \\
\cline { 2 - 10 } & \multicolumn{2}{|c|}{60} & \multicolumn{2}{|c|}{50} & \multicolumn{2}{|c|}{40} & \multicolumn{2}{|c|}{30} & \multicolumn{2}{|c|}{25} \\
\cline { 2 - 10 } & Wet & Dry & Wet & Dry & Wet & Dry & Wet & Dry & Wet & Dry \\
\hline Dolomite & $\mathrm{XXX}$ & $\mathrm{XXX}$ & $\mathrm{XXX}$ & $\mathrm{XXX}$ & $\mathrm{XXX}$ & $\mathrm{XXX}$ & $\mathrm{XXX}$ & $\mathrm{XXX}$ & $\mathrm{XXX}$ & $\mathrm{XXX}$ \\
\hline Limestone & $\mathrm{XXX}$ & $\mathrm{XXX}$ & $\mathrm{XXX}$ & $\mathrm{XXX}$ & $\mathrm{XXX}$ & $\mathrm{XXX}$ & $\mathrm{XXX}$ & $\mathrm{XXX}$ & $\mathrm{XXX}$ & $\mathrm{XXX}$ \\
\hline
\end{tabular}




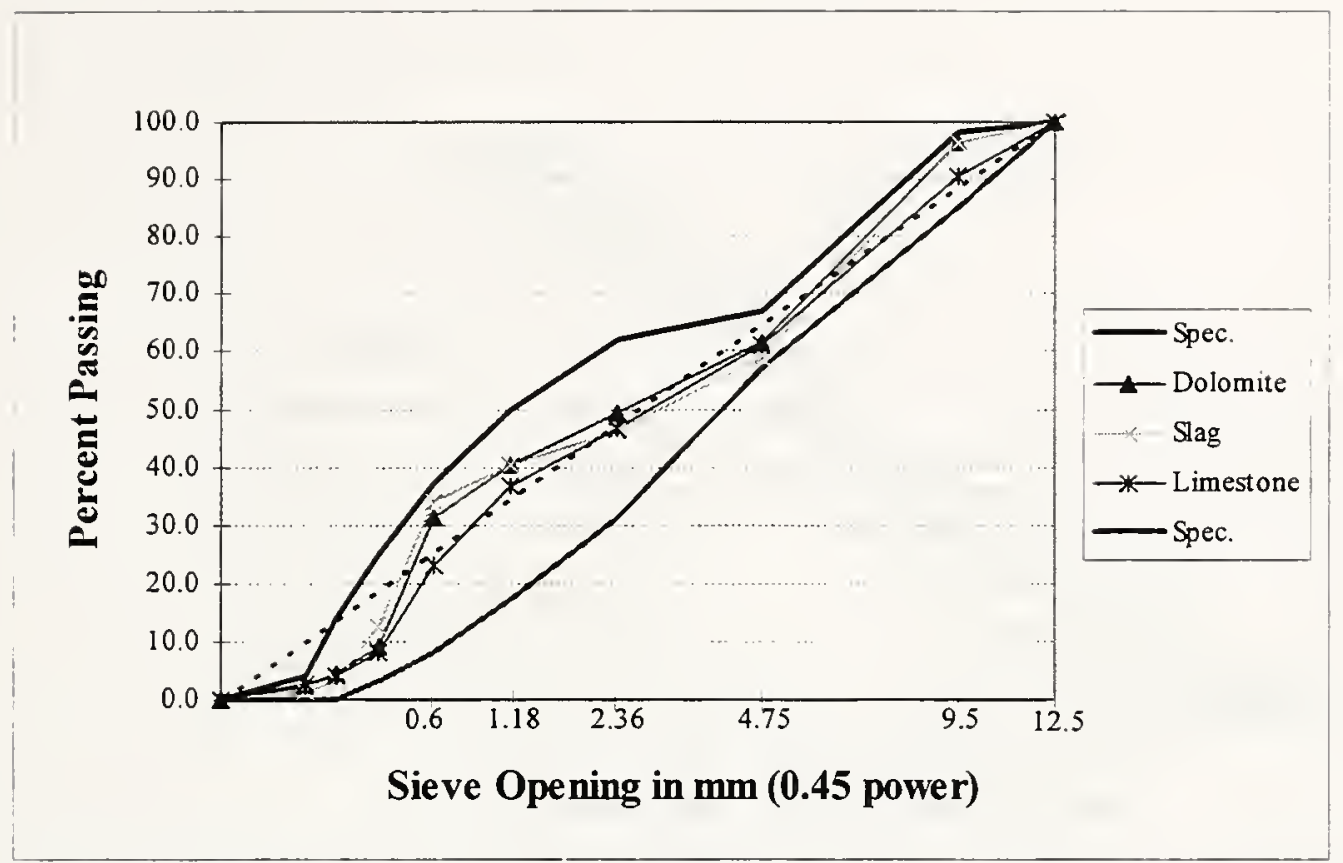

* Spec.: Indiana Gradation Specifications (INDOT, 1995)

Figure 3.1 \#1 1 Surface Mixture Gradations 


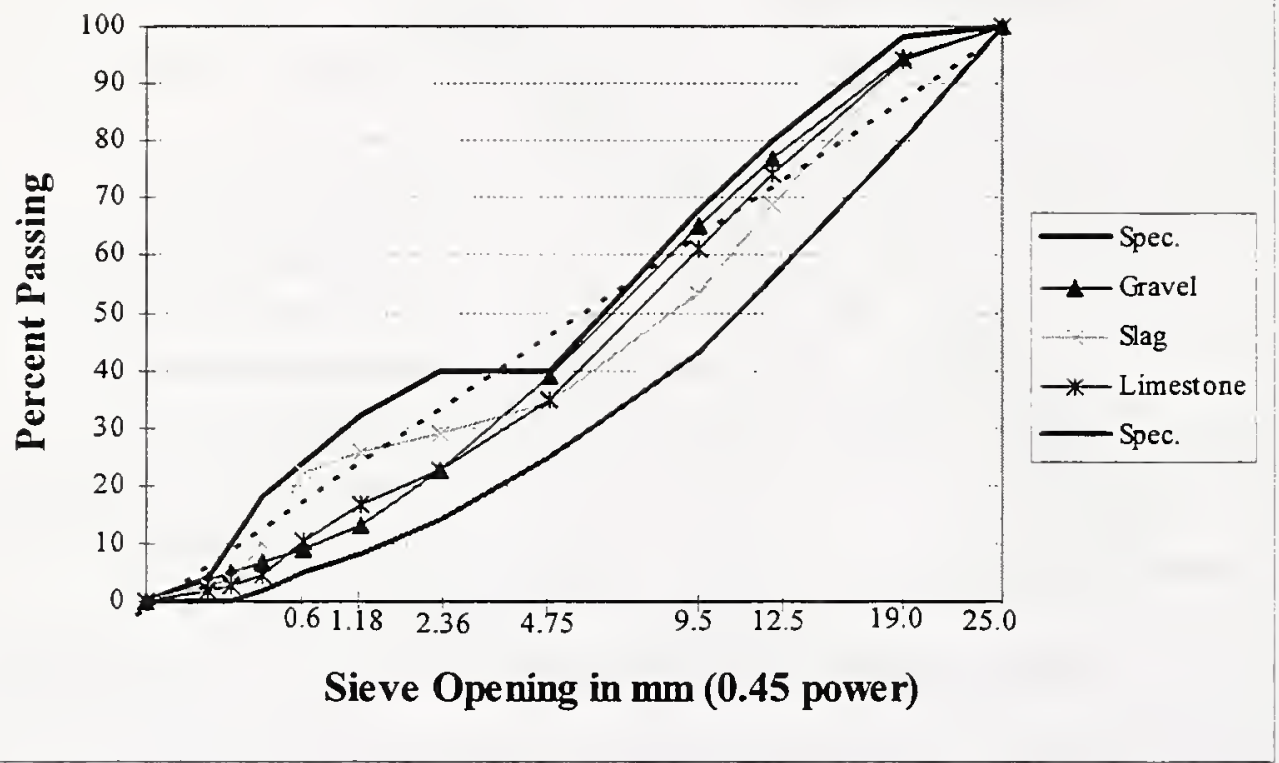

* Spec.: Indiana Gradation Specifications (INDOT, 1995)

Figure 3.2 \#8 Binder Mixture Gradations 


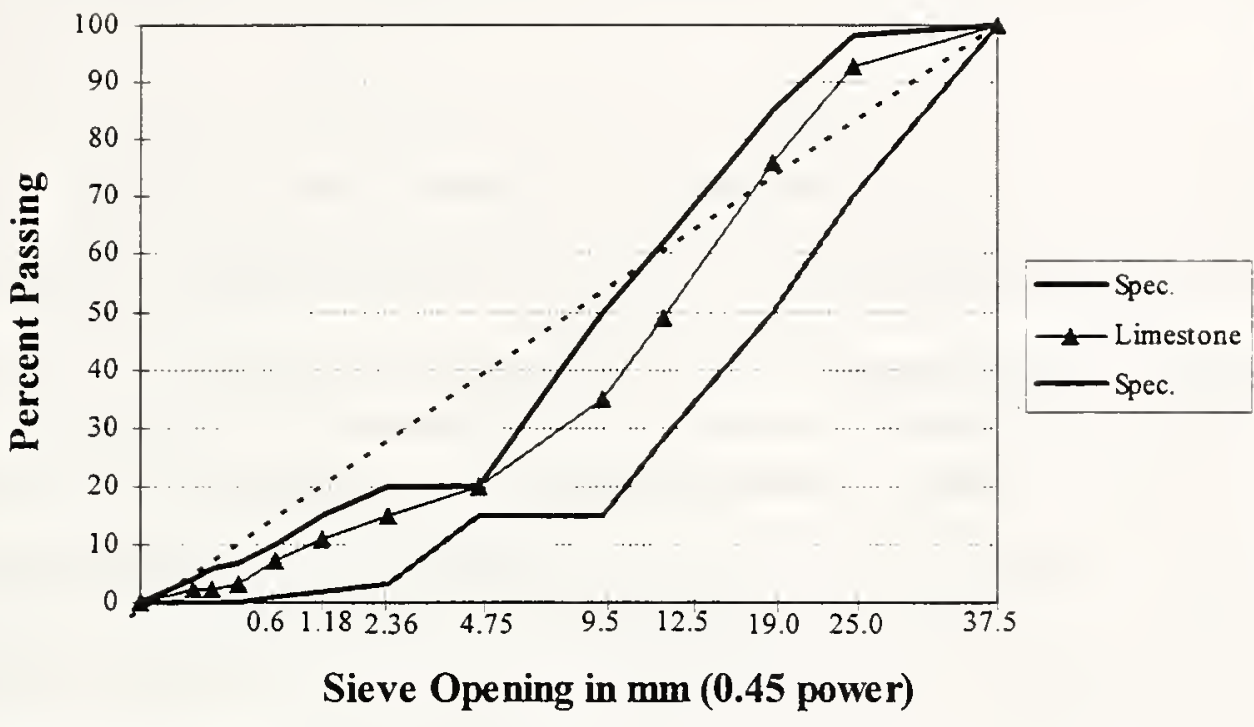

* Spec.: Indiana Gradation Specifications (INDOT, 1995)

Figure 3.3 \#5C Open Gradation Base Mixture Gradations 


\section{CHAPTER 4 LABORATORY MOISTURE SENSITIVITY TESTS}

There are several laboratory tests that have been used for evaluating moisture sensitivity of asphalt mixtures. Currently mixture stripping potential in the Superpave system is evaluated with AASHTO T-283 (AASHTO, 1995). AASHTO T-283, "Standard Method of Test for Resistance of Compacted Bituminous Mixtures to Moisture Induced Damage," was conducted in this study not only to determine its applicability but also as a benchmark test method. The general procedures and results of the tests are discussed in the following sections.

\subsection{Specimen Preparations for AASHTO T-283 Tests}

Currently sample preparation in AASHTO T-283 are prepared using Marshall impact compaction. In order to determine the compaction effort to achieve the required 7 $\pm 1 \%$ air voids specimens were compacted at the design asphalt content. Selection of the design asphalt content was described in Chapter Three. Two specimens were subjected to 40 and 60 blow compactive efforts, respectively. Bulk specific gravity (BSG) was determined (ASTM D2726) after an overnight room temperature curing. An air voids vs. 
No. of blows relationship was utilized to establish to estimate the compactive effort to achieve the target $(7 \pm 1 \%)$ air void content.

After the compactive effort was determined, six $1200 \mathrm{~g}$ batches were prepared. Subsequently, the asphalt and aggregates were mixed in individual batches and the loose mixtures were put into a $60^{\circ} \mathrm{C}$ oven for 16 hours. The mixes were then heated to $135^{\circ} \mathrm{C}$ for $2 \pm 0.5$ hours. The six batches were compacted with a Marshall manual hand-hammer (Figure 4.1) with the required number of blows to achieve an air voids of $7 \pm 1 \%$. The compacted specimens were store at room temperature for 3 to 4 days before testing. In general, two additional specimens were prepared to insure there would be at least six specimens to satisfy the air voids requirement. The extra samples were used to determine the required time for vacuum saturation.

\subsection{Testing Procedures}

A set of six samples for a mix were separated into two groups of three so that the average air voids of the two groups were equal. One set of three is subjected to cycles of wetting, freezing, thawing and hot water curing. These conditions are utilized to accelerated environmental effects on the asphalt mixture. The wetting involves a 55 to 80 percent saturation by applying 10 to 26 inches $\mathrm{Hg}$ vacuum, followed by at least 16 hours

of freezing in air at $0 \pm 5^{\circ} \mathrm{C}$, soaking in water for $24 \pm 1$ hours at $60 \pm 1^{\circ} \mathrm{C}$, and conditioning in water for two hours at $25 \pm 0.5^{\circ} \mathrm{C}$ before testing. 
The indirect tensile test is conducted on the conditioned and unconditioned set of specimens. Figure 4.2 shows the indirect tensile test apparatus used in this study. The steel loading strips were used to apply a load along the diameter of the specimen. Loading rate was controlled to a vertical deformation of $50.8 \mathrm{~mm}$ per minute. The maximum force was recorded and converted to the tensile strength of the specimen as follows:

$$
S_{t}=\frac{2 P}{\pi t D}
$$

where:

$\mathrm{S}_{\mathrm{t}} \quad=$ tensile strength,

$\mathrm{P} \quad=$ maximum load,

$\mathrm{t}=$ specimen thickness (average of three measurements), and

$\mathrm{D} \quad=$ specimen diameter $(102 \mathrm{~mm})$.

The tensile strength ratio (TSR) is calculated as follows:

$$
T S R=\frac{S_{1}}{S_{2}} \times 100
$$

where:

$\mathrm{S}_{1} \quad=$ average tensile strength of conditioned subset, and

$\mathrm{S}_{2} \quad=$ average tensile strength of dry subset. 


\subsection{Results for AASHTO T-283 Tests}

\subsubsection{Results for Surface Mixtures}

Results from AASHTO T-283 tests for the \#11 Limestone, Slag and Dolomite mixtures are summarized in Table 4.1. to 4.3. The tensile strength ratios (TSR) of the three control mixtures are all below 80 percent (Minimum Superpave TSR). Test results also show that the moisture susceptibility of the three mixtures can be improved to meet the Superpave mix design criteria ( TSR greater than 80 percent ) after addition of antistripping agents.

Comparison of the TSR results for the two antistripping agents indicates that hydrated lime is more effective than the liquid chemical antistripping agent in improving the moisture susceptibly of mixtures. Figure 4.3 to Figure 4.5 show the indirect tensile strength for \#11 dolomite, limestone, and slag mix, respectively. Although the TSR is controlled by both dry and wet conditioning tensile strength, hydrated lime can still produce a slightly higher tensile strength for the mixtures after moisture conditioning.

\subsubsection{Results for Binder Mixtures}

Results from AASHTO T-283 tests are summarized in Table 4.4 to Table 4.6. The tensile strength ratio (TSR) of three control mixtures are all below 80 percent (Minimum Superpave TSR). In general, test results show that the TSR of the three 
control mixtures can be increased to meet the Superpave mix design criteria ( TSR greater than 80 percent ) with addition of hydrated lime. The exception is gravel mixtures.

Comparison of the results for the \#8 gravel binder mixtures indicates that the two anti-stripping agents (chemical and hydrated lime) had no effect on the ITS values with the control mix had the highest TSR value among three $\# 8$ binder mixtures. Figure 4.6 to Figure 4.8 show the indirect tensile strengths for \#8 gravel, limestone, and slag mix, respectively. The $\# 8$ gravel mixtures used in this study were the only mixtures containing $100 \%$ crushed sand. Test results revealed that fine aggregates could be an major factor in the loss of adhesion of asphalt film. A proper portion of crushed sand in the mixture may by itself help reduce moisture damage.

\subsubsection{Results for Base Mixtures}

Results from AASHTO T-283 tests on the limestone base mixture are summarized in Table 4.7. The tensile strength ratios (TSR) of the control mixtures are below 80 percent (Minimum Superpave TSR). Test results also show that TSR of the mixtures can be increased by the antistripping agents. However, the TSRs are still below the minimum Superpave mix design criteria (TSR greater than 80 percent).

The ITS results for the $\# 5 C$ Limestone base mix are also shown in Table 4.7. Figure 4.9 shows the indirect tensile strength for $\# 5 \mathrm{C}$ Limestone mix. These results indicate that the strengths of specimens with the chemical antistripping additive were lower without than with moisture conditioning. 


\subsection{Analysis for AASHTO T-283 Test Results}

\subsubsection{Analysis for Surface Mixtures}

A statistical analysis was conducted of asphalt mixture tensile strength relative to the effects of wet/dry conditions, anti-stripping treatment, and mixture properties. Test results were analyzed using the Personal Computer (PC) version of the Statistical Analysis System (SAS) software (SAS Institute, Inc. 1991). An analysis of variance (ANOVA) was performed to determine the significance of the effects of certain factors and/or interactions of factors. The class level information is illustrated in Table 4.8. Table 4.9 provides a summary of the General Linear Models (GLM) analysis. Independent variables in the analysis were type of aggregate (AGG), type of treatment (TREAT), moisture condition (MOISTURE), and air void content (AIRVOID). There were 3, 3, and 2 levels, respectively of the independent variables. The dependent variable was indirect tensile strength (STRENG).

The GLM analysis indicated that type of aggregate and treatment both had significant effect on specimen tensile strength. The analysis also showed that moisture conditioning was significant. This means the environmental conditioning procedures in AASHTO T-283 tests reduced the tensile strength of Indiana \#11 surface mixtures.

A Tukey's Studentized Range (HSD) Test was also performed to examine the variability among types of aggregate as well as the effect of treatment on the indirect tensile strength (ITS). Table 4.10 and Table 4.11 show a summary of the statistical 
analysis. It indicates that ITS values for dolomite mixtures are lower than those for limestone and slag mixtures. Also, only hydrated lime significantly increased ITS values for \#11 surface mixtures. A Tukey's Studentized Range (HSD) Test was also performed to examine the variability among the interaction effects on the indirect tensile strength (ITS) and is listed in Table 4.12 and Table 4.13. The effects of interaction are illustrated in Figure 4.10 and Figure 4.11. The effect of aggregate-treatment interaction is significant. Hydrated lime increased the tensile strength of the slag mix. Both hydrated lime and chemical treatment also increased the indirect tensile strength of the \#11 dolomite and limestone mixes. The interaction effect of moisture-treatment is significant. The antistripping agents can have higher ITS value than the control mix after moisture conditioning.

\subsubsection{Analysis for Binder Mixtures}

For \#8 binder mixtures, independent variables in the statistical analysis were type of aggregate (AGG), type of treatment (TREAT), moisture condition (MOISTURE), and air void content (AIRVOID). There were 3, 3, and 2 levels, respectively of the independent variables. An analysis of variance (ANOVA) was performed to determine the significance of the effects of certain factors and/or interactions of factors. The class level information is illustrated in Table 4.14. The dependent variable was indirect tensile strength (STRENG). Table 4.15 presents a summary of the General Linear Models (GLM) analysis. The GLM analysis indicates that type of aggregate had a significant 
effect on the tensile strength of the specimens. The analysis also showed that moisture conditioning was significant in the GLM model. This means the environmental conditioning procedures in AASHTO T-283 test reduced the tensile strength of Indiana \#8 binder mixtures. This is also shown in Figure 4.12.

A Tukey's Studentized Range (HSD) Test was also performed to examine variability among types of aggregate on the indirect tensile strength (ITS). Table 4.16 shows a summary of the analysis. ITS values for slag mixtures are lower than those for limestone and gravel mixtures. A Tukey's Studentized Range (HSD) Test was also performed to examine the variability among the aggregate-moisture interaction effects on the indirect tensile strength (ITS) and is listed in Table 4.17. This means after moisture conditioning, the slag mix has lower ITS than other two types of aggregate. Figure 4.12 also illustrates this result. The statistical analysis is clear about the effect of aggregate type. However, the plotted data does not highlight the effect.

\subsubsection{Analysis for Base Mixtures}

Independent variables in the statistical analysis of the $\# 5 \mathrm{C}$ base mixture were, type of treatment (TREAT), and moisture condition (MOISTURE). There were 3 and 2 levels, respectively of each independent variables. Air void content (AIRVOID) is also one of the independent variables. The class level information is illustrated in Table 4.18. The dependent variable was indirect tensile strength (STRENG). An analysis of variance (ANOVA) was performed to determine the significance of the effects of certain factors 
and/or interactions of factors. Table 4.19 presents a summary of the General Linear Model (GLM) analysis. The GLM analysis indicates that treatment had a significant effect on the tensile strength of the specimen. The analysis also showed that moisture conditioning was significant to the GLM model. The environmental conditioning procedures in AASHTO T-283 tests reduced the tensile strength of \#5C base mixtures.

A Tukey's Studentized Range (HSD) Test was also performed to examine the effect of type of treatment as well as the treatment-moisture interaction on the indirect tensile strength (ITS). These results are shown in Table 4.20 and Table 4.21. The results indicate that ITS values for chemical treated samples are lower than hydrated lime treated and control samples.. The chemical anti-stripping agent reduced the ITS in the dry condition. Figure 4.13 also illustrates this result.

\subsection{Summary}

The AASHTO T-283 test results for the seven mixtures tested indicate that moisture conditioning has a significant effect on the stripping potential of the mixes. This means the environmental conditioning procedures in AASHTO T-283 reduced the tensile strength of the mixtures.

Figure 4.14 shows TSR values for all seven mixtures tested. Clearly, the two antistripping agents increased TSR values except for the \#8 gravel binder mixes. The \#8 gravel mixture used in this study was the only mixture containing $100 \%$ crushed sand. 
The test results based on TSR indicates that a proper portion of crushed sand in the mixture may help to reduce moisture damage and usage of anti-stripping agents.

Comparison of the results for the two antistripping agents based on TSR values indicates that hydrated lime is more effective than the liquid chemical anti-stripping agent. Hydrated lime produces a slightly higher tensile strength for the mixtures before and after moisture conditioning. The liquid chemical anti-stripping agent increased the tensile strength for the mixtures after moisture conditioning. It also can reduce the tensile strength for the mixture before moisture conditioning. 
Table 4.1 AASHTO T-283 Test Results for \#11 Dolomite Mixtures

\begin{tabular}{|c|c|c|c|c|c|c|c|c|}
\hline & \multicolumn{3}{|c|}{ Dry } & \multicolumn{4}{|c|}{ Wet } & \multirow[b]{2}{*}{$\begin{array}{c}\text { TSR, } \\
\%\end{array}$} \\
\hline & $\begin{array}{c}\text { Air Voids, } \\
\%\end{array}$ & $\begin{array}{c}\text { ITS } \\
(\mathrm{kPa})\end{array}$ & $\begin{array}{c}\text { ITS }_{\text {(Average) }} \\
(\mathrm{kPa})\end{array}$ & $\begin{array}{c}\text { Air Voids, } \\
\%\end{array}$ & $\begin{array}{c}\text { Saturation, } \\
\%\end{array}$ & $\begin{array}{l}\text { ITS, } \\
(\mathrm{kPa}) \\
\end{array}$ & $\begin{array}{c}{ }_{1 T S} \text { (Average) } \\
\%\end{array}$ & \\
\hline \multirow{3}{*}{ Control } & 6.49 & 1103 & & 6.59 & 71.1 & 747 & \multirow{3}{*}{738} & \multirow{3}{*}{68} \\
\hline & 6.48 & 1077 & 1089 & 6.74 & 73.3 & 717 & & \\
\hline & 6.80 & 1087 & & 6.44 & 70.2 & 750 & & \\
\hline \multirow{3}{*}{$\begin{array}{l}\text { Pave } \\
\text { Bond }\end{array}$} & 6.87 & 1076 & & 6.76 & 74.5 & 821 & \multirow{3}{*}{842} & \multirow{3}{*}{80} \\
\hline & 6.89 & 1048 & 1053 & 6.84 & 69.1 & 854 & & \\
\hline & 6.73 & 1036 & & 6.91 & 73.7 & 850 & & \\
\hline \multirow{3}{*}{$\begin{array}{l}\text { Hydrated } \\
\text { Lime }\end{array}$} & 6.35 & 1010 & & 6.51 & 65.6 & 856 & \multirow{3}{*}{869} & \multirow{3}{*}{87} \\
\hline & 6.94 & 951 & 1001 & 6.54 & 63.8 & 891 & & \\
\hline & 6.28 & 1041 & & 6.49 & 65.3 & 860 & & \\
\hline
\end{tabular}

Note: ITS: Indirect Tensile Strength

TSR: Tensile Strength Ratio 
Table 4.2 AASHTO T-283 Test Results for \#11 Limestone Mixtures

\begin{tabular}{|c|c|c|c|c|c|c|c|c|}
\hline & \multicolumn{3}{|c|}{ Dry } & \multicolumn{4}{|c|}{ Wet } & \multirow[b]{2}{*}{$\begin{array}{c}\text { TSR, } \\
\%\end{array}$} \\
\hline & $\begin{array}{c}\text { Air Voids, } \\
\%\end{array}$ & $\begin{array}{c}\text { ITS } \\
(\mathrm{kPa})\end{array}$ & $\begin{array}{c}\text { ITS }_{\text {(Averaze) }} \\
(\mathrm{kPa})\end{array}$ & $\begin{array}{c}\text { Air Voids, } \\
\%\end{array}$ & $\begin{array}{c}\text { Saturation, } \\
\%\end{array}$ & $\begin{array}{l}\text { ITS, } \\
(\mathrm{kPa})\end{array}$ & $\begin{array}{c}\operatorname{lTS}_{(\text {Average) }} \\
\%^{-}\end{array}$ & \\
\hline \multirow{3}{*}{ Control } & 7.01 & 1378 & & 7.25 & 71.0 & 896 & \multirow{3}{*}{913} & \multirow{3}{*}{68} \\
\hline & 7.21 & 1349 & 1345 & 7.05 & 70.4 & 885 & & \\
\hline & 6.92 & 1309 & & 6.81 & 71.0 & 958 & & \\
\hline \multirow{3}{*}{$\begin{array}{l}\text { Pave } \\
\text { Bond }\end{array}$} & 6.46 & 1262 & & 6.65 & 71.0 & 985 & \multirow{3}{*}{1022} & \multirow{3}{*}{82} \\
\hline & 6.71 & 1206 & 1254 & 6.70 & 68.1 & 1040 & & \\
\hline & 6.72 & 1295 & & 6.65 & 69.7 & 1043 & & \\
\hline \multirow{3}{*}{$\begin{array}{l}\text { Hydrated } \\
\text { Lime }\end{array}$} & 6.78 & 1320 & & 6.68 & 64.5 & 1032 & \multirow{3}{*}{1081} & \multirow{3}{*}{82} \\
\hline & 6.64 & 1298 & 1320 & 6.82 & 67.1 & 1060 & & \\
\hline & 6.60 & 1341 & & 6.53 & 64.2 & 1150 & & \\
\hline
\end{tabular}

Note: ITS: Indirect Tensile Strength

TSR: Tensile Strength Ratio 
Table 4.3 AASHTO T-283 Test Results for \#11 Slag Mixtures

\begin{tabular}{|c|c|c|c|c|c|c|c|c|}
\hline & \multicolumn{3}{|c|}{ Dry } & \multicolumn{4}{|c|}{ Wet } & \multirow[b]{2}{*}{$\begin{array}{c}\text { TSR, } \\
\%\end{array}$} \\
\hline & $\begin{array}{c}\text { Air Voids, } \\
\%\end{array}$ & $\begin{array}{c}\text { ITS } \\
(\mathrm{kPa})\end{array}$ & $\begin{array}{c}\text { ITS }_{\text {(Average) }} \\
(\mathrm{kPa})\end{array}$ & $\begin{array}{c}\text { Air Voids, } \\
\%\end{array}$ & $\begin{array}{c}\text { Saturation, } \\
\%\end{array}$ & $\begin{array}{l}\text { ITS, } \\
(\mathrm{kPa})\end{array}$ & $\begin{array}{c}\operatorname{ITS}_{\text {(Average) }} \\
\%\end{array}$ & \\
\hline \multirow{3}{*}{ Control } & 6.98 & 1333 & & 7.08 & 71.8 & 853 & \multirow{3}{*}{882} & \multirow{3}{*}{66} \\
\hline & 7.03 & 1331 & 1329 & 6.91 & 70.2 & 877 & & \\
\hline & 7.23 & 1322 & & 7.21 & 73.3 & 915 & & \\
\hline \multirow{3}{*}{$\begin{array}{l}\text { Pave } \\
\text { Bond }\end{array}$} & 6.79 & 1160 & & 6.55 & 69.6 & 973 & \multirow{3}{*}{940} & \multirow{3}{*}{81} \\
\hline & 6.93 & 1176 & 1162 & 6.99 & 65.7 & 914 & & \\
\hline & 6.68 & 1149 & & 6.88 & 68.2 & 933 & & \\
\hline \multirow{3}{*}{$\begin{array}{l}\text { Hydrated } \\
\text { Lime }\end{array}$} & 6.61 & 1357 & & 6.56 & 63.8 & 1171 & \multirow{3}{*}{1109} & \multirow{3}{*}{83} \\
\hline & 6.73 & 1321 & 1334 & 6.74 & 69.1 & 1102 & & \\
\hline & 6.84 & 1323 & & 6.92 & 65.4 & 1055 & & \\
\hline
\end{tabular}

Note: ITS: Indirect Tensile Strength

TSR: Tensile Strength Ratio 
Table 4.4 AASHTO T-283 Test Results for \#8 Gravel Mixtures

\begin{tabular}{|c|c|c|c|c|c|c|c|c|}
\hline & \multicolumn{3}{|c|}{ Dry } & \multicolumn{4}{|c|}{ Wet } & \multirow[b]{2}{*}{$\begin{array}{c}\text { TSR, } \\
\%\end{array}$} \\
\hline & $\begin{array}{c}\text { Air Voids, } \\
\%\end{array}$ & $\begin{array}{c}\text { ITS } \\
(\mathrm{kPa})\end{array}$ & $\begin{array}{l}\text { ITS }_{\text {(Average) }} \\
(\mathrm{kPa})\end{array}$ & $\begin{array}{c}\text { Air Voids, } \\
\%\end{array}$ & $\begin{array}{c}\text { Saturation, } \\
\%\end{array}$ & $\begin{array}{l}\text { ITS, } \\
(\mathrm{kPa})\end{array}$ & $\begin{array}{c}\mathrm{ITS}_{\text {(Average) }} \\
\%\end{array}$ & \\
\hline \multirow{3}{*}{ Control } & 7.16 & 1028 & & 6.49 & 74.4 & 925 & \multirow{3}{*}{890} & \multirow{3}{*}{79} \\
\hline & 6.54 & 1159 & 1133 & 7.07 & 65.8 & 849 & & \\
\hline & 6.72 & 1213 & & 6.89 . & 69.2 & 897 & & \\
\hline \multirow{3}{*}{$\begin{array}{l}\text { Pave } \\
\text { Bond }\end{array}$} & 6.52 & 1045 & & 6.84 & 73.6 & 821 & \multirow{3}{*}{855} & \multirow{3}{*}{74} \\
\hline & 6.53 & 1231 & 1150 & 6.81 & 69.9 & 791 & & \\
\hline & 7.52 & 1175 & & 6.82 & 67.5 & 953 & & \\
\hline \multirow{3}{*}{$\begin{array}{l}\text { Hydrated } \\
\text { Lime }\end{array}$} & 6.76 & 1080 & & 6.27 & 79.4 & 867 & \multirow{3}{*}{859} & \multirow{3}{*}{78} \\
\hline & 6.37 & 1131 & 1097 & 6.48 & 75.1 & 881 & & \\
\hline & 6.26 & 1078 & & 6.51 & 69.4 & 828 & & \\
\hline
\end{tabular}

Note: ITS: Indirect Tensile Strength

TSR: Tensile Strength Ratio 
Table 4.5 AASHTO T-283 Test Results for \#8 Limestone Mixtures

\begin{tabular}{|c|c|c|c|c|c|c|c|c|}
\hline & \multicolumn{3}{|c|}{ Dry } & \multicolumn{4}{|c|}{ Wet } & \multirow[b]{2}{*}{$\begin{array}{c}\text { TSR, } \\
\%\end{array}$} \\
\hline & $\begin{array}{c}\text { Air Voids, } \\
\%\end{array}$ & $\begin{array}{c}\text { ITS } \\
(\mathrm{kPa})\end{array}$ & $\begin{array}{c}\text { ITS }_{\text {(Average) }} \\
(\mathrm{kPa})\end{array}$ & $\begin{array}{c}\text { Air Voids, } \\
\%\end{array}$ & $\begin{array}{c}\text { Saturation, } \\
\%\end{array}$ & $\begin{array}{l}\text { ITS, } \\
(\mathrm{kPa})\end{array}$ & $\begin{array}{c}\text { ITS }_{\text {(Averaze) }} \\
\%\end{array}$ & \\
\hline \multirow{3}{*}{ Control } & 7.39 & 1055 & & 7.72 & 67.9 & 801 & \multirow{3}{*}{839} & \multirow{3}{*}{78} \\
\hline & 7.48 & 1069 & 1082 & 7.74 & 66.4 & 827 & & \\
\hline & 7.76 & 1123 & & 7.35 & 62.3 & 889 & & \\
\hline \multirow{3}{*}{$\begin{array}{l}\text { Pave } \\
\text { Bond }\end{array}$} & 6.70 & 1098 & & 6.50 & 62.5 & 1085 & \multirow{3}{*}{985} & \multirow{3}{*}{85} \\
\hline & 6.90 & 1139 & 1158 & 6.84 & 60.9 & 1055 & & \\
\hline & 6.99 & 1236 & & 7.31 & 65.9 & 815 & & \\
\hline \multirow{3}{*}{$\begin{array}{l}\text { Hydrated } \\
\text { Lime }\end{array}$} & 7.34 & 1077 & & 7.57 & 62.0 & 836 & \multirow{3}{*}{947} & \multirow{3}{*}{84} \\
\hline & 6.75 & 1184 & 1134 & 6.83 & 62.6 & 1018 & & \\
\hline & 7.32 & 1141 & & 6.81 & 59.4 & 987 & & \\
\hline
\end{tabular}

Note: ITS: Indirect Tensile Strength

TSR: Tensile Strength Ratio 
Table 4.6 AASHTO T-283 Test Results for \#8 Slag Mixtures

\begin{tabular}{|c|c|c|c|c|c|c|c|c|}
\hline & \multicolumn{3}{|c|}{ Dry } & \multicolumn{4}{|c|}{ Wet } & \multirow[b]{2}{*}{$\begin{array}{c}\text { TSR, } \\
\%\end{array}$} \\
\hline & $\begin{array}{c}\text { Air Voids, } \\
\%\end{array}$ & $\begin{array}{l}\text { ITS } \\
(\mathrm{kPa})\end{array}$ & $\begin{array}{c}\text { ITS }_{\text {(Average) }} \\
(\mathrm{kPa}) \\
\end{array}$ & $\begin{array}{c}\text { Air Voids, } \\
\%\end{array}$ & $\begin{array}{c}\text { Saturation, } \\
\%\end{array}$ & $\begin{array}{l}\text { ITS, } \\
(\mathrm{kPa}) \\
\end{array}$ & $\begin{array}{c}\text { ITS }_{\text {(Average) }} \\
\%\end{array}$ & \\
\hline \multirow{3}{*}{ Control } & 7.41 & 1293 & & 6.98 & 78.1 & 807 & \multirow{3}{*}{738} & \multirow{3}{*}{60} \\
\hline & 7.06 & 1229 & 1226 & 7.24 & 75.2 & 703 & & \\
\hline & 6.77 & 1156 & & 6.96 & 75.0 & 702 & & \\
\hline \multirow{3}{*}{$\begin{array}{l}\text { Pave } \\
\text { Bond }\end{array}$} & 7.26 & 989 & & 6.80 & 88.2 & 676 & \multirow{3}{*}{696} & \multirow{3}{*}{69} \\
\hline & 6.37 & 1074 & 1010 & 7.12 & 65.4 & 736 & & \\
\hline & 7.37 & 966 & & 7.03 & 74.6 & 676 & & \\
\hline \multirow{3}{*}{$\begin{array}{l}\text { Hydrated } \\
\text { Lime }\end{array}$} & 6.17 & 1105 & & 6.29 & 79.7 & 916 & \multirow{3}{*}{911} & \multirow{3}{*}{89} \\
\hline & 6.40 & 993 & 1027 & 7.05 & 74.6 & 843 & & \\
\hline & 7.49 & 985 & & 6.62 & 77.1 & 974 & & \\
\hline
\end{tabular}

Note: ITS: Indirect Tensile Strength

TSR: Tensile Strength Ratio 
Table 4.7 AASHTO T-283 Test Results for \#5C Limestone Mixtures

\begin{tabular}{|c|c|c|c|c|c|c|c|c|}
\hline & \multicolumn{3}{|c|}{ Dry } & \multicolumn{4}{|c|}{ Wet } & \multirow[b]{2}{*}{$\begin{array}{c}\text { TSR, } \\
\%\end{array}$} \\
\hline & $\begin{array}{c}\text { Air Voids, } \\
\%\end{array}$ & $\begin{array}{c}\text { ITS } \\
(\mathrm{kPa})\end{array}$ & $\begin{array}{c}\text { ITS }_{\text {(Average) }} \\
(\mathrm{kPa})\end{array}$ & $\begin{array}{c}\text { Air Voids, } \\
\%\end{array}$ & $\begin{array}{c}\text { Saturation, } \\
\%\end{array}$ & $\begin{array}{l}\text { ITS, } \\
(\mathrm{kPa})\end{array}$ & $\begin{array}{c}\mathrm{TS}_{\text {(Average) }} \\
\%\end{array}$ & \\
\hline \multirow{3}{*}{ Control } & 7.65 & 1036 & & 7.59 & 58.5 & 693 & \multirow{3}{*}{692} & \multirow{3}{*}{63} \\
\hline & 7.28 & 1059 & 1101 & 7.16 & 58.9 & 713 & & \\
\hline & 7.35 & 1209 & & 7.56 & 58.7 & 671 & & \\
\hline \multirow{3}{*}{$\begin{array}{l}\text { Pave } \\
\text { Bond }\end{array}$} & 7.94 & 905 & & 7.79 & 57.6 & 672 & \multirow{3}{*}{703} & \multirow{3}{*}{76} \\
\hline & 7.88 & 976 & 926 & 8.03 & 56.3 & 701 & & \\
\hline & 7.73 & 897 & & 8.01 & $60 . .5$ & 735 & & \\
\hline \multirow{3}{*}{$\begin{array}{l}\text { Hydrated } \\
\text { Lime }\end{array}$} & 7.63 & 1154 & & 7.69 & 58.8 & 812 & \multirow{3}{*}{804} & \multirow{3}{*}{72} \\
\hline & 7.83 & 1082 & 1116 & 7.65 & 62.9 & 755 & & \\
\hline & 7.88 & 1112 & & 7.92 & 55.1 & 845 & & \\
\hline
\end{tabular}

Note: ITS: Indirect Tensile Strength

TSR: Tensile Strength Ratio 
Table 4.8 Class Level Information-\#11 Surface Mix

\begin{tabular}{|c|c|c|c|c|}
\hline Class & Levels & \multicolumn{3}{|c|}{ Values } \\
\hline AGG & 3 & DOLOMITE & LIMESTONE & SLAG \\
\hline TREAT & 3 & CONTROL & CHEMICAL & LIME \\
\hline MOISTURE & 2 & DRY & WET & \\
\hline \multicolumn{2}{|l}{ Number of observations in data set $=54$}
\end{tabular}

Table 4.9 Summary of Statistical Analysis for \#11 Surface Mixtures

\begin{tabular}{|c|c|c|c|c|c|}
\hline \multicolumn{6}{|c|}{ Dependent Variable: STRENG } \\
\hline Source & $\mathrm{df}$ & $\mathrm{SS}$ & MS & F stat & Prob. $>F$ \\
\hline Model & 35 & 1840832.45 & 52595.21 & 56.43 & 0.0001 \\
\hline Error & 18 & 16777.42 & 932.08 & & \\
\hline Total & 53 & 1857609.87 & & & \\
\hline & & R-Square & Adj. R-Sq. & Root MSE & Mean \\
\hline & & 0.99 & 0.97 & 30.53 & 1071.24 \\
\hline Soumas & $d f$ & Tumg1 CS & $M S$ & $\Gamma-a t$ & $\mathrm{Drrb}>\bar{T}$ \\
\hline $\mathrm{AGG}$ & 2 & 528427.90 & 264213.95 & 283.47 & 0.0001 \\
\hline TREAT & 2 & 49202.43 & 24601.21 & 26.39 & 0.0001 \\
\hline MOISTURE & 1 & 1043850.93 & 1043850.93 & 1119.92 & 0.0001 \\
\hline AIRVOID & 1 & 6047.78 & 6047.78 & 6.49 & 0.0202 \\
\hline AIRVOID*MOISTURE & 1 & 54855.03 & 54855.03 & 58.85 & 0.0001 \\
\hline AIRVOID*AGG & 2 & 3505.56 & 1752.78 & 1.88 & 0.1813 \\
\hline AIRVOID*TREAT & 2 & 4959.32 & 2479.66 & 2.66 & 0.0972 \\
\hline MOISTURE*AGG & 2 & 3286.13 & 1643.06 & 1.76 & 0.1999 \\
\hline MOISTURE*TREAT & 2 & 86743.69 & 43371.84 & 46.53 & 0.0001 \\
\hline AGG*TREAT & 4 & 48020.41 & 12005.10 & 12.88 & 0.0001 \\
\hline $\begin{array}{l}\text { AIRVOID*MOISTURE } \\
\text { *AGG }\end{array}$ & 2 & 207.45 & 103.73 & 0.11 & 0.8953 \\
\hline $\begin{array}{l}\text { AIRVOID*MOISTURE } \\
\text { *TREAT }\end{array}$ & 2 & 609.81 & 304.91 & 0.33 & 0.7252 \\
\hline $\begin{array}{l}\text { AIRVOID*AGG } \\
\text { *TREAT }\end{array}$ & 4 & 2050.34 & 512.58 & 0.55 & 0.7015 \\
\hline $\begin{array}{l}\text { MOISTURE*AGG } \\
\text { *TREAT }\end{array}$ & 4 & 5568.43 & 1392.11 & 1.49 & 0.2458 \\
\hline $\begin{array}{l}\text { AIRVOID*MOISTURE } \\
* \text { AGG }^{*} \text { TREAT }\end{array}$ & 4 & 3497.26 & 874.31 & 0.94 & 644 \\
\hline
\end{tabular}


Table 4.10 Mean Comparison of ITS for Different Types of Aggregate (\#11 Surface)

\begin{tabular}{|l|l|l|l|}
\hline Aggregate & Mean $(\mathrm{kPa})$ & $\mathrm{N}$ & Tukey Grouping \\
\hline Limestone & 1155.94 & 18 & A \\
\hline Slag & 1125.83 & 18 & A \\
\hline Dolomite & 931.94 & 18 & B \\
\hline $\begin{array}{l}\text { Alpha }=0.05, \mathrm{df}=45, \mathrm{MSE}=2396.403 \\
\text { Critical Value of Studentized Range }=3.428 \\
\text { Min. Significant Difference }=39.548\end{array}$ & \\
\hline
\end{tabular}

Table 4.11 Mean Comparison of ITS for Different Treatments (\#11 Surface)

\begin{tabular}{|l|c|c|c|}
\hline \multicolumn{1}{|c|}{ Treatment } & Mean $(\mathrm{kPa})$ & $\mathrm{N}$ & Tukey Grouping \\
\hline Hydrated Lime & 1118.83 & 18 & $\mathrm{~A}$ \\
\hline Control & 1049.28 & 18 & $\mathrm{~B}$ \\
\hline Liquid Additive & 1045.61 & 18 & $\mathrm{~B}$ \\
\hline $\begin{array}{l}\text { Alpha }=0.05, \mathrm{df}=45, \mathrm{MSE}=2396.403 \\
\text { Critical Value of Studentized Range }=3.428 \\
\text { Min. Significant Difference }=39.548\end{array}$ \\
\hline
\end{tabular}


Table 4.12 Mean Comparison of ITS for Aggregate\&Treatment interactions (\#11 Surface)

\begin{tabular}{|l|l|c|c|c|}
\hline \multicolumn{1}{|c|}{ Aggregate } & \multicolumn{1}{|c|}{ Treatment } & Mean $(\mathrm{kPa})$ & $\mathrm{N}$ & Tukey Grouping \\
\hline Slag & Hydrated Lime & 1221.5 & 6 & A \\
\hline Limestone & Hydrated Lime & 1200.2 & 6 & A B \\
\hline Limestone & Liquid Additive & 1138.5 & 6 & B C \\
\hline Limestone & Control & 1129.2 & 6 & C \\
\hline Slag & Control & 1105.2 & 6 & C D \\
\hline Slag & Liquid Additive & 1050.8 & 6 & D \\
\hline Dolomite & Liquid Additive & 947.5 & 6 & E \\
\hline Dolomite & Hydrated Lime & 934.8 & 6 & E \\
\hline Dolomite & Control & 913.5 & 6 & \\
\hline $\begin{array}{l}\text { Alpha }=0.05, \text { df }=18, \text { MSE }=932.08 \\
\text { Critical Value of Studentized Range }=4.96\end{array}$ \\
Min. Significant Difference $=61.76$
\end{tabular}

Table 4.13 Mean Comparison of ITS for Moisture\&Treatment interactions (\#11 Surface)

\begin{tabular}{|l|c|c|c|c|}
\hline \multicolumn{1}{|c|}{ Treatment } & Moisture & Mean $(\mathrm{kPa})$ & N & Tukey Grouping \\
\hline Control & Dry & 1254.3 & 9 & A \\
\hline Hydrated Lime & Dry & 1218.0 & 9 & A \\
\hline Liquid Additive & Dry & 1156.4 & 9 & B \\
\hline Hydrated Lime & Wet & 1019.7 & 9 & C \\
\hline Liquid Additive & Wet & 934.8 & 9 & D \\
\hline Control & Wet & 844.2 & 9 & E \\
\hline $\begin{array}{l}\text { Alpha }=0.05, \text { df }=18, \text { MSE }=932.08 \\
\text { Critical Value of Studentized Range }=4.49 \\
\text { Min. Significant Difference }=45.74\end{array}$ \\
\hline
\end{tabular}


Table 4.14 Class Level Information-\#8 Binder Mix

\begin{tabular}{|l|c|c|c|c|}
\hline \multicolumn{1}{|c|}{ Class } & Levels & \multicolumn{3}{|c|}{ Values } \\
\hline AGG & 3 & GRAVEL & LIMESTONE & SLAG \\
\hline TREAT & 3 & CONTROL & CHEMICAL & LIME \\
\hline MOISTURE & 2 & DRY & WET & \\
\hline \multicolumn{4}{|l}{ Number of observations in data set $=54$} \\
\hline
\end{tabular}

Table 4.15 Summary of Statistical Analysis for \#8 Binder Mixtures

\begin{tabular}{|c|c|c|c|c|c|}
\hline \multicolumn{6}{|c|}{ Dependent Variable: STRENG } \\
\hline Source & $\mathrm{df}$ & SS & $\mathrm{MS}$ & F stat & Prob. $>\mathrm{F}$ \\
\hline Model & 35 & 1310495.31 & 37442.72 & 9.52 & 0.0001 \\
\hline Error & 18 & 70825.53 & 3934.75 & & \\
\hline Total & 53 & 1381320.83 & & & \\
\hline & & R-Square & Adj. R-Sq. & Root MSE & Mean \\
\hline & & 0.95 & 0.85 & 62.73 & 985.39 \\
\hline Sourmo & $d f$ & T-m 18 & $M S$ & $\Gamma$ & $D_{r}+r$ \\
\hline \begin{tabular}{|l} 
Source \\
$A G G$
\end{tabular} & $\frac{d t}{n}$ & 1ype 1 SS & $\frac{\mathrm{MS}}{5080120}$ & F stat & $\frac{\text { Prob. }>\mathrm{F}}{00003}$ \\
\hline TREAT & $\frac{2}{2}$ & $\frac{101 / 02.40}{9572.05}$ & $\frac{50881.20}{4786.03}$ & $\frac{12.95}{1.22}$ & $\begin{array}{l}0.0003 \\
0.3159\end{array}$ \\
\hline MOISTURE & 1 & 871575.03 & 871575.03 & 221.51 & 0.0001 \\
\hline AIRVOID & 1 & 27886.35 & 27886.35 & 7.09 & 0.0159 \\
\hline AIRVOID*MOISTURE & 1 & 23885.43 & 23885.43 & 6.07 & 0.0240 \\
\hline AIRVOID*AGG & 2 & 26889.26 & 13444.63 & 3.42 & 0.0552 \\
\hline AIRVOID*TREAT & 2 & 3619.08 & 1809.54 & 0.46 & 0.6386 \\
\hline MOISTURE*AGG & 2 & 68268.33 & 34134.17 & 8.68 & 0.0023 \\
\hline MOISTURE*TREAT & 2 & 25276.58 & 12638.29 & 3.21 & 0.0641 \\
\hline AGG*TREAT & 4 & 38325.16 & 9581.29 & 2.44 & 0.0848 \\
\hline $\begin{array}{l}\text { AIRVOID*MOISTURE* } \\
\text { AGG }\end{array}$ & 2 & 8565.54 & 4282.77 & 1.09 & 0.3579 \\
\hline $\begin{array}{l}\text { AIRVOID*MOISTURE* } \\
\text { TREAT }\end{array}$ & 2 & 2058.60 & 1029.30 & 0.26 & 0.7727 \\
\hline $\begin{array}{l}\text { AIRVOID*AGG } \\
\text { *TREAT }\end{array}$ & 4 & 34633.56 & 8658.39 & 2.20 & 0.1099 \\
\hline $\begin{array}{l}\text { MOISTURE*AGG } \\
\text { *TREAT }\end{array}$ & 4 & 46108.08 & 11527.02 & 2.93 & 0.0499 \\
\hline $\begin{array}{l}\text { AIRVOID*MOISTURE } \\
\text { *AGG*TREAT }\end{array}$ & 4 & 22069.85 & 5517.46 & 1.40 & 0.2732 \\
\hline
\end{tabular}


Table 4.16 Mean Comparison of ITS for Different Types of Aggregate (\#8 Binder)

\begin{tabular}{|l|c|c|c|}
\hline \multicolumn{1}{|c|}{ Aggregate } & Mean $(\mathrm{kPa})$ & $\mathrm{N}$ & Tukey Grouping \\
\hline Limestone & 1024.17 & 18 & $\mathrm{~A}$ \\
\hline Gravel & 997.33 & 18 & $\mathrm{~A}$ \\
\hline Slag & 934.67 & 18 & $\mathrm{~B}$ \\
\hline $\begin{array}{l}\text { Alpha }=0.05, \mathrm{df}=35, \mathrm{MSE}=4467.584 \\
\text { Critical Value of Studentized Range }=3.461 \\
\text { Min. Significant Difference }=54.525\end{array}$ \\
\hline
\end{tabular}

Table 4.17 Mean Comparison of ITS for Aggregate \& Moisture interactions (\#8 Binder)

\begin{tabular}{|l|c|c|c|c|}
\hline \multicolumn{1}{|c|}{ Aggregate } & Moisture & Mean $(\mathrm{kPa})$ & $\mathrm{N}$ & Tukey Grouping \\
\hline Gravel & Dry & 1126.7 & 9 & $\mathrm{~A}$ \\
\hline Limestone & Dry & 1124.7 & 9 & $\mathrm{~A}$ \\
\hline Slag & Dry & 1087.8 & 9 & A \\
\hline Limestone & Wet & 923.7 & 9 & B \\
\hline Gravel & Wet & 868.0 & 9 & B C \\
\hline Slag & Wet & 781.6 & 9 & C \\
\hline $\begin{array}{l}\text { Alpha }=0.05, \text { df }=18, \text { MSE }=3934.75 \\
\text { Critical Value of Studentized Range }=4.49 \\
\text { Min. Significant Difference }=93.98\end{array}$ \\
\hline
\end{tabular}


Table 4.18 Class Level Information-\#5C Base Mix

\begin{tabular}{|l|c|c|c|c|}
\hline \multicolumn{1}{|c|}{ Class } & Levels & \multicolumn{3}{|c|}{ Values } \\
\hline TREAT & 3 & CONTROL & CHEMICAL & LIME \\
\hline MOISTURE & 2 & DRY & WET & \\
\hline
\end{tabular}

Table 4.19 Summary of Statistical Analysis for \#5C Base Mixtures

\begin{tabular}{|l|c|c|c|c|c|}
\hline \multicolumn{5}{|c|}{ Dependent Variable: STRENG } \\
\hline Source & df & SS & MS & F stat & Prob. $>$ F \\
\hline Model & 9 & 544703.75 & 60522.64 & 21.86 & 0.0001 \\
\hline Error & 8 & 22148.53 & 2768.57 & & \\
\hline Total & 17 & 566852.28 & & & \\
\hline & & R-Square & Adj. R-Sq. & Root MSE & Mean \\
\cline { 3 - 7 } & & 0.96 & 0.92 & 52.62 & 890.39 \\
\hline & df & Type 1 SS & MS & F stat & Prob. > F \\
\hline Source & 2 & 64030.11 & 32015.06 & 11.56 & 0.0044 \\
\hline TREAT & 1 & 445882.72 & 445882.72 & 161.05 & 0.0001 \\
\hline MOISTURE & 2 & 5.11 & 5.11 & 0.00 & 0.9668 \\
\hline AIRVOID & 2 & 26218.38 & 13109.19 & 4.74 & 0.0440 \\
\hline TREAT*MOISTURE & 2 & 4803.46 & 2401.73 & 0.87 & 0.4561 \\
\hline AIRVOID*TREAT & 2 & 3763.97 & 3763.97 & 1.36 & 0.2772 \\
\hline AIRVOID*MOISTURE & 1 & 376 & & \\
\hline
\end{tabular}


Table 4.20 Mean Comparison of ITS for Different Treatments (\#5C Base)

\begin{tabular}{|l|c|c|c|}
\hline \multicolumn{1}{|c|}{ Treatment } & Mean $(\mathrm{kPa})$ & $\mathrm{N}$ & Tukey Grouping \\
\hline Hydrated Lime & 960.00 & 6 & $\mathrm{~A}$ \\
\hline Control & 896.83 & 6 & $\mathrm{~A}$ \\
\hline Liquid Additive & 814.33 & 6 & $\mathrm{~B}$ \\
\hline $\begin{array}{l}\text { Alpha }=0.05, \mathrm{df}=12, \mathrm{MSE}=2589 \\
\text { Critical Value of Studentized Range }=3.773 \\
\text { Min. Significant Difference }=78.37\end{array}$ \\
\hline
\end{tabular}

Table 4.21 Mean Comparison of ITS for Moisture\&Treatment interactions (\#5C Base)

\begin{tabular}{|l|c|c|c|c|}
\hline \multicolumn{1}{|c|}{ Treatment } & Moisture & Mean $(\mathrm{kPa})$ & N & Tukey Grouping \\
\hline Hydrated Lime & Dry & 1116.0 & 3 & A \\
\hline Control & Dry & 1101.3 & 3 & A \\
\hline Liquid Additive & Dry & 926.0 & 3 & B \\
\hline Hydrated Lime & Wet & 804.0 & 3 & B C \\
\hline Liquid Additive & Wet & 702.7 & 3 & C \\
\hline Control & Wet & 692.3 & 3 & C \\
\hline $\begin{array}{l}\text { Alpha }=0.05, \text { df }=8, \text { MSE }=2768.57 \\
\text { Critical Value of Studentized Range }=5.17 \\
\text { Min. Significant Difference }=156.97\end{array}$ \\
\hline
\end{tabular}




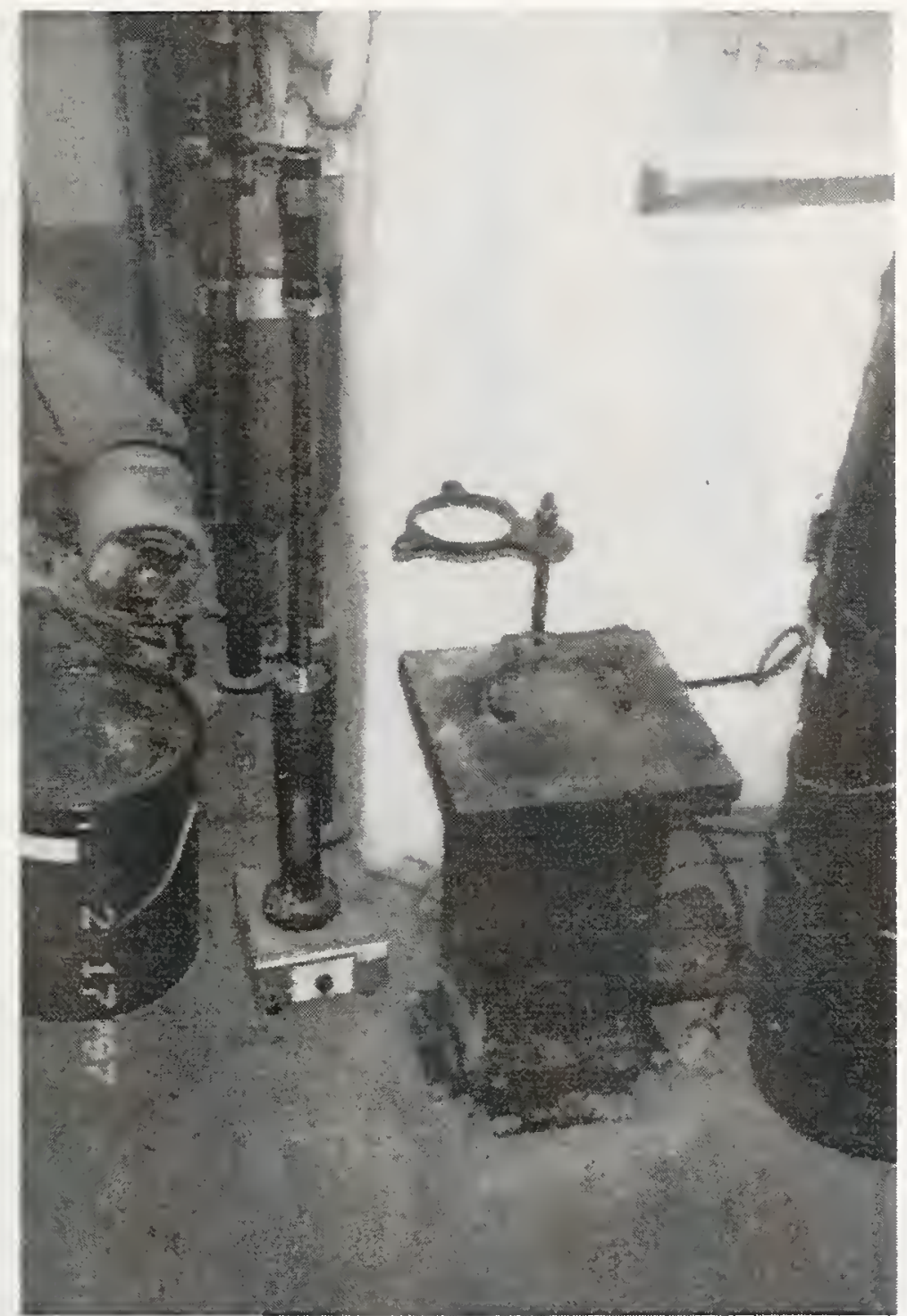

Figure 4.1 Manual Marshall Hand Hammer 


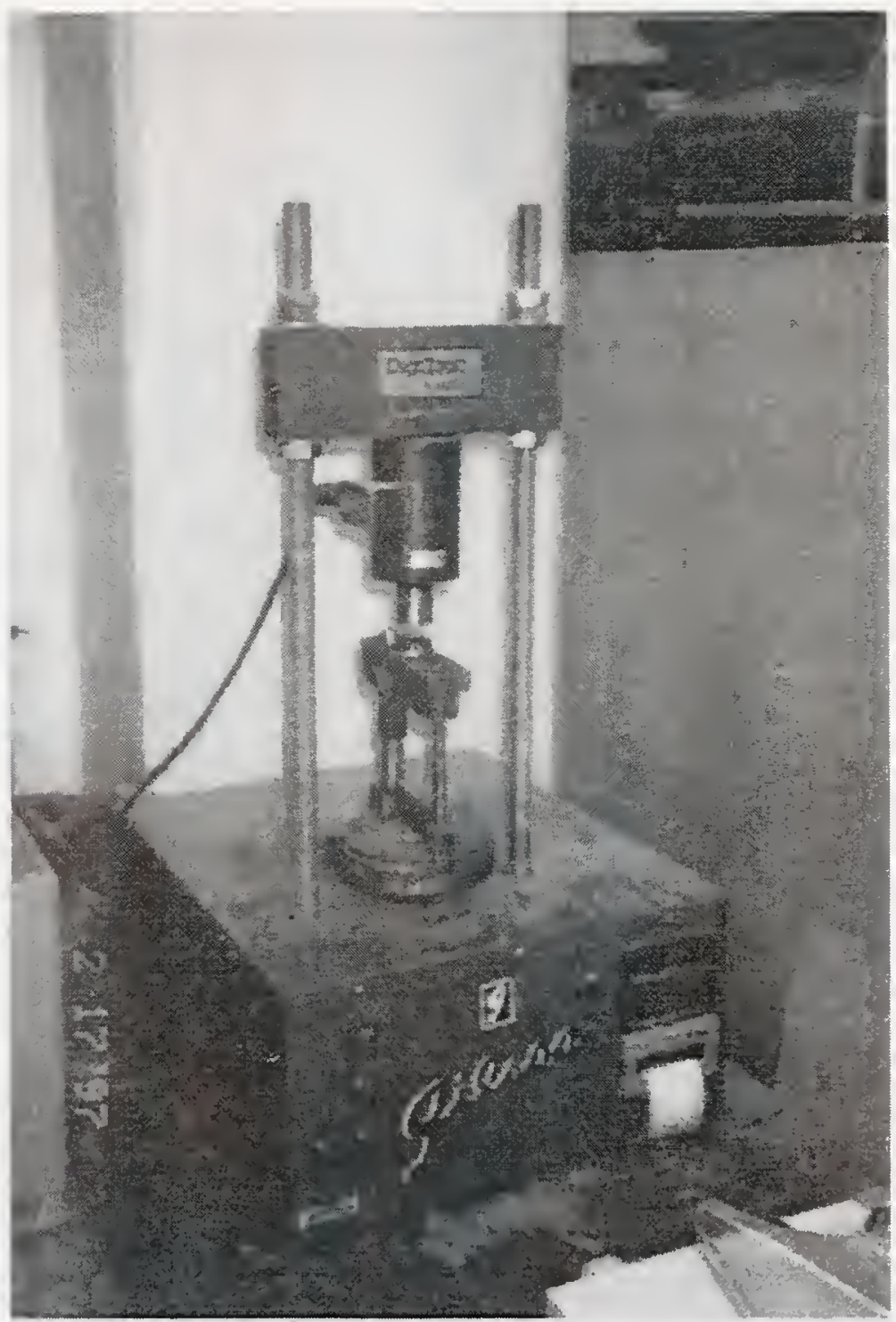

Figure 4.2 Indirect Tensile Test Apparatus 
\#11 Dolomite

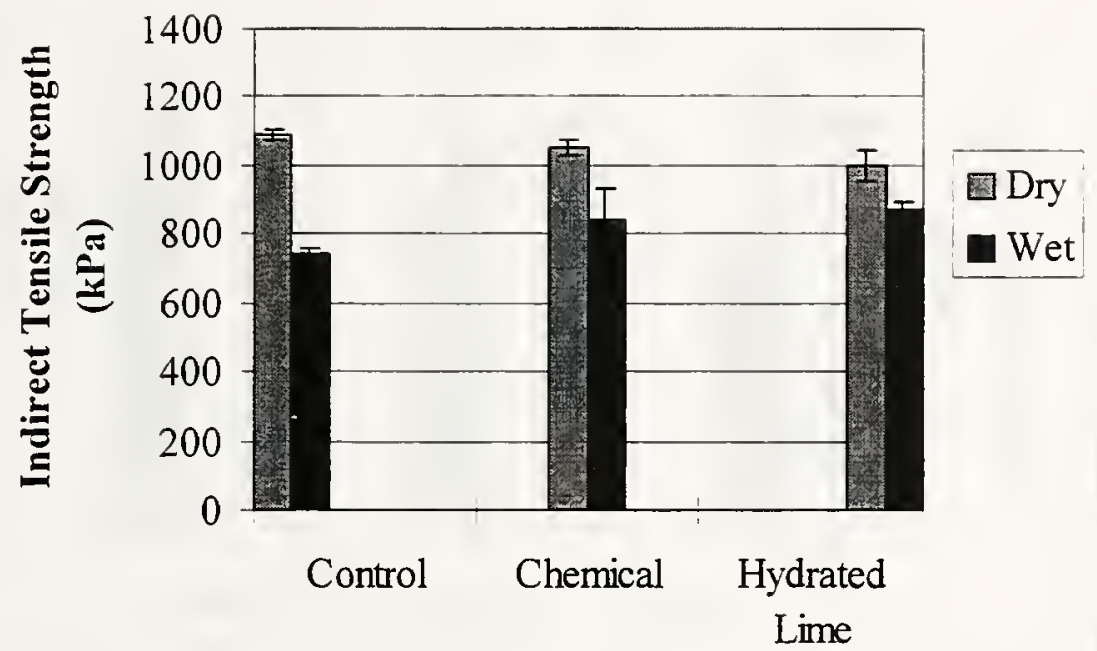

* Each bar represents the average value of 3 samples

Figure 4.3 Indirect Tensile Strength for \#11 Dolomite Mix

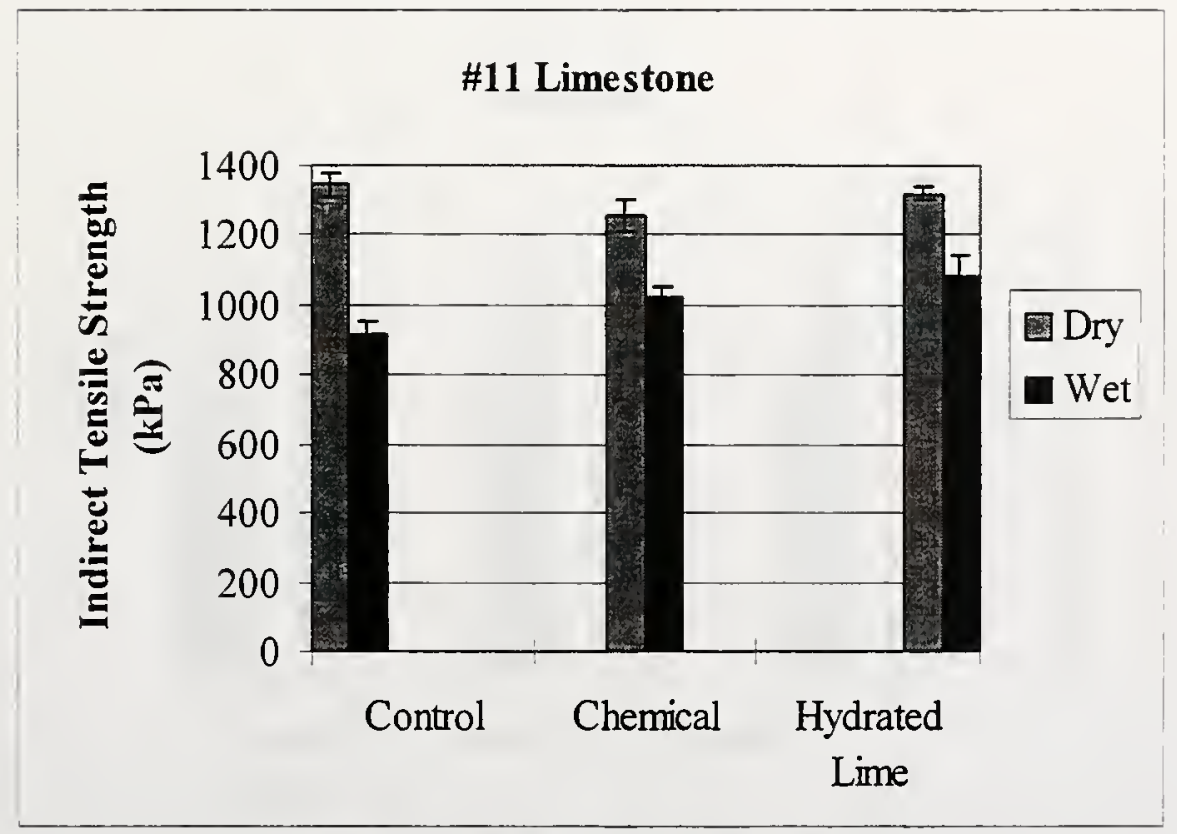

* Each bar represents the average value of 3 samples

Figure 4.4 Indirect Tensile Strength for \#11 Limestone Mix 


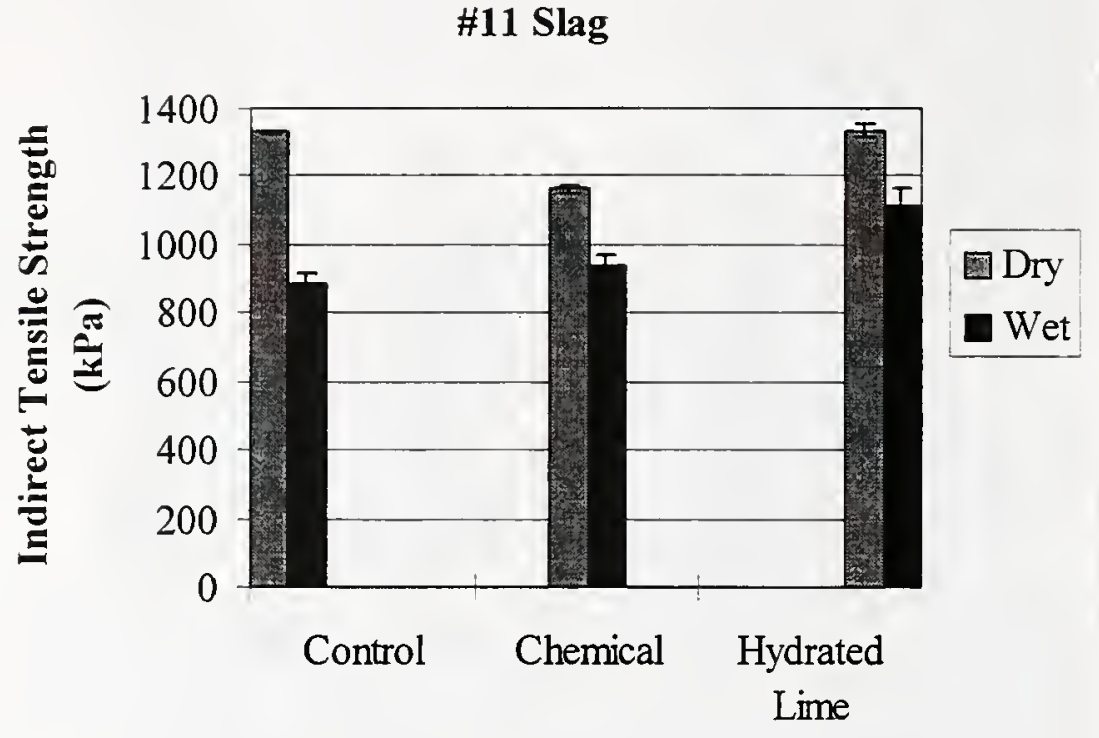

* Each bar represents the average value of 3 samples

Figure 4.5 Indirect Tensile Strength for \#11 Slag Mix

\#8 Gravel

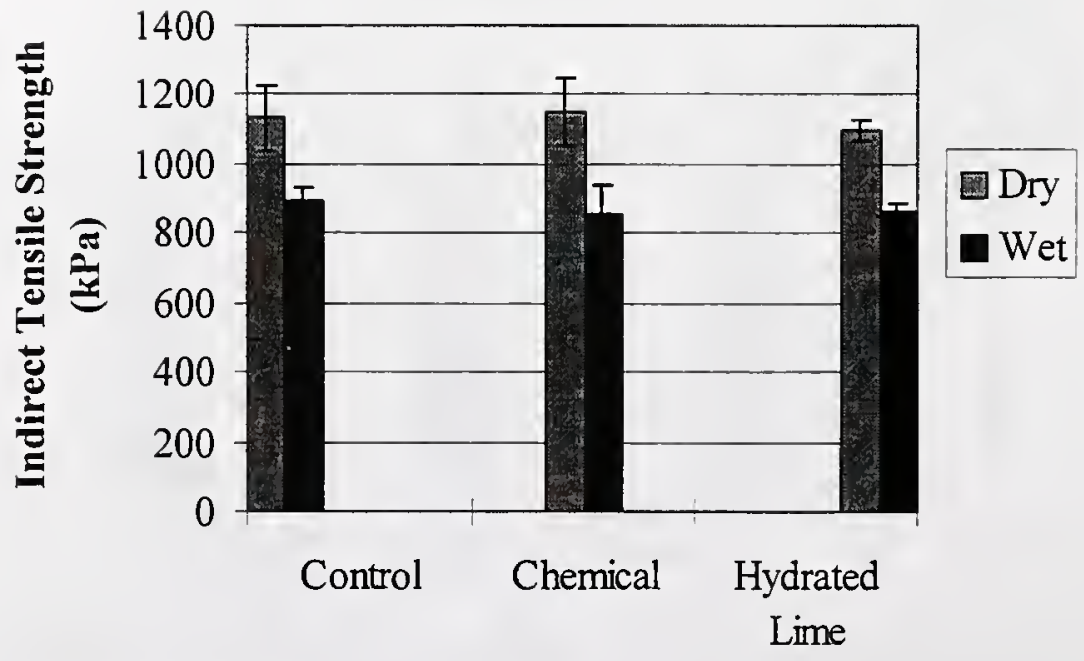

* Each bar represents the average value of 3 samples

Figure 4.6 Indirect Tensile Strength for \#8 Gravel Mix 
\#8 Limestone

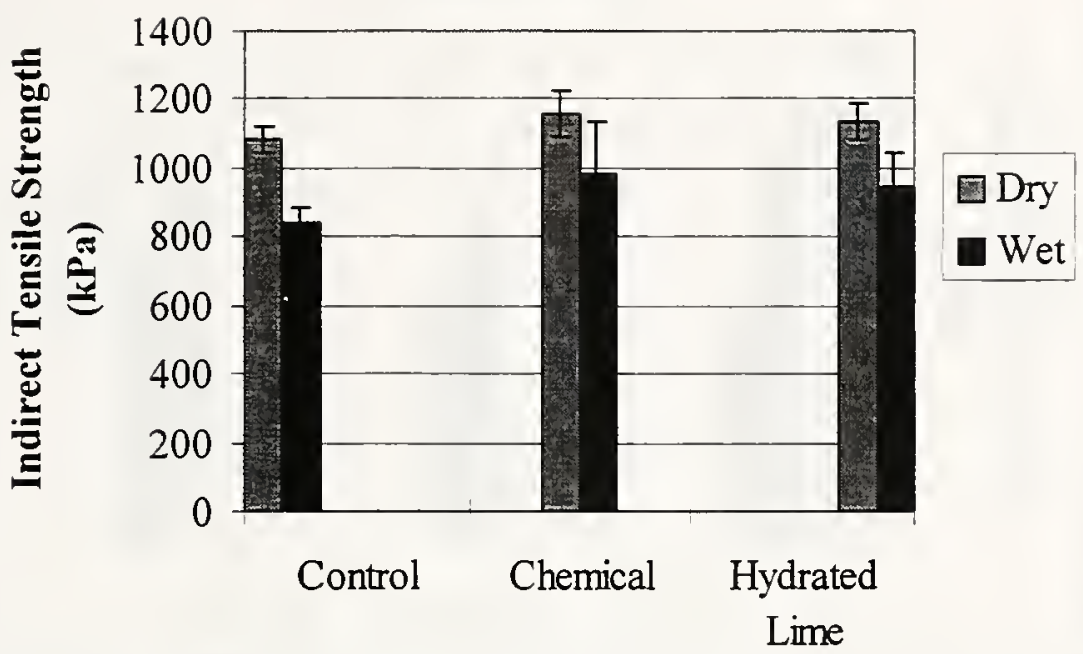

* Each bar represents the average value of 3 samples

Figure 4.7 Indirect Tensile Strength for \#8 Limestone Mix

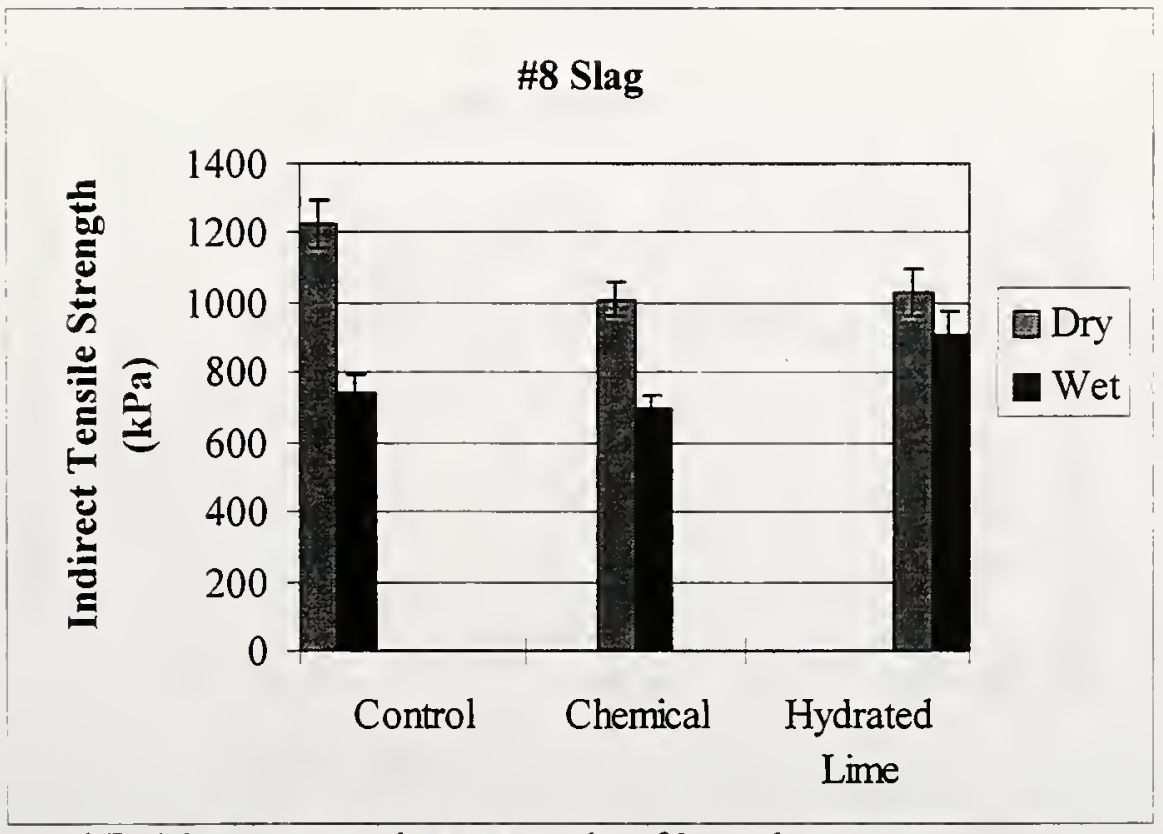

* Each bar represents the average value of 3 samples

Figure 4.8 Indirect Tensile Strength for \#8 Slag Mix 
\#5C Limes tone

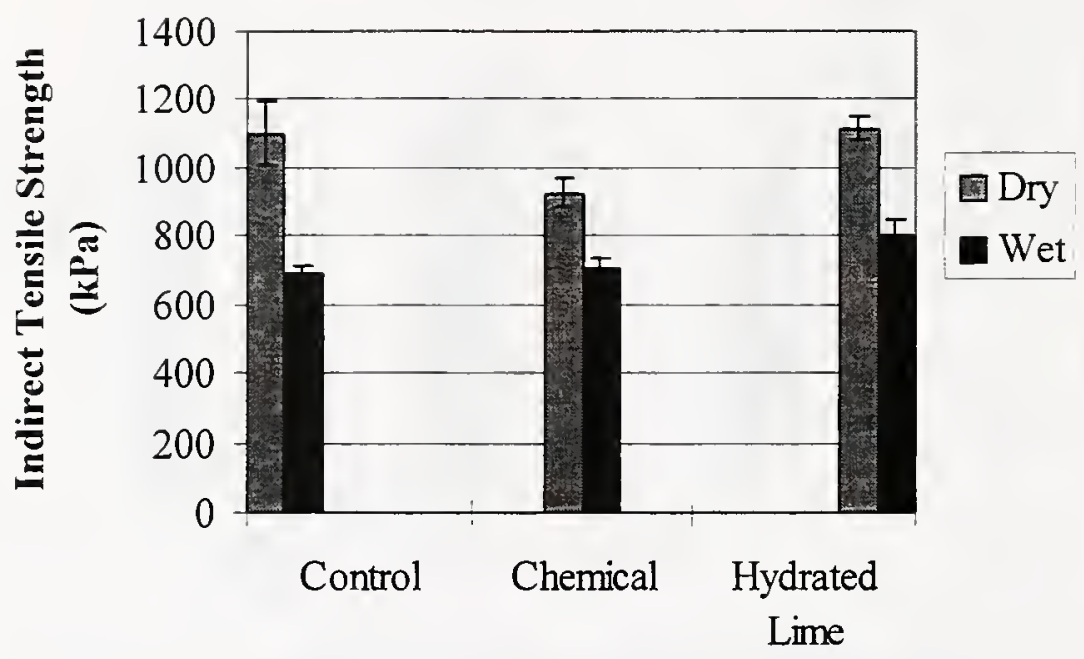

* Each bar represents the average value of 3 samples

Figure 4.9 Indirect Tensile Strength for \#5C Limestone Mix

\#11 Surface Mix

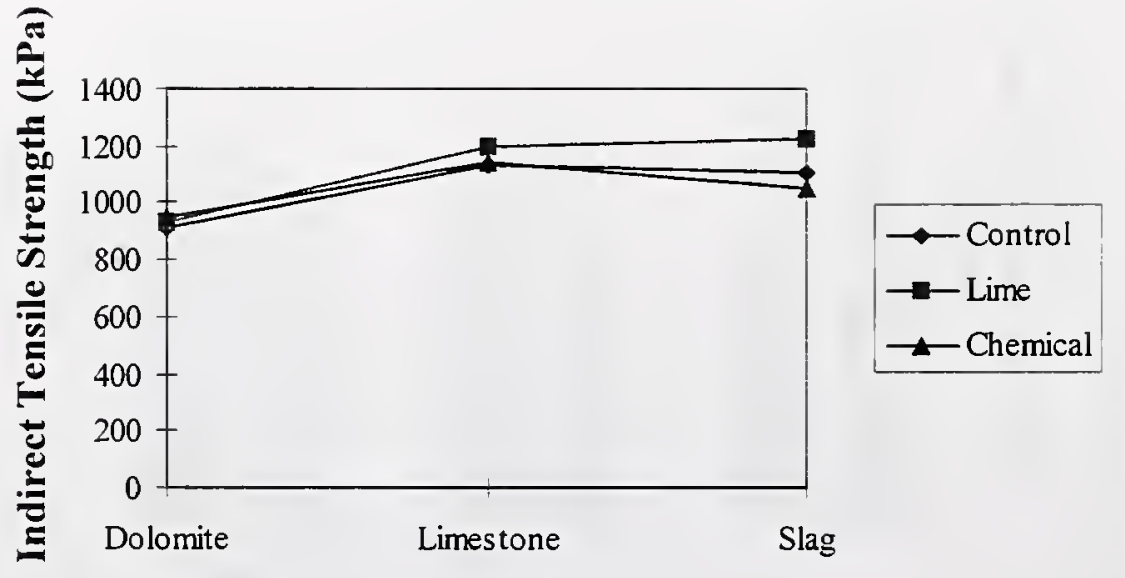

Figure 4.10 Plot of Mean Indirect Tensile Strength by Aggregate and Treatment (\#11 Surface Mix) 


\section{\#11 Surface Mix}

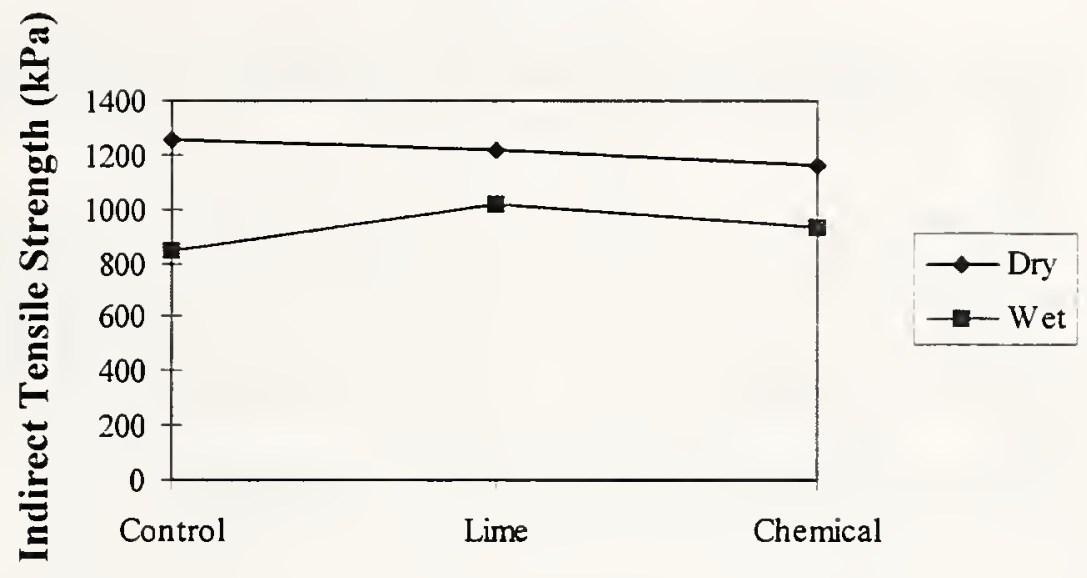

Figure 4.11 Plot of Mean Indirect Tensile Strength by Moisture and Treatment (\#11 Surface Mix)

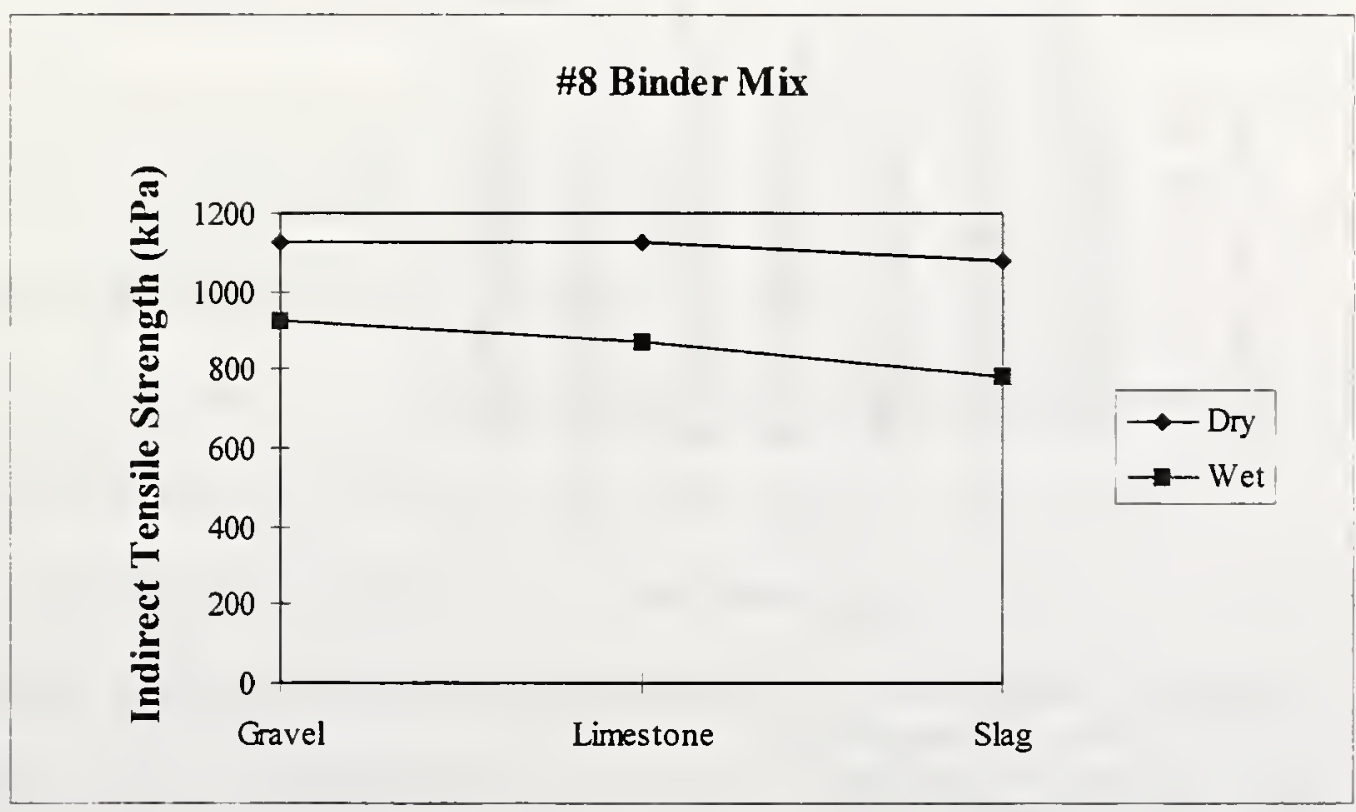

Figure 4.12 Plot of Mean Indirect Tensile Strength by Aggregate and Moisture (\#8 Binder Mix) 
\#5C Base Mix

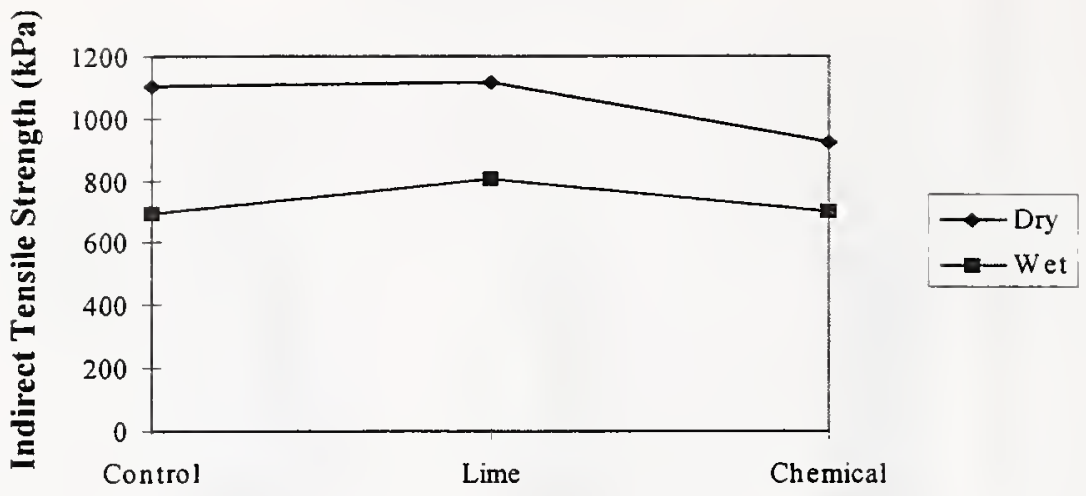

Figure 4.13 Plot of Mean Indirect Tensile Strength by Moisture and Treatment (\#5C Base Mix)

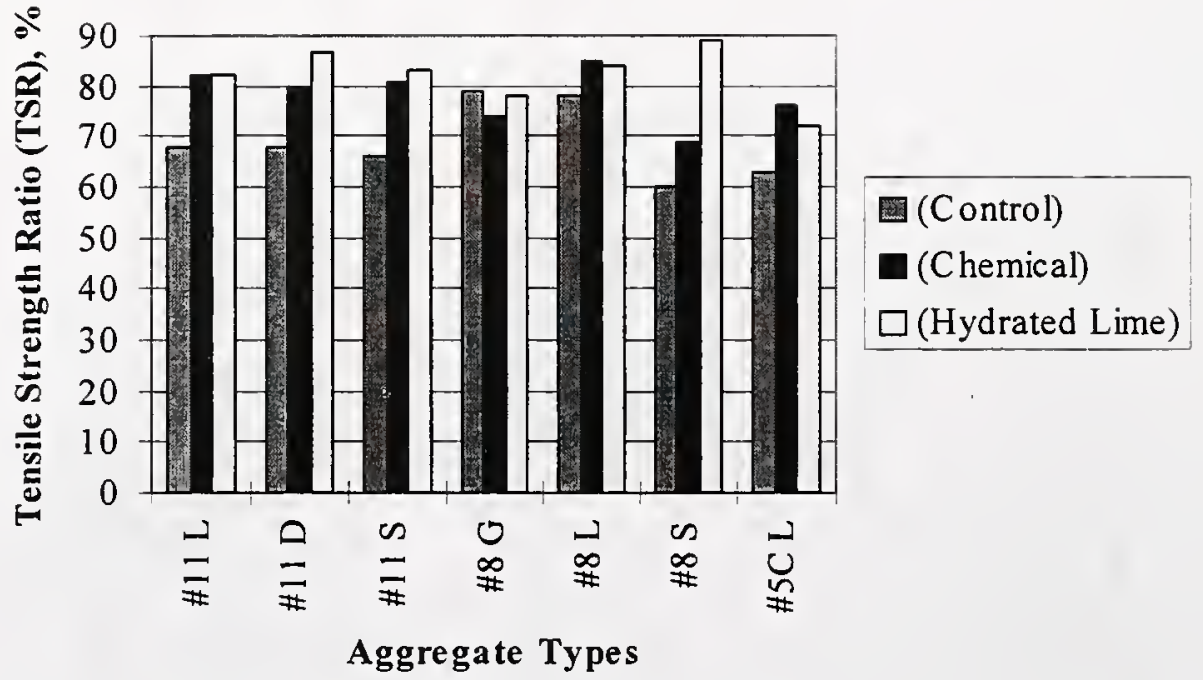

\#11L: :\#11 dolomite surface mixture

\#11D: :\#11 limestone surface mixture

\#11S: :\#11 slag surface mixture

\#8G: \#8 gravel binder mixture

\#8L: :\#8 limestone binder mixture

\#8S: $: \# 8$ slag binder mixture

\#5CL: :\#5C limestone base mixture

Figure 4.14 TSR Results for AASHTO T-283 Tests 


\section{CHAPTER 5 LABORATORY WHEEL TRACKING TESTING}

This chapter describes and presents results of laboratory work conducted using the Purdue wheel (PURWheel) testing device. Tests were conducted on mixtures described in Chapter Three. Development of the testing equipment and techniques are also discussed.

\subsection{Introductions}

The Purdue wheel testing Device (PURWheel), a laboratory wheel tracking device, was developed specifically for this study. Design of the PURWheel was predicated on creating conditions associated with both rutting and stripping. These conditions include high moisture, high temperature and moving wheel load. Tests can be conducted on laboratory compacted specimens as well as specimens taken from in-service pavements. A recent proposal was made to package the unit for testing field test sections.

The PURWheel laboratory wheel test device (shown in Figure 5.1) was designed and fabricated to evaluate the stripping/rutting performance of bituminous mixtures. Two specimens can be tested simultaneously. The test environment can be either hot/wet or hot/dry. Typical test temperature ranges from $55^{\circ} \mathrm{C}$ to $60^{\circ} \mathrm{C}$, although the test 
temperature can vary from room temperature to $65^{\circ} \mathrm{C}$. In application specimens are compacted to $6 \sim 8 \%$ air voids with the Purdue linear compactor (see Figure 5.2). Specimen dimensions are typically $29.0 \mathrm{~cm}$ wide and $31.0 \mathrm{~cm}$ long. Specimen depth varies depending on the type of mixture being tested. For example, surface, binder and base mixtures are $3.8 \mathrm{~cm}, 5.1 \mathrm{~cm}, 7.6 \mathrm{~cm}$, respectively. A pneumatic tire is loaded to achieve a gross contact pressure of about $620 \mathrm{kPa}$ with a $793 \mathrm{kPa}$ tire pressure. The wheel velocity selected for these tests was $33 \pm 2 \mathrm{~cm} / \mathrm{sec}(1.1 \mathrm{ft} / \mathrm{sec}$ or $1 \mathrm{mph})$. In this study, each specimen was subjected to 20,000 wheel passes or until $20.0 \mathrm{~mm}$ of deformation developed. Figure 5.3 illustrates a typical PURWheel test result. The test data includes creep slope, number of wheel passes and rut depth for the stripping inflection point, and stripping slope (if available). Design characteristics of the test apparatus, sample preparation, test results and analysis are included in subsequent sections.

\subsection{Laboratory Wheel Test Apparatus Development}

Two major pieces of equipment for the laboratory wheel track testing were developed in this study. They are: (1) Laboratory linear compactor, and (2) Purdue wheel testing device (PURWheel). The linear compactor was designed and fabricated to produce samples for PURWheel testing, bending fatigue tests and Nuclear density and moisture (asphalt) content testing. Both devices are described in the following sections. 


\subsubsection{Laboratory Linear Compactor}

The linear laboratory compactor was designed and fabricated as a multi-purpose compactor. Its design concept is based on a similar device developed for Koch asphalt in preparing samples for the Hamburg Steel Wheel Tester (HSWT) (Habermann, 1994). The modifications included facility for compacting larger slabs. Maximum length and width of slabs that can be prepared are $62.2 \mathrm{~cm}$ by $30.5 \mathrm{~cm}$. These dimension were selected as part of the design parameters for the PURWheel Testing device to minimize end and side boundary effects. Maximum slab thickness that can be prepared is $10.2 \mathrm{~cm}$. This thickness was selected to minimize bottom boundary effects in nuclear density and moisture (asphalt) content measurements. A $10.2 \mathrm{~cm}$ thickness also allows $7.6 \mathrm{~cm}$ by $38.1 \mathrm{~cm}$ beams for bending fatigue tests to be sawn. The Purdue linear compactor is shown in Figure 5.4. Essential features of the linear compactor include a $304.8 \mathrm{~mm}$ (12 in.) X $622.3 \mathrm{~mm}$ (24.5 in.) rectangular steel mold attached to an air cylinder, a set of steel plates, a loading frame with a steel roller, and a hydraulic ram to apply a compaction force. The Koch linear compactor and the initial Purdue design had a threaded, vertical steel rod (Figure 5.5) to apply the compaction force. Compactive load was applied to the loading frame through the attached roller to the steel plates by turning the rod. In operation the rod is turned, applying load on the plates until the sample in the steel mold is at the desired thickness. The threaded rod failed a number of times and contributed to sample density variations because load varied as the sample compacted. A modification involved replacing the threaded rod with a hydraulic ram (Figure 5.6). Hydraulic pressure is supplied by an electric powered hydraulic pump. With the hydraulic loading the force 
is constant. The result was that compaction for most mixtures was reduced from thirty to five minutes. Target density can be achieve by compacting the material into a certain volume. A slab sample can also be used for other tests as noted above. In addition, cored sample can obtain for indirect tensile as well as creep tests. The linear compactor has proven to be an effective, flexible laboratory compaction device.

\subsubsection{Development of The Wheel Track Testing Device}

There are several laboratory wheel testing devices being utilized in the U.S. The devices include Laboratoire Central des Ponts et Chaussees (LCPC) French Rutting Tester, Georgia Loaded Wheel Tester (GLWT), and Hamburg Steel Wheel Tracking (HSWT) Device. A survey is currently being conducted by an American Society for Testing Materials Subcommittee on features of such devices. The purpose of the survey is to evaluate the need for a standard. There is increasing interest in the potential of predicting stripping/rutting performance of asphalt mixtures. Conceptionally, wheel tracking tests simulates the effect of moving wheel loads. After reviewing the features of available wheel testing devices, the Hamburg Wheel Tracking Device which tests compacted slabs immersed in hot water was considered a more effective device. This was based on the history of its application and the goal of the current study.

Since a new device was to be fabricated, a number of features were added to the basic Hamburg Steel Wheel Testing concept. The added features included: 
1. Use of two air cylinders to drive the wheels independently as well as achieve a constant speed throughout the stroke,

2. A wheel mounting assembly for different types of wheels (steel, rubber coated, or pneumatic),

3. A transverse mechanism to incorporate wheel wander (Figure 5.7).

4. A larger sample box to minimize boundary effects (Figure 5.8).

5. Ability to measure rut depth for entire length of specimen using movable transducers (Figure 5.9).

Additionally, the testing chamber was modified so that tests can be conducted in hot/dry as well as in hot/wet conditions. The heating system for the hot/dry condition included circulating hot water through conduits in plate under the specimen. Figure 5.10 shows features of the heating system. An additional air heating device was added to minimize sample/air temperature differential and ensure uniform temperature through the specimen. The air heating system uses electric resistance heating elements and a blower as shown in Figure 5.11. Thermocouples embedded in dummy samples were used to determine time of heating.

Initial tests were conducted with samples $304.8 \mathrm{~mm}$ (12 in.) wide by $622.3 \mathrm{~mm}$ (24.5 in.) long. In these tests the rutting appeared to be uniform. As a result, a decision was made to reduce the length of the sample to one-half of its original length. Concrete blocks with the same thickness of the sample were used to fill in on both ends. Figure 5.12 illustrates rutting. 


\subsection{Test Parameters}

The PURWheel design proved to be flexible, allowing numerous test configurations. However, the intent of this study was to evaluate the performance of the asphalt mixtures under simulated service conditions. Simulation involved matching actual ambient factors, such as load, geometry, and temperature. In service pavement thickness varies depending on type of mixture. Target test slab thickness were selected based on the usual thickness for the various mixtures, i.e. surface, binder and base. They are 1.5 in. $(38 \mathrm{~mm}), 2$ in. $(51 \mathrm{~mm})$, and 3 in. $(76 \mathrm{~mm})$ for the surface, binder, and base mixtures respectively.

\subsubsection{Tire Contact Pressure}

The majority of tests conducted with the APT were with a tire pressure of $620 \mathrm{kPa}$ (90 psi). Gross tire contact pressure of the APT tire based on applied load and tire print area was also $620 \mathrm{kpa}(90 \mathrm{psi})$. In order to achieve this level of contact pressure, a $175 \mathrm{~kg}$ load was applied to each wheel at a tire inflation pressure was $793 \mathrm{kpa}(115 \mathrm{psi})$. The contact pressure is equal to the following:

$$
\sigma=\frac{P}{A}
$$

where: 
$\sigma=$ Gross wheel contact pressure,

$\mathrm{P}=$ Wheel load, and

$A=$ Gross contact area between tire and sample surface.

Typical thicknesses for surface and binder layers in Indiana are $38.1 \mathrm{~mm}$ and 50.8 $\mathrm{mm}$, respectively. In order to estimate the stress at the top of the binder and base layers, an analysis was made using Bitumen Structures Analysis in Roads (BISAR) software which was developed by Shell (De Jong, et al., 1973). It is a linear-elastic, multilayered system program for computing stresses, strains and deflections resulting from one or more uniform circular loads at a surface. Figure 5.13 shows the stress distribution using BISAR. These results are for $620 \mathrm{kPa}$ surface loading. Since the reduction in stress for the $38.1 \mathrm{~mm}$ surface layer is minimal and traffic is allowed on binder surfaces, the same stress was assumed for both the surface and the binder mixtures. The BISAR results also indicates a stress of $517 \mathrm{kPa}$ at a depth of $89 \mathrm{~mm}(3.5 \mathrm{in}$.) which is typically the top of the base mixture.

\subsubsection{Test Temperature}

Performance of asphalt mixture is influenced significantly by temperature. The elastic modulus decreases with increasing temperature and as a result stresses on underlying materials will increase as a result of the larger stresses, the asphalt mixture will deform viscously resulting in permanent deformation. 
To estimate pavement temperature profiles in Indiana, a finite difference heat transfer model developed by Gupta (1987) was utilized. The model input includes ambient air temperature and solar radiations. Figure 5.15 illustrates the highest hourly pavement surface temperatures in Indiana which is from the heat transfer model output results. As a worst case condition, a temperature of $60^{\circ} \mathrm{C}\left(140^{\circ} \mathrm{F}\right)$ was assumed for surface mixture tests. As noted above surface mixtures in Indiana average $38.1 \mathrm{~mm}(1.5$ inches) thick. The finite difference analysis predicted a temperature gradient of $2.5^{\circ} \mathrm{C}$ $\left(4.5^{0} \mathrm{~F}\right)$ for the $38.1 \mathrm{~mm}$ surface course thickness. As a result, a test temperature of $57.5^{\circ}$ $\mathrm{C}\left(135^{0} \mathrm{~F}\right)$ was adapted for binder mixtures. Binder thickness average $50.8 \mathrm{~mm}(2 \mathrm{in}$.). A temperature gradient of $6.0^{\circ} \mathrm{C}$ would be expected for the pavement at $89 \mathrm{~mm}$ in depth. Consequently, a test temperature of $54.0^{\circ} \mathrm{C}$ was adopted for base mixtures.

\subsection{Sample Preparation and Test Procedures}

Plan dimensions of slabs prepared for this study averaged $304.8 \mathrm{~mm}$ wide and $622.3 \mathrm{~mm}$ long. Surface and binder course slab thickness were $38 \mathrm{~mm}$ and $76 \mathrm{~mm}$ respectively. The aggregate was batched out in steel pans, each holding about 10 to $11 \mathrm{~kg}$ of dry aggregate for every $25.4 \mathrm{~mm}$ ( 1 in.) thickness for the binder and base mixtures. For surface mixtures, two pans of aggregate were batched out, each holding about 7 to 8 $\mathrm{kg}$ of dry aggregate for every $19 \mathrm{~mm}(0.75 \mathrm{in}$.) thickness. The pans of aggregate were placed in a forced draft oven and heated to the mixing temperature. When the mixing temperature was achieved, the aggregate and required amount of asphalt were combined 
and mixed using a mechanical drum mixer shown in Figure 5.16. After mixing, the mixture was placed in a pan and cured at $145^{\circ} \mathrm{C}$ for 30 to 60 minutes in the forced draft oven prior to compaction process.

The linear compactor, as previously shown (Figure 5.2) was fabricated for sample preparation in this study. Procedures for using the linear compactor are as follows:

1. preheat the mold to about $145^{\circ} \mathrm{C}$ by using an infrared heater,

2. place a filter paper at the bottom of the mold and then load the batches of mixture, carefully leveling the mix,

3. place in consecutive order on the leveled mixture another piece of filter paper, a galvanized sheet metal plate, and the set of kneading plates,

4. lower the loading frame and connect the hydraulic ram,

5. lower the side cage panels and start compaction,

6. compact the specimen to the desired thickness,

7. allow the specimen to cool for about 2 to 3 hours,

8. remove the specimen from the mold and cut the specimen in half, resulting in two test specimens,

9. dry the specimens at room temperature, weigh and measure the length, width and thickness at eight locations (two on each edge), and

10. compute the volumetric density and voids relations.

Each half of the slab is placed in the wheel tracking device and grouted in place with plaster-of-Paris. After the plaster cures for about 30 minutes, the hood is closed and 
the control program is initiated. The following information is entered in the program for regular test conditions:

1. Type of test (wet or dry),

2. Test temperature $\left(60^{\circ} \mathrm{C}\right.$ for surface, $57.5^{\circ} \mathrm{C}$ for binder, and $54^{\circ} \mathrm{C}$ for base mixtures),

3. Pneumatic tire pressure (793 kpa inflation pressure),

4. Wheel path (Fixed for these tests),

5. Total mass in load box ( $85 \mathrm{~kg}$ for surface and binder mixtures, $56 \mathrm{~kg}$ for base mixtures)

6. Deformation measurements ( average of 9 points near the center of the sample, $10 \mathrm{~mm}$ between each measure point),

7. Data recording frequency (every 250 wheel passes),

8. Test criteria (20,000 wheel passes or $20 \mathrm{~mm}$ deformation, or soonest), and

9. Conditioning time ( 20 minutes for wet testing and 60 minutes for dry testing after reaching target test temperature) after the specimens reaching the target temperature.

During the test, data are displayed on the monitor including number of wheel passes, deformation for each sample and elapsed test time. The control program ends the test based on the above test criteria. The data file can be transferred to any spreadsheet software for analysis and graphical presentation. 


\subsection{Results and Analysis}

\subsubsection{Wheel Track Testing Evaluation}

Permanent deformation on the pavement surface usually includes two different modes. According to Huang (1995), these two modes are compactive deformation and plastic deformation. The first mode (compactive) is identified where the deformed surface is lower than the initial pavement surface. This type of deformation occurs in the wheel path. The second mode (plastic) is where the deformed surface that is higher than the original surface. It is often referred to as "heave" and occurs between and outside the wheel path. Rutting data recorded during PURWheel tests included only the compactive deformation. Total or "stringline" rutting is measured manually after completion of each test. Difference in the total rut and compactive rutting is the plastic or "heave" rutting component. A relationship was developed between the wheel track "rutting" (compactive deformation) and total rutting (rut depth). This relation has a goodness of fit of 0.96 . The relationship is:

Rut Depth $=0.0153$ (Deformation) ${ }^{2}+1.3144$ (Deformation)

where:

Deformation $=$ Rut depth recorded by the transducer, $\mathrm{mm}$

Rut Depth $=$ Total rut depth measurement under the straight-edge, $\mathrm{mm}$ 
Figure 5.16 illustrates the relationship between PURWheel deformation data and measured rut depth. A rut depth level of $12.7 \mathrm{~mm}$ was adopted for evaluating the rutting potential of the mix. It is equal to an $8.9 \mathrm{~mm}$ wheel track rut depth using equation 5.2 . The $8.9 \mathrm{~mm}$ wheel track rut depth allows for the relative performance evaluation of mixtures tested at the same temperature. This number was selected because it is possible to retain water on a highway surface creating hydroplaning potential (Shahin and Kohn, 1979). Experience also shows that once the rut depth exceed $15 \mathrm{~mm}$ wheel path cracking is likely. This creates an access for water and accelerates failure (Croney, 1991)

\subsubsection{Results and Analysis for The Surface Mixtures}

Results from laboratory wheel tests are shown in Figure 5.17 to Figure 5.21. Triplicate samples were prepared and tested to included the effect of sample variation. The summary of deformation rates is shown in Table 5.1. These rates were calculated by determining the number of wheel passes resulting in a $12.7 \mathrm{~mm}$ rut depth. From test results, it is obvious that damage occurs much faster with wet conditions. Also, temperature is an important factor in rutting. None of those surface mixtures finished 20,000 wheel passes in the PURWheel tests. All three surface mixes showed almost a straight deformation curve without a creep deformation stage. This shows that the mix has already lost its structural integrity and can not resist the $620 \mathrm{kPa}$ tire loading. A high amount of natural sand utilized in the \#11 surface mix may cause a progressively poor performance. 
An analysis of variance (ANOVA) was performed on PURWheel test results to determine the significance of certain factors and/or interactions of factors. The class level information is illustrated in Table 5.2 and Table 5.4. Table 5.3 and Table 5.5 list the summaries of the General Linear Models (GLM) analysis. Independent variables in the analysis were types of aggregate (AGG), types of treatments (TREAT), moisture conditions (MOISTURE), and air void content (AIRVOID). Each independent variables had 3,3 , and 2 levels, respectively. The dependent variable was the wheel passes to reach a $12.7 \mathrm{~mm}$ rut (WPASS). Due to the incomplete experimental design for all combinations of factors investigated, the statistical analyses were performed among two sub-blocks of the experimental design that were complete for some combinations of the factors.

The GLM analysis indicated that the main effects, type of aggregate and air void content, both had significant effect on the rate of rutting. The analysis also shows that moisture conditioning and antistripping agents are significant in the test.

A Tukey's Studentized Range (HSD) Test was also performed to examine variability among types of aggregate as well as the effect of treatment on the number of wheel passes. Table 5.6 and Table 5.7 shows a summary of the statistical analysis. It indicates that rate of rutting for dolomite mixtures is higher than limestone and slag mixtures. Results also indicate that only hydrated lime improved the rutting performance for the \#11 dolomite surface mixtures. The interaction effects mean with higher air void content progressively poorer performance can be expected when combined with moisture. Hydrated lime treatment mitigates the poorer performance. The dolomite mix was used 
in a highway pavement project (Interstate I-64) and exhibited significant rutting/stripping problems in less than three years (Figure 5.30).

\subsubsection{Results and Analysis for \#8 Binder Mixtures}

Results from laboratory wheel tests are shown in Figure 5.22 to Figure 5.26. Triplicate samples were prepared and tested to included the effect of sample variation. Data for rate of deformation at $12.7 \mathrm{~mm}$ rut depth are shown in Table 5.8. Compared to \#11 surface mixtures \#8 binder mixtures perform better. For example, the \#8 slag binder mixture all had less than $5 \mathrm{~mm}$ deformation after 20,000 wheel passes.

Analysis of variance (ANOVA) of \#8 binder mixture results included as independent variables types of aggregate (AGG), types of treatments (TREAT), moisture conditions (MOISTURE), and air void content (AIRVOID). Each independent variable had 3, 3, and 2 levels, respectively. The class level information is illustrated in Table 5.9 and Table 5.11. The dependent variable was the wheel passes to reach a $12.7 \mathrm{~mm}$ rut (WPASS). Table 5.10 and Table 5.12 shows results of the General Linear Models (GLM) analysis. No effects are significant at 95 percent confidence level. However, types of aggregate were significant at 90 percent level. The analysis also showed that air void content, moisture condition, and antistripping agents were not significant. The latter confirms the AASHTO T-283 test results discussed in Chapter Four.

A Tukey's Studentized Range (HSD) Test was performed to examine variability among types of aggregate on the number of wheel passes. Table 5.13 show a summary of 
the statistical analysis. It indicates that the slag mixtures were more rut resistance than the gravel and limestone mixtures.

\subsubsection{Results and Analysis for Base Mixtures}

Results from laboratory wheel tests of $\# 5 \mathrm{C}$ base mixtures are shown in Figure 5.27 to Figure 5.29. Triplicate samples were prepared and tested to included the effect of sample variation. A lower rutting criteria of $6.35 \mathrm{~mm}$ was utilized to evaluate base mixtures because the overall level of rutting for these mixtures was less than surface and binder mixtures. Data for rate of deformation at the $6.35 \mathrm{~mm}$ rut depth are also shown in Table 5.14. The $\# 5 \mathrm{C}$ base mixtures show good rutting/stripping performance with some mixtures having less than $5 \mathrm{~mm}$ deformation after 20,000 wheel passes.

Independent variables in the analysis of variance (ANOVA) were types of treatments (TREAT), moisture conditions (MOISTURE). There were 3 and 2 levels, respectively. Air void content (AIRVOID) is also one of the independent variables. Each independent variables had 3,3, levels respectively. The class level information is illustrated in Table 5.15. The dependent variable was the wheel passes to reach a 6.35 mm rut (WPASS). Table 5.16 shows results of the General Linear Models (GLM) analysis. The GLM analysis indicates that moisture condition was the only significant factor in the GLM model. Other main effects and interaction effects were not significant in the GLM model. This means that moisture increases the rate of rutting. 


\section{$\underline{5.6 \text { Summary }}$}

Laboratory wheel tracking test results for all seven types of mixtures indicated that temperature and moisture conditions were significant. It is obvious that damage occurs much faster with wet conditions. Both factors are important in identifying stripping/rutting potential.

Aggregate type has a significant effect on the wheel track test results. Limestone and slag generally provided better performance than other types of aggregate in this study. Examination of the performance of Indiana \#11 surface mixture shows that a higher percentage of natural sand causes progressively poorer performance. This is not true for binder mixtures for the amount of natural sand utilized.

The effect of the antistripping agents is not significant in the test. However, a comparison of hot/wet and hot/dry test results indicates the moisture damage is associated with excessive deformation.

In this study, the dolomite mix performed poorly in both wet and dry conditions. This may be due to the high asphalt content of the \#11 dolomite surface mix itself. The dolomite mixture was reproduced from aggregates utilized on a distressed section of Indiana I-64 in the Vincennes district (Figure 5.30). Distresses in the laboratory wheel track tests were similar. Review of this mixture in-place on interstate highway I-64, the pavement exhibits similar distresses as the wheel track testing samples revealed. A field investigation is needed to correlate laboratory test results to the actual field performance. 
Table 5.1 \# 11 Surface Wheel Track Test Results Summary (Wheel Passes @12.7 mm Rut)

\begin{tabular}{|c|c|c|c|c|c|}
\hline Types of Agg. & $\begin{array}{c}\text { Dry Test (Air } \\
\text { Voids, \%) }\end{array}$ & $\begin{array}{c}\text { Passes@6\% } \\
\text { Air Voids }\end{array}$ & $\begin{array}{l}\text { Wet Test (Air } \\
\text { Voids, \%) }\end{array}$ & $\begin{array}{c}\text { Passes @6\% } \\
\text { Air Voids }\end{array}$ & $\begin{array}{l}\text { Wet/Dry } \\
\text { Ratio }\end{array}$ \\
\hline \multirow{3}{*}{ \#11 Slag } & $3750(5.79)$ & \multirow{3}{*}{3371} & $1550(6.79)$ & \multirow{3}{*}{1138} & \multirow{3}{*}{0.34} \\
\hline & $2650(6.53)$ & & $1070(6.01)$ & & \\
\hline & $1900(8.12)$ & & $660(6.92)$ & & \\
\hline \multirow{3}{*}{ \#11 Limestone } & $2600(4.17)$ & \multirow{3}{*}{2535} & $1300(4.24)$ & \multirow{3}{*}{1477} & \multirow{3}{*}{0.58} \\
\hline & $5170(3.44)$ & & $1840(3.64)$ & & \\
\hline & $2850(6.03)$ & & $1290(4.55)$ & & \\
\hline \multirow{3}{*}{ \#11 Dolomite } & $350(4.59)$ & \multirow{3}{*}{585} & $291(4.03)$ & \multirow{3}{*}{146} & \multirow{3}{*}{0.25} \\
\hline & $82(8.53)$ & & $108(6.44)$ & & \\
\hline & $70(8.96)$ & & $133(6.25)$ & & \\
\hline \multirow{3}{*}{ \#11 Dolomite w/ Chemical } & $375(4.98)$ & \multirow{3}{*}{231} & $333(3.55)$ & \multirow{3}{*}{223} & \multirow{3}{*}{0.97} \\
\hline & $150(6.81)$ & & $310(5.66)$ & & \\
\hline & $107(6.65)$ & & $128(6.95)$ & & \\
\hline \multirow{3}{*}{ \#11 Dolomite w/ Lime } & $1040(3.10)$ & \multirow{3}{*}{296} & $600(2.83)$ & \multirow{3}{*}{291} & \multirow{3}{*}{0.98} \\
\hline & $330(5.84)$ & & $250(6.49)$ & & \\
\hline & $130(6.67)$ & & $200(6.88)$ & & \\
\hline
\end{tabular}


Table 5.2 Class Level Information-\#11 Dolomite Surface Mix

\begin{tabular}{|c|c|c|c|c|}
\hline Class & Levels & \multicolumn{3}{|c|}{ Values } \\
\hline TREAT & 3 & CONTROL & CHEMICAL & LIME \\
\hline MOISTURE & 2 & DRY & WET & \\
\hline \multicolumn{4}{|l}{ Number of observations in data set $=18$} \\
\hline
\end{tabular}

Table 5.3 Summary of Statistical Analysis for \#11 Dolomite Surface Mixtures

\begin{tabular}{|l|c|c|c|c|c|}
\hline \multicolumn{7}{|l|}{ Dependent Variable: WPASS } \\
\hline Source & df & SS & MS & F stat & Prob. > F \\
\hline Model & 11 & 924744.60 & 84067.69 & 52.63 & 0.0001 \\
\hline Error & 6 & 9584.35 & 1597.39 & & \\
\hline Total & 17 & 934328.94 & & & \\
\hline \multicolumn{7}{|l|}{} & R-Square & Adj. R-Sq. & Root MSE & Mean \\
\cline { 2 - 6 } & 0.99 & 0.97 & 39.97 & 277.06 \\
\hline \multicolumn{5}{|l|}{} \\
\hline Source & df & Type 1 SS & MS & F stat & Prob. > F \\
\hline TREAT & 2 & 76264.18 & 38132.09 & 23.87 & 0.0014 \\
\hline MOISTURE & 1 & 56412.06 & 56412.06 & 35.32 & 0.0010 \\
\hline AIRVOID & 1 & 578401.75 & 578401.75 & 362.09 & 0.0001 \\
\hline AIRVOID*TREAT & 2 & 90413.49 & 45206.74 & 28.30 & 0.0009 \\
\hline AIRVOID*MOISTURE & 1 & 70896.36 & 70896.36 & 44.38 & 0.0006 \\
\hline TREAT*MOISTURE & 2 & 6536.64 & 3268.32 & 2.05 & 0.2101 \\
\hline $\begin{array}{l}\text { AIRVOID*TREAT } \\
\text { *MOISTURE }\end{array}$ & 2 & 45820.12 & 22910.06 & 14.34 & 0.0052 \\
\hline
\end{tabular}


Table 5.4 Class Level Information-\#11 Surface Mix

\begin{tabular}{|c|c|c|c|c|}
\hline Class & Levels & \multicolumn{3}{|c|}{ Values } \\
\hline AGG & 3 & DOLOMITE & LIMESTONE & SLAG \\
\hline MOISTURE & 2 & DRY & WET & \\
\hline \multicolumn{5}{|l}{ Number of observations in data set $=18$} \\
\hline
\end{tabular}

Table 5.5 Summary of Statistical Analysis for \#11 Surface Mixtures Dependent Variable: WPASS

\begin{tabular}{|l|c|c|c|c|c|}
\hline Source & df & SS & MS & F stat & Prob. > F \\
\hline Model & 11 & 31877199.80 & 2897927.26 & 6.02 & 0.0192 \\
\hline Error & 6 & 2883563.97 & 480593.99 & & \\
\hline Total & 17 & 34760763.80 & & & \\
\hline \multicolumn{7}{|c|}{} & R-Square & Adj. R-Sq. & Root MSE & Mean \\
\cline { 2 - 7 } & 0.92 & 0.77 & 693.25 & 1536.89 \\
\hline Source & df & Type 1 SS & MS & F stat & Prob. > F \\
\hline AGG & 2 & 13056942.50 & 6528471.23 & 13.58 & 0.0059 \\
\hline MOISTURE & 1 & 9351038.03 & 9351038.03 & 19.46 & 0.0045 \\
\hline AIRVOID & 1 & 5311915.71 & 5311915.71 & 11.05 & 0.0159 \\
\hline AIRVOID*AGG & 2 & 617163.60 & 308581.80 & 0.6421 & 0.5589 \\
\hline AIRVOID*MOISTURE & 1 & 545393.91 & 545393.91 & 1.13 & 0.3277 \\
\hline AGG*MOISTURE & 2 & 2831896.18 & 1415948.09 & 2.95 & 0.1284 \\
\hline $\begin{array}{l}\text { AIRVOID*AGG } \\
\text { *MOISTURE }\end{array}$ & 2 & 162849.92 & 81424.96 & 0.17 & 0.8481 \\
\hline
\end{tabular}


Table 5.6 Mean Comparison of wheel Passes for Different Aggregate Types(\#11 Surface)

\begin{tabular}{|l|c|c|c|}
\hline \multicolumn{1}{|c|}{ Aggregate } & Mean & N & Tukey Grouping \\
\hline Limestone & 2508.3 & 6 & A \\
\hline Slag & 1930.0 & 6 & A \\
\hline Dolomite & 172.3 & 6 & B \\
\hline Alpha $=0.05, \mathrm{df}=6$, MSE $=480594$ & \\
Critical Value of Studentized Range $=4.339$ & \\
Min. Significant Difference $=1228$
\end{tabular}

Table 5.7 Mean Comparison of Wheel Passes for Different Treatments (\#11 Dolomite)

\begin{tabular}{|l|c|c|c|}
\hline \multicolumn{1}{|c|}{ Treatment } & Mean & N & Tukey Grouping \\
\hline Hydrated Lime & 425.0 & 6 & $\mathrm{~A}$ \\
\hline Liquid Additive & 233.8 & 6 & $\mathrm{~B}$ \\
\hline Control & 172.3 & 6 & $\mathrm{~B}$ \\
\hline Alpha $=0.05, \mathrm{df}=6, \mathrm{MSE}=1597.391$ & \\
Critical Value of Studentized Range $=4.339$ \\
Min. Significant Difference $=70.798$
\end{tabular}


Table 5.8 \# 8 Binder Wheel Track Test Results Summary (Wheel Passes@12.7 mm Rut)

\begin{tabular}{|c|c|c|c|c|c|}
\hline Types of Agg. & $\begin{array}{l}\text { Dry Test (Air } \\
\text { Voids, \%) }\end{array}$ & $\begin{array}{c}\text { Passes @ 6\% } \\
\text { air Voids }\end{array}$ & $\begin{array}{l}\text { Wet Test (Air } \\
\text { Voids, \%) }\end{array}$ & $\begin{array}{c}\text { Passes @ 6\% } \\
\text { air Voids }\end{array}$ & $\begin{array}{c}\text { Wet/Dry } \\
\text { Ratio }\end{array}$ \\
\hline \multirow{3}{*}{ \#8 Slag } & $582888(6.71)$ & \multirow{3}{*}{332742} & $63549(6.22)$ & \multirow{3}{*}{73860} & \multirow{3}{*}{0.22} \\
\hline & $85117(7.36)$ & & $152863(4.40)$ & & \\
\hline & $296965(4.91)$ & & $97777(4.15)$ & & \\
\hline \multirow{3}{*}{ \#8 Limestone } & $12000(4.17)$ & \multirow{3}{*}{11650} & $14250(5.88)$ & \multirow{3}{*}{11527} & \multirow{3}{*}{0.99} \\
\hline & $9500(6.15)$ & & $3750(7.12)$ & & \\
\hline & $8000(6.87)$ & & $2500(8.99)$ & & \\
\hline \multirow{3}{*}{ \#8 Gravel } & $8000(6.87)$ & \multirow{3}{*}{16358} & $9000(9.75)$ & \multirow{3}{*}{8544} & \multirow{3}{*}{0.52} \\
\hline & $13000(4.87)$ & & $8500(5.64)$ & & \\
\hline & $31502(5.53)$ & & $2250(6.63)$ & & \\
\hline \multirow{3}{*}{ \#8 Gravel w/ Chemical } & $10750(4.73)$ & \multirow{3}{*}{7644} & $4500(7.53)$ & \multirow{3}{*}{7785} & \multirow{3}{*}{1.02} \\
\hline & $4000(4.87)$ & & $9250(5.71)$ & & \\
\hline & $8000(6.19)$ & & $4750(6.62)$ & & \\
\hline \multirow{3}{*}{$\# 8$ Gravel w/ Lime } & $10750(4.52)$ & \multirow{3}{*}{5833} & $14000(5.17)$ & \multirow{3}{*}{10616} & \multirow{3}{*}{1.82} \\
\hline & $3750(5.67)$ & & $11000(6.20)$ & & \\
\hline & $6500(6.43)$ & & $8500(5.40)$ & & \\
\hline
\end{tabular}


Table 5.9 Class Level Information-\#8 Gravel Mix

\begin{tabular}{|l|c|c|c|c|}
\hline Class & Levels & & Values \\
\hline TREAT & 3 & CONTROL & CHEMICAL & LIME \\
\hline MOISTURE & 2 & DRY & WET & \\
\multicolumn{5}{|l}{ Number of observations in data set $=18$} \\
\hline
\end{tabular}

Table 5.10 Summary of Statistical Analysis for \#8 Gravel Mixtures

\begin{tabular}{|l|c|c|c|c|c|}
\hline \multicolumn{7}{|l|}{ Dependent Variable: WPASS } \\
\hline Source & df & SS & MS & F stat & Prob. $>$ F \\
\hline Model & 11 & 254798511.0 & 23163501.0 & 0.7035 & 0.7102 \\
\hline Error & 6 & 197562601.0 & 32927100.1 & & \\
\hline Total & 17 & 452361111.0 & & & \\
\hline & & R-Square & Adj. R-Sq. & Root MSE & Mean \\
\cline { 2 - 7 } & 0.5633 & 0 & 5738.21 & 8972.22 \\
\hline \multicolumn{5}{|l|}{} \\
\hline Source & df & Type 1 SS & MS & F stat & Prob. > F \\
\hline TREAT & 2 & 73524503.20 & 36762251.60 & 1.12 & 0.3871 \\
\hline MOISTURE & 1 & 1212040.88 & 1212040.88 & 0.0368 & 0.8542 \\
\hline AIRVOID & 1 & 31527207.80 & 31527207.80 & 0.96 & 0.3656 \\
\hline AIRVOID*TREAT & 2 & 2127113.85 & 1063556.93 & 0.0323 & 0.9684 \\
\hline AIRVOID*MOISTURE & 1 & 2291304.91 & 2291304.91 & 0.0696 & 0.8008 \\
\hline TREAT*MOISTURE & 2 & 116471029.00 & 58235514.30 & 1.7686 & 0.2490 \\
\hline $\begin{array}{l}\text { AIRVOID*TREAT } \\
* \text { MOISTURE }\end{array}$ & 2 & 27645311.20 & 13822655.60 & 0.4198 & 0.6751 \\
\hline
\end{tabular}


Table 5.11 Class Level Information-\#8 Binder Mix

\begin{tabular}{|l|c|c|c|c|}
\hline \multicolumn{1}{|c|}{ Class } & Levels & \multicolumn{3}{|c|}{ Values } \\
\hline AGG & 3 & GRAVEL & LIMESTONE & SLAG \\
\hline MOISTURE & 2 & DRY & WET & \\
\multicolumn{4}{|l}{ Number of observations in data set $=18$} \\
\end{tabular}

Table 5.12 Summary of Statistical Analysis for \#8 Binder Mixtures

\begin{tabular}{|c|c|c|c|c|c|}
\hline \multicolumn{6}{|c|}{ Dependent Variable: WPASS } \\
\hline Source & $\mathrm{df}$ & SS & MS & F stat & Prob. > F \\
\hline Model & 11 & $2.416 \mathrm{E}+11$ & $2.196 \mathrm{E}+10$ & 1.0681 & 0.4931 \\
\hline Error & 6 & $1.234 \mathrm{E}+11$ & $2.056 \mathrm{E}+10$ & & \\
\hline \multirow[t]{3}{*}{ Total } & 17 & $3.650 \mathrm{E}+11$ & & & \\
\hline & & R-Square & Adj. R-Sq. & Root MSE & Mean \\
\hline & & 0.66 & 0.04 & 143394.28 & 77856.17 \\
\hline Source & $\mathrm{df}$ & Type 1 SS & MS & F stat & Prob. $>\mathrm{F}$ \\
\hline AGG & 2 & $1.589 \mathrm{E}+11$ & $7.946 \mathrm{E}+10$ & 3.8644 & 0.0835 \\
\hline MOISTURE & 1 & $3.086 \mathrm{E}+10$ & $3.086 \mathrm{E}+10$ & 1.5006 & 0.2665 \\
\hline AIRVOID & 1 & $7.410 \mathrm{E}+09$ & $7.410 \mathrm{E}+09$ & 0.3604 & 0.5703 \\
\hline AIRVOID*AGG & 2 & 401801307 & 200900653 & 0.0098 & 0.9903 \\
\hline AIRVOID*MOISTURE & 1 & $2.250 \mathrm{E}+09$ & $2.250 \mathrm{E}+09$ & 0.1094 & 0.7521 \\
\hline AGG*MOISTURE & 2 & $4.169 \mathrm{E}+10$ & $2.084 \mathrm{E}+10$ & 1.0138 & 0.4176 \\
\hline $\begin{array}{l}\text { AIRVOID*AGG } \\
\text { *MOISTURE }\end{array}$ & 2 & 57202428 & 28601214 & 0.9986 & 0.9986 \\
\hline
\end{tabular}


Table 5.13 Mean Comparison of wheel Passes for Different Aggregate Types(\#8 Binder)

\begin{tabular}{|l|c|c|c|}
\hline \multicolumn{1}{|c|}{ Aggregate } & Mean & N & Tukey Grouping \\
\hline Slag & 213193 & 6 & A \\
\hline Gravel & 12042 & 6 & B \\
\hline Limestone & 8333 & 6 & B \\
\hline $\begin{array}{l}\text { Alpha }=0.10, d f=6, \text { MSE }=1.543 E 10 \\
\text { Critical Value of Studentized Range }=3.374 \\
\text { Min. Significant Difference }=171090\end{array}$ \\
\hline
\end{tabular}

Table 5.14 \# 5C Base Wheel Track Test Results Summary (Wheel Passes@6.35 mm

$$
\text { Rut) }
$$

\begin{tabular}{|c|c|c|c|c|c|}
\hline Types of Agg. & $\begin{array}{c}\text { Dry Test (Air } \\
\text { Voids, } \%) \\
\end{array}$ & $\begin{array}{l}\text { Est. Passes @ } \\
\text { 6\% Air Voids } \\
\end{array}$ & $\begin{array}{l}\text { Wet Test (Air } \\
\text { Voids, \%) }\end{array}$ & $\begin{array}{l}\text { Est. Passes @ } \\
6 \% \text { Air Voids } \\
\end{array}$ & $\begin{array}{c}\text { Wet/Dry } \\
\text { Ratio } \\
\end{array}$ \\
\hline \multirow{3}{*}{ \#5C Limestone } & $18109(6.09)$ & \multirow{3}{*}{21616} & $7000(4.92)$ & \multirow{3}{*}{11200} & \multirow{3}{*}{0.52} \\
\hline & $26230(6.54)$ & & $11000(6.76)$ & & \\
\hline & $100860(6.44)$ & & $16000(6.44)$ & & \\
\hline \multirow{3}{*}{$\begin{array}{c}\text { \#5C Limestone } \\
\text { w/ Chemical }\end{array}$} & $18250(7.39)$ & \multirow{3}{*}{30651} & $6500(6.41)$ & \multirow{3}{*}{5833} & \multirow{3}{*}{0.19} \\
\hline & $31502(5.78)$ & & $5000(6.65)$ & & \\
\hline & $29886(7.33)$ & & $6250(6.59)$ & & \\
\hline \multirow{3}{*}{ \#5C Limestone w/ Lime } & $60915(6.12)$ & \multirow{3}{*}{110567} & $7500(5.88)$ & \multirow{3}{*}{7925} & \multirow{3}{*}{0.07} \\
\hline & $54490(6.80)$ & & $10500(7.85)$ & & \\
\hline & $143660(6.14)$ & & $10750(7.25)$ & & \\
\hline
\end{tabular}


Table 5.15 Class Level Information-\#5C Base Mix

\begin{tabular}{|l|c|c|c|c|}
\hline \multicolumn{1}{|c|}{ Class } & Levels & \multicolumn{3}{|c|}{ Values } \\
\hline TREAT & 3 & CONTROL & CHEMICAL & LIME \\
\hline MOISTURE & 2 & DRY & WET & \\
\hline \multicolumn{4}{|l}{ Number of observations in data set $=18$} \\
\hline
\end{tabular}

Table 5.16 Summary of Statistical Analysis for \#5C Base Mixtures

\begin{tabular}{|c|c|c|c|c|c|}
\hline \multicolumn{6}{|c|}{ Dependent Variable: WPASS } \\
\hline Source & $\mathrm{df}$ & SS & MS & F stat & Prob. $>\mathrm{F}$ \\
\hline Model & 9 & $1.699 \mathrm{E}+10$ & $1.887 \mathrm{E}+09$ & 2.2017 & 0.1401 \\
\hline Error & 8 & $6.857 \mathrm{E}+09$ & 857169827 & & \\
\hline Total & 17 & $2.384 \mathrm{E}+10$ & & & \\
\hline & & R-Square & Adj. R-Sq. & Root MSE & Mean \\
\hline & & 0.7124 & 0.3888 & 29277.46 & 31355.67 \\
\hline Source & $\mathrm{df}$ & Type $1 \mathrm{SS}$ & MS & F stat & Prob. $>\mathrm{F}$ \\
\hline TREAT & 2 & $2.705 \mathrm{E}+09$ & $1.353 \mathrm{E}+09$ & 1.5781 & 0.2644 \\
\hline MOISTURE & 1 & $9.272 \mathrm{E}+09$ & $9.272 \mathrm{E}+09$ & 10.8174 & 0.0110 \\
\hline AIRVOID & 1 & 717120510 & 717120510 & 0.8366 & 0.3871 \\
\hline AIRVOID*TREAT & 2 & $2.178 \mathrm{E}+09$ & $1.089 \mathrm{E}+09$ & 1.2706 & 0.3317 \\
\hline AIRVOID*MOISTURE & 1 & 78894311.1 & 78894311.1 & 0.0920 & 0.7693 \\
\hline MOISTURE*TREAT & 2 & $2.033 \mathrm{E}+09$ & $1.017 \mathrm{E}+09$ & 1.1860 & 0.3539 \\
\hline
\end{tabular}




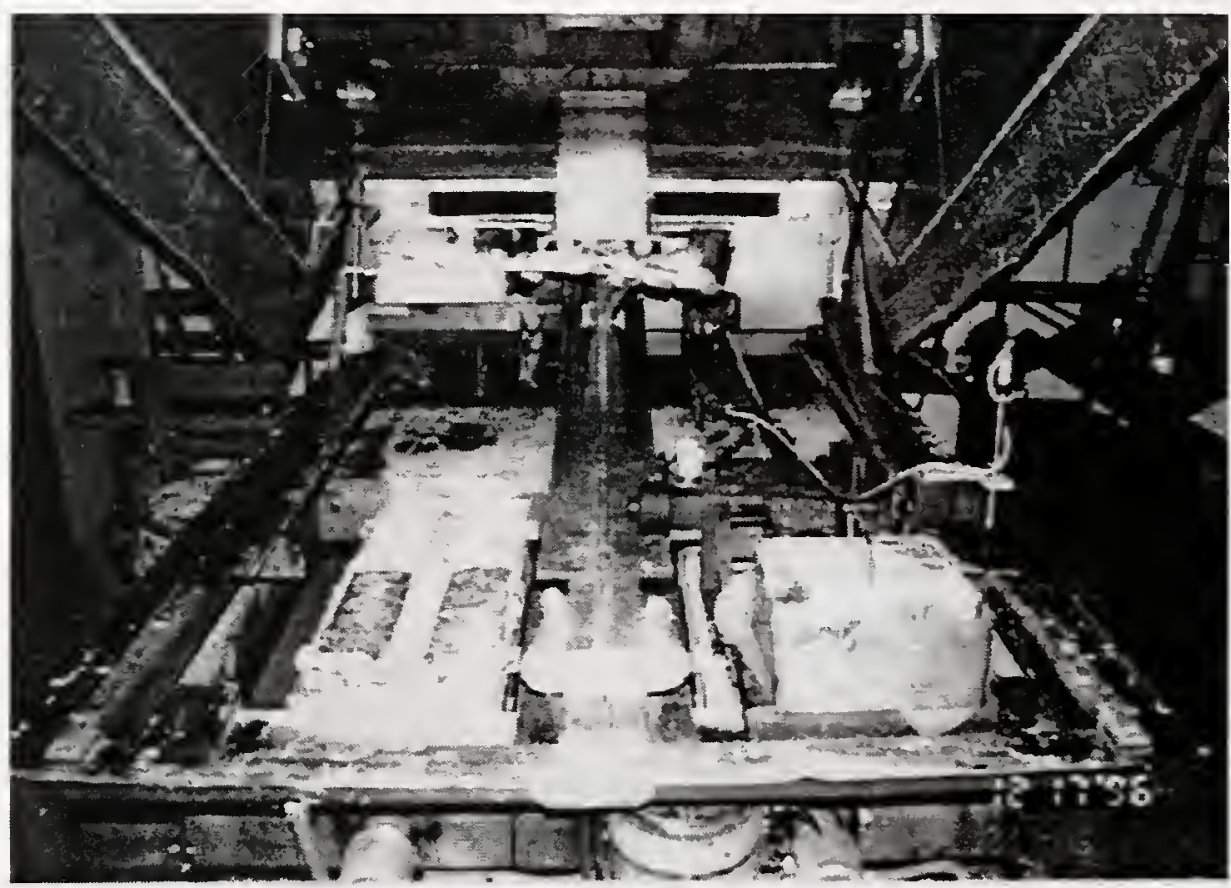

Figure 5.1 Purdue Wheel Track Testing Device 


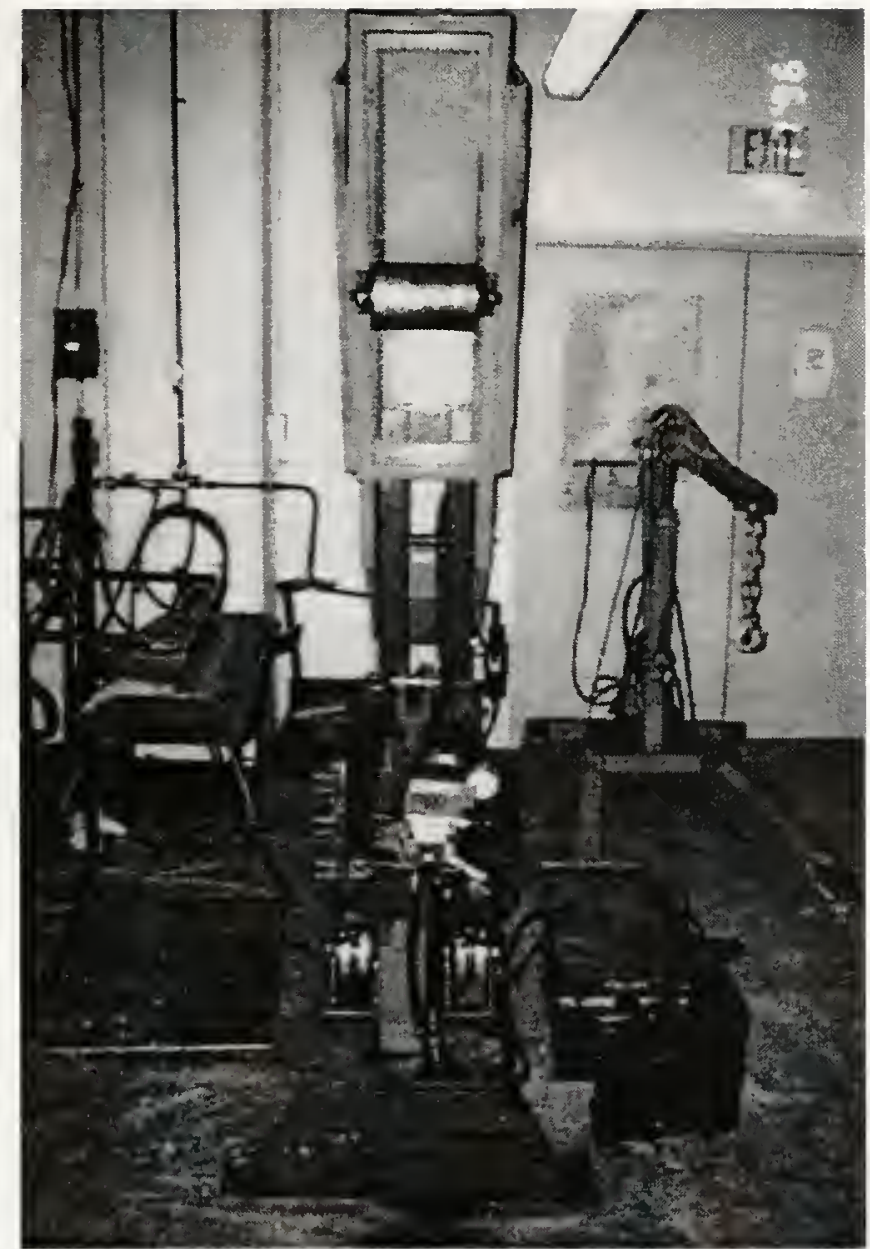

Figure 5.2 Purdue Linear Compactor 
\#8 Gravel Mix ( $70 \%$ Crushed Agg.

$50 \%$ Natural Sand )

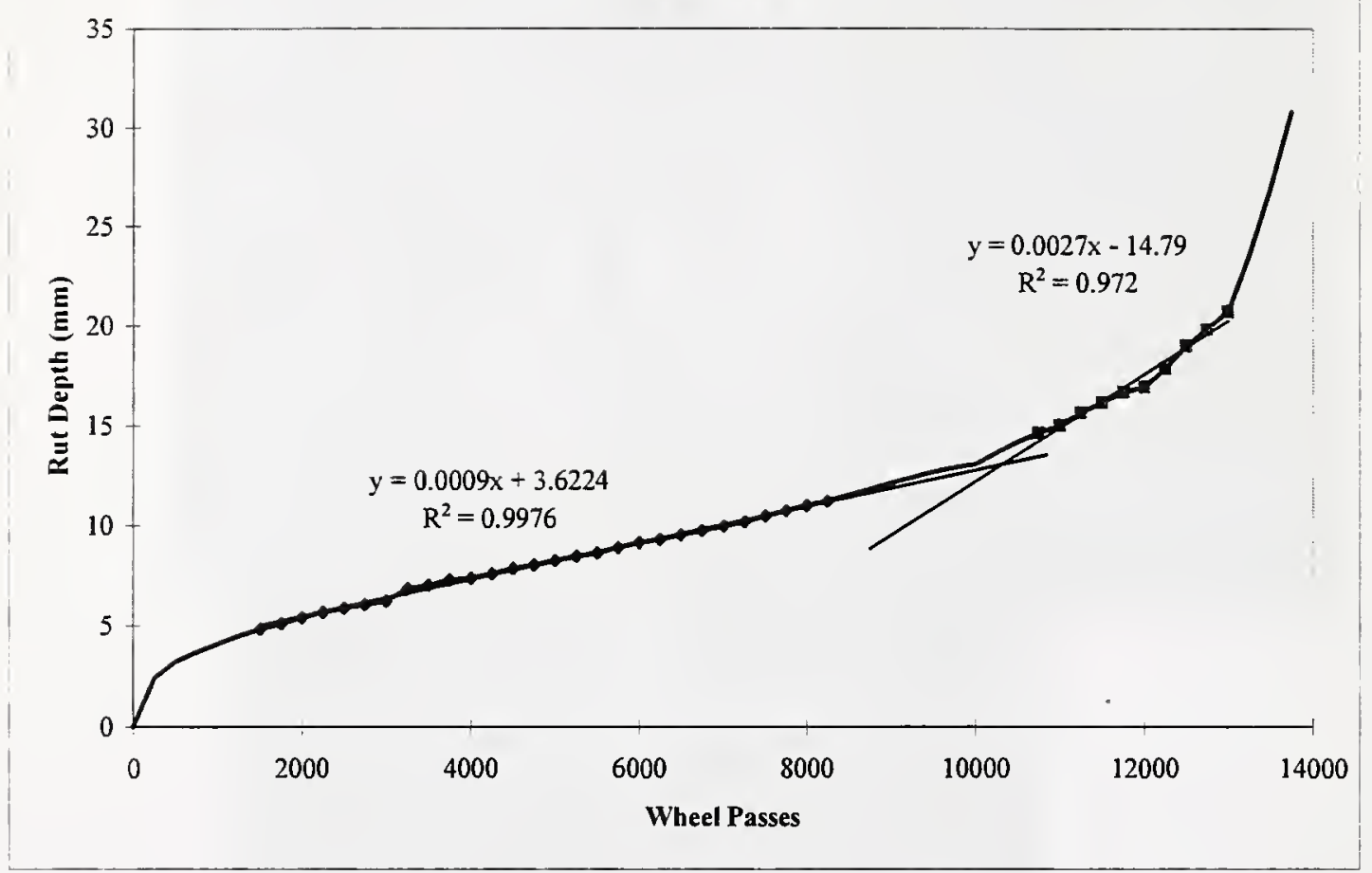

Figure 5.3 Typical PURWheel Test Results 


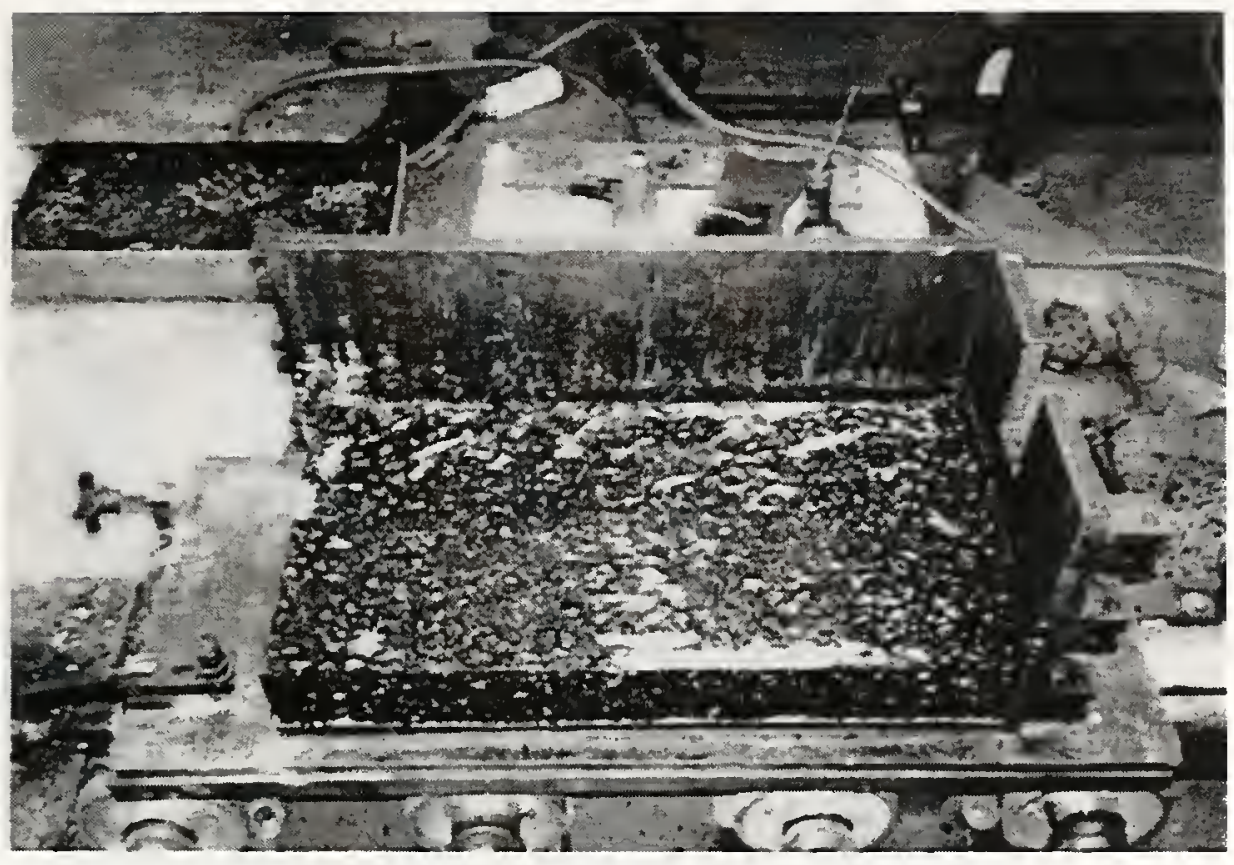

Figure 5.4 Linear Compactor Steel Mold Feature 


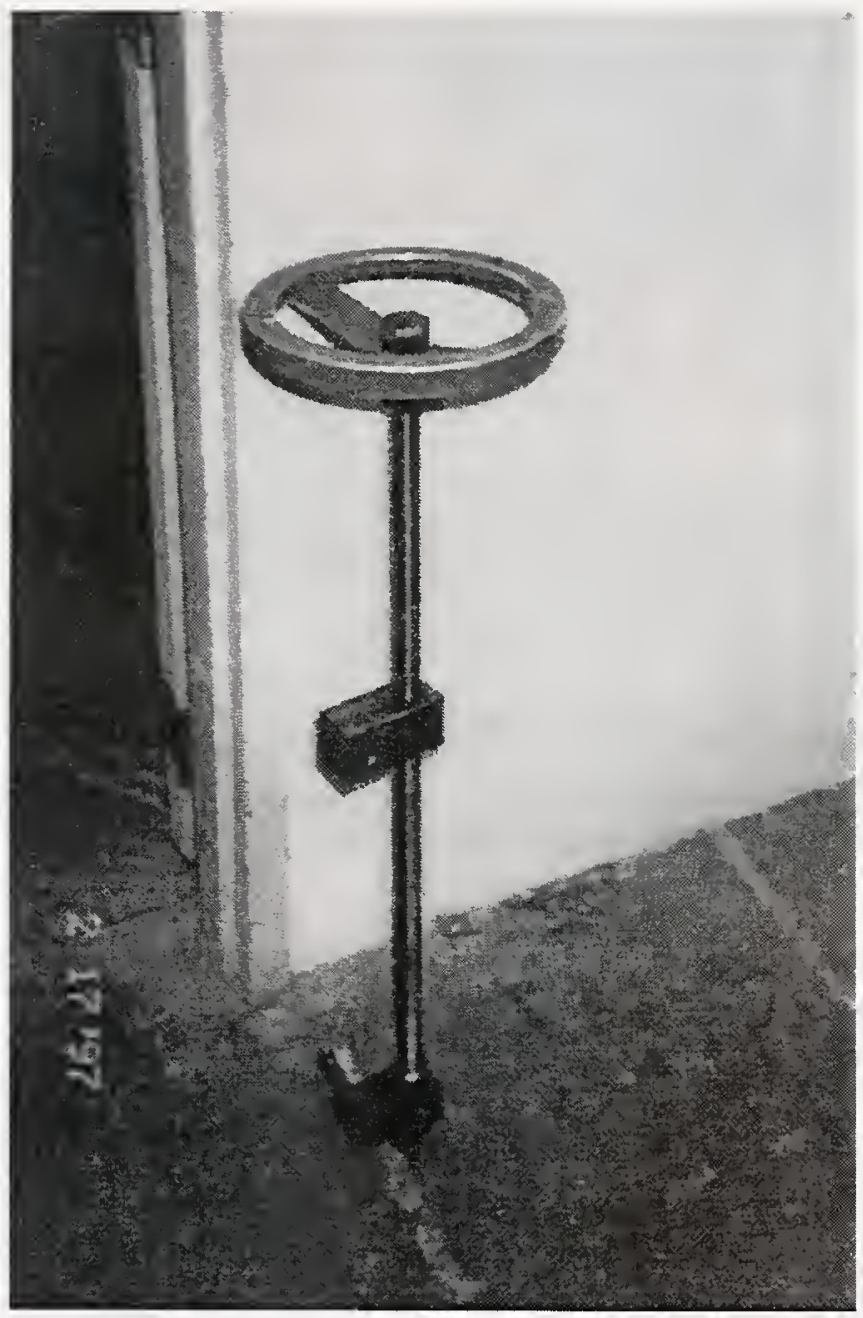

Figure 5.5 Threaded Rod 


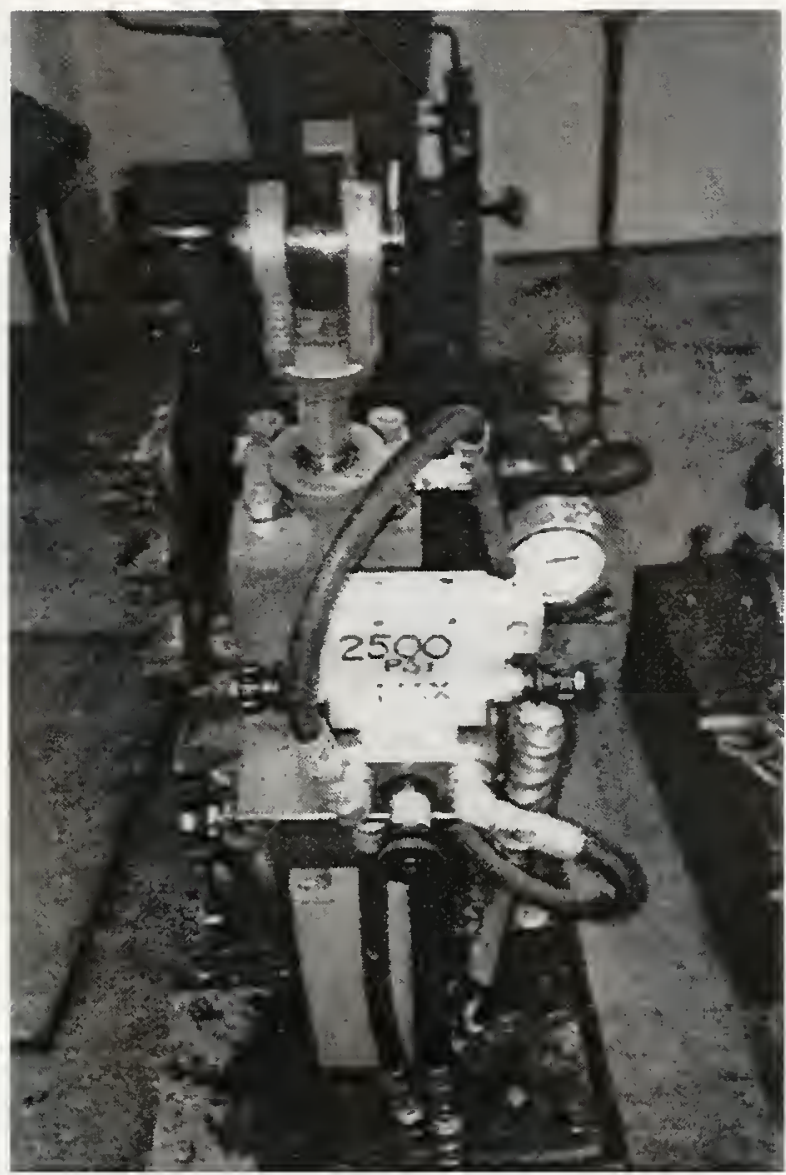

Figure 5.6 Hydraulic Loading Ram (red color) 


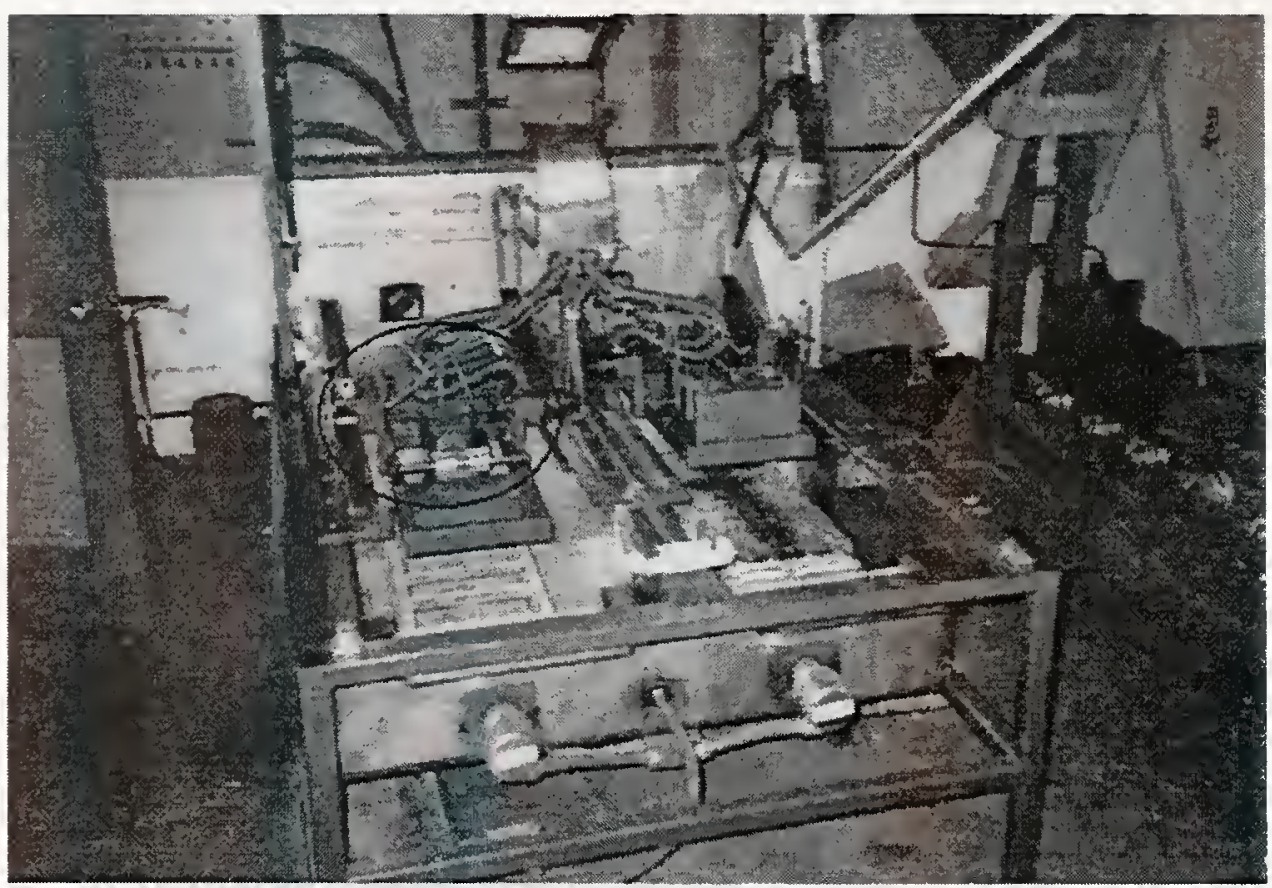

Figure 5.7 Wheel Wander Features 


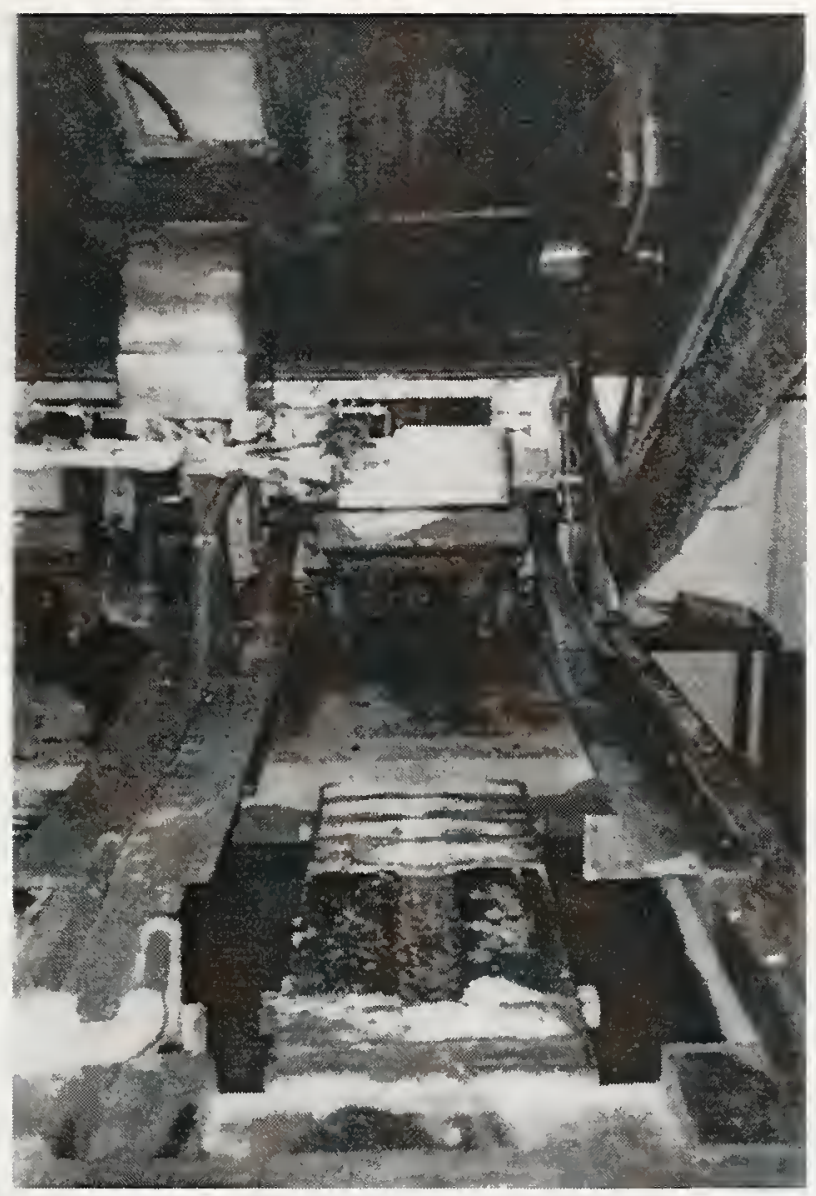

Figure 5.8 Sample Mounting Box 


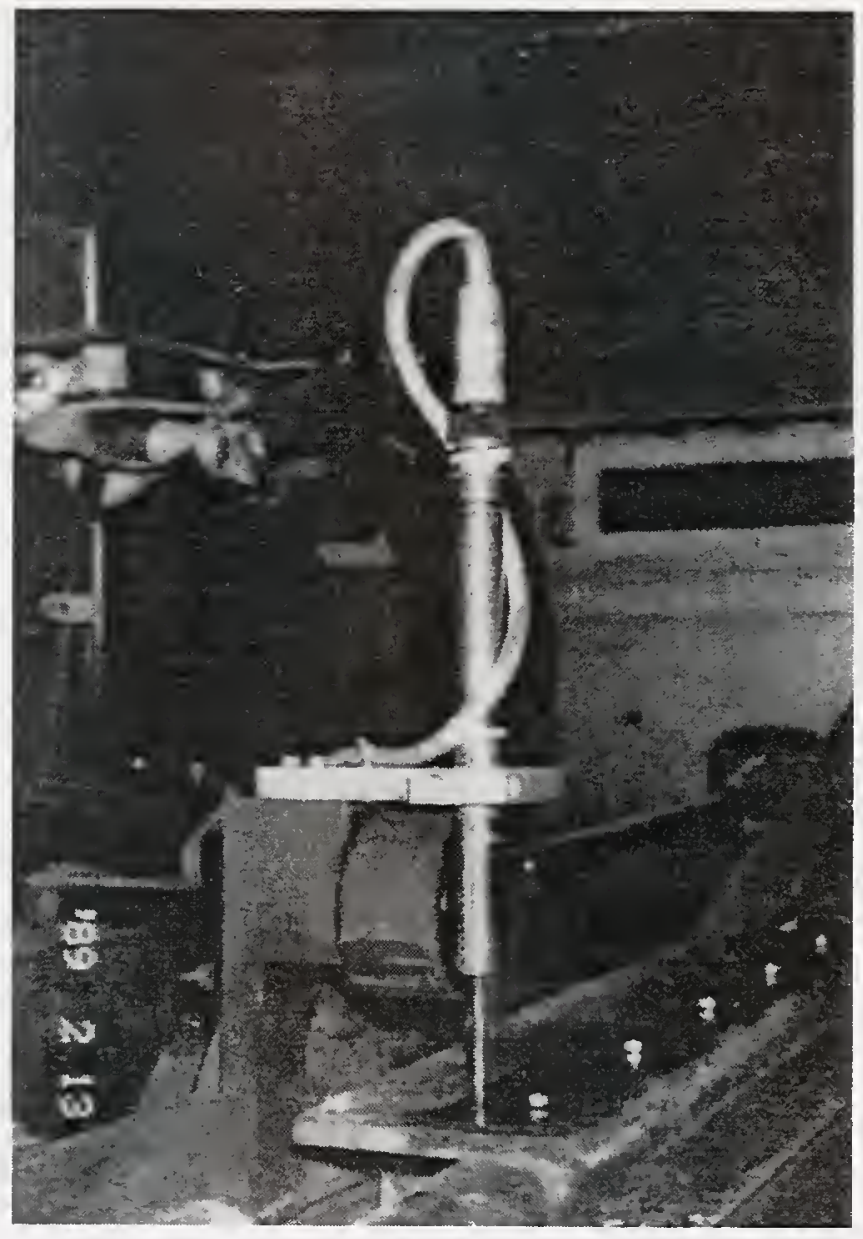

Figure 5.9 PURWheel Transducer 


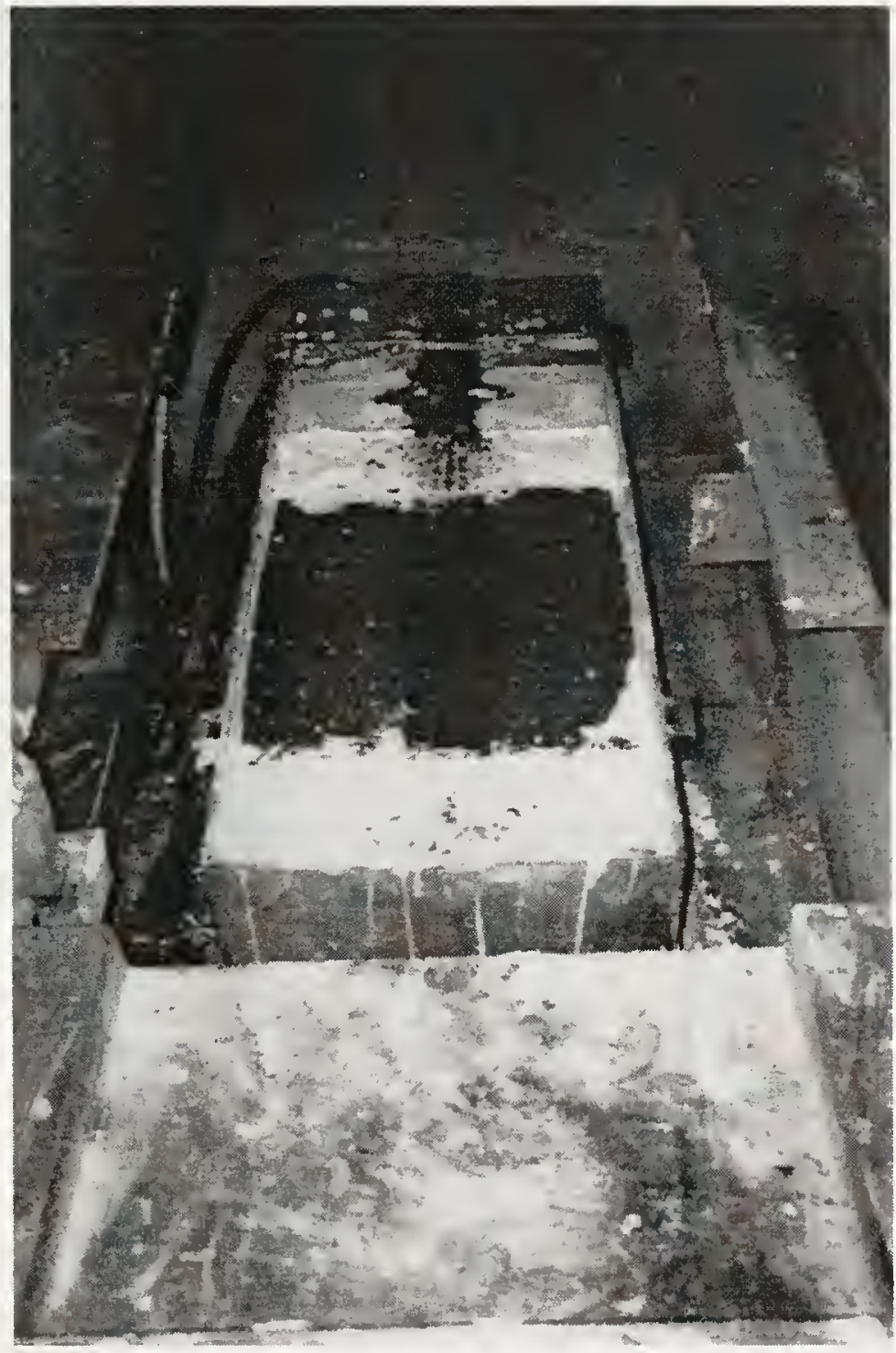

Figure 5.10 Dry Cycle Heating Box 


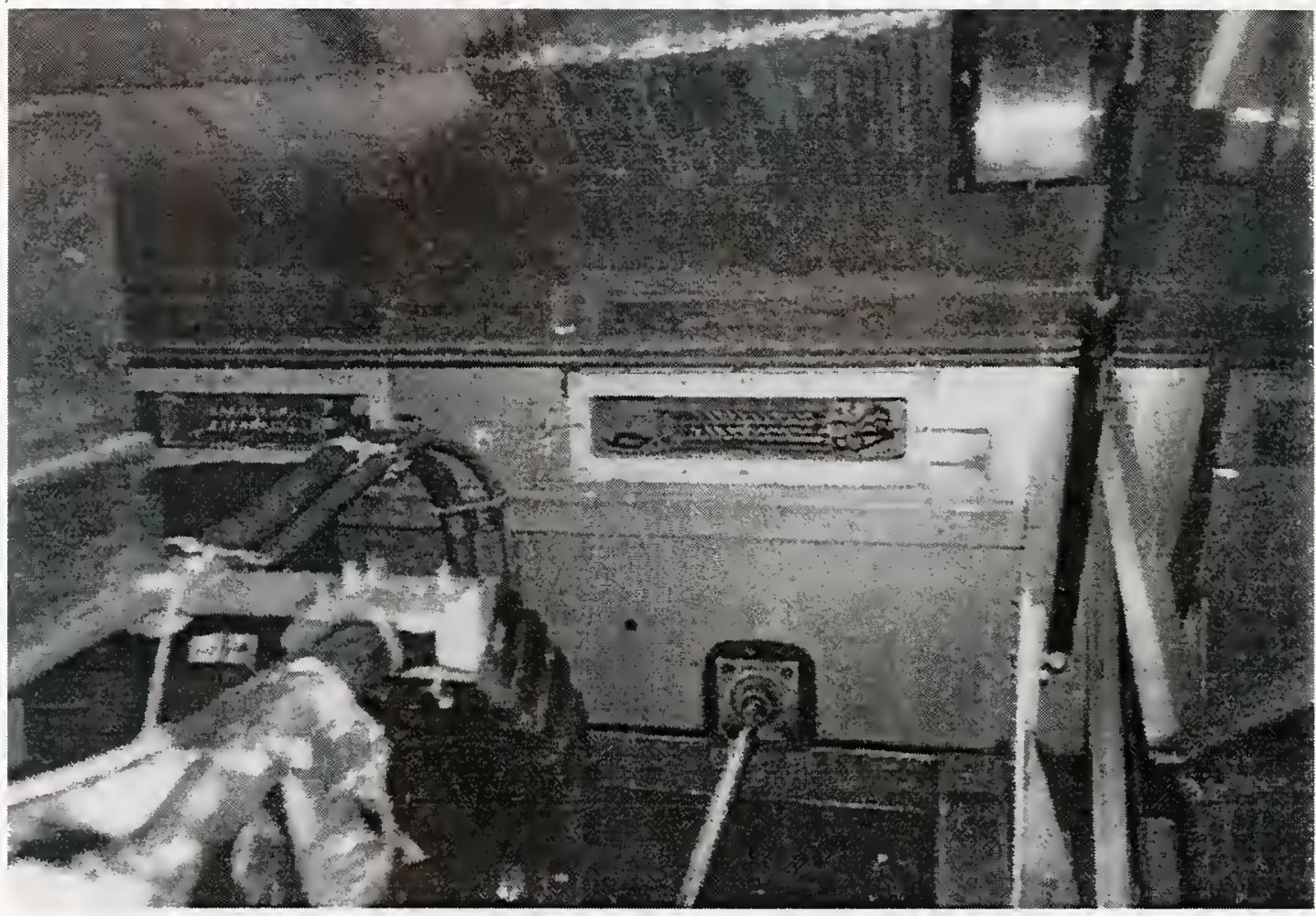

Figure 5.11 PURWheel Air Heater 


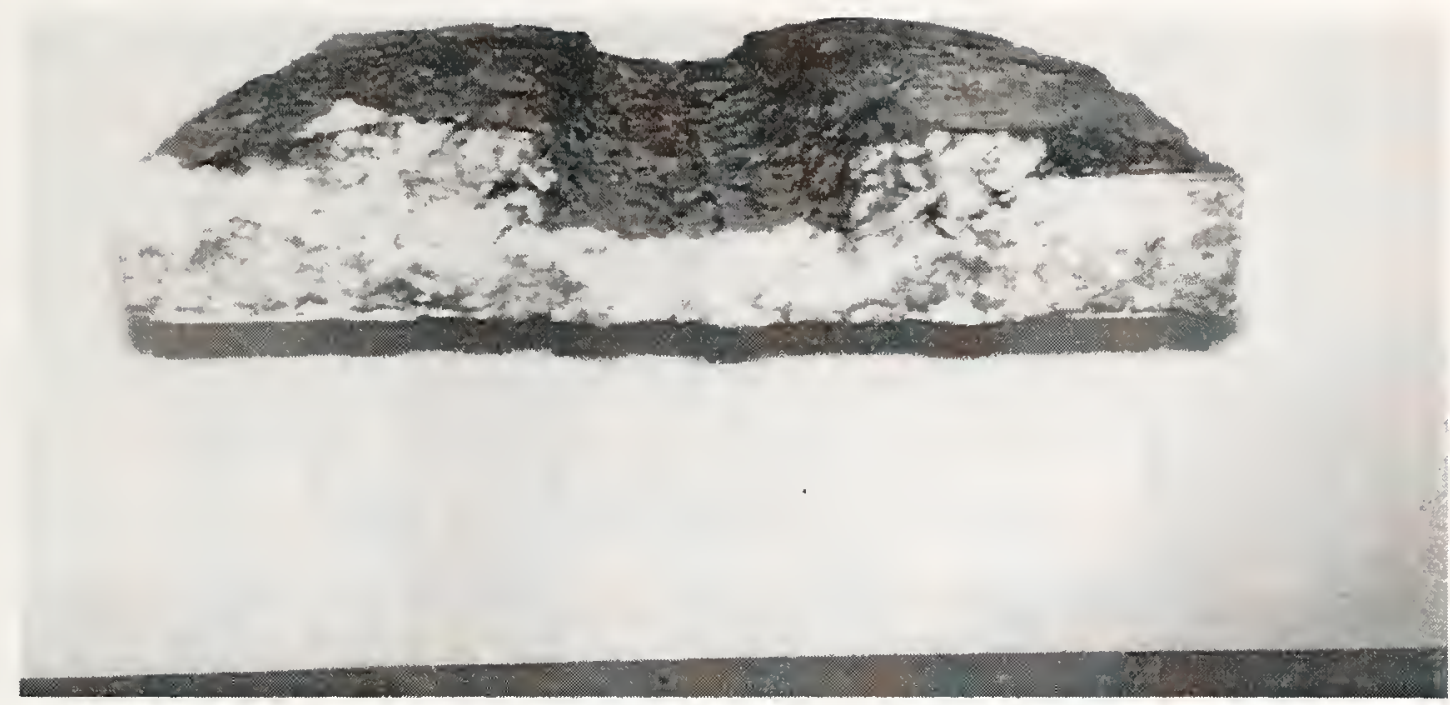

Figure 5.12 Typical Slab Section Deformation 
Stress us. Depth

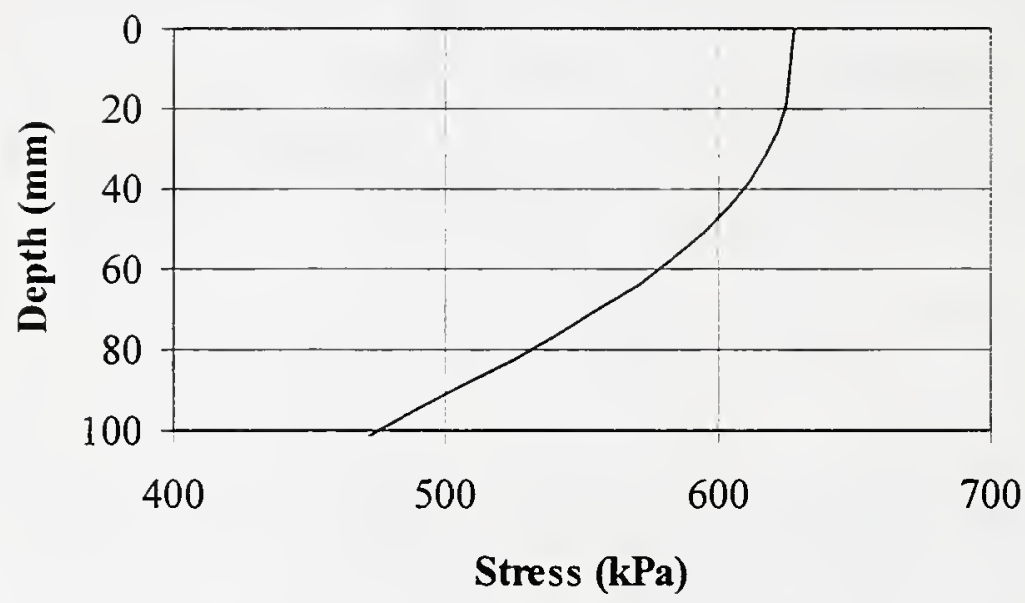

Figure 5.13 Stress vs. Depth Relationship from BISAR 


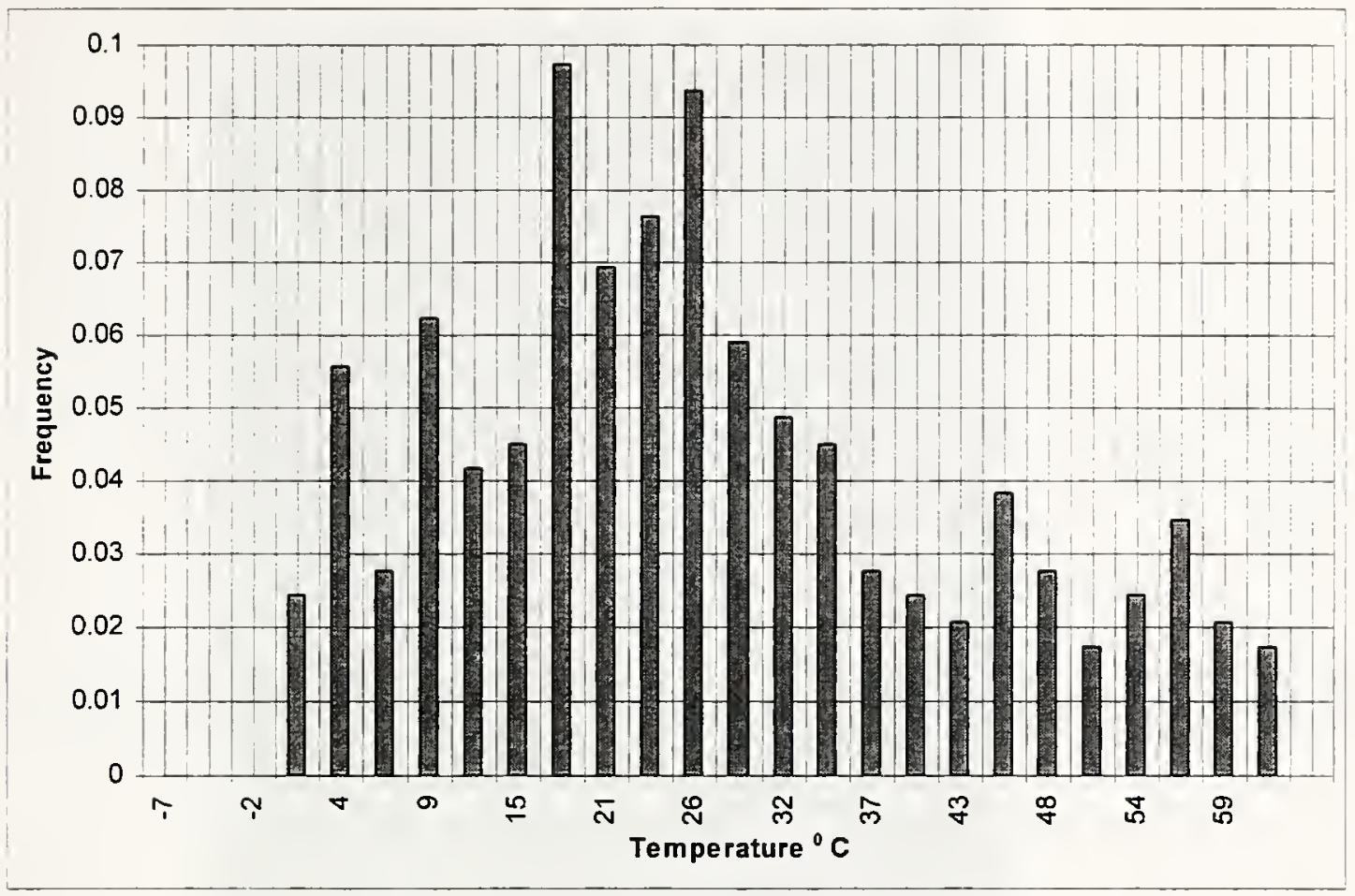

Figure 5.14 Highest Hourly Pavement Surface Temperature for Indiana (1993) 


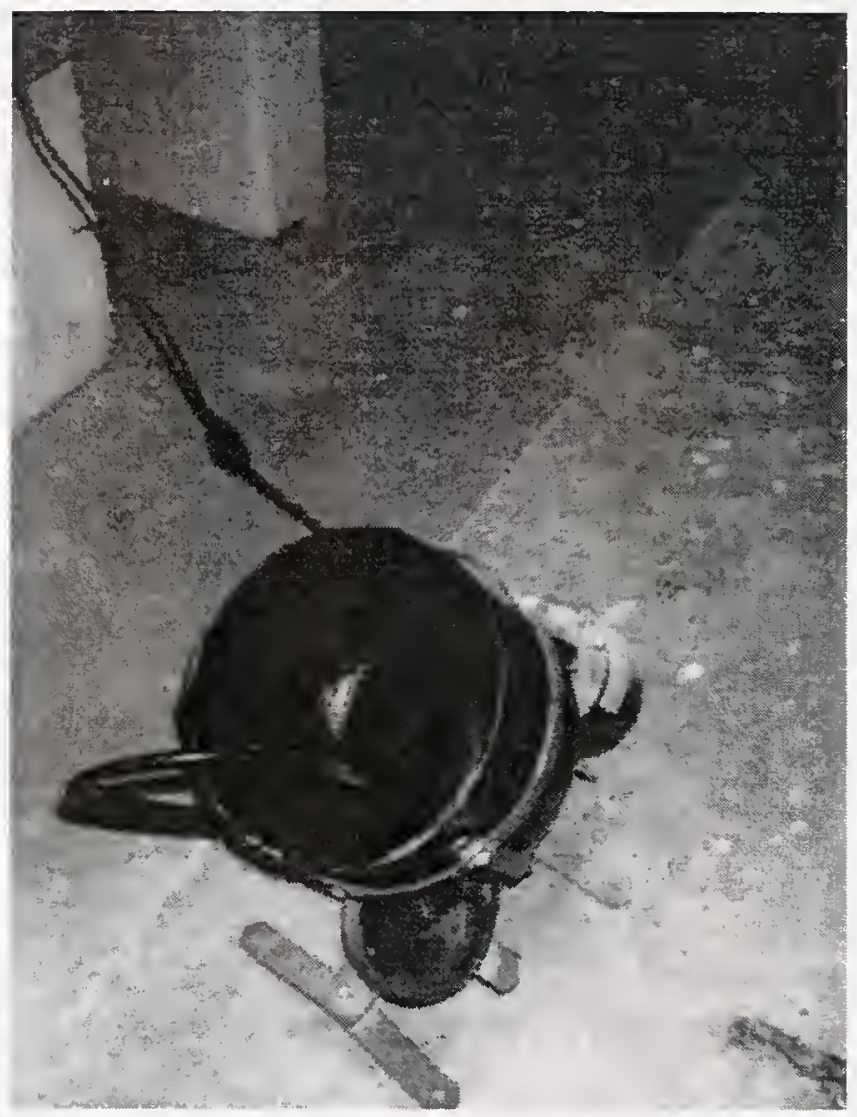

Figure 5.15 Mechanical Drum Mixer 
112

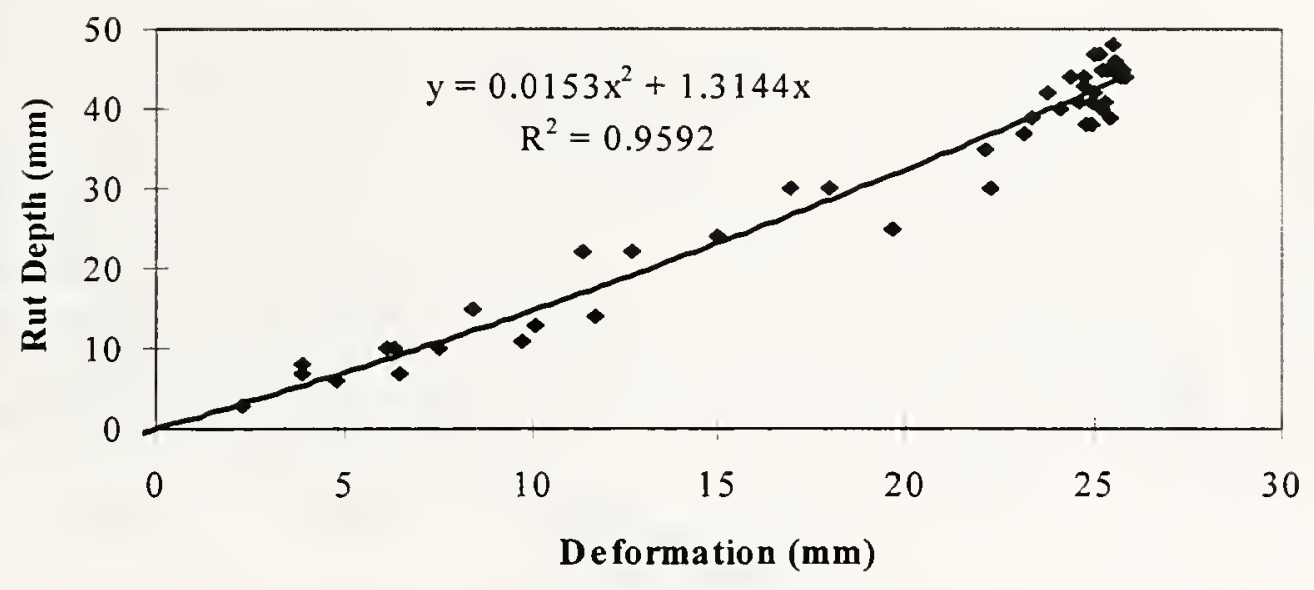

Figure 5.16 Relationship Between PURWheel Deformation and Measured Rut Depth 


\section{$11 \mathrm{DCM}$}

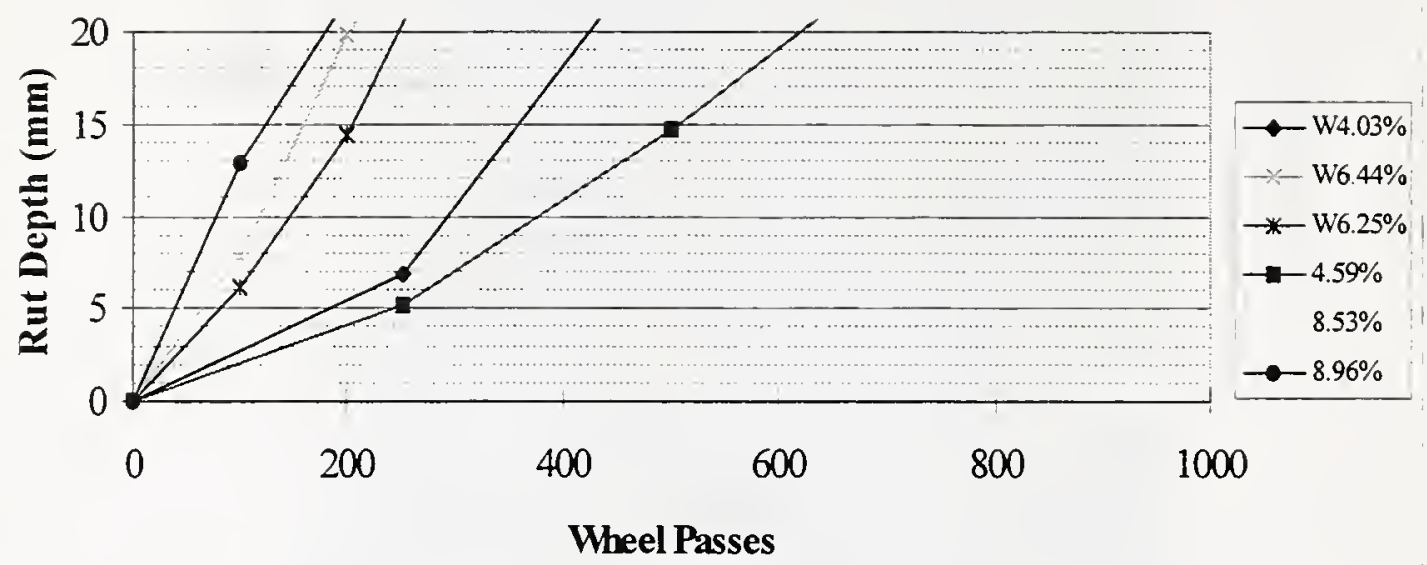

1. Legends represent \% air void contents of the samples

2. "W" represents wet test conditions (3 samples for either dry or wet conditions)

Figure 5.17 Wheel Track Test Results of Dolomite Surface Mixture, Control

\section{DBM}

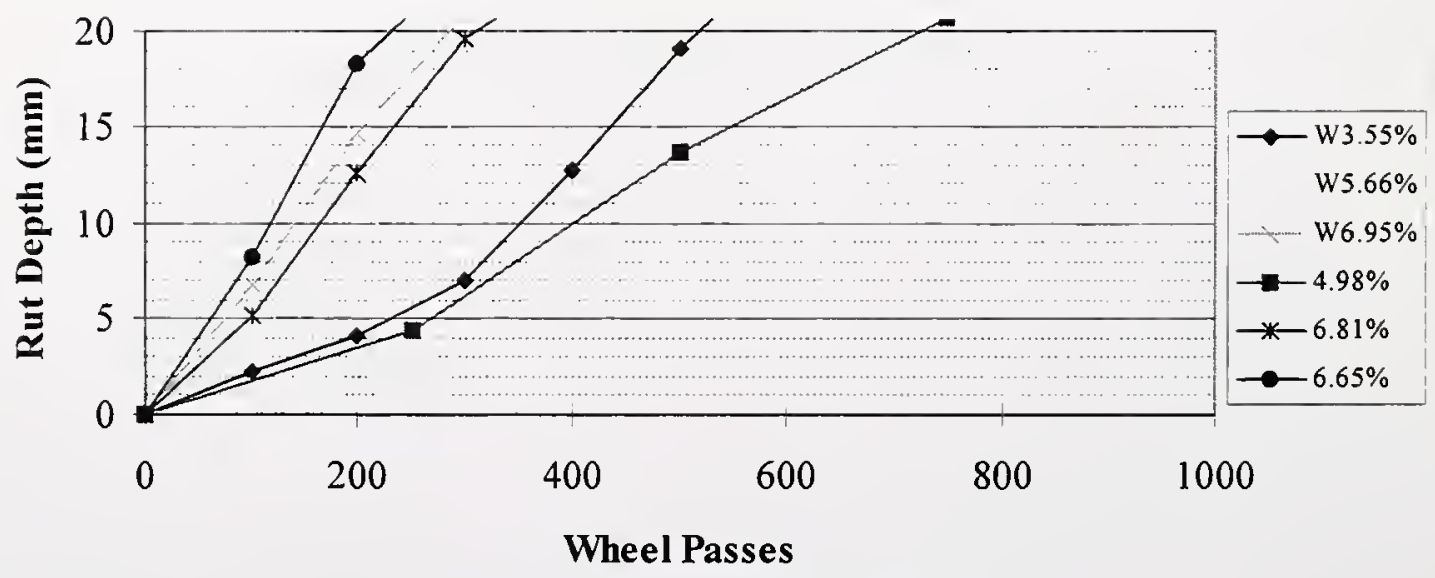

1. Legends represent $\%$ air void contents of the samples

2. "W" represents wet test conditions ( 3 samples for either dry or wet conditions)

Figure 5.18 Wheel Track Test Results of Dolomite Surface Mixture, Liquid Additive 


\section{DLM}

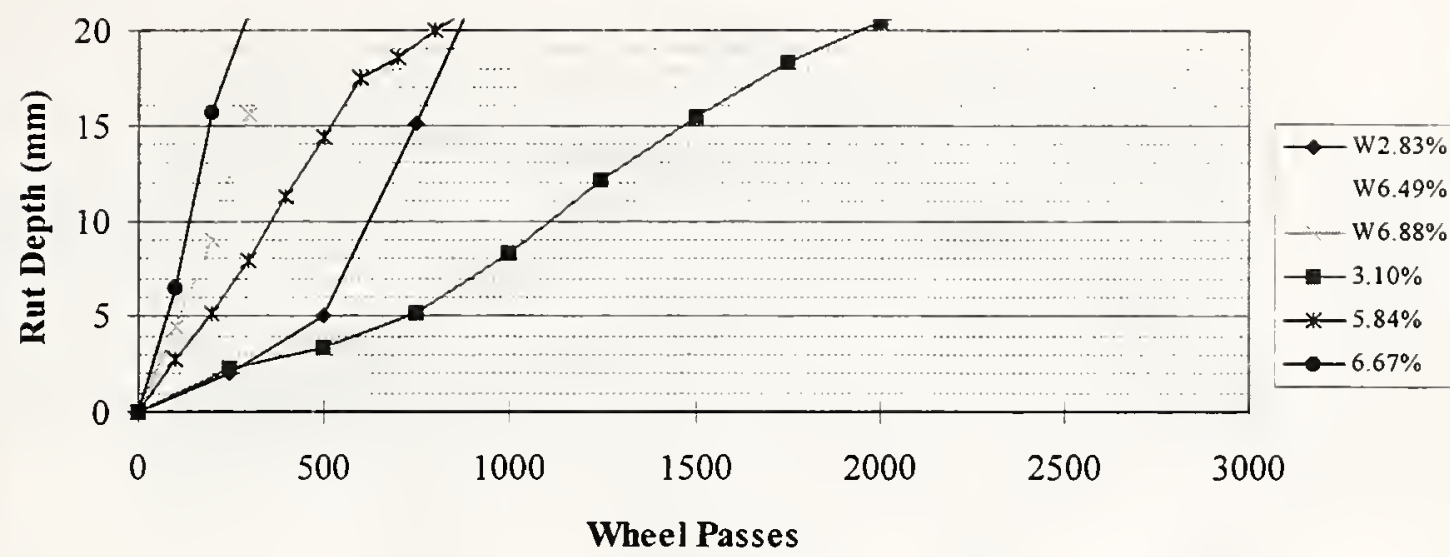

1. Legends represent \% air void contents of the samples

2. "W" represents wet test conditions ( 3 samples for either dry or wet conditions)

Figure 5.19 Wheel Track Test Results of Dolomite Surface Mixture, Hydrated Lime

\section{LCM}

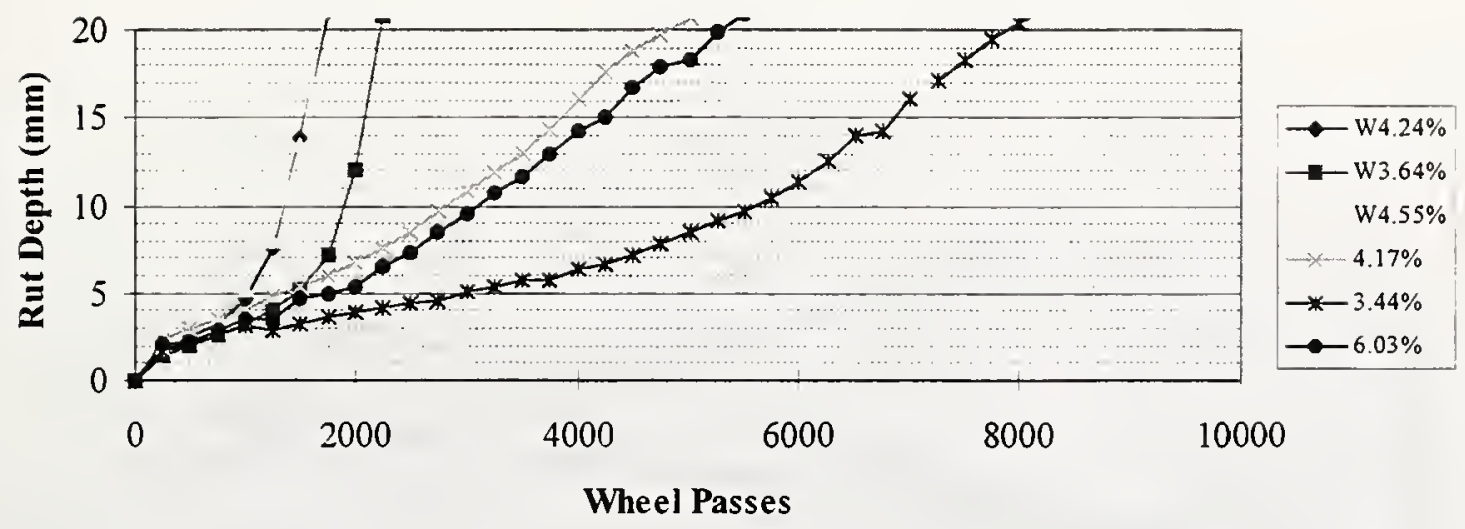

1. Legends represent $\%$ air void contents of the samples

2. "W" represents wet test conditions ( 3 samples for either dry or wet conditions)

Figure 5.20 Wheel Track Test Results of Limestone Surface Mixture, Control 
$11 \mathrm{SCM}$

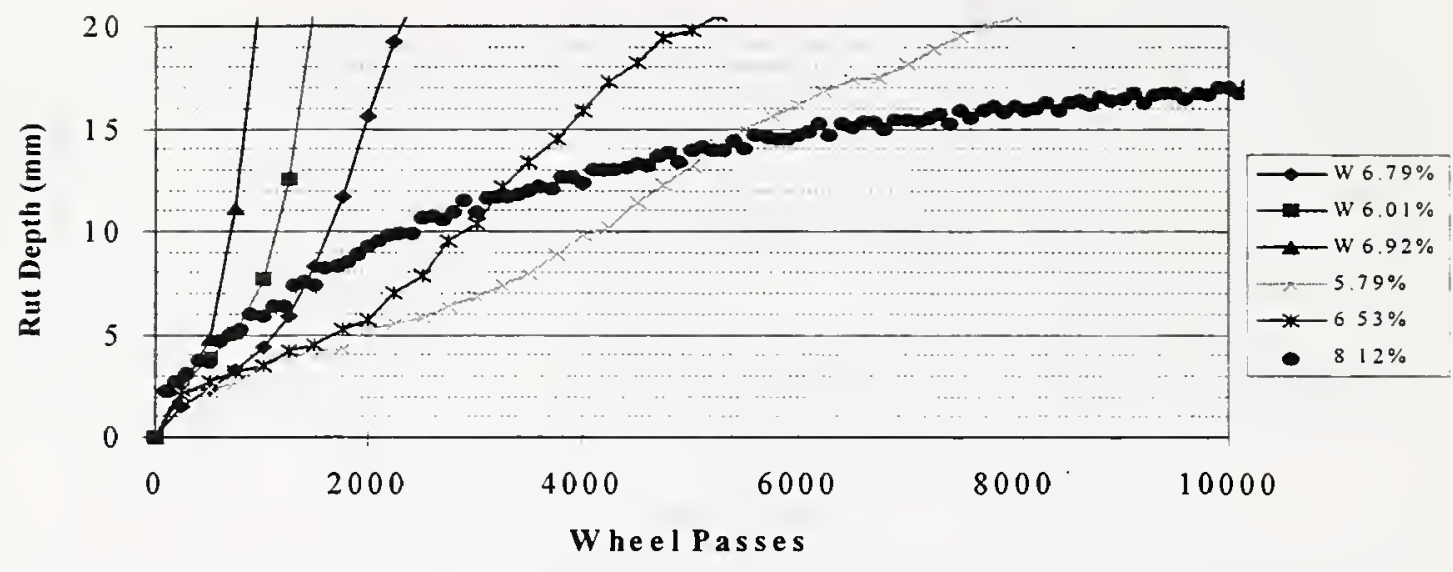

1. Legends represent \% air void contents of the samples

2. "W" represents wet test conditions( 3 samples for either dry or wet conditions)

Figure 5.21 Wheel Track Test Results of Slag Surface Mixture, Control

\#8 GCM

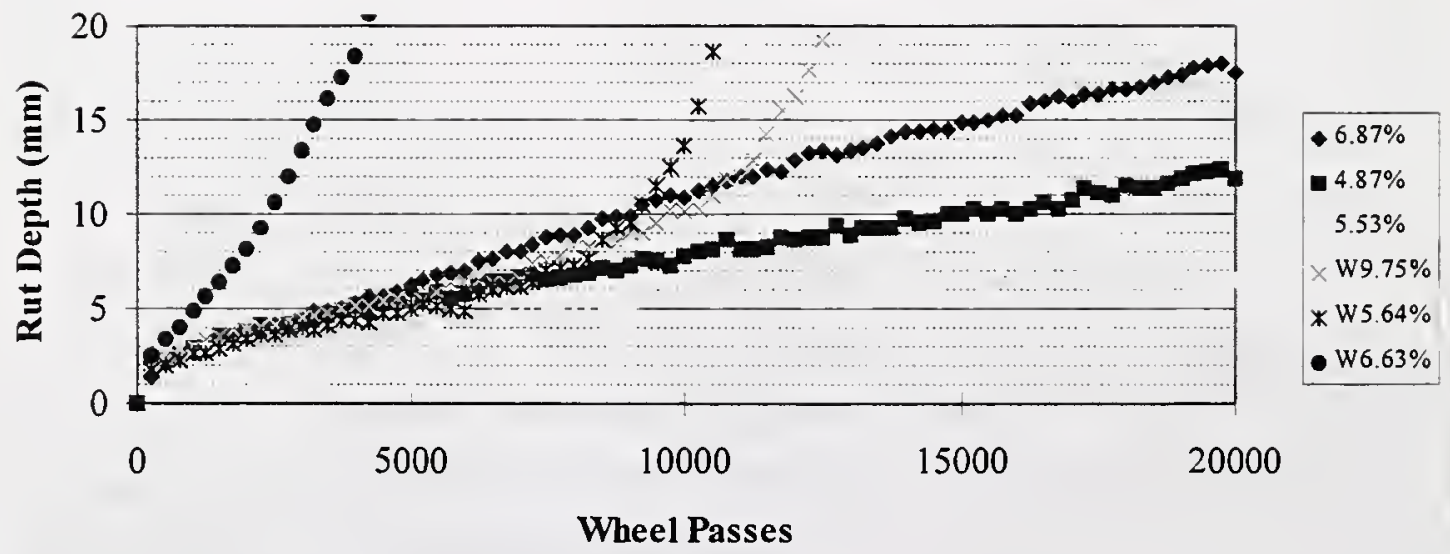

1. Legends represent $\%$ air void contents of the samples

2. "W" represents wet test conditions ( 3 samples for either dry or wet conditions)

Figure 5.22 Wheel Track Test Results of Gravel Binder Mixture, Control 


\section{\#8 GBM}

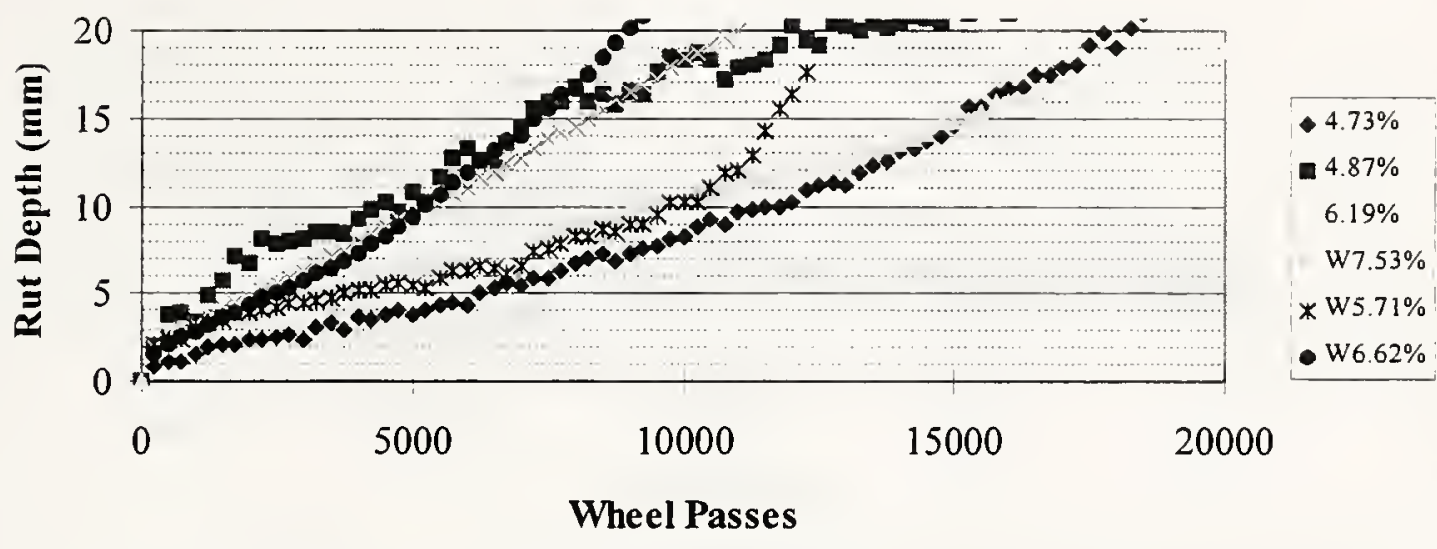

1. Legends represent $\%$ air void contents of the samples

2. "W" represents wet test conditions ( 3 samples for either dry or wet conditions)

Figure 5.23 Wheel Track Test Results of Gravel Binder Mixture, Liquid Additives

\section{\#8GLM}

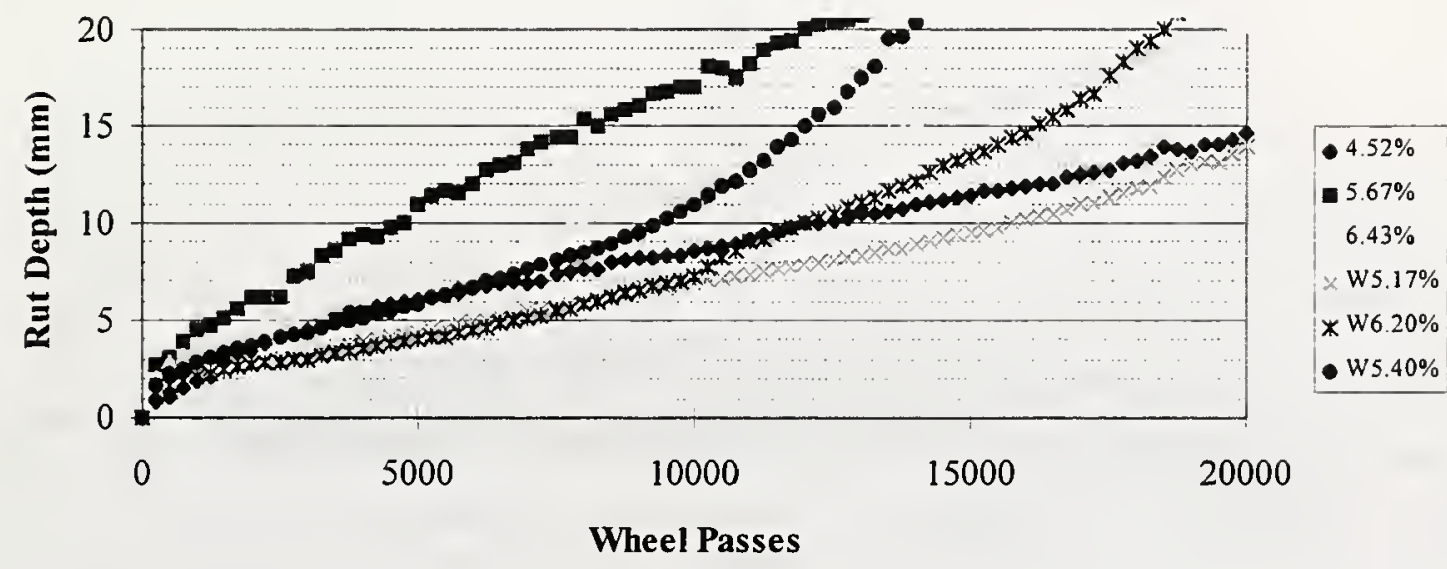

1. Legends represent $\%$ air void contents of the samples

2. "W" represents wet test conditions ( 3 samples for either dry or wet conditions)

Figure 5.24 Wheel Track Test Results of Gravel Binder Mixture, Hydrated Lime 
\#8 LCM

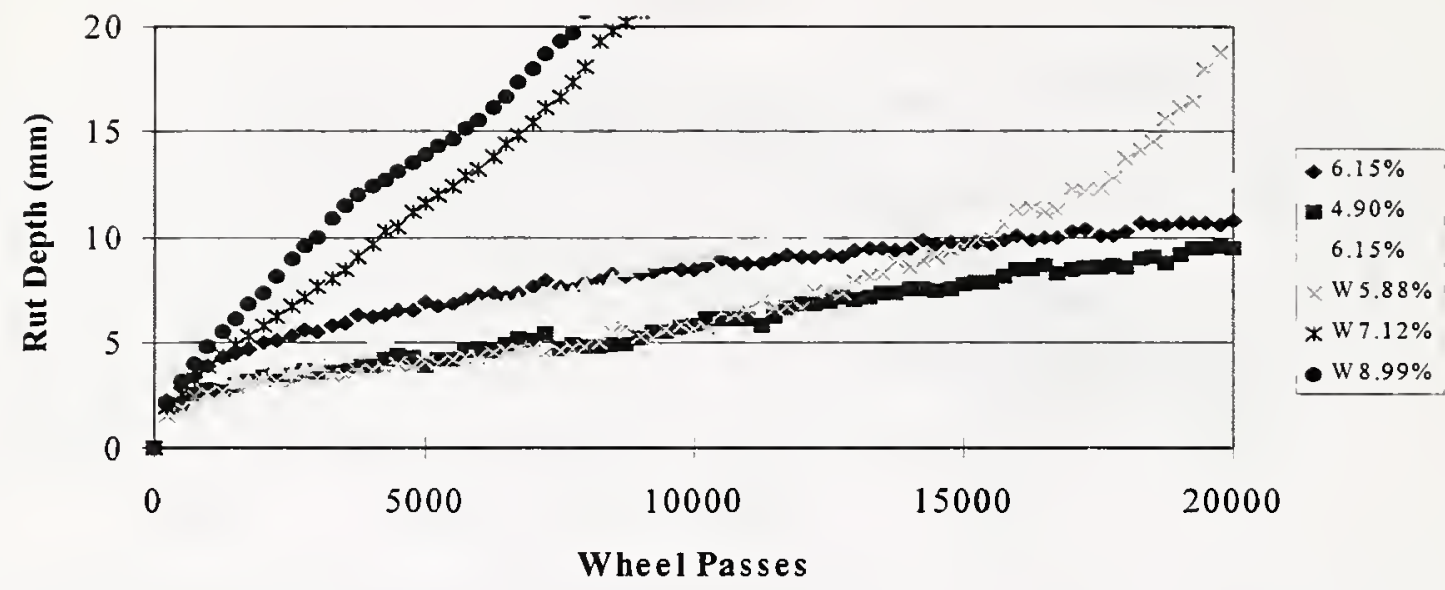

1. Legends represent $\%$ air void contents of the samples

2. "W" represents wet test conditions ( 3 samples for either dry or wet conditions)

Figure 5.25 Wheel Track Test Results of Limestone Binder Mixture, Control

\#8 SCM

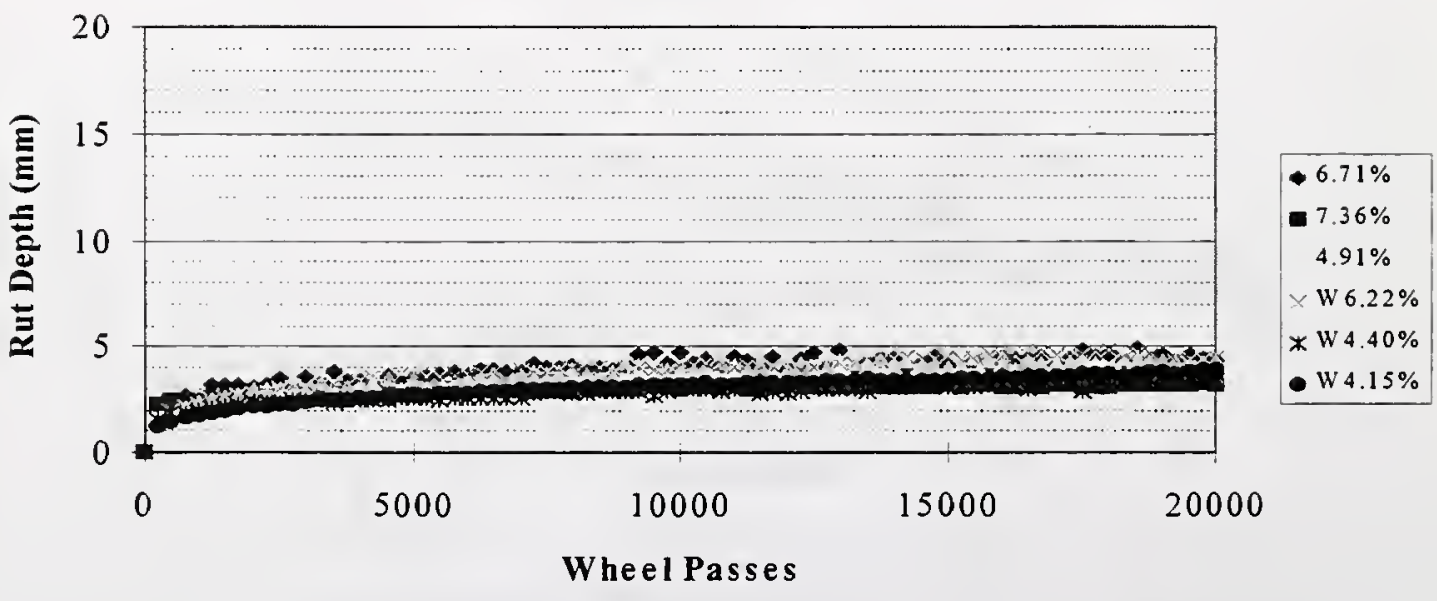

1. Legends represent $\%$ air void contents of the samples

2. "W" represents wet test conditions ( 3 samples for either dry or wet conditions)

Figure 5.26 Wheel Track Test Results of Slag Binder Mixture, Control 


\section{LCM}

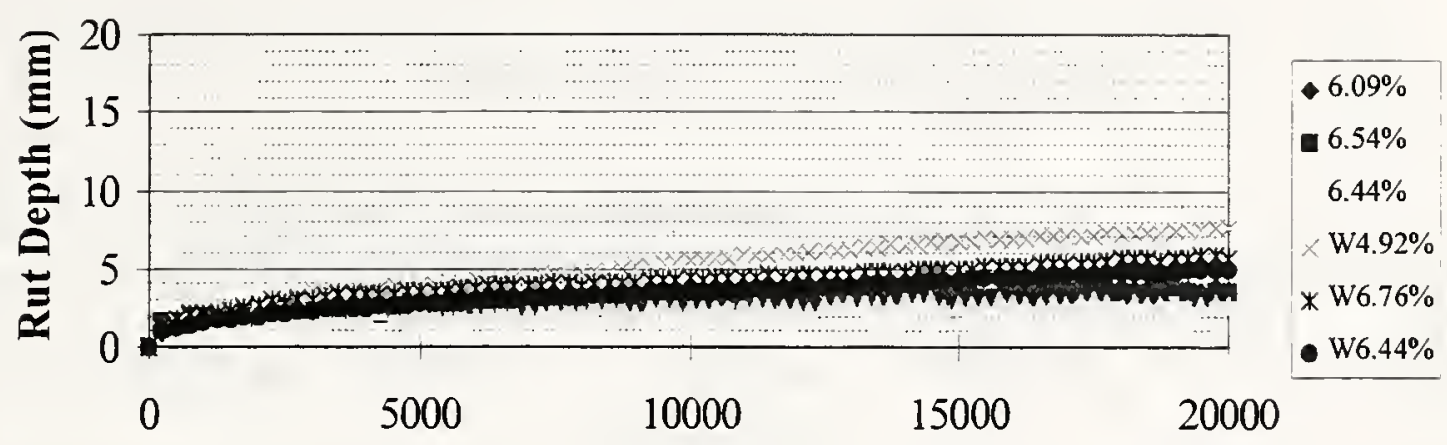

Wheel Passes

1. Legends represent \% air void contents of the samples

2. "W" represents wet test conditions ( 3 samples for either dry or wet conditions)

Figure 5.27 Wheel Track Test Results of Limestone Base Mixture, Control

\section{LBM}

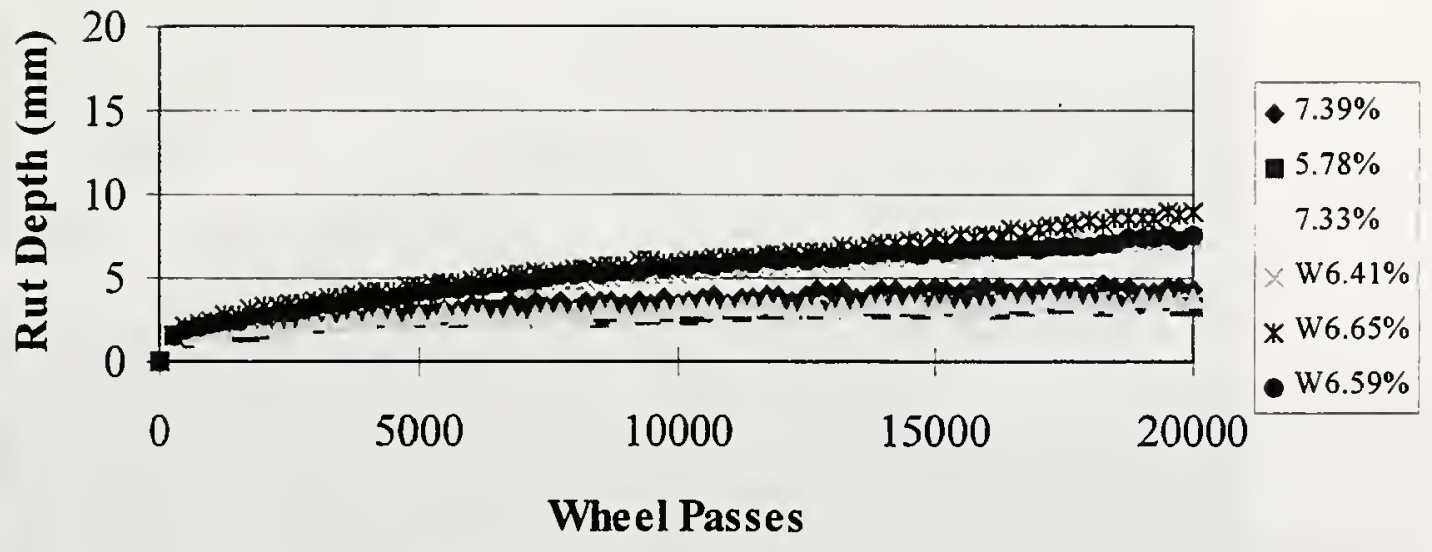

1. Legends represent \% air void contents of the samples

2. "W" represents wet test conditions (3 samples for either dry or wet conditions)

Figure 5.28 Wheel Track Test Results of Limestone Base Mixture, Liquid Additives 


\section{LLM}

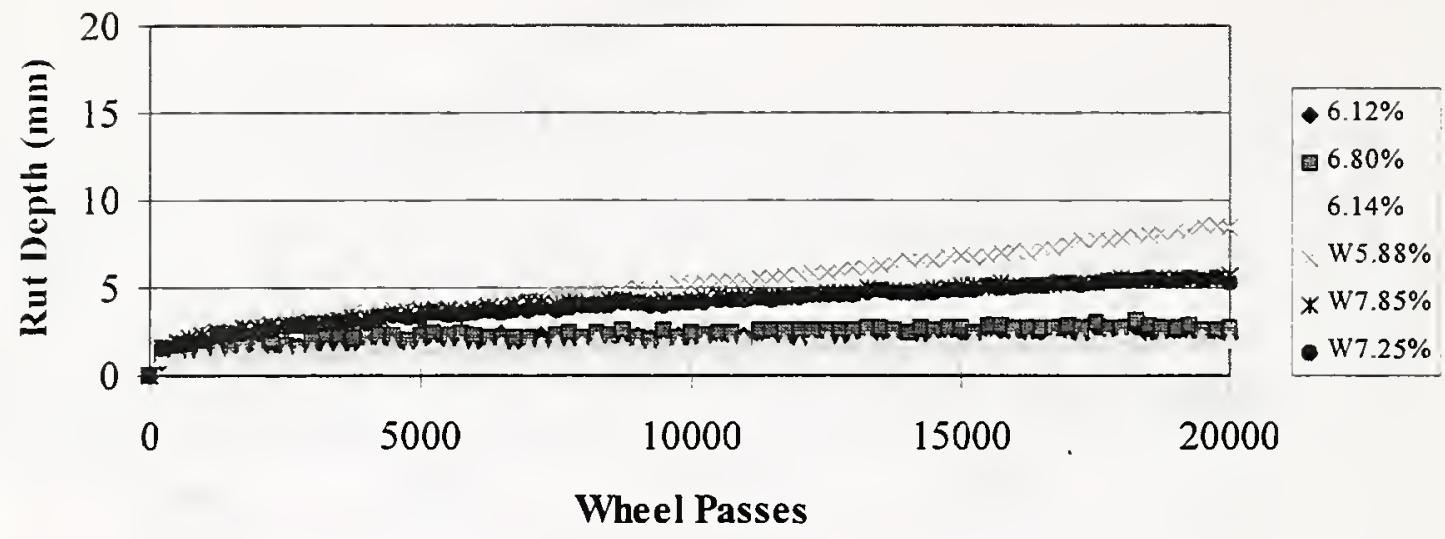

1. Legends represent $\%$ air void contents of the samples

2. "W" represents wet test conditions ( 3 samples for either dry or wet conditions)

Figure 5.29 Wheel Track Test Results of Limestone Base Mixture, Hydrated Lime

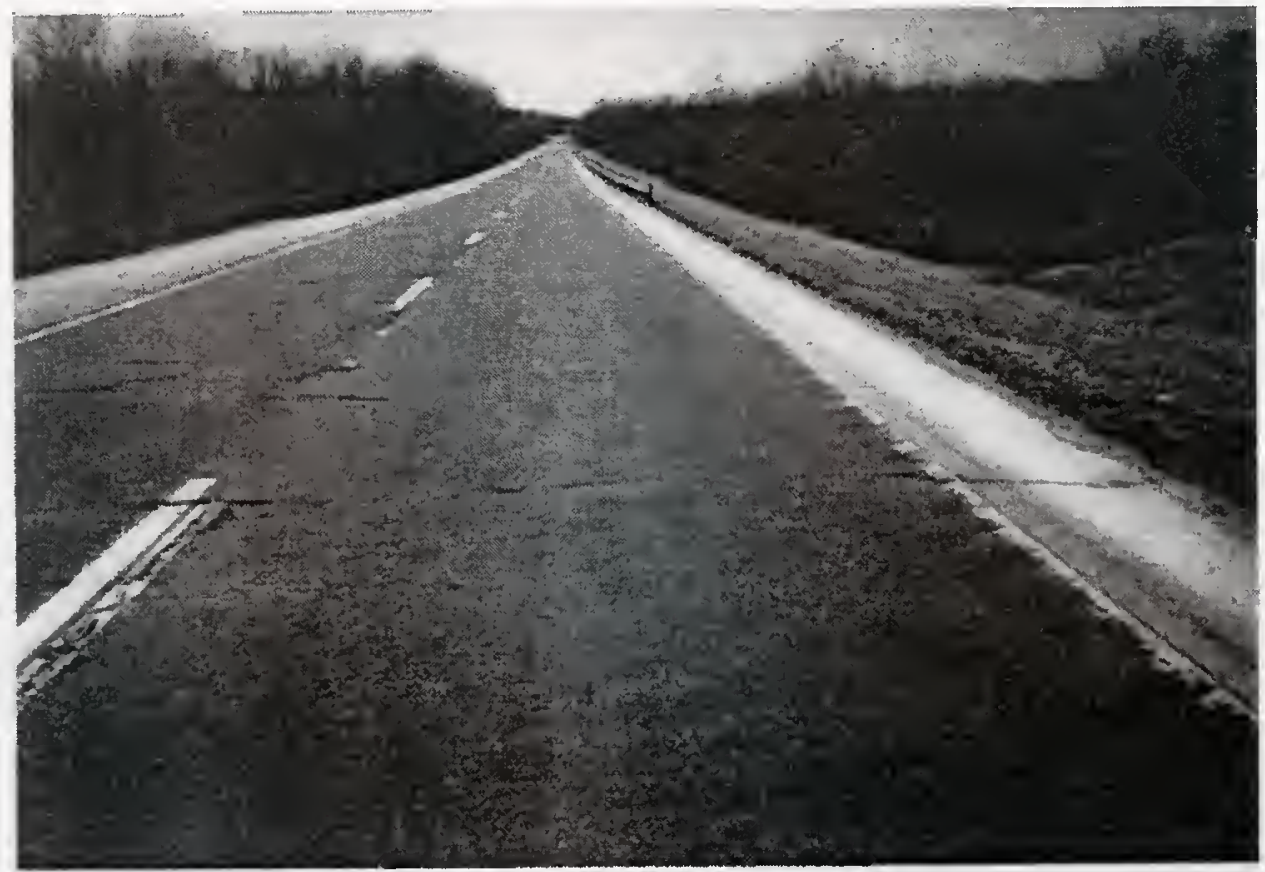

Figure 5.30 Typical Rutting and Corrugation Distress on I-64 


\section{CHAPTER 6 INFLUENCE OF TESTING TEMPERATURE AND MOISTURE ON PURWHEEL RESULTS}

Permanent deformation is an important factor in flexible pavement performance. According to Huang (1996), most of the permanent deformation occurs in the upper layers due to the increase in traffic loads and tire pressure. The current research involved developing a technology for predicting and evaluating permanent deformation using a laboratory wheel tracking device (PURWheel). The development is based on conducting a laboratory wheel track tests to define key mix parameters related to deformation. Laboratory wheel track tests were conducted wet and dry and at different temperature. A finite element method (FEM) analysis was conducted to model permanent deformation occurred in the PURWheel tests.

\subsection{Wheel Track Testing Results and Analysis}

\subsubsection{Temperature and Moisture Effects}

Results from laboratory wheel tests are shown in Figure 6.1 to Figure 6.10. The summary of deformation rates is shown in Table 6.1. It is obvious that damage occurs much faster with wet conditions and temperature is an important factor in identifying rutting potential. For both \#11 limestone and dolomite mixes, the number of wheel 
passes required to reach a $12.7 \mathrm{~mm}(1 / 2 \mathrm{in}$.) rut increases as the testing temperature decreases. At $60^{\circ} \mathrm{C}$, both mixes deformed rapidly without a creep deformation stage. This shows that the mix has already lost its integrity and can not resist the $620 \mathrm{kPa}$ tire loading. At $50^{\circ} \mathrm{C}$, the limestone mix is more stable than the dolomite mix.

Asphalt cement consistency is sensitive to the change of temperature. As a consequence, asphalt mixture stiffness is reduced at high ambient temperatures Mixture temperature susceptibility is depicted in Figure 6.11 and Figure 6.12. These figures indicated that there is a semi-log relationship between number of wheel passes required to reach a $12.7 \mathrm{~mm}$ rut and temperature. The rate of deformation at $40^{\circ} \mathrm{C}$ is ten times greater than that at $25^{\circ} \mathrm{C}$.

\subsubsection{Analysis for the Effect of Temperature and Moisture}

Moisture condition is of importance in the evaluation process for asphalt concrete rutting/stripping potential. From Figure 6.11 and Figure 6.12, the performancetemperature relationship for the dry and wet conditions are represented by two essentially parallel curves through the test temperature range. These results indicate that additional rutting damage results from moisture over the temperature range of $25^{\circ} \mathrm{C}$ to $60^{\circ} \mathrm{C}$. This maybe due to the hydraulic scouring mechanism and excessive pore pressure caused by the moving wheel loading. Additive rutting damage caused by moisture can be determined by subtracting it from the dry rutting damage. From Table 6.1, the Wet/Dry ratio of the deformation rates for both limestone and dolomite mixes are equal to 0.58 at 
$60^{\circ} \mathrm{C}$. This means that both mixes experienced the same relative moisture damage in the wheel track test. From Figure 4.10, the same conclusions can be drawn for AASHTO T283 test results, since the tensile strength ratio (TSR) for both mixtures is the same (TSR $=68 \%)$ and both AASHTO T-283 and PURWheel tests have the same conditioning temperatures at $60^{\circ} \mathrm{C}$.

A regression analysis was performed to relate the effects of moisture and temperature to rutting. Moisture condition was used as a class variable. The form of this model for both the \#11 limestone and \#11 dolomite mixtures was as follows:

$\log _{10}($ WHEEP $)=A+B^{*}$ TEMP $+C^{*}$ MOISTURE $+D^{*}$ TEMP*MOISTURE where:

$$
\begin{array}{ll}
\text { WHEEP } & =\text { Number of wheel passes at a } 12.7 \mathrm{~mm} \text { rut, } \\
\text { TEMP } & =\text { Test temperature, }{ }^{\circ} \mathrm{C}, \\
\text { MOISTURE } & =\text { Moisture conditions (dry and wet), and } \\
\text { A, B, C, D, } & =\text { Regression constants. }
\end{array}
$$

Table 6.2 to Table 6.4 summarizes the model statistics for the \#11 limestone and \#11 dolomite mixtures. Overall, the temperature effect was significant for both mixtures at the 99 percent level. The moisture condition was statistically significant for the limestone and dolomite mixes at the 90 and 99 percent levels, respectively. The interaction term was not significant for either mix. This implies that additional rutting damage results from moisture over the test temperature range $\left(25^{\circ} \mathrm{C}\right.$ to $\left.60^{\circ} \mathrm{C}\right)$. 


\subsection{Finite Element Modeling for the Wheel Tracking Test}

The finite element method (FEM) of analysis includes a geometric model, material model, boundary conditions, and a load model. The finite element method of analysis is a tool for numerical modeling that can be applied to many engineering problems, such as structural mechanics, heat transfer, ground water seepage, and many other areas.

In this study, the FEM software ABAQUS (ABAQUS, 1995) was selected to analyze the rutting behavior of asphalt mixtures. ABAQUS is a commercial finite element program. This program has been used previously to analyze flexible pavements and showed excellent agreement between FEM predicted pavement response and measured pavement response (Zaghloul, 1993). Also, the software has been utilized to model asphalt pavement rutting in accelerated pavement tests (Huang, 1996).

\subsubsection{Model Geometry}

In the study of PURWheel tests, a three dimensional finite element mesh was generated to represent a test slab of asphalt mixture. The cross section dimensions of PURWheel test slab is shown in Figure 6.13. This model consists of a $38 \mathrm{~mm}$ thick slab that is $305 \mathrm{~mm}$ wide and $305 \mathrm{~mm}$ long. The maximum size specimen that can be tested in the PURWheel is $622 \mathrm{~mm}$ long by $305 \mathrm{~mm}$ wide by $102 \mathrm{~mm}$ thick. 


\subsubsection{Boundary Conditions}

Boundary conditions for the finite element model can be considered in two parts. First, the contact between the bottom of slab and the steel box surface was modeled as a contact pair. As a result, nodes on the bottom of the slab are able to slide along the interface. Second, plaster of paris is used as a grout around the slab perimeter. Therefore, the end and side interface was modeled as a bonded contact. For this condition the nodes are constrained, being unable to separate from or slide along the vertical surface.

\subsubsection{Element Types}

In this analysis, the asphalt concrete slab was modeled using the eight-nodded three-dimensional stress/displacement elements. Finer meshing was generated in regions of high stress gradient. The three dimensional mesh used in the analysis is shown in Figure 6.14.

\subsubsection{Loading Models}

The PURWheel tests in this research utilized a pneumatic wheel. A $175 \mathrm{~kg}$ load was applied on the wheel at a tire pressure of $793 \mathrm{kPa}$. The gross contact area was 27.5 $\mathrm{cm}^{2}$. This results in a gross contact pressure of $620 \mathrm{kPa}$. An actual tire print is shown in 
Figure 6.15. In the FEM the contact area was modeled as a rectangular area $6.35 \mathrm{~cm}$ long and $4.32 \mathrm{~cm}$ wide.

Initially, a step load function was used in the analysis to simulated the moving wheel load in PURWheel. The duration of the step load function was 0.0728 second which corresponds to a speed of $33 \mathrm{~cm} / \mathrm{sec}$. Figure 6.16 shows the step load function used in the analysis. The length of time from $T_{0}$ to $T_{1}$ is a function of wheel speed and the length of the contact area between the loading wheel and the slab. The step load function was applied at the first set of elements and moved longitudinally to the next set of elements in the wheel path. When the loading step is applied to the last set of the elements, a single wheel pass was complete. The loading step was then reversed starting from the last set of elements and moved toward the first set of elements. A loading cycle was then complete. The load cycle was repeated for the desired repetitions.

This loading sequence simulated the cyclic moving wheel loads in the PURWheel. However, due to significant computer memory and running time requirement, an alternate load cycle was adopted. The alternate load cycle consisted of using a single step load function to approximate the wheel loading (Huang, 1996). The total loading time of the single step was 364 seconds which is equal to the cumulative loading time for 5000 wheel passes at $33 \mathrm{~cm} / \mathrm{sec}$. This approximation reduced the computation time from an estimated 40 hours to a reasonable amount of time ( 2 to 4 hours). . Figure 6.17 shows a 3-D view of deformed slab cross section modeled by FEM. 


\subsubsection{Material Properties}

Asphalt pavement deformation which occurs as a result of repeated loading is dependent both on the temperature and the period of time for which the load is applied (Croney and Croney, 1992). In order to simulate pavement permanent deformation, a creep model was used to characterize the material properties of the asphalt mixtures (Huang, 1996). The creep rate model in ABAQUS is:

$$
\dot{\varepsilon}=A \sigma^{n} t^{m}
$$

Where:

$$
\begin{array}{ll}
\dot{\mathcal{E}} & =\text { creep strain rate } \\
\sigma \quad & =\text { the uniaxial equivalent deviatoric stress } \\
t \quad & =\text { the total time } \\
A, m, n & =\text { parameters related to material properties }
\end{array}
$$

According to Huang (1996), the parameter $A$ changes the intercept of the creep curve without changing the slope of the creep curve on a log-log scale. As a result, the parameter $A$ in the current analysis was backcalculated by matching the intercept of measured deformation curves. Parameter $n$ is associated with the contact pressure. Huang (1996) selected a value of $n$ of 0.8 for tests with a $620 \mathrm{kPa}$ contact pressure. Since the current analysis was also conducted with a contact pressure of $620 \mathrm{kPa}$, the same value of $n$ was selected. The parameter $m$ in the creep model defines the slope of the 
creep curves on a log-log scale. This parameter is important and is the primary parameter utilized to study mixture rutting potential.

\subsubsection{Model Verification}

A backcalculation technology was used to obtain the creep model parameters, $A$ and $m$ (Huang and White, 1996). Parameter $m$ was estimated first to match the slope of PURWheel deformation curves. After the parameter $m$ was determined, the $A$ value was estimated by matching the deformation curves occurring during the post compaction stage which is described in Chapter Five.

The verification study was conducted by using test results of both the PURWheel and the Accelerated Pavement Tester (APT) results on the same $\# 8$ gravel binder mixture. Both APT and PURWheel tests were conducted using the same contact pressure (620 $\mathrm{kPa})$ and the same temperature $\left(38^{\circ} \mathrm{C}\right)$. Parameters for the creep model were obtained based on PURWheel test results. These parameter values and material properties used in the analysis were as follows:

$$
\begin{array}{ll}
\text { Modulus of Elasticity } & =3.1 \times 10^{6} \mathrm{kPa}(450,000 \mathrm{psi}) \\
\text { Poisson's Ratio } & =0.3 \\
\text { Creep Model Parameter } A & =2.60 \times 10^{-4} \\
n & =0.8 \\
m & =-0.52
\end{array}
$$


Figure 6.18 shows the fitted curves and deformation data from the PURWheel tests. Once the parameters for the creep model have been obtained, those parameters can be utilized in the APT finite element analysis (Huang, 1996). Figure 6.19 shows the results of predicted deformation curves for the APT tests based on backcalculated creep rate model parameters and material properties from PURWheel tests.

\subsubsection{Effect of Temperature}

Two mixtures, \#11 limestone and \#11 dolomite surface mixes, were select for backcalculation of material parameters in the creep model. Table 6.5 lists the backcalculated material parameters for the two mixtures at each temperature. Figure 6.20 through Figure 6.29 show the fitted curve and deformation data from the PURWheel tests.

Figure 6.30 shows the effects of temperature on parameter $m$. Parameter $m$ is smaller (more negative) at lower temperature than at higher temperature. The limestone mix has better rut resistance than the dolomite mix at high temperature $\left(50\right.$ and $\left.60^{\circ} \mathrm{C}\right)$. At $50^{\circ} \mathrm{C}$ and higher temperatures the asphalt cement has low stiffness and the aggregate structure provides the majority of the rutting resistance.

Regression analyses were conducted to correlated the parameter $m$ with the rutting susceptibilities of the mixtures at different test temperature. It is found that parameter $m$ is strongly related to the test temperature. Figure 6.30 shows the effects of temperature on parameter $m$ along with the linear regression equations. The coefficient of 
determination (adj. $\mathrm{R}^{2}$ ) for the equation is about 0.94 for the limestone and dolomite mixtures. It is clear that parameter $m$ increases (less negative) with increase of temperature, and the dolomite mix is more susceptible to rutting when temperature is higher than $50^{\circ} \mathrm{C}$.

Parameter $A$ for both mixtures is a constant at the different test temperature levels. this means that parameter $A$ does not appear to be influenced by the change of temperature. The dolomite mix has a greater value of parameter $A$ which means the dolomite mix experienced more deformation at the post compaction stage.

\subsection{Summary}

PURWheel tests show the abilities of the machine to evaluate the rutting/stripping potential of asphalt mixtures under various temperature/moisture conditions. In a comparison of two Indiana \#11 surface mixtures, limestone and dolomite, the limestone mix is shown to have a lower susceptibility to rutting than that of the dolomite mix at 50 and $60^{\circ} \mathrm{C}$. Moisture damage was shown to occur over a range of temperatures from $60^{\circ}$ $\mathrm{C}$ to the room temperature.

Results of model verification studies show that the creep model can successfully characterize the pavement material behavior through a reasonable approximation of loading and material properties. Based on deformation data from the PURWheel tests, material parameters in the creep model were backcalculated. Good agreement was 
obtained between FEM predicted deformation and that measured of the same mixture in APT tests.

In the analysis for a single tire pressure, parameter $n$ was fixed at 0.8 while material parameters $A$ and $m$ were backcalculated by matching the deformation caused by post-compaction and creep slope of measured deformation curves in the PURWheel tests.

The material parameter $m$ is strongly related to the temperature and aggregate type. Regression analyses show that parameter $m$ increases with increase of temperature and the dolomite mix is more susceptible to rutting at high temperature. 
Table 6.1 Wheel Track Test Results Summary (Wheel Passes@12.7 mm Rut)

\begin{tabular}{|c|c|c|c|c|c|}
\hline Types of Agg. & $\begin{array}{l}\text { Dry Test (Air } \\
\text { Voids, \%) }\end{array}$ & $\begin{array}{l}\text { Est. Passes @ } \\
6 \% \text { Air Voids }\end{array}$ & $\begin{array}{l}\text { Wet Test (Air } \\
\text { Voids, \%) }\end{array}$ & $\begin{array}{l}\text { Est. Passes @ } \\
6 \% \text { Air Voids }\end{array}$ & $\begin{array}{c}\text { Wet/Dry } \\
\text { Ratio }\end{array}$ \\
\hline \multirow{3}{*}{$\# 11$ Limestone $60^{\circ}$} & $2600(4.17)$ & \multirow{3}{*}{2532} & $1300(4.24)$ & \multirow{3}{*}{1477} & \multirow{3}{*}{0.58} \\
\hline & $5170(3.4)$ & & $1840(3.64)$ & & \\
\hline & $2850(6.03)$ & & $1290(4.55)$ & & \\
\hline \multirow{3}{*}{$\# 11$ Limestone $50^{\circ} \mathrm{C}$} & $11500(3.15)$ & \multirow{3}{*}{14733} & $6000(3.72)$ & \multirow{3}{*}{6373} & \multirow{3}{*}{0.43} \\
\hline & $12700(3.78)$ & & $7400(3.54)$ & & \\
\hline & $>20000(3.91)$ & & $5600(4.32)$ & & \\
\hline \multirow{3}{*}{$\# 11$ Limestone $40^{\circ} \mathrm{C}$} & $13500(5.02)$ & \multirow{3}{*}{16530} & $16300(3.54)$ & \multirow{3}{*}{8509} & \multirow{3}{*}{0.51} \\
\hline & $>20000(4.64)$ & & $17500(4.63)$ & & \\
\hline & $16750(6.85)$ & & $7250(5.90)$ & & \\
\hline \multirow{3}{*}{$\# 11$ Limestone $30^{\circ} \mathrm{C}$} & $40000(7.26)$ & \multirow{3}{*}{51596} & $30000(7.40)$ & \multirow{3}{*}{18000} & \multirow{3}{*}{0.35} \\
\hline & $25000(9.21)$ & & $18107(6.82)$ & & \\
\hline & $40000(7.60)$ & & $18393(6.24)$ & & \\
\hline \multirow{3}{*}{$\# 11$ Limestone $25^{\circ} \mathrm{C}$} & $270257(6.39)$ & \multirow{3}{*}{280799} & $142192(6.93)$ & \multirow{3}{*}{112939} & \multirow{3}{*}{0.40} \\
\hline & $409215(6.59)$ & & $76564(7.26)$ & & \\
\hline & $384910(7.18)$ & & $131965(7.91)$ & & \\
\hline \multirow{3}{*}{$\# 11$ Dolomite $60^{\circ}$} & $350(4.59)$ & \multirow{3}{*}{257} & $291(4.03)$ & \multirow{3}{*}{146} & \multirow{3}{*}{0.57} \\
\hline & $82(8.53)$ & & $108(6.44)$ & & \\
\hline & $70(8.96)$ & & $133(6.25)$ & & \\
\hline \multirow{3}{*}{$\# 11$ Dolomite $50^{\circ} \mathrm{C}$} & $1576(5.92)$ & \multirow{3}{*}{1278} & $780(4.99)$ & \multirow{3}{*}{598} & \multirow{3}{*}{0.47} \\
\hline & $200(9.25)$ & & $525(6.13)$ & & \\
\hline & $460(7.08)$ & & $566(6.43)$ & & \\
\hline \multirow{3}{*}{$\# 11$ Dolomite $40^{\circ} \mathrm{C}$} & $7750(5.68)$ & \multirow{3}{*}{9833} & $5600(4.57)$ & \multirow{3}{*}{5767} & \\
\hline & $12500(4.73)$ & & $5600(4.46)$ & & 0.59 \\
\hline & $9500(5.07)$ & & $6100(5.07)$ & & \\
\hline & $28000(6.74)$ & & $17864(6.29)$ & & \\
\hline \#11 Dolomite $30^{\circ} \mathrm{C}$ & $30000(6.74)$ & 37752 & $13337(6.08)$ & 18485 & 0.49 \\
\hline & $40000(5.81)$ & & $40000(4.53)$ & & \\
\hline & $132663(6.93)$ & & $40249(6.67)$ & & \\
\hline \#11 Dolomite $25^{\circ} \mathrm{C}$ & $155412(5.60)$ & 164311 & $84284(6.61)$ & 71310 & 0.43 \\
\hline & $195342(6.04)$ & & $75303(5.65)$ & & \\
\hline
\end{tabular}


Table 6.2 Statistical Values for Temperature/Moisture Regression Models

\begin{tabular}{|c|c|c|c|c|}
\hline Mixture & \multicolumn{1}{|c|}{ R-Square } & Adj. R-Sq. & Root MSE & Mean \\
\hline Limestone & 0.9022 & 0.8532 & 0.6221 & 9.7083 \\
\hline Dolomite & 0.9912 & 0.9868 & 0.2796 & 8.5481 \\
\hline \multicolumn{5}{|c|}{ Type I Tests } \\
\hline Mixture & $\begin{array}{l}\text { Full Model } \\
\text { F-value (Pr }>\text { F) }\end{array}$ & $\begin{array}{l}\text { TEMP } \\
\text { F-value (Pr }>\text { F) }\end{array}$ & $\begin{array}{l}\text { MOISTURE } \\
\text { F-value (Pr }>\text { F) }\end{array}$ & $\begin{array}{l}\text { TEMP*MOISTURE } \\
\text { F-value (Pr }>\text { F) }\end{array}$ \\
\hline Limestone & $18.44(0.0020)$ & $51.05(0.0004)$ & $4.14(0.0880)$ & $0.13(0.7321)$ \\
\hline Dolomite & $224.76(0.0001)$ & $659.29(0.0001)$ & $14.85(0.0084)$ & $0.14(0.7256)$ \\
\hline
\end{tabular}

Note: number of samples $=10$

TEMP: PURWheel test temperature

MOISTURE: dry or wet

Table 6.3 Parameter Estimates - \#11 Limestone Mix

\begin{tabular}{|c|c|c|c|c|c|}
\hline Variable & $\mathrm{df}$ & Estimate & Std. Error & T Stat. & Prob. $>|\mathrm{T}|$ \\
\hline INTERCEPT & 1 & 13.5821 & 0.9332 & 14.5549 & 0.0001 \\
\hline TEMP & 1 & -0.1043 & 0.0217 & -4.7987 & 0.0030 \\
\hline MOISTURE & 1 & 1.2529 & 1.3197 & 0.9494 & 0.3791 \\
\hline TEMP*MOISTURE & 1 & -0.0110 & 0.0307 & -0.3578 & 0.7321 \\
\hline
\end{tabular}

Note: number of samples $=10$

TEMP: PURWheel test temperature

MOISTURE: dry or wet 
Table 6.4 Parameter Estimates - \#11 Dolomite Mix

\begin{tabular}{|c|c|c|c|c|c|}
\hline Variable & $\mathrm{df}$ & Estimate & Std. Error & T Stat. & Prob. $>|\mathrm{T}|$ \\
\hline INTERCEPT & 1 & 15.3722 & 0.4194 & 36.6496 & 0.0001 \\
\hline TEMP & 1 & -0.1748 & 0.0098 & -17.8960 & 0.0001 \\
\hline MOISTURE & 1 & 0.8897 & 0.5932 & 1.4999 & 0.1843 \\
\hline TEMP*MOISTURE & 1 & -0.0051 & 0.0138 & -0.3678 & 0.7256 \\
\hline
\end{tabular}

Note: number of samples $=10$

TEMP: PUR Wheel test temperature

MOISTURE: dry or wet

Table 6.5 Backcalculated Material Parameters

\begin{tabular}{|c|c|c|c|c|}
\hline \multirow{2}{*}{$\begin{array}{l}\text { Types of } \\
\text { Aggregate }\end{array}$} & \multirow{2}{*}{$\begin{array}{c}\text { Test } \\
\text { Temperature, }{ }^{0} \mathrm{C}\end{array}$} & \multicolumn{3}{|c|}{ Model Parameter } \\
\hline & & $A \times 10^{-4}$ & $n$ & $m$ \\
\hline \multirow{5}{*}{ \#11 Limestone } & 60 & 2.0 & 0.8 & -0.34 \\
\hline & 50 & 2.0 & 0.8 & -0.59 \\
\hline & 40 & 2.0 & 0.8 & -0.65 \\
\hline & 30 & 2.0 & 0.8 & -0.78 \\
\hline & 25 & 2.0 & 0.8 & -0.89 \\
\hline \multirow{5}{*}{ \#11 Dolomite } & 60 & 2.6 & 0.8 & -0.11 \\
\hline & 50 & 2.6 & 0.8 & -0.23 \\
\hline & 40 & 2.6 & 0.8 & -0.65 \\
\hline & 30 & 2.6 & 0.8 & -0.78 \\
\hline & 25 & 2.6 & 0.8 & -0.89 \\
\hline
\end{tabular}




\section{DCM}

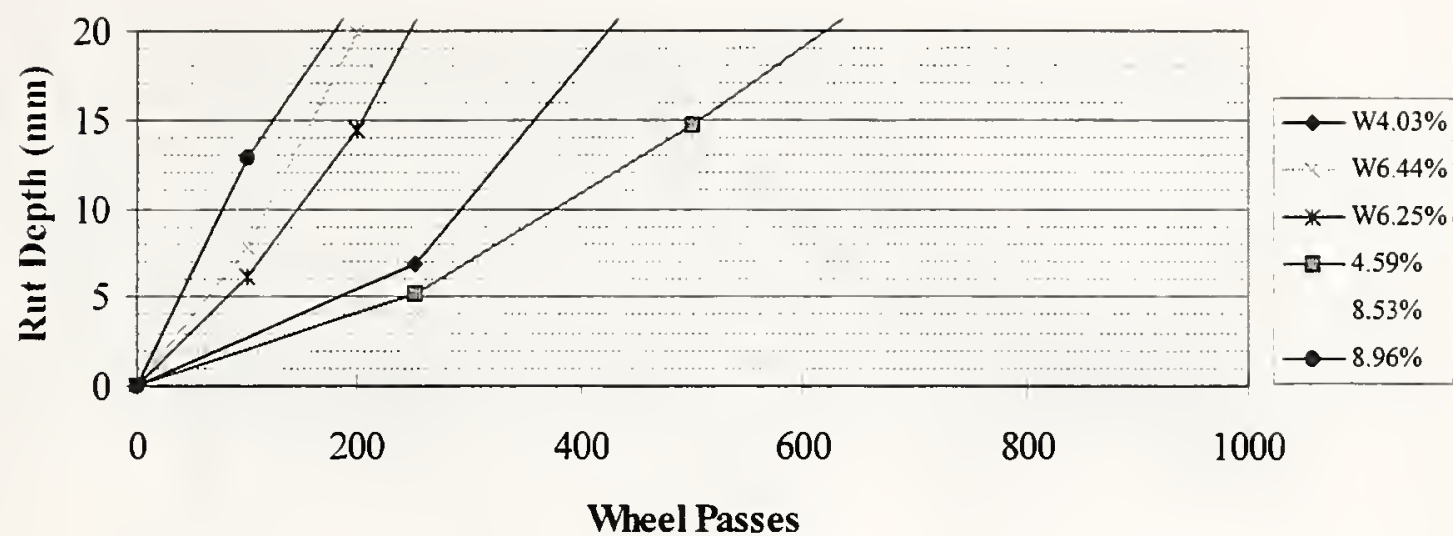

1. Legends represent \% air void contents of the samples

2. "W" represents wet test conditions

Figure 6.1 Wheel Track Test Results of Dolomite Surface Mixture, $60^{\circ} \mathrm{C}$

DCM 50 deg.

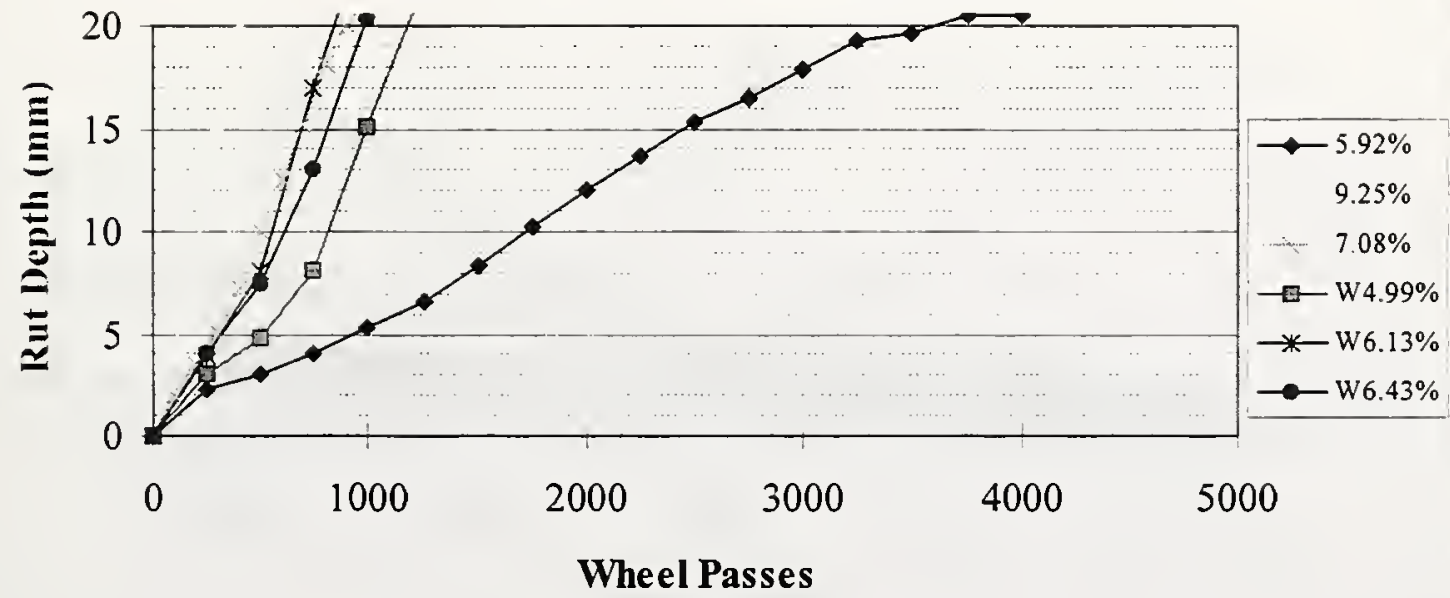

1. Legends represent $\%$ air void contents of the samples

2. "W" represents wet test conditions

Figure 6.2 Wheel Track Test Results of Dolomite Surface Mixture, $50^{\circ} \mathrm{C}$ 


\section{CM 40 deg.}

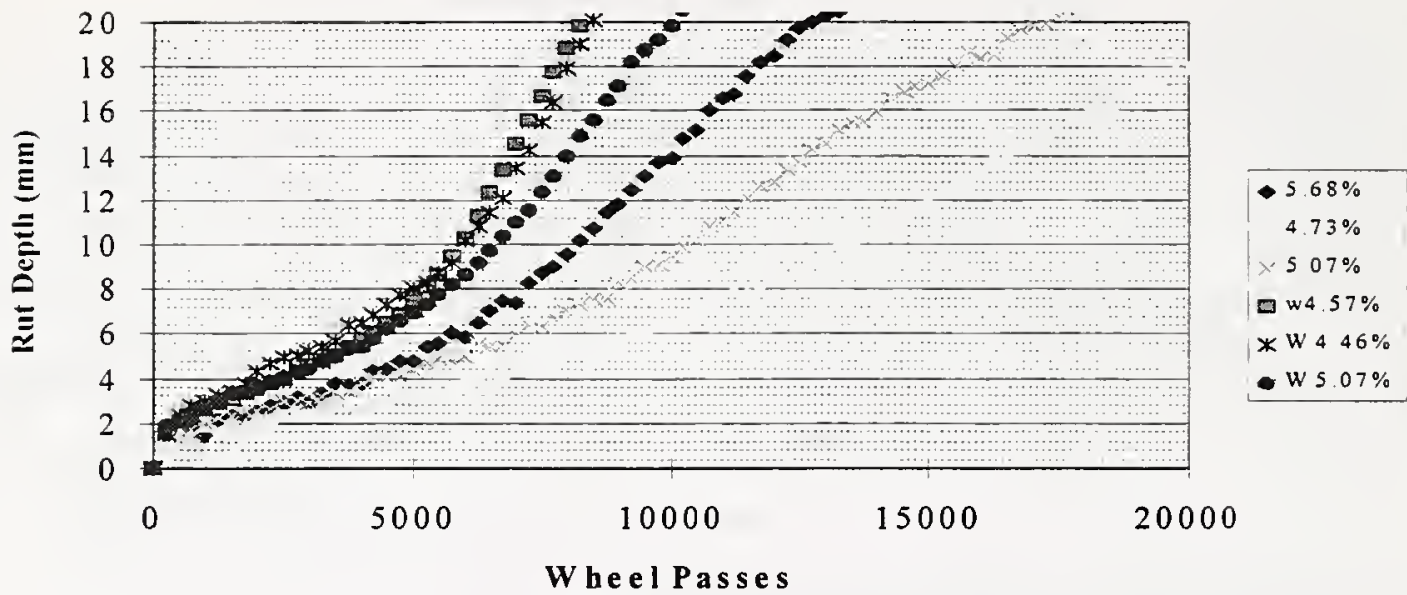

1. Legends represent \% air void contents of the samples

2. "W" represents wet test conditions

Figure 6.3 Wheel Track Test Results of Dolomite Surface Mixture, $40^{\circ} \mathrm{C}$

\section{\#11 Dolomite, 30 Deg.}

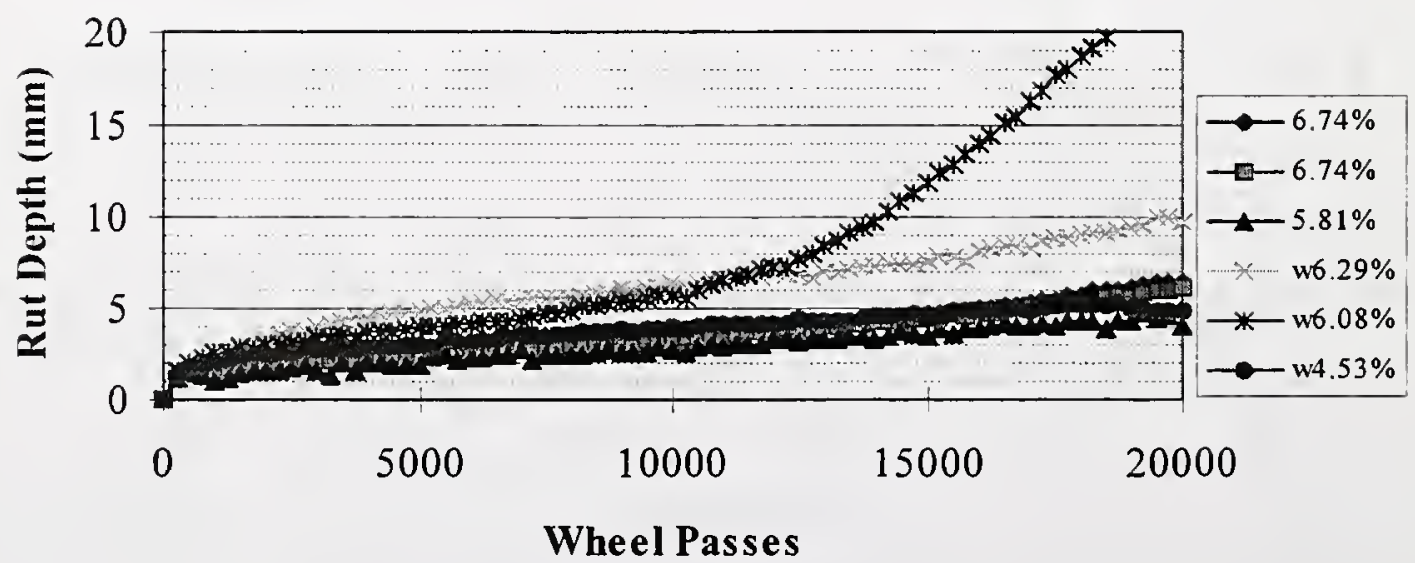

1. Legends represent $\%$ air void contents of the samples

2. "W" represents wet test conditions

Figure 6.4 Wheel Track Test Results of Dolomite Surface Mixture, $30^{\circ} \mathrm{C}$ 


\section{DCM, $25 \mathrm{C}$}

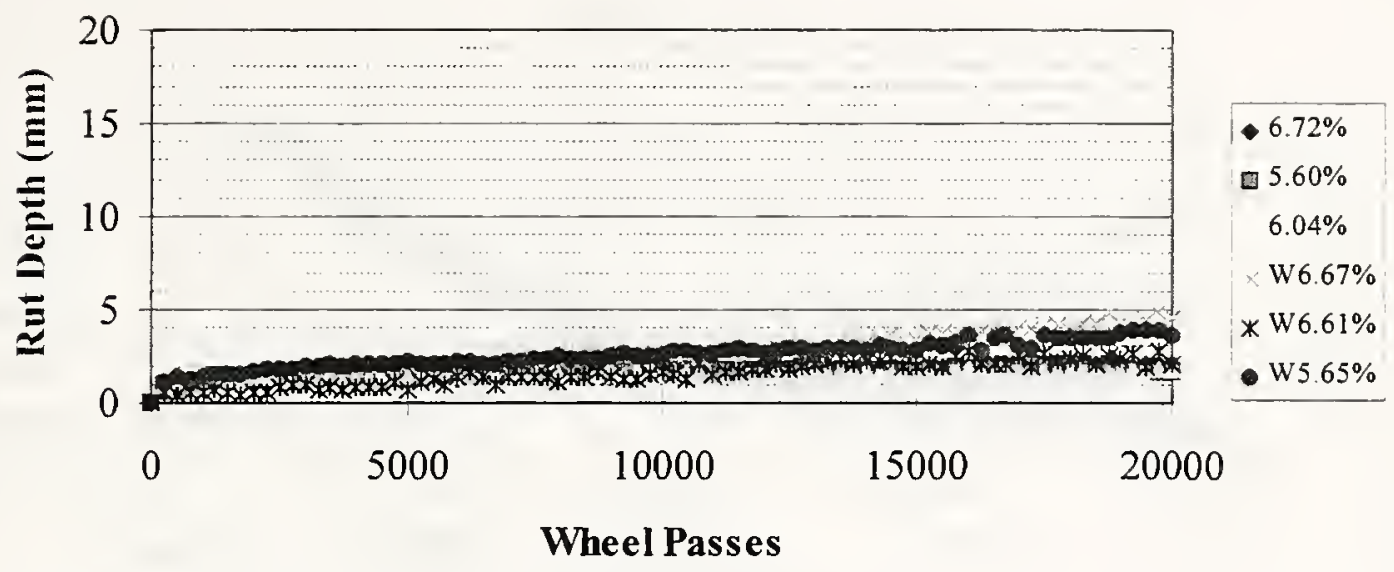

1. Legends represent $\%$ air void contents of the samples

2. "W" represents wet test conditions

Figure 6.5 Wheel Track Test Results of Dolomite Surface Mixture, $25^{\circ} \mathrm{C}$

\section{LCM}

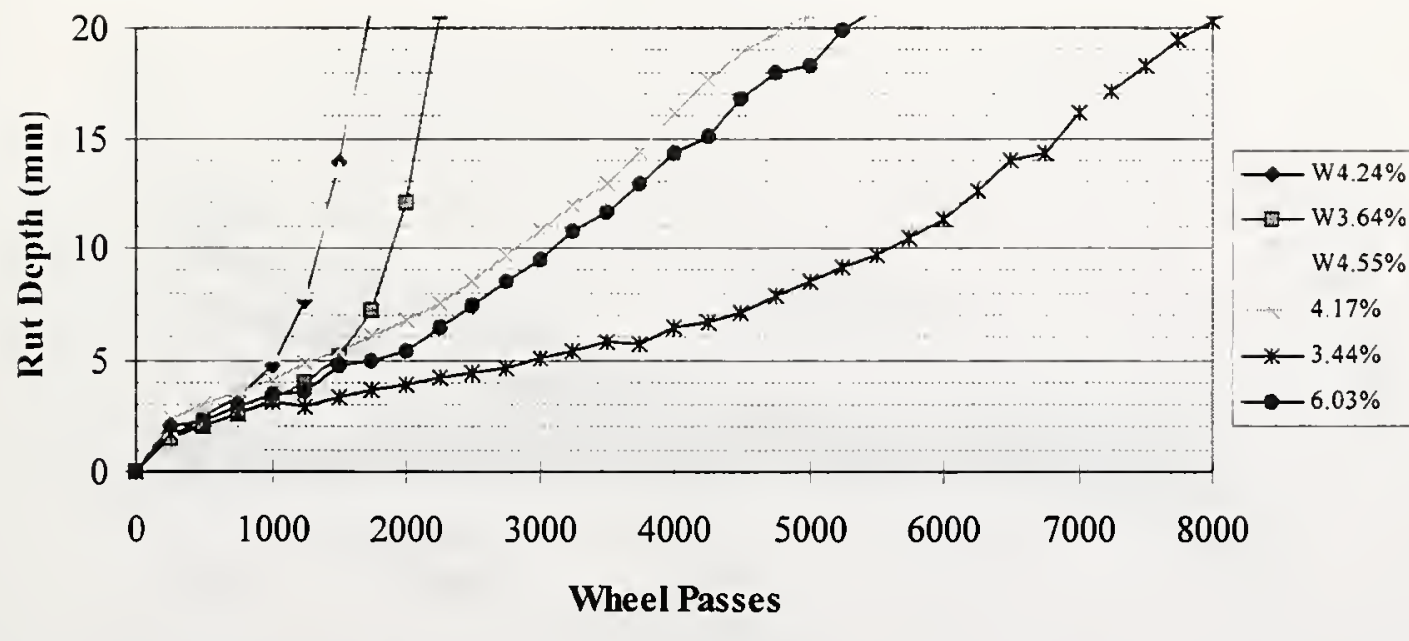

1. Legends represent \% air void contents of the samples

2. "W" represents wet test conditions

Figure 6.6 Wheel Track Test Results of Limestone Surface Mixture, $60^{\circ} \mathrm{C}$ 


\section{LCM 50 deg.}

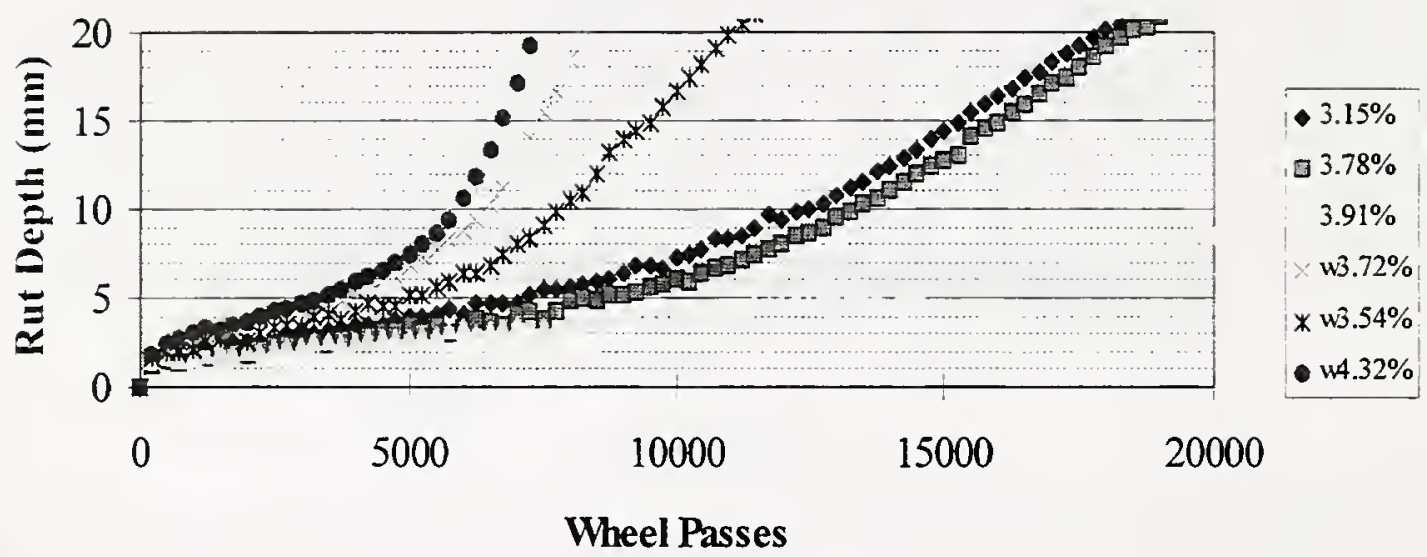

1. Legends represent \% air void contents of the samples

2. "W" represents wet test conditions

Figure 6.7 Wheel Track Test Results of Limestone Surface Mixture, $50^{\circ} \mathrm{C}$

\section{LCM 40 deg.}

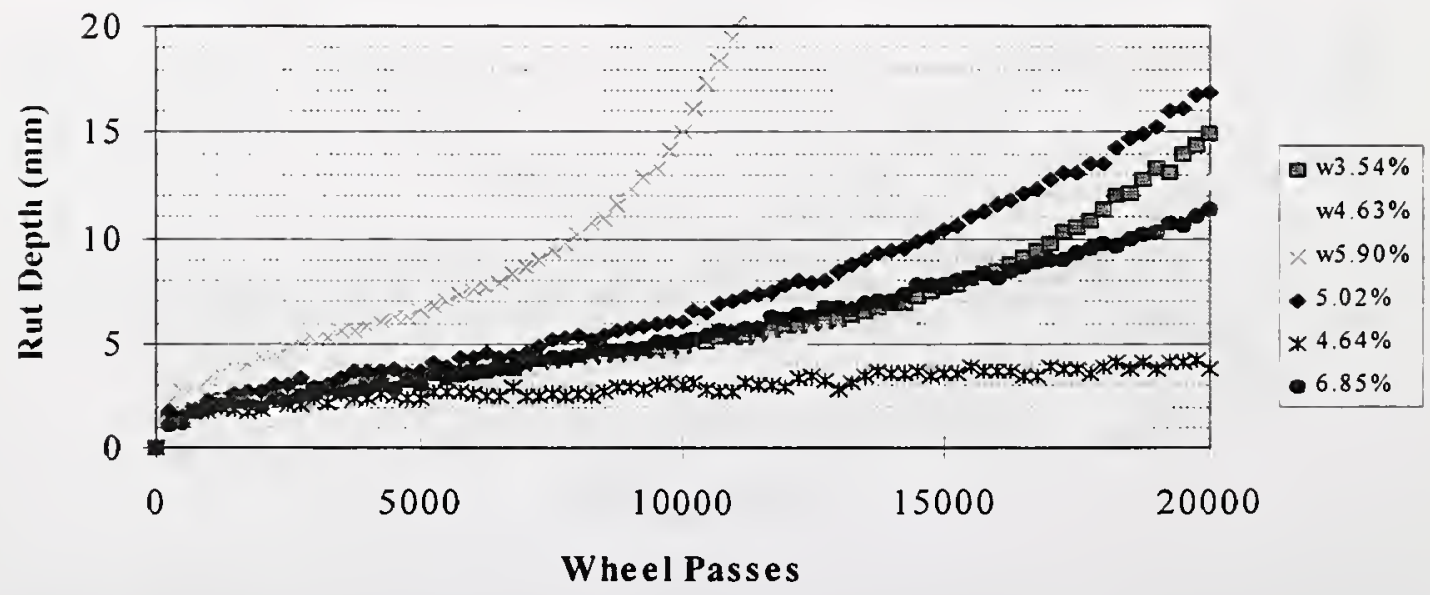

1. Legends represent $\%$ air void contents of the samples

2. " $W$ " represents wet test conditions

Figure 6.8 Wheel Track Test Results of Limestone Surface Mixture, $40^{\circ} \mathrm{C}$ 
\#11 Limestone, $30 \mathrm{Deg}$.

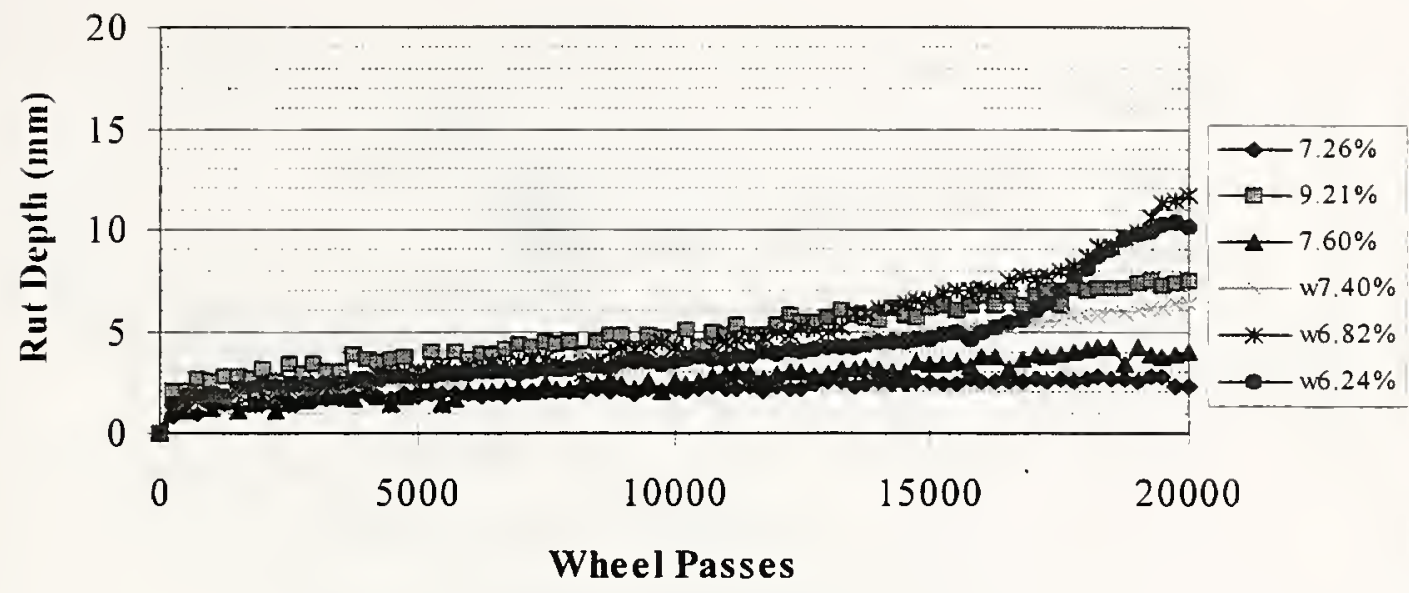

1. Legends represent $\%$ air void contents of the samples

2. "W" represents wet test conditions

Figure 6.9 Wheel Track Test Results of Limestone Surface Mixture, $30^{\circ} \mathrm{C}$

\section{LCM, 25 Degree}

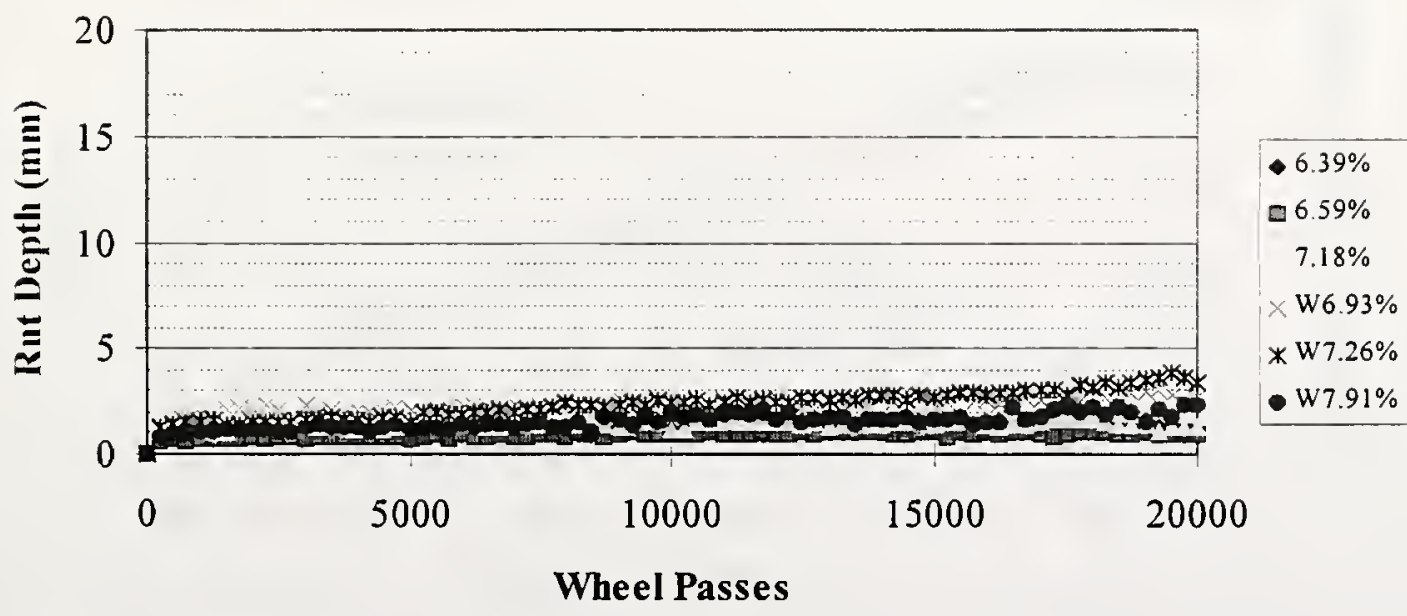

1. Legends represent $\%$ air void contents of the samples

2. "W" represents wet test conditions

Figure 6.10 Wheel Track Test Results of Limestone Surface Mixture, $25^{\circ} \mathrm{C}$ 
\#11 Limestone

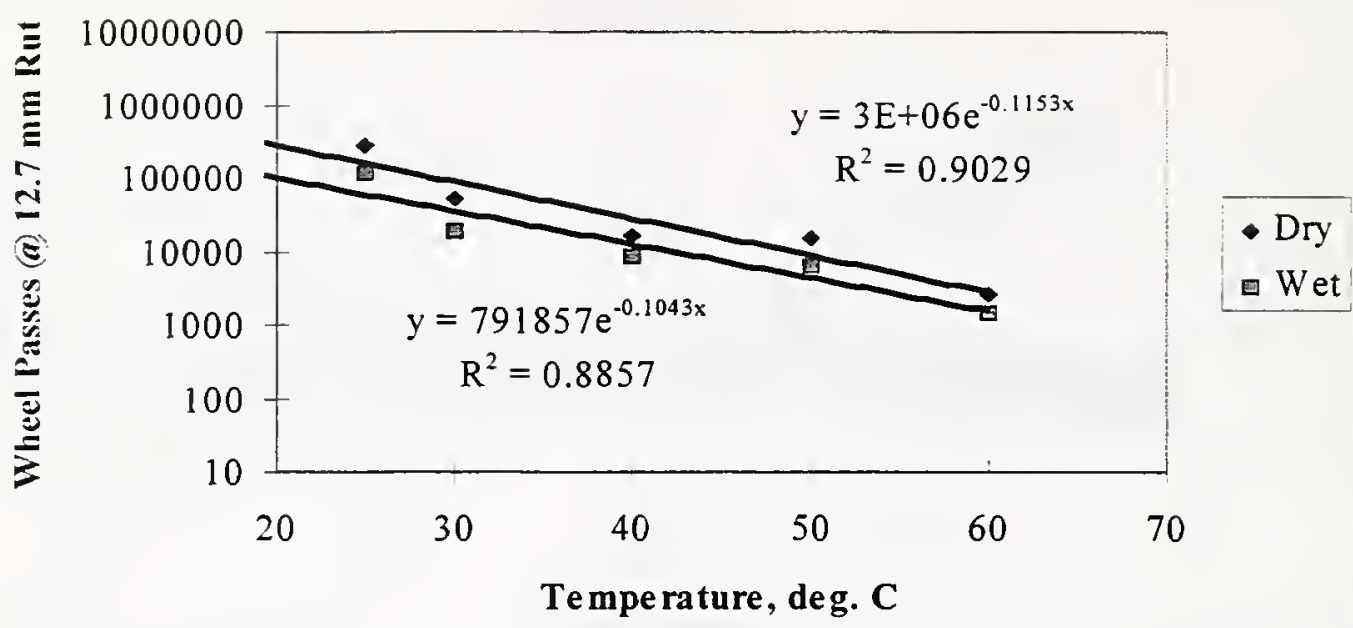

Figure 6.11 Temperature-Rutting Rate Relationship for \#11 Limestone Mix

\section{\#11 Dolomite}

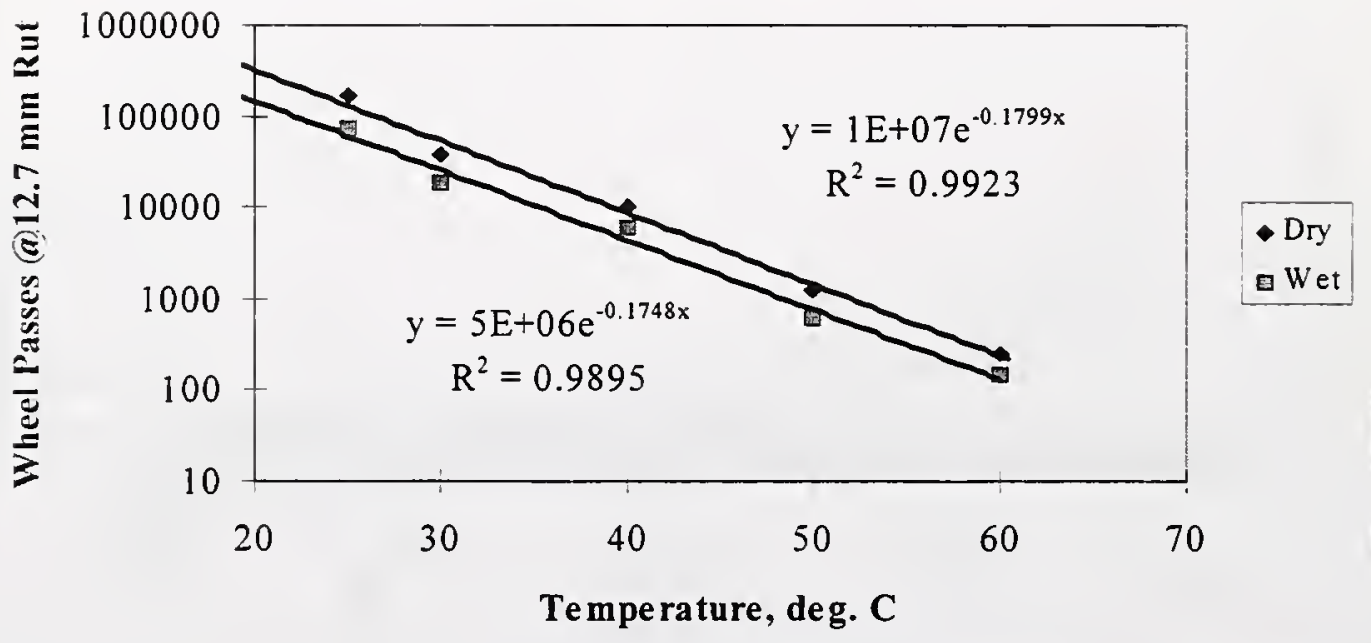

Figure 6.12 Temperature-Rutting Rate Relationship for \#11 Dolomite Mix 


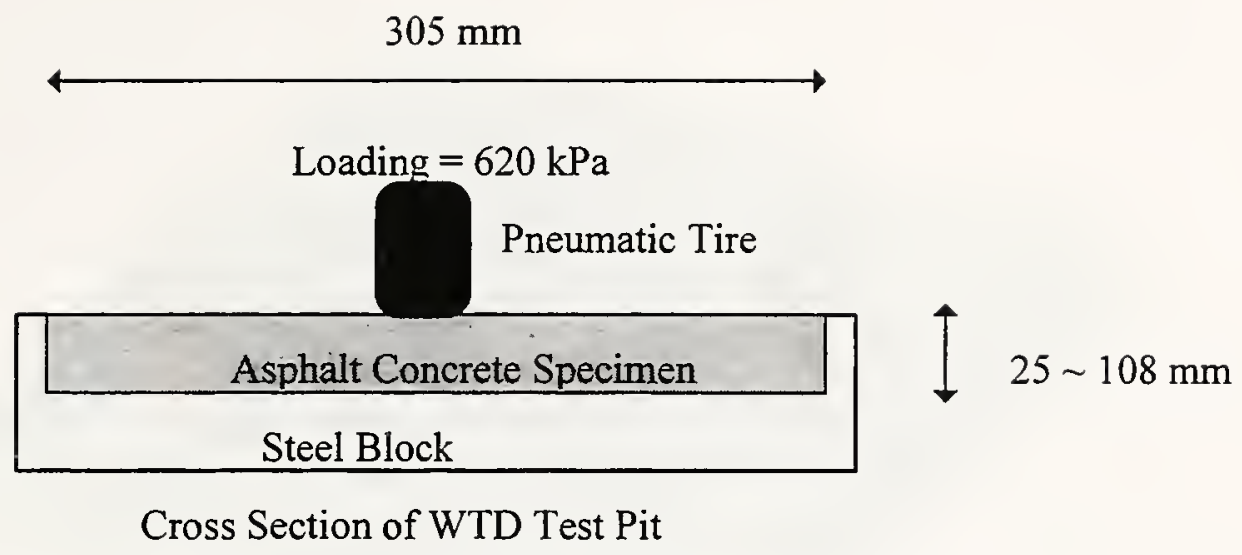

Figure 6.13 Cross Section of PURWheel Test Pit 


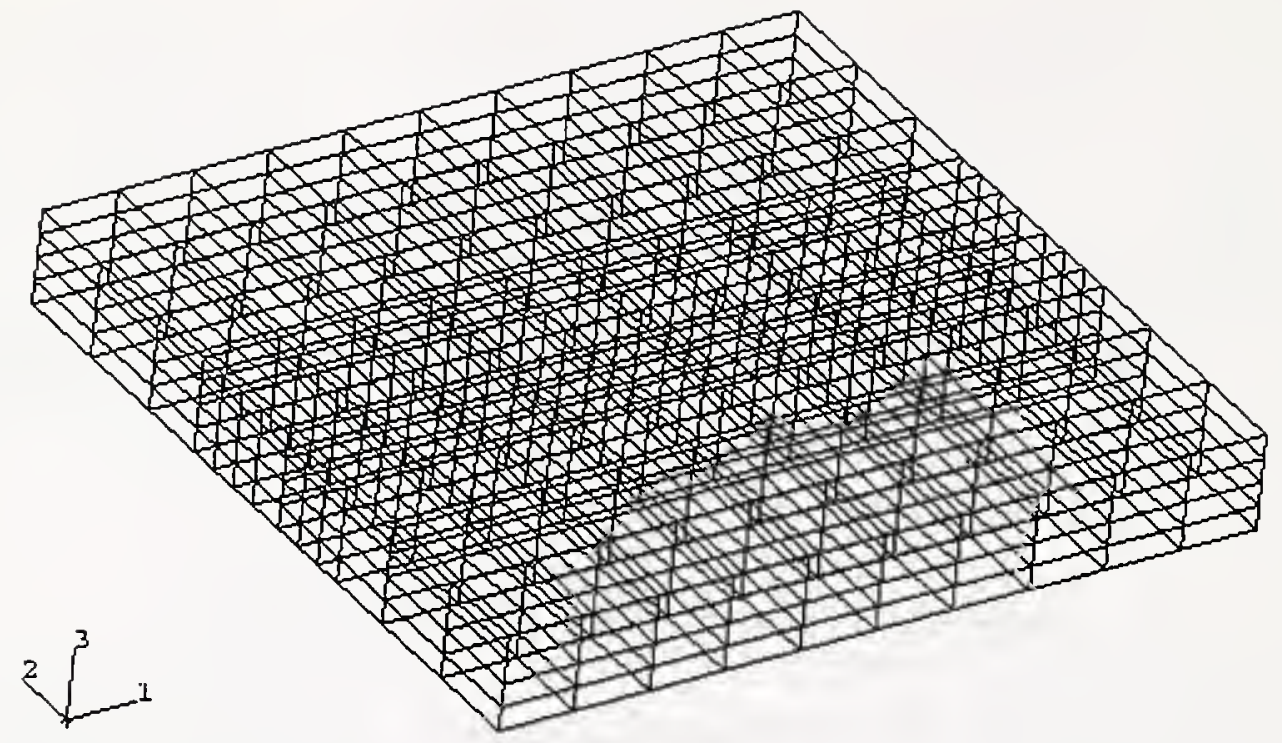

Figure 6.14 3-D View of Finite Element Mesh 


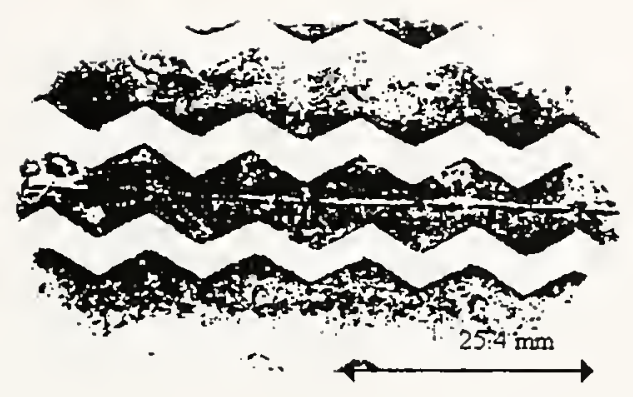

Figure 6.15 PURWheel Tire Print 


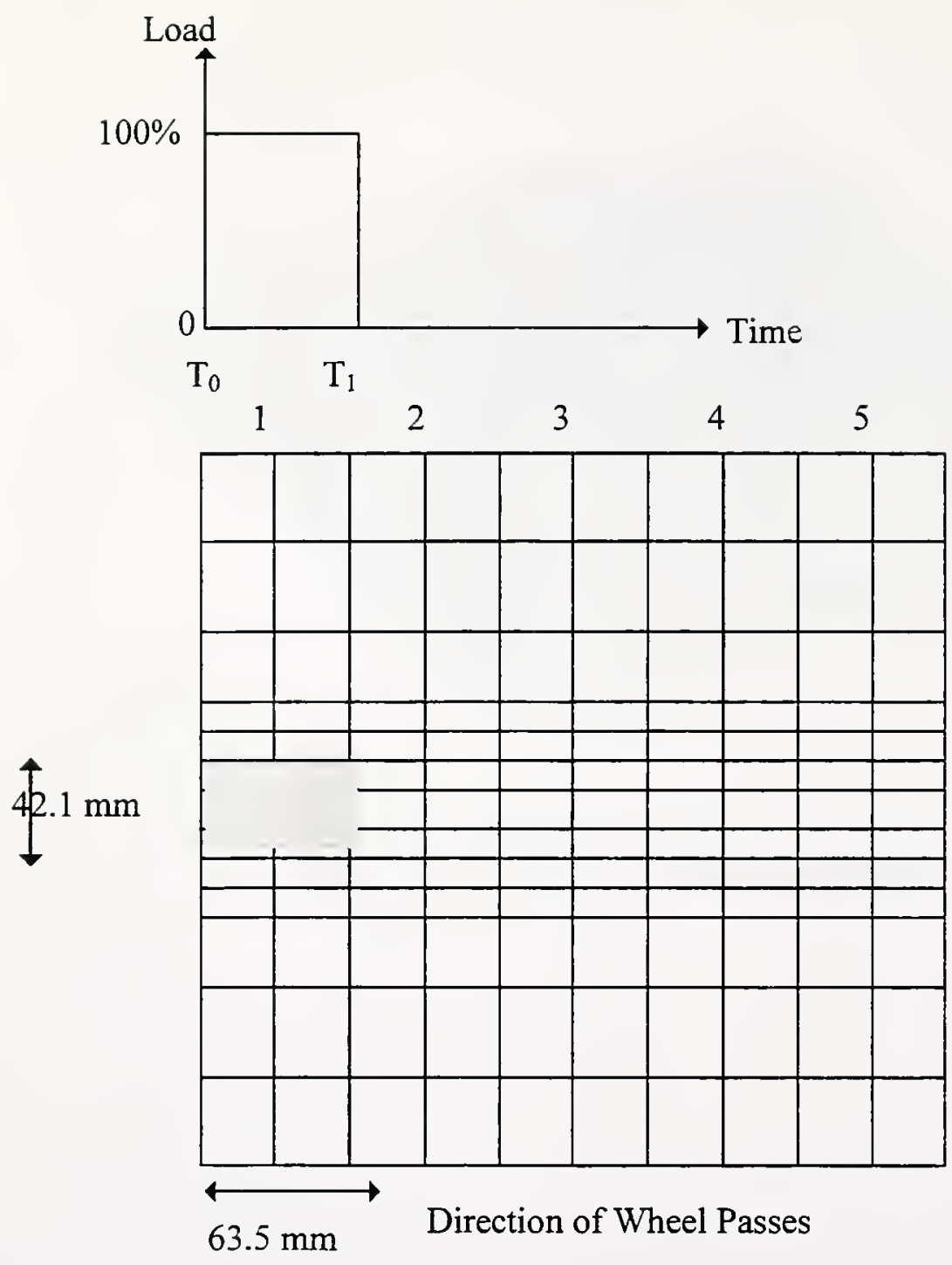

Figure 6.16 Step Load Function in the FEM. Analysis 

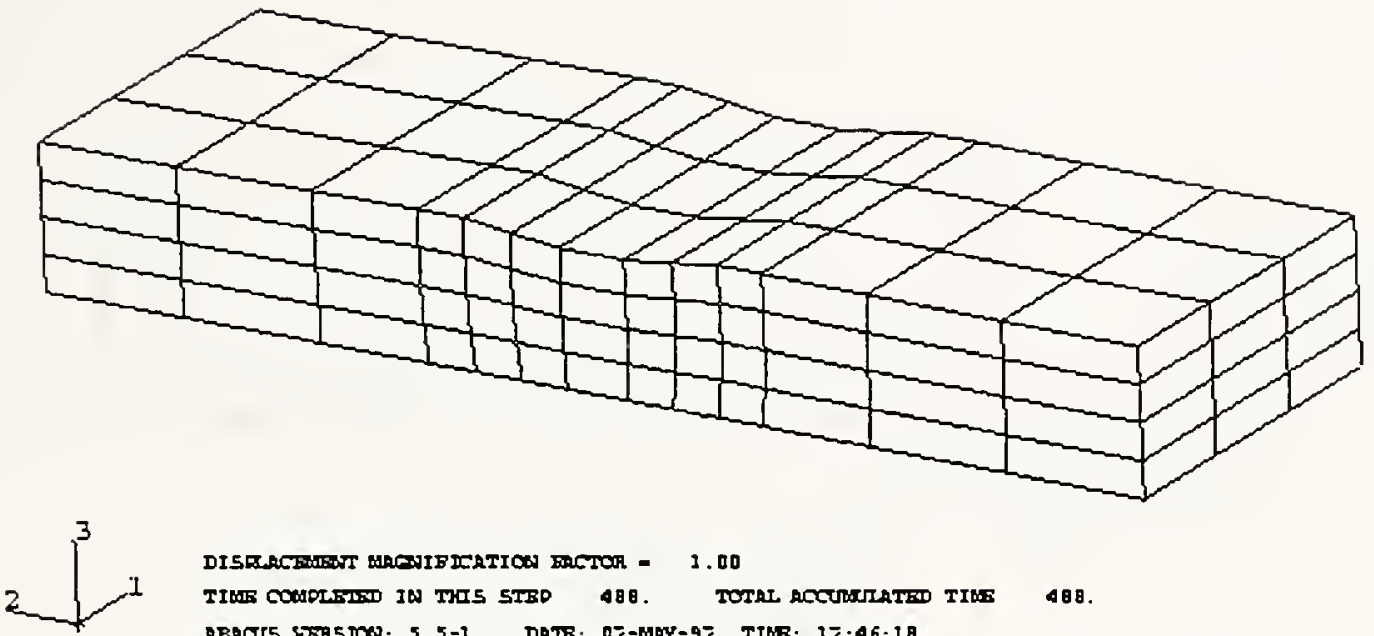

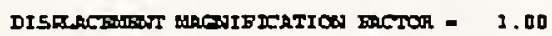

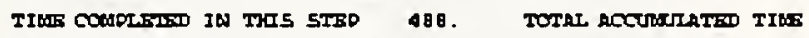

488.

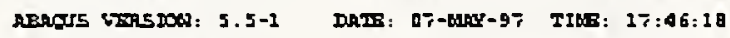

5TED 1 INCFHAB 80

Figure 6.17 Permanent Deformation Response of the Finite Element Model (Cross

Section View) 
8GCM $40 \mathrm{C}$

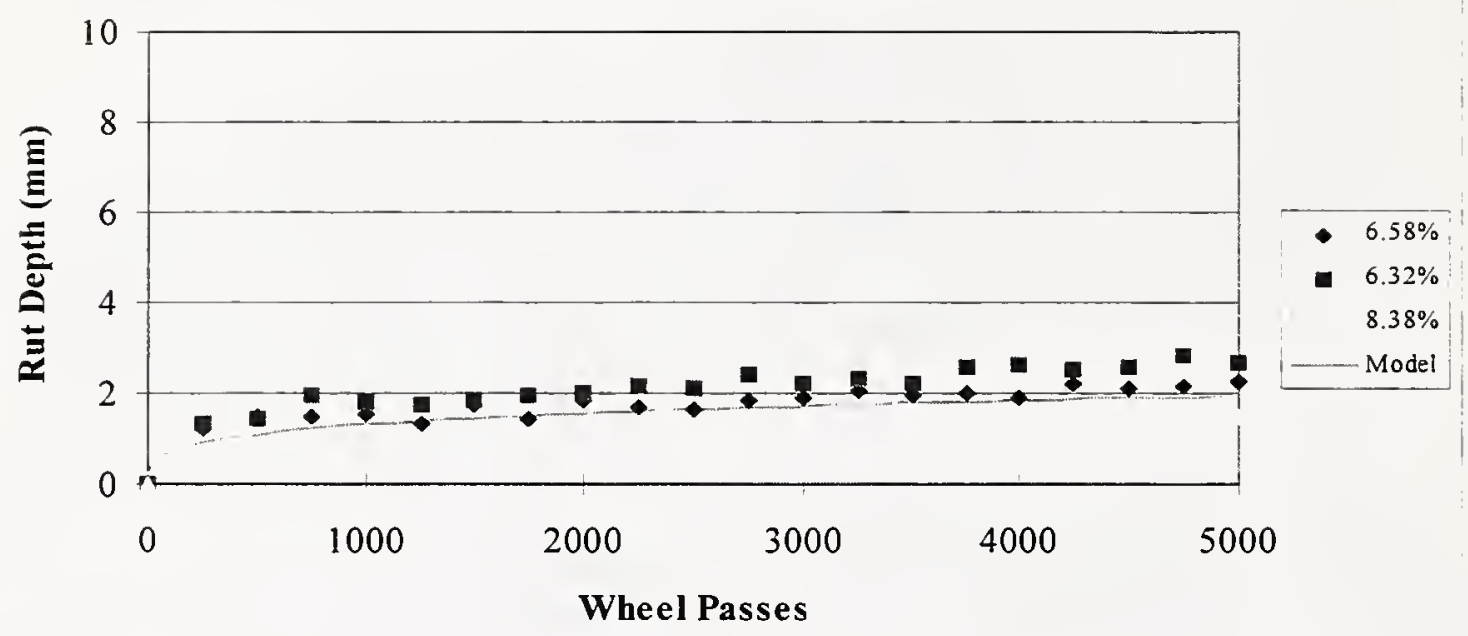

Figure 6.18 Creep Model Fitted Curves (\#8 Gravel Mix)

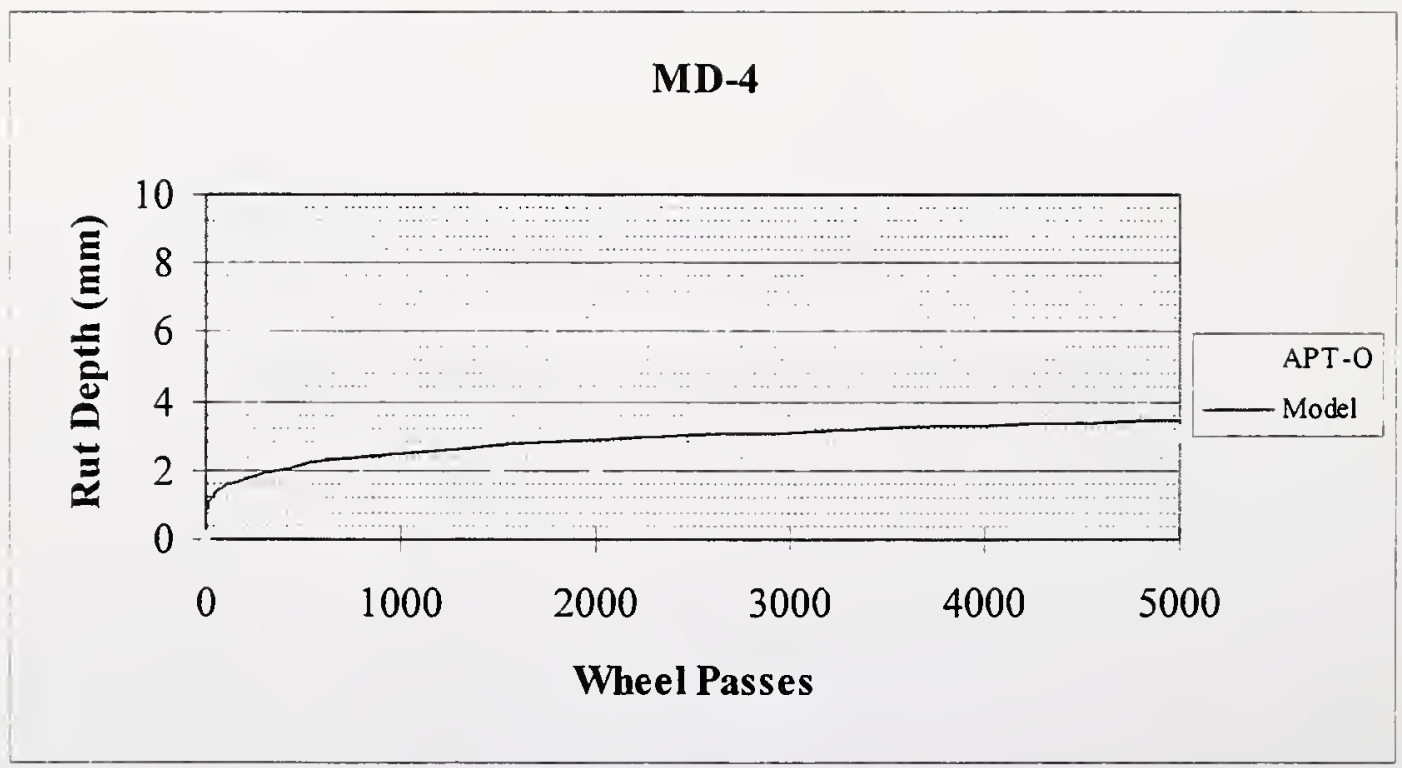

Figure 6.19 APT Test Results and Predicted Deformation Curves 
11LCM 60 C

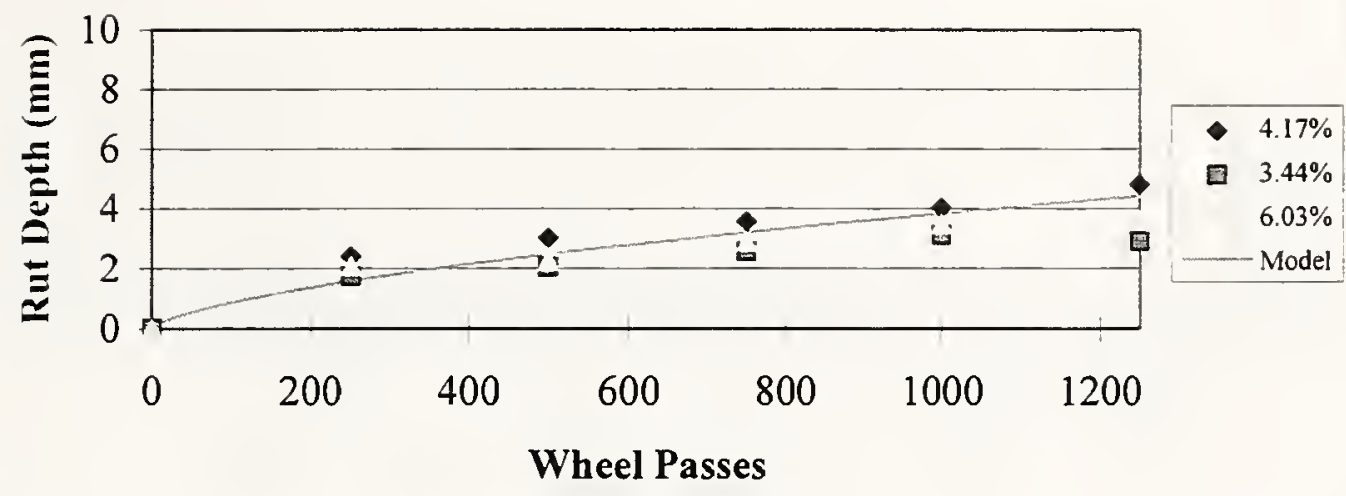

Figure 6.20 Fitted Curves (\#11 Limestone Surface Mixture, $60^{\circ} \mathrm{C}$ )

11 LCM 50 C

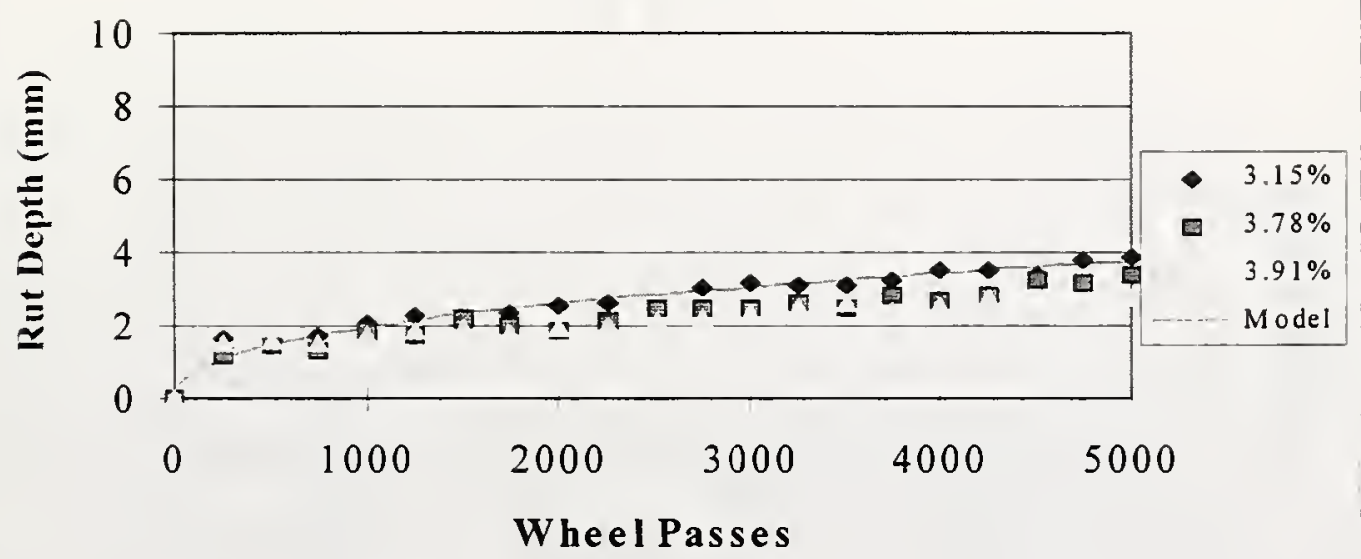

Figure 6.21 Fitted Curves (\#11 Limestone Surface Mixture, $50^{\circ} \mathrm{C}$ ) 


\section{LCM $40 \mathrm{C}$}

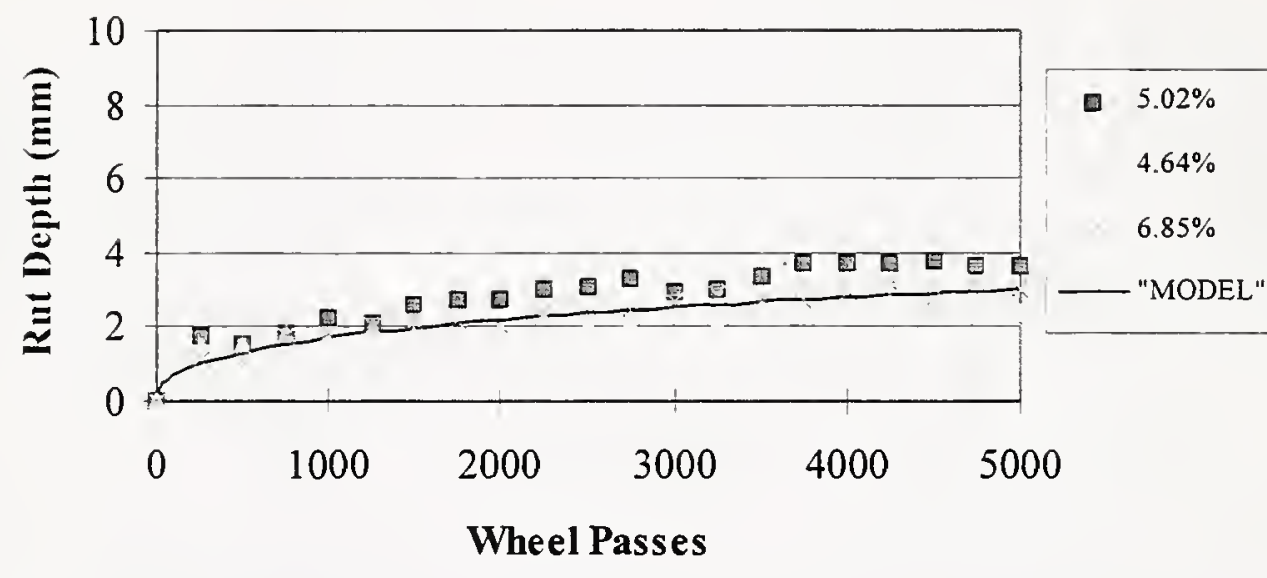

Figure 6.22 Fitted Curves ( $\# 11$ Limestone Surface Mixture, $40^{\circ} \mathrm{C}$ )

$11 \mathrm{LCM} 30 \mathrm{C}$

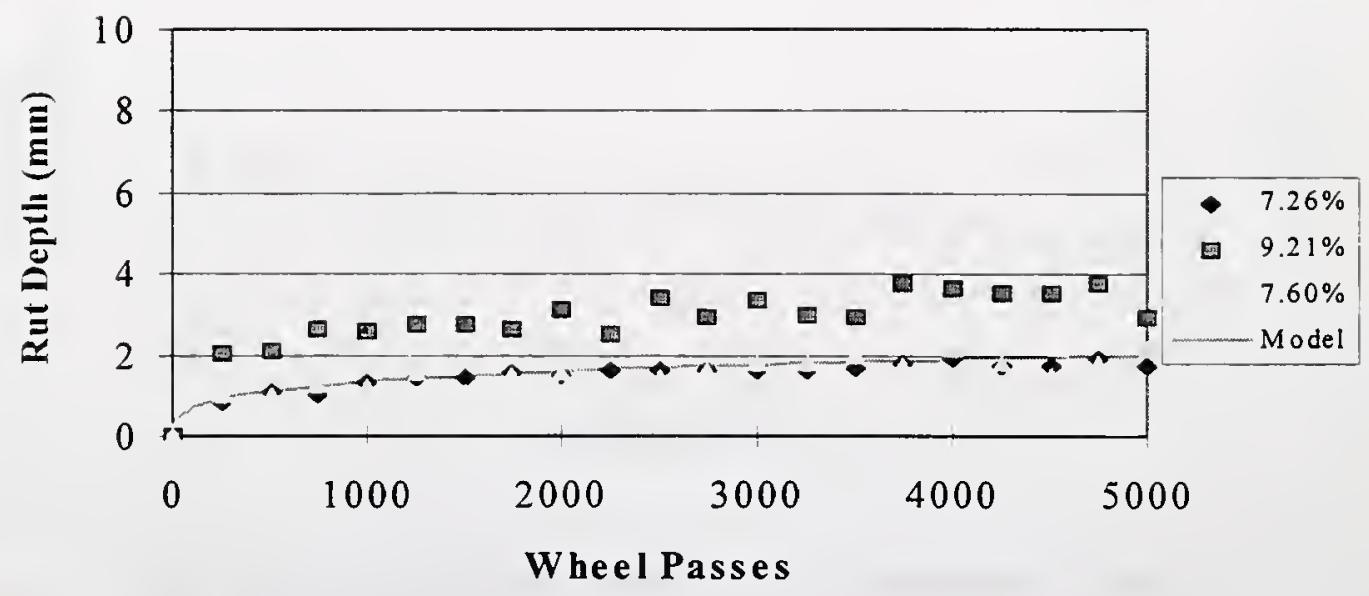

Figure 6.23 Fitted Curves (\#11 Limestone Surface Mixture, $30^{\circ} \mathrm{C}$ ) 
11LCM $25 \mathrm{C}$

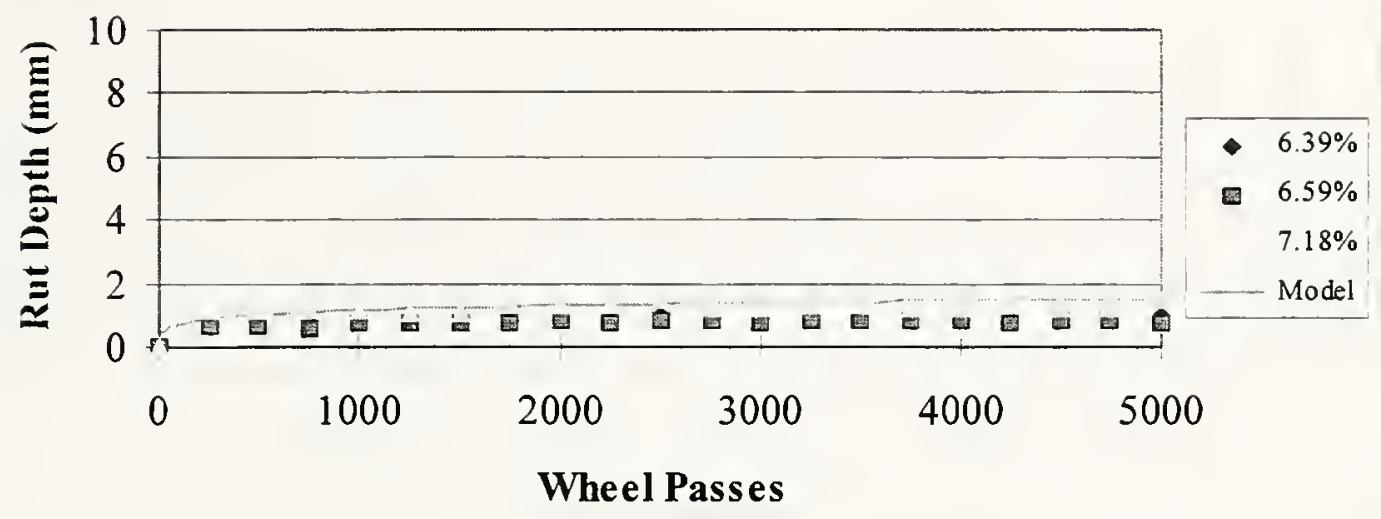

Figure 6.24 Fitted Curves (\#11 Limestone Surface Mixture, $25^{\circ} \mathrm{C}$ )

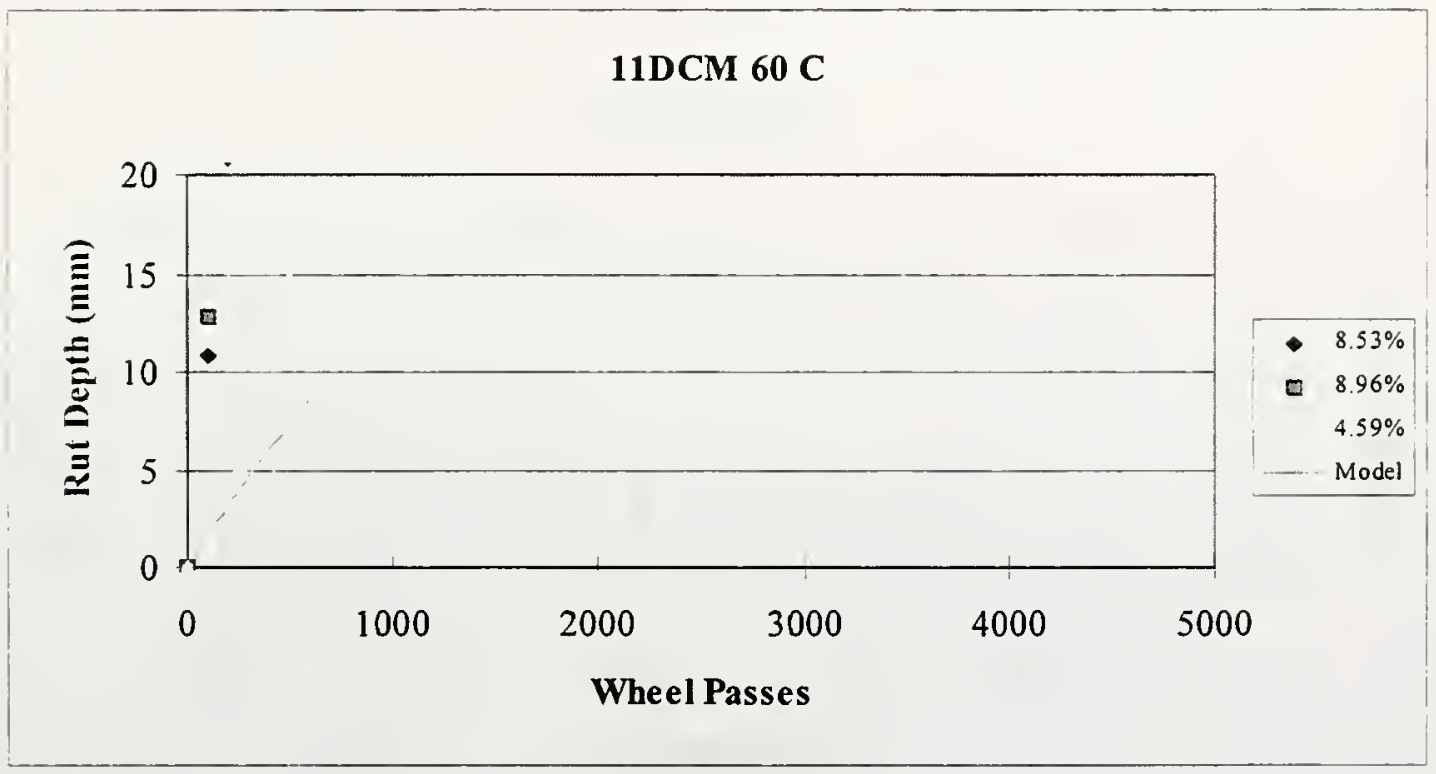

Figure 6.25 Fitted Curves (\#11 Dolomite Surface Mixture, $60^{\circ} \mathrm{C}$ ) 


\section{DCM $50 \mathrm{C}$}

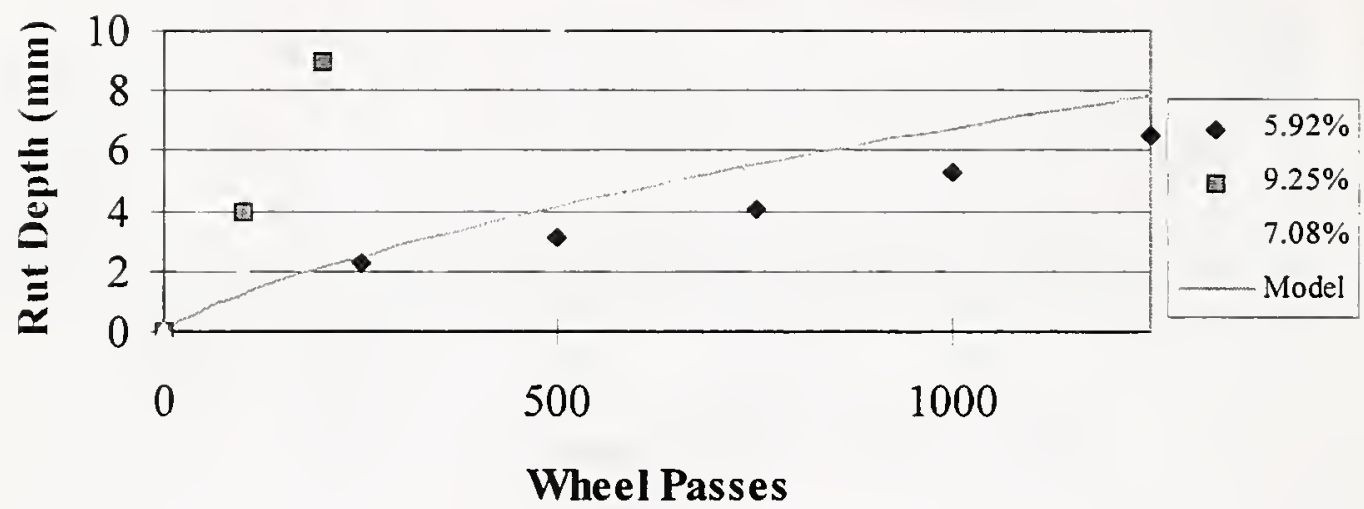

Figure 6.26 Fitted Curves (\#11 Dolomite Surface Mixture, $50^{\circ} \mathrm{C}$ )

\section{DCM $40 \mathrm{C}$}

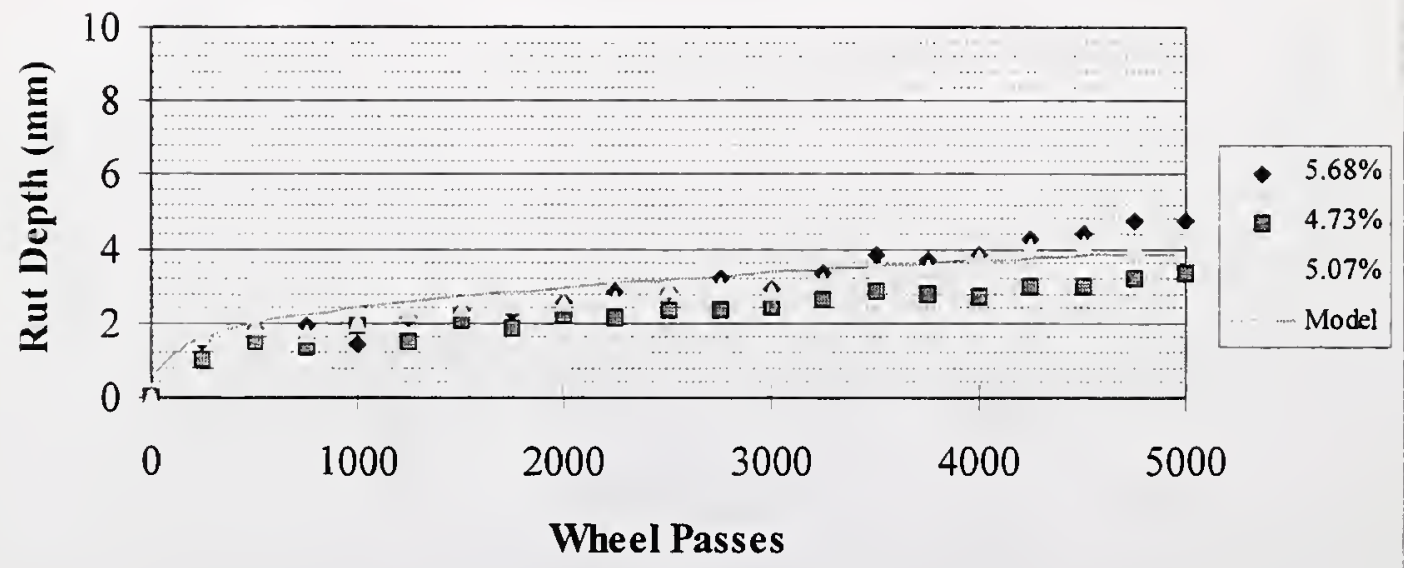

Figure 6.27 Fitted Curves (\#11 Dolomite Surface Mixture, $40^{\circ} \mathrm{C}$ ) 
11DCM $30 \mathrm{C}$

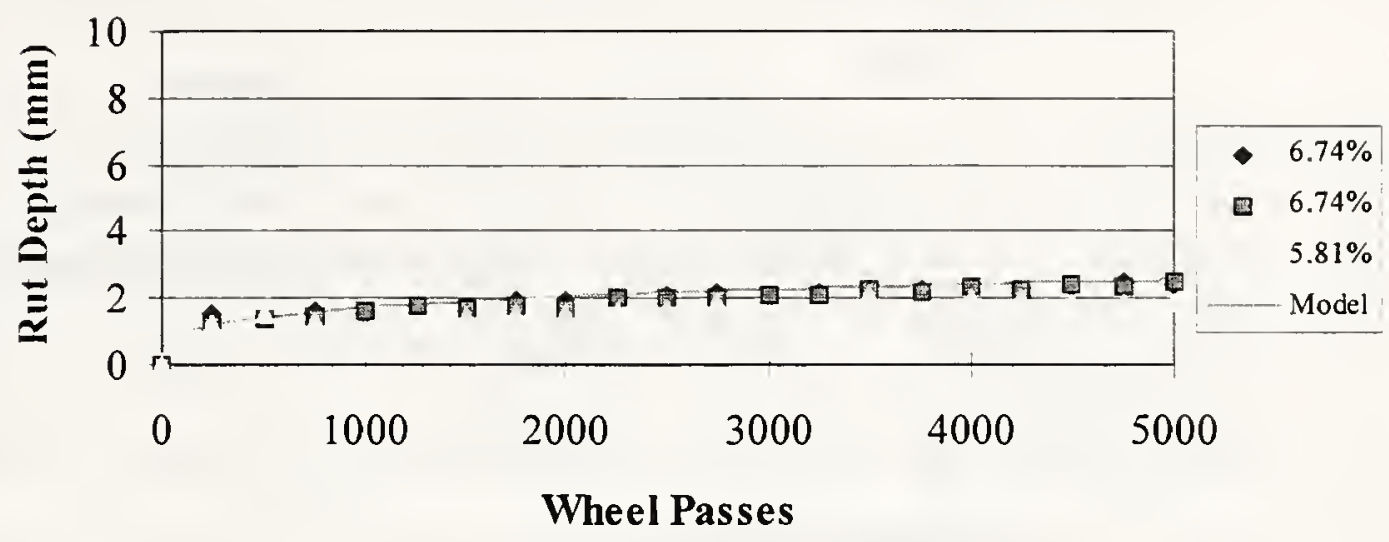

Figure 6.28 Fitted Curves (\#11 Dolomite Surface Mixture, $30^{\circ} \mathrm{C}$ )

11DCM $25 \mathrm{C}$

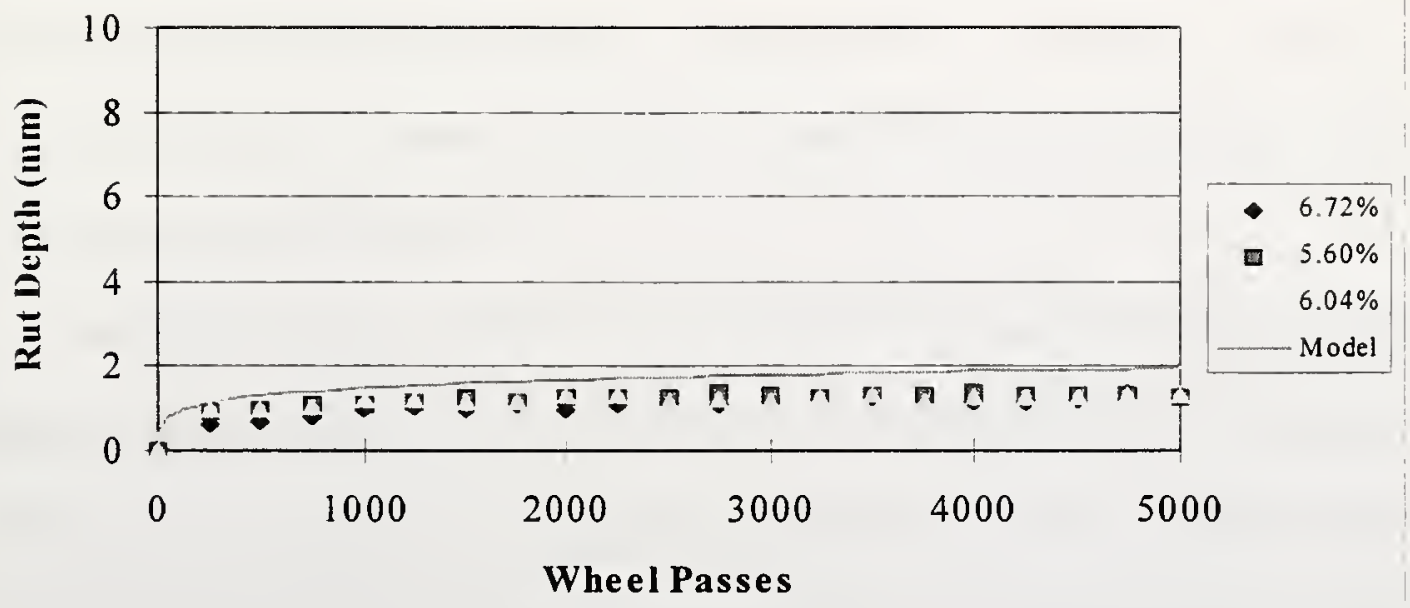

Figure 6.29 Fitted Curves (\#11 Dolomite Surface Mixture, $25^{\circ} \mathrm{C}$ ) 


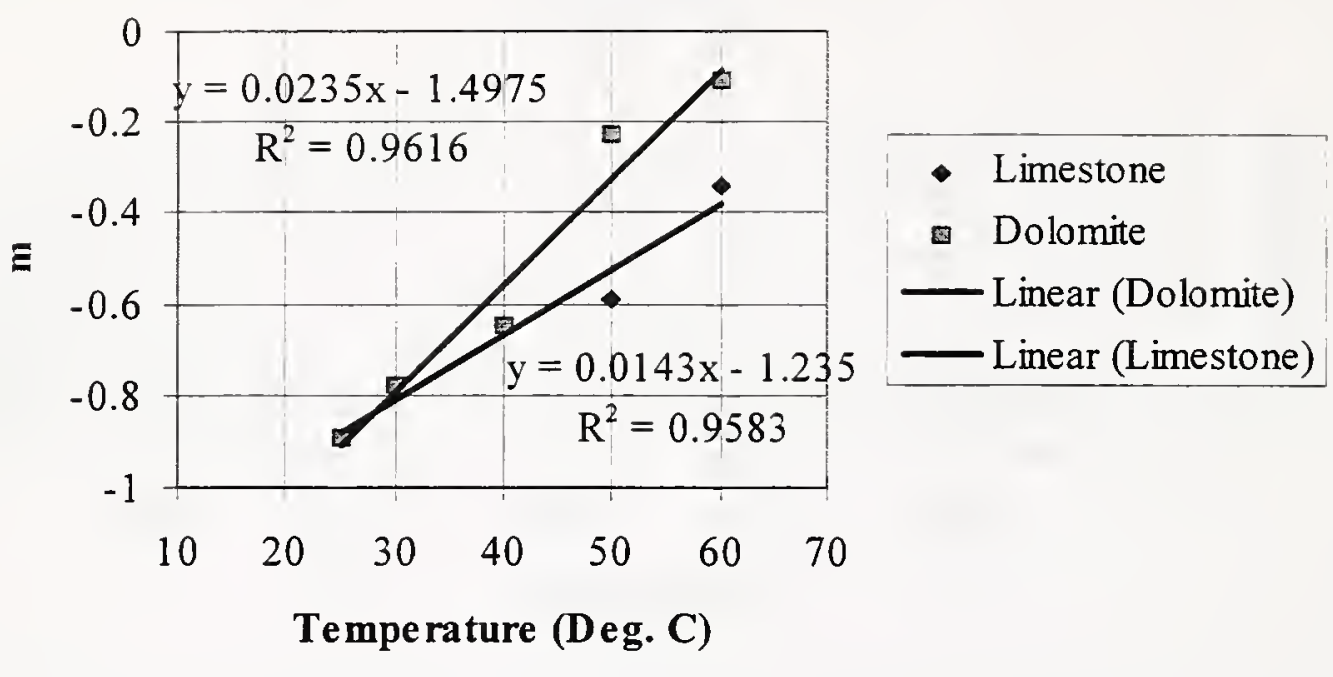

Figure 6.30 Effect of Temperature on Parameter $m$ 


\section{CHAPTER 7 EVALUATIONS OF 1996 SUPERPAVE PROJECTS}

After five years of research, the Strategic Highway Research Program (SHRP) produced the Superpave (Superior Performing Asphalt Pavements) asphalt specification and mix design system. The Superpave mix design component is a comprehensive method of designing paving mixes based on performance requirements established by the traffic, environmental conditions, and pavement structural section at any particular pavement site (Cominsky et al., 1994). The basic concept of the Superpave mix design method is to enhance pavement performance through the selection of the asphalt binder and aggregates that achieve a desired level of performance. As originally proposed, the Superpave mix design method included a volumetric design for limited traffic. For medium and high volume traffic the volumetric mix design was to be combined with a more complete analysis of the mixture including shear and indirect tensile tests. However, the Superpave volumetric mix design method is currently being used to design mixtures for all levels of traffic.

One of the objectives of this study is to evaluate the stripping/rutting potential of Superpave mixtures using the Purdue laboratory wheel (PURWheel) tracking device (WTD) and to examine the possibility of using Superpave Gyratory Compactor (SGC) samples for the AASHTO T-283 test. In order to achieve this objective in a short period 
of time, six mixes from five different Superpave construction projects were included in the research. Two mixtures $(19.0 \mathrm{~mm}$ and $9.5 \mathrm{~mm})$ from the same project were tested.

\subsection{Asphalt Mixtures}

A summary of the Superpave mix designs included in the study are shown in Table 7.1. All six Superpave mixes were plant sampled materials and the mix design results were provided by the project contractors. Base on the Superpave mix design criteria, the design asphalt content for each mix was selected at $4 \%$ air voids.

\subsection{WTD Test Results}

Specimens prepared for WTD testing are compacted to $6 \sim 8 \%$ air voids with the Purdue linear compactor (described in Chapter Five). Specimen dimensions are typically $29.0 \mathrm{~cm}$ wide by $31.0 \mathrm{~cm}$ long. The thickness is $3.8 \mathrm{~cm}$ for $9.5 \mathrm{~mm}$ and $12.5 \mathrm{~mm}$ mixes and $5.1 \mathrm{~cm}$ for $19.0 \mathrm{~mm}$ and $25.0 \mathrm{~mm}$ mixes. A temperature of $60^{\circ} \mathrm{C}$ was selected for the $9.5 \mathrm{~mm}$ and $12.5 \mathrm{~mm}$ mix tests. For $19.0 \mathrm{~mm}$ and $25.0 \mathrm{~mm}$ mixes, the test temperature was selected at $57.5^{\circ} \mathrm{C}$. The test environment can be either hot/wet or hot/dry. A pneumatic tire is loaded to achieve a gross contact pressure of about $620 \mathrm{kPa}$ with a 793 $\mathrm{kPa}$ tire pressure. The wheel velocity selected for these tests was $34 \mathrm{~cm} / \mathrm{sec}(1.1 \mathrm{ft} / \mathrm{sec})$. In this study, each specimen was subjected to 20,000 wheel passes or until a $20.0 \mathrm{~mm}$ deformation developed. 
Results for the WTD tests are summarized in Table 7.2. Graphic results from WTD tests are shown in Figure 7.1 to Figure 7.6. Triplicate samples were prepared and tested to include the effect of sample variation. As previously described, a $12.7 \mathrm{~mm}$ rut depth criteria (Chapter Five) was applied in evaluating WTD results. The $12.7 \mathrm{~mm}$ total rut depth is equivalent to a transducer measured rut depth (deformation) of $8.9 \mathrm{~mm}$ in the PURWheel. Wheel passes at $6 \%$ air void contents to achieve the deformation criteria was interpolated from the triplicate tests. The wet/dry ratio is calculated from the ratio of wet and dry tests at $6 \%$ air voids.

The fine aggregate angularity of both R-22170 mixes was 40 percent. Mixtures for project R-22170 were designed for a traffic level of less than three million ESALs. These two mixes exhibited the poorest performance of mixtures tested. The fine aggregate angularity of the other four mixtures was 45 or higher. Examination of the PURWheel results show that a higher percentage of natural sand causes progressively poorer performance.

\subsection{AASHTO T-283 Test}

Results from AASHTO T-283 tests are summarized in Table 7.3 and Table 7.4 for the $102 \mathrm{~mm}$ and $150 \mathrm{~mm}$ specimens, respectively. Test procedures for preparing and testing $102 \mathrm{~mm}$ specimens was previously described in Chapter Four. The $150 \mathrm{~mm}$ specimens were prepared using a Superpave gyratory compactor. Subsequently, these specimens were tested using the same test procedures as those used for the $102 \mathrm{~mm}$ 
specimens. The tensile strength ratios (TSR) of the six Superpave mixes are all above 80 percent (minimum Superpave TSR). In fact, the TSR values range from 85 to 94 for the $102 \mathrm{~mm}$ specimens and 91 to 103 for the $150 \mathrm{~mm}$ specimens.

The TSR results for the six Superpave mixes are shown in Figure 7.7. Most of the mixes have a higher TSR value when the test was conducted using $150 \mathrm{~mm}$ SGC specimens. This might due to the fact that the larger specimens are less affected by the conditioning procedures. The test results also show the larger specimens $(150 \mathrm{~mm})$ have lower tensile strength than the $102 \mathrm{~mm}$ specimens (Table 7.3 and Table 7.4). This means the tensile strength is related to the specimen size. More evaluation is needed prior to adoption of SGC specimens for testing in AASHTO T-283.

\subsection{Summary}

Results from WTD and AASHTO T-283 tests for the Superpave mixes show the stripping/rutting potential of the mix can be minimized through better selection of materials as well as the mixture gradations. The fine aggregate angularity and/or gradation appear to be related to the mixture instability. Comparison of the TSR results for the $102 \mathrm{~mm}$ and $150 \mathrm{~mm}$ specimens indicates that $102 \mathrm{~mm}$ specimens are more sensitive to the current moisture conditioning procedures. Application of the $150 \mathrm{~mm}$ SGC specimen for AASHTO T-283 test still needs further evaluation before modification of the current test standard. 
Table 7.1 Summary of Superpave Volumetric Mix Design Results

\begin{tabular}{|c|c|c|c|c|c|c|}
\hline Project No. ${ }^{(1)}$ & R-21467 & $\mathrm{R}-22350$ & R-22687 & R-22403 & R-22170 & $\mathrm{R}-22170$ \\
\hline Mix Type & $12.5 \mathrm{~mm} \mathrm{HV}$ & $9.5 \mathrm{~mm} \mathrm{HV}$ & $25.0 \mathrm{~mm} \mathrm{HV}$ & $19.0 \mathrm{~mm} \mathrm{HV}$ & $19.0 \mathrm{~mm} \mathrm{MV}$ & $9.5 \mathrm{~mm} \mathrm{MV}$ \\
\hline Binder Grade & PG 58-28 & PG 58-34 & PG 58-34 & PG 70-28 & PG 58-28 & PG 58-28 \\
\hline Asphalt Content & 5.3 & 6.3 & 4.6 & 5.4 & 4.5 & 5.6 \\
\hline Max. Spec. Gravity & 2.606 & 2.428 & 2.522 & 2.469 & 2.470 & 2.505 \\
\hline $\mathrm{VMA}^{(2)}$ & 14.9 & 16.6 & 13.0 & 14.5 & 13.7 & 16.2 \\
\hline $\mathrm{VFA}^{(3)}$ & 72.9 & 73.8 & 68.0 & 72.1 & 71.6 & 72.7 \\
\hline $\mathrm{FAA}^{(4)}$ & 47.8 & 46.3 & 45.5 & 45.1 & 40.0 & 40.0 \\
\hline Sand Equivalency & 94.0 & 70.6 & 93.5 & 94.0 & 95.9 & 96.0 \\
\hline Dust/Asp. Ratio & 0.9 & 0.9 & 0.9 & 1.2 & 0.9 & 0.6 \\
\hline $\mathrm{TSR}^{(5)}, \%$ & 90.9 & 83.5 & 95.0 & 90.1 & 92.0 & 86.0 \\
\hline
\end{tabular}

1. Mix design results provided by contractor

2. VMA : Voids in Mineral Aggregate

3. VFA : Voids Filled with Asphalt

4. FAA : Fine Aggregate Angularity

5. TSR : Tensile Strength Ratio 
Table 7.2 Summary of WTD Test Results (at $12.7 \mathrm{~mm}$ Rut)

\begin{tabular}{|c|c|c|c|c|c|}
\hline Project No. & $\begin{array}{c}\text { Dry Test } \\
\text { (Air voids, \%) }\end{array}$ & $\begin{array}{l}\text { Est. Passes @ } \\
6 \% \text { Air Voids }\end{array}$ & $\begin{array}{c}\text { Wet Test } \\
\text { (Air voids, \%) }\end{array}$ & $\begin{array}{l}\text { Est. Passes @ } \\
6 \% \text { Air Voids }\end{array}$ & $\begin{array}{c}\text { Wet/Dry } \\
\text { Ratio }\end{array}$ \\
\hline $\begin{array}{c}\mathrm{R} 21467-12.5 \mathrm{~mm} \\
(\mathrm{FAA}=48)\end{array}$ & $\begin{array}{l}50733(7.68) \\
36662(7.43) \\
29081(10.2)\end{array}$ & 51236 & $\begin{array}{c}20000(7.62) \\
6250(7.87) \\
3250(9.39)\end{array}$ & 25514 & 0.50 \\
\hline $\begin{array}{c}\mathrm{R} 22350-9.5 \mathrm{~mm} \\
(\mathrm{FAA}=46)\end{array}$ & $\begin{array}{c}57448(7.78) \\
57400(7.57) \\
124000(7.31)\end{array}$ & 110818 & $\begin{array}{c}12500(8.03) \\
28356(7.57) \\
8750(6.80)\end{array}$ & 8768 & 0.08 \\
\hline $\begin{array}{l}\text { R22170-9.5 mm } \\
(\mathrm{FAA}=40)\end{array}$ & $\begin{array}{l}1064(6.95) \\
1205(7.27) \\
4099(5.03)\end{array}$ & 2703 & $\begin{array}{l}214(5.67) \\
224(6.57) \\
201(8.68)\end{array}$ & 218 & 0.08 \\
\hline $\begin{array}{c}\mathrm{R} 22403-19.0 \mathrm{~mm} \\
(\mathrm{FAA}=45)\end{array}$ & $\begin{array}{c}177630(2.53) \\
58973(5.61) \\
107167(5.57)\end{array}$ & 70274 & $\begin{array}{l}61830(6.08) \\
25464(8.95) \\
32872(4.84)\end{array}$ & 42371 & 0.60 \\
\hline $\begin{array}{c}\mathrm{R} 22170-19.0 \mathrm{~mm} \\
(\mathrm{FAA}=40)\end{array}$ & $\begin{array}{c}186280(6.21) \\
70118(6.29) \\
110047(5.69)\end{array}$ & 121554 & $\begin{array}{l}16500(7.03) \\
17000(5.18) \\
35786(8.69)\end{array}$ & 18009 & 0.15 \\
\hline $\begin{array}{c}\mathrm{R} 22687-25.0 \mathrm{~mm} \\
(\mathrm{FAA}=46)\end{array}$ & $\begin{array}{l}110113(8.2) \\
139243(9.2) \\
90780(10.2)\end{array}$ & 144311 & $\begin{array}{l}60380(6.08) \\
25231(8.75) \\
33210(6.84)\end{array}$ & 53873 & 0.37 \\
\hline
\end{tabular}


Table 7.3 AASHTO T-283 Test Results (102 mm specimens)

\begin{tabular}{|c|c|c|c|c|c|c|c|c|}
\hline & \multicolumn{3}{|c|}{ Dry } & \multicolumn{4}{|c|}{ Wet } & \multirow[b]{2}{*}{$\begin{array}{c}\text { TSR, } \\
\%\end{array}$} \\
\hline & $\begin{array}{c}\text { Air Voids, } \\
\%\end{array}$ & $\begin{array}{l}\text { ITS } \\
(\mathrm{kPa})\end{array}$ & \begin{tabular}{|c|} 
ITS $_{\text {(Average) }}$ \\
$(\mathrm{kPa})$
\end{tabular} & $\begin{array}{c}\text { Air Voids, } \\
\%\end{array}$ & $\begin{array}{c}\text { Saturation, } \\
\%\end{array}$ & $\begin{array}{l}\text { ITS, } \\
(\mathrm{kPa})\end{array}$ & \begin{tabular}{|c|} 
ITS $_{\text {(Average) }}$ \\
$\%$
\end{tabular} & \\
\hline & 8.07 & 1326 & & 7.43 & 64 & 1307 & & \\
\hline R21467 & 7.08 & 1532 & 1402 & 7.01 & 62 & 1241 & 1247 & 89 \\
\hline Surface & 7.47 & 1347 & & 8.33 & 65 & 1193 & & \\
\hline & 7.73 & 658 & & 7.40 & 63 & 610 & & \\
\hline R22350 & 6.18 & 659 & 659 & 6.88 & 64 & 624 & 597 & 91 \\
\hline Surface & 7.83 & 659 & & 7.34 & 65 & 560 & & \\
\hline & 6.64 & 784 & & 6.89 & 79 & 684 & & \\
\hline R22170 & 6.88 & 789 & 798 & 5.90 & 66 & 774 & 695 & 87 \\
\hline Surface & 5.89 & 820 & & 6.00 & 61 & 627 & & \\
\hline & 5.70 & 685 & & 6.51 & 59 & 553 & & \\
\hline R22403 & 5.86 & 676 & 681 & 5.54 & 61 & 589 & 582 & 86 \\
\hline Binder & 8.65 & 681 & & 5.44 & 70 & 605 & & \\
\hline & 5.87 & 715 & & 6.17 & 61 & 594 & & \\
\hline$R 22170$ & 6.50 & 654 & 674 & 5.98 & 60 & 592 & 574 & 85 \\
\hline Binder & 6.37 & 652 & & 6.52 & 57 & 537 & & \\
\hline & 6.99 & 688 & & 7.01 & 64 & 709 & & \\
\hline R22687 & 7.87 & 761 & 695 & 7.26 & 61 & 719 & 651 & 94 \\
\hline Binder & 6.54 & 635 & & 7.11 & 73 & 524 & & \\
\hline
\end{tabular}

Note: ITS: Indirect Tensile Strength

TSR: Tensile Strength Ratio 
Table 7.4 AASHTO T-283 Test Results (150 mm specimens)

\begin{tabular}{|c|c|c|c|c|c|c|c|c|}
\hline & \multicolumn{3}{|c|}{ Dry } & \multicolumn{4}{|c|}{ Wet } & \multirow[b]{2}{*}{$\begin{array}{c}\text { TSR, } \\
\%\end{array}$} \\
\hline & $\begin{array}{c}\text { Air Voids, } \\
\%\end{array}$ & $\begin{array}{c}\text { ITS } \\
(\mathrm{kPa})\end{array}$ & $\begin{array}{c}\text { ITS }_{\text {(Average) }} \\
(\mathrm{kPa})\end{array}$ & $\begin{array}{c}\text { Air Voids, } \\
\%\end{array}$ & $\begin{array}{c}\text { Saturation, } \\
\%\end{array}$ & $\begin{array}{l}\text { ITS, } \\
(\mathrm{kPa})\end{array}$ & $\begin{array}{c}\text { ITS }_{\text {(Average) }} \\
\%\end{array}$ & \\
\hline & 6.99 & 525 & & 7.19 & 62 & 449 & & \\
\hline R21467 & 7.14 & 546 & 583 & 7.04 & 61 & 484 & 560 & 96 \\
\hline Surface & 7.13 & 680 & & 7.06 & 65 & 747 & & \\
\hline & 6.60 & 279 & & 5.90 & 62 & 316 & & \\
\hline$R 22350$ & 6.45 & 287 & 290 & 6.17 & 59 & 296 & 298 & 103 \\
\hline Surface & 6.15 & 304 & & 6.09 & 59 & 280 & & \\
\hline & 6.93 & 372 & & 6.83 & $\overline{63}$ & 345 & & \\
\hline R22170 & 6.81 & 367 & 370 & 7.38 & 71 & 296 & 341 & 92 \\
\hline Surface & 6.61 & 373 & & 6.17 & 67 & 383 & & \\
\hline & 6.78 & 397 & & 7.15 & 75 & 373 & & \\
\hline R22403 & 6.63 & 458 & 425 & 6.85 & 75 & 389 & 396 & 93 \\
\hline Binder & 7.02 & 419 & & 6.08 & 59 & 427 & & \\
\hline & 6.47 & 475 & & 6.68 & $\overline{60}$ & 429 & & \\
\hline R22170 & 6.85 & 441 & 455 & 6.70 & 66 & 455 & 425 & 93 \\
\hline Binder & 7.00 & 454 & & 6.72 & 61 & 391 & & \\
\hline & 6.50 & 435 & & 7.25 & 74 & 342 & & \\
\hline R22687 & 7.26 & 293 & 376 & 6.35 & 72 & 359 & 341 & 91 \\
\hline Binder & 6.40 & 400 & & 7.04 & 79 & 321 & & \\
\hline
\end{tabular}

Note: ITS: Indirect Tensile Strength

TSR: Tensile Strength Ratio 


\section{R21467 SURFACE MIXTURE 60 DEGREES C.}

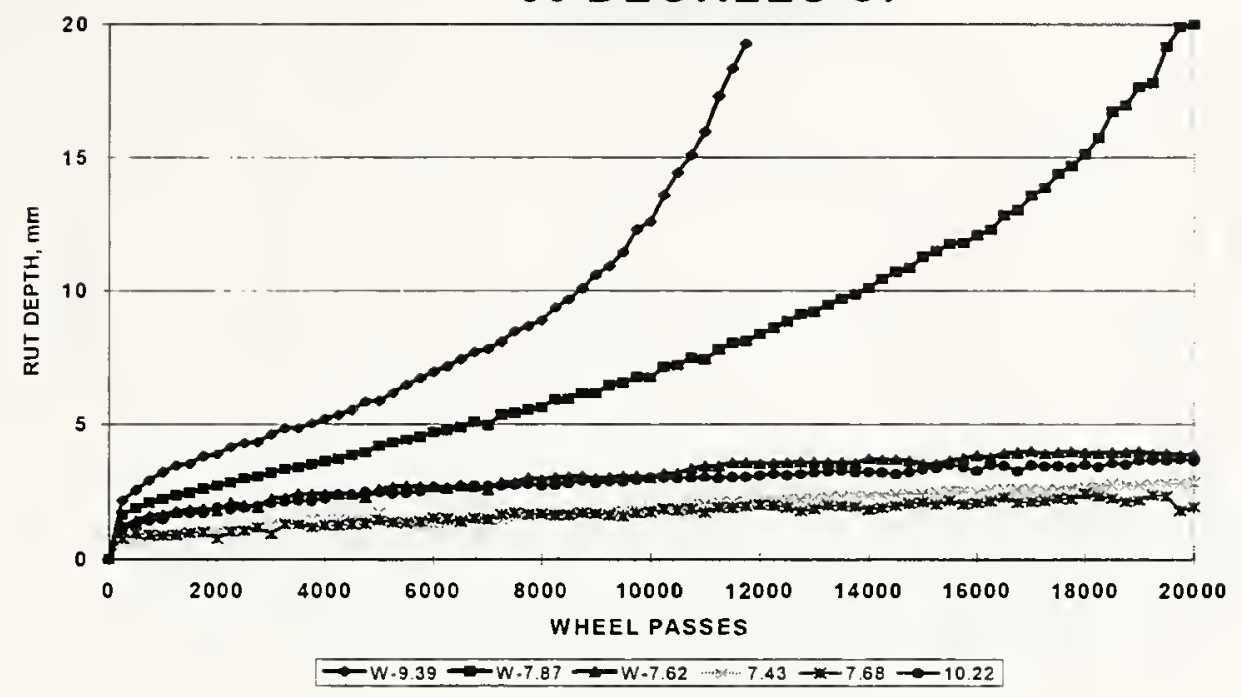

Figure 7.1 Wheel Track Test Results of R-21467, $12.5 \mathrm{~mm}$ Mixture

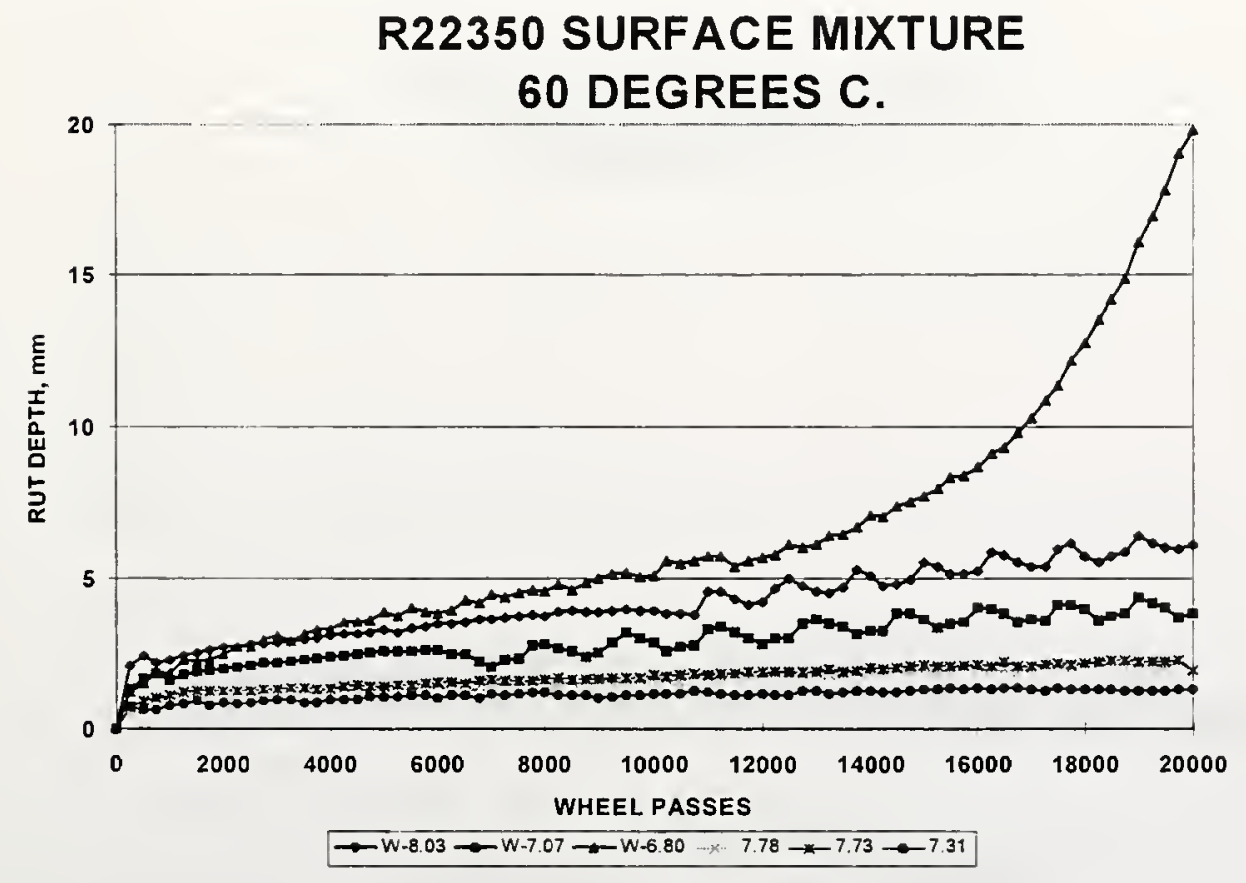

Figure 7.2 Wheel Track Test Results of R-22350, $9.5 \mathrm{~mm}$ Mixture 


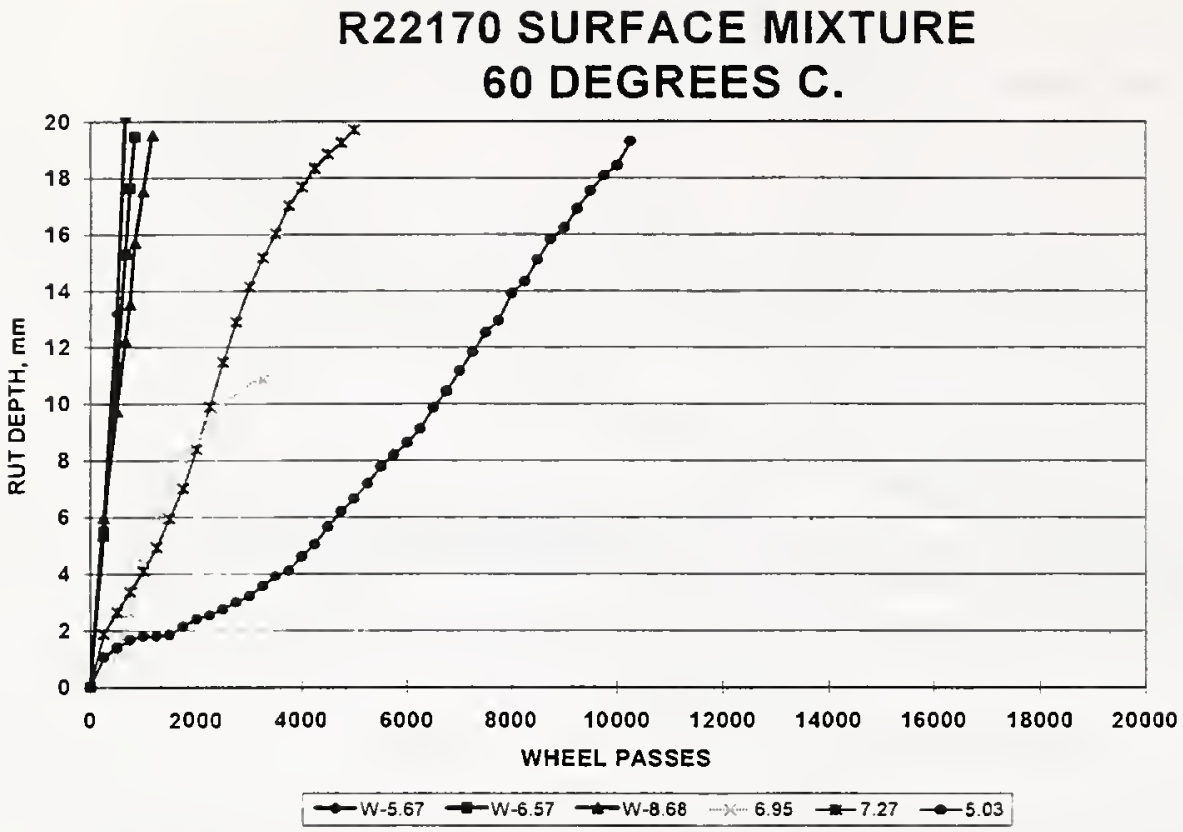

Figure 7.3 Wheel Track Test Results of R-22170, $9.5 \mathrm{~mm}$ Mixture

R22403, BINDER MIXTURE 57.5 DEGREES C.

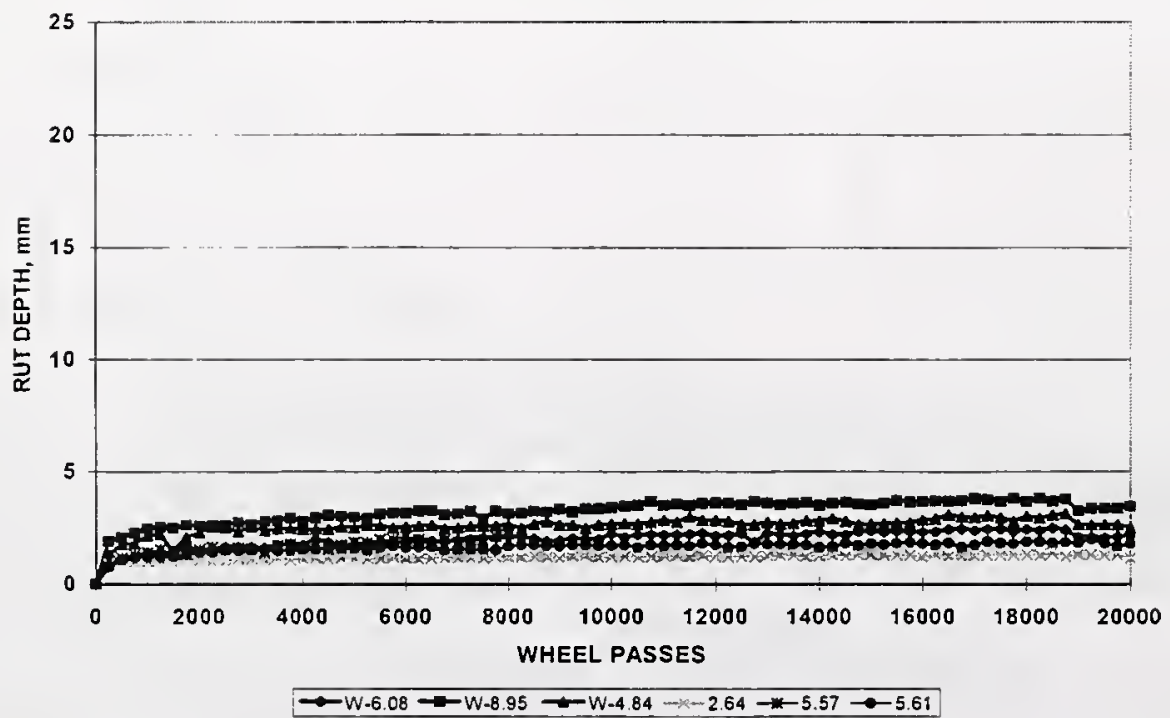

Figure 7.4 Wheel Track Test Results of R-22403, 19.0 mm Mixture 


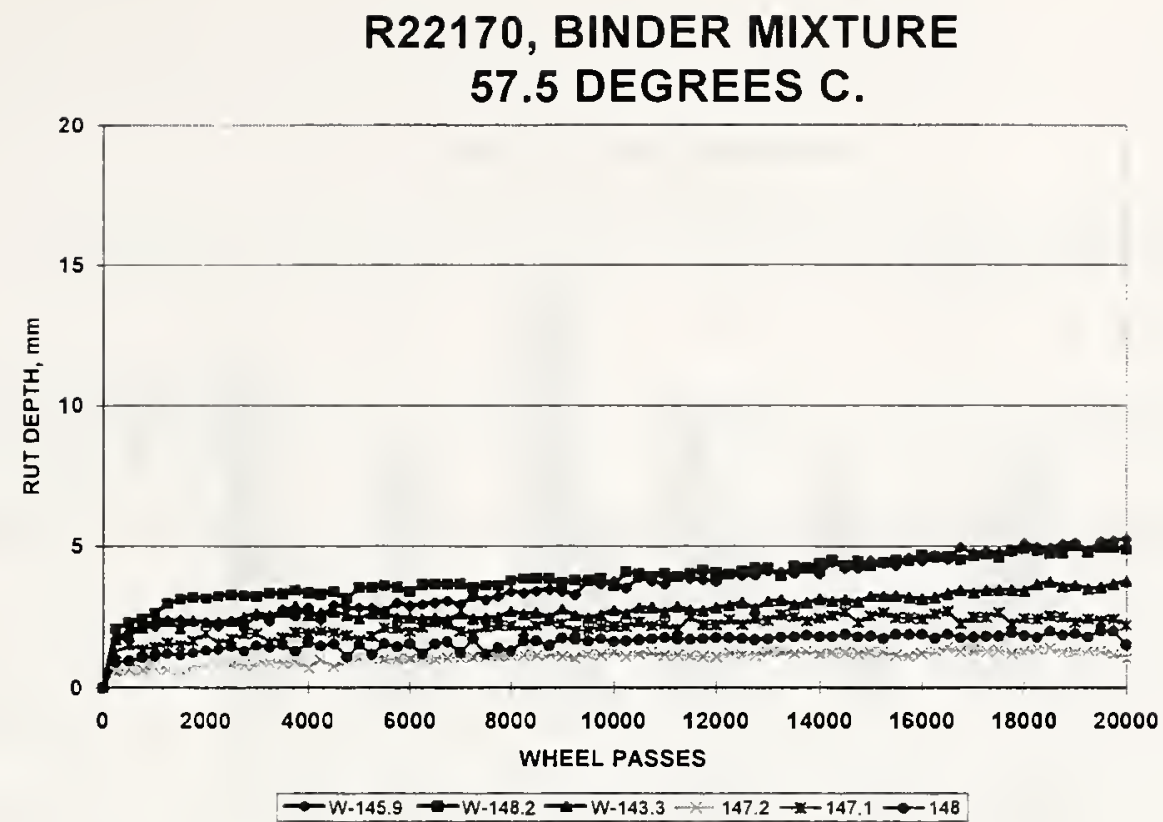

Figure 7.5 Wheel Track Test Results of R-22170, 19.0 mm Mixture

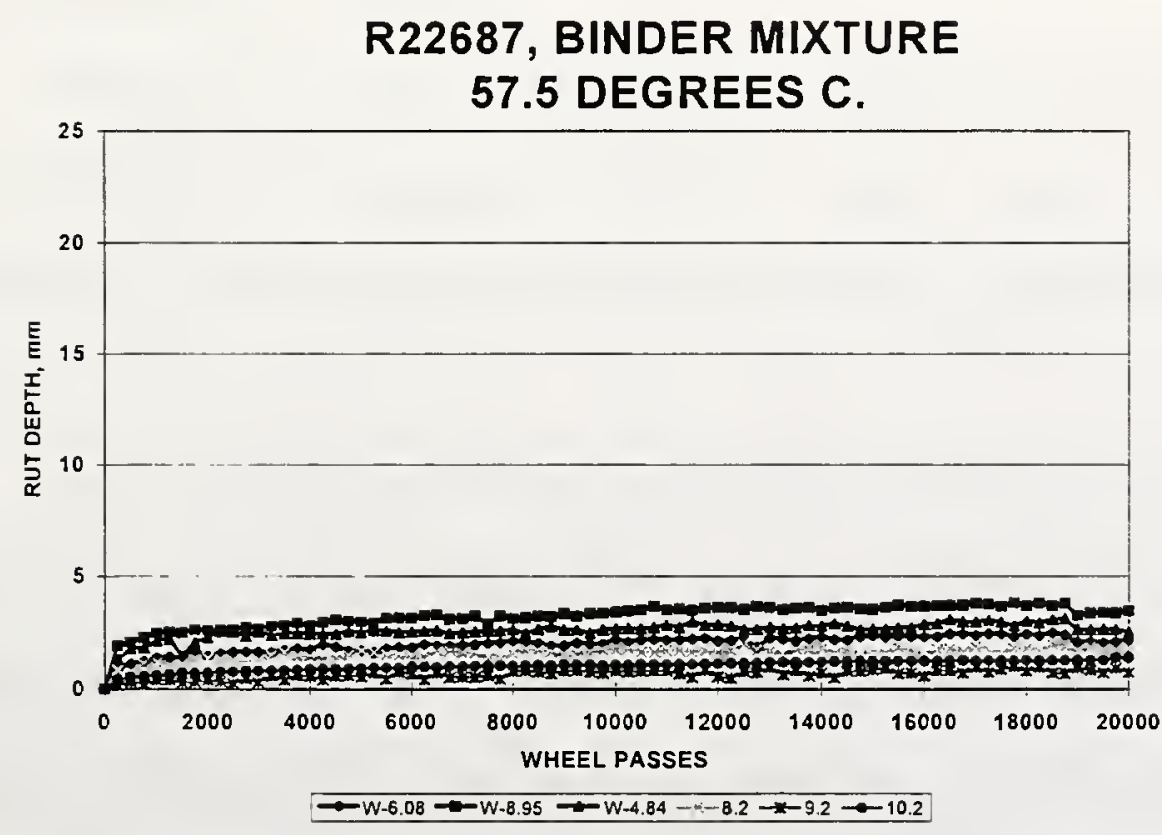

Figure 7.6 Wheel Track Test Results of R-22687, 25.0 mm Mixture 
1996 Superpave Projects

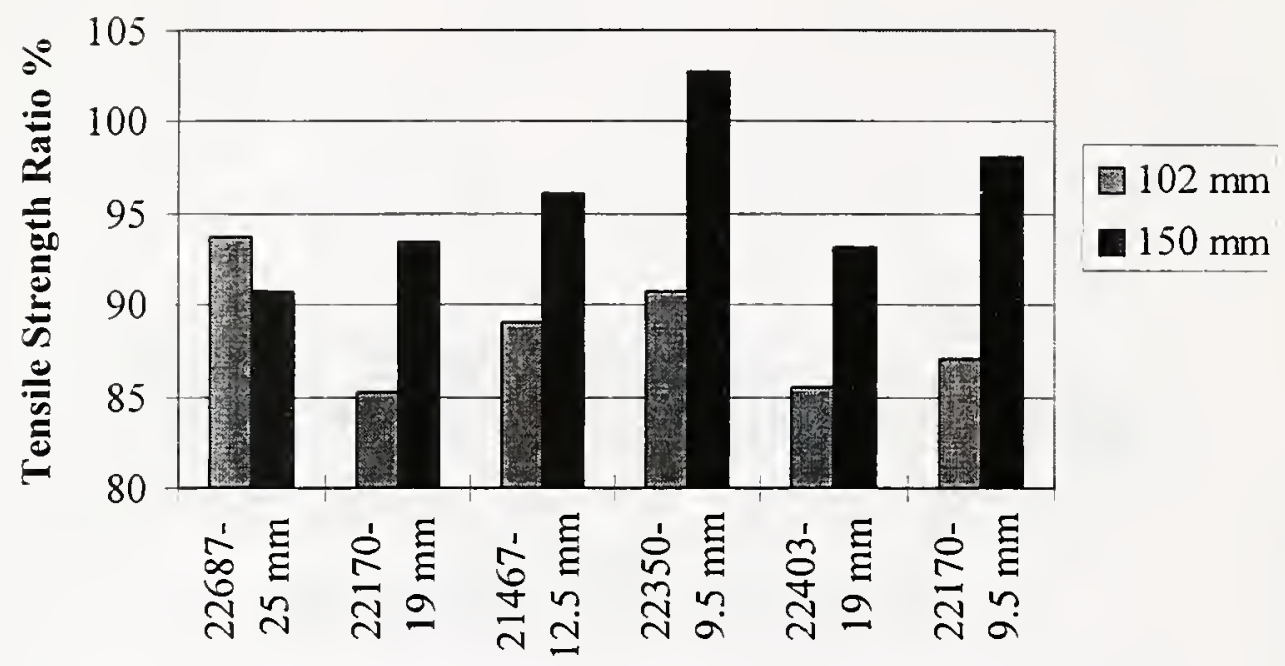

Figure 7.7 TSR Results for AASHTO T-283 Tests (Superpave Mixes) 


\section{Chapter 8 CONCLUSIONS AND RECOMMENDATIONS}

The objective of this study was to determine factors influencing asphalt mixture stripping/rutting potential. Two major variables were selected for the research, aggregate type and antistripping additive. These variables was used in the design of experiment to characterize the bituminous mixture performance relative to environmental factors such as moisture and temperature. Both AASHTO T-283 and the PURWheel laboratory wheel tracking device were incorporated into the study. Currently, mixture stripping potential in the Superpave system is evaluated with AASHTO T-283. The PURWheel device was developed specifically for the study.

Results from AASHTO T-283 tests indicate that moisture conditioning has a significant effect on the stripping potential of the seven mixes tested. That is, the tensile strength of the mixtures was reduced after the environmental procedures in AASHTO T283 tests.

Comparison of the results for the two antistripping agents based on TSR indicates that hydrated lime is more effective than the liquid chemical anti-stripping agent. Hydrated lime produces a slightly higher tensile strength for the mixtures before and after moisture conditioning. The liquid chemical anti-stripping agent increased the tensile strength for the mixtures after moisture conditioning. In some instances it also reduced 
the tensile strength for the mixture before moisture conditioning. Currently mixture stripping potential in the Superpave system is evaluated with AASHTO T-283 and adopts a minimum TSR of $80 \%$ as a design criteria. The reduction of the dry indirect tensile strength by the antistripping agent should be considered as a negative modifier effect.

The PURWheel laboratory wheel tracking device was designed and fabricated to evaluate the stripping/rutting performance of bituminous mixtures. Two specimens can be tested simultaneously. The test environment can be either hot/wet or hot/dry. In this study specimens were compacted to $6 \sim 8 \%$ air voids with the Purdue linear compactor. Specimen dimensions are typically $29.0 \mathrm{~cm}$ wide and $31.0 \mathrm{~cm}$ long. Specimen depth varies depending on the type of mixture being tested. For example, surface, binder and base mixtures are $3.8 \mathrm{~cm}, 5.1 \mathrm{~cm}$, and $7.6 \mathrm{~cm}$, respectively. A pneumatic tire is loaded to achieve a gross contact pressure of about $620 \mathrm{kPa}$ with a $793 \mathrm{kPa}$ tire pressure. The wheel velocity selected for these tests was $33 \pm 2 \mathrm{~cm} / \mathrm{sec}(1.1 \mathrm{ft} / \mathrm{sec}$ or $1 \mathrm{mph})$. In this study, each specimen was subjected to 20,000 wheel passes or until $20.0 \mathrm{~mm}$ of deformation developed. A relationship was also developed between PURWheel "rutting" (downward deformation from initial surface elevation) and actual specimen rutting (straight-line rutting depth) for evaluating the rutting potential of the mix. The $8.9 \mathrm{~mm}$ PURWheel "rutting" is adopted in this for the relative performance evaluation of the mixtures tested at the same temperature.

Laboratory wheel tracking test results for all seven types of mixtures indicated that temperature and moisture conditions were significant. It is obvious that damage 
occurs much faster with wet conditions. Both factors are important in identifying asphalt mixture stripping/rutting potential.

Aggregate type has a significant effect on the wheel track test results. Limestone and slag generally provided better performance than other types of aggregate in this study. Examination of the PURWheel performance of an Indiana \#11 surface mixture shows that a higher percentage of natural sand causes progressively poorer performance. This is not true for binder mixtures for the amount of natural sand utilized.

The antistripping agents did not affect the rutting resistance of mixtures significantly. However, a comparison of hot/wet and hot/dry test results indicates the moisture damage is associated with excessive deformation. The maximum aggregate size and mixture gradation have significant effect on rutting resistance

From PURWheel tests, it is obvious that damage occurs much faster with wet conditions and temperature is an important factor in identifying rutting potential. For both \#11 limestone and dolomite mixes, the number of wheel passes required to reach a $12.7 \mathrm{~mm}\left(1 / 2 \mathrm{in}\right.$.) rut increases as the testing temperature decreases. At $60^{\circ} \mathrm{C}$, both mixes deformed rapidly without a creep deformation stage. This shows that the mix has already lost its integrity and can not resist the $620 \mathrm{kPa}$ tire loading. At $50^{\circ} \mathrm{C}$, the limestone mix is more stable than the dolomite mix. Test results also indicate there is a semi-log relationship between number of wheel passes required to reach a $12.7 \mathrm{~mm}$ rut depth and temperature. The rate of deformation at $40^{\circ} \mathrm{C}$ is ten times greater than that at $25^{\circ} \mathrm{C}$. This means, obviously, that rutting damage will accumulate in the summer at a greater rate, for the same amount of traffic. 
The rutting phenomenon in the PURWheel was modeled through a reasonable approximation of loading and material properties. Results of model verification studies show that a creep model can successfully characterize the pavement material behavior. Based on deformation data from the PURWheel tests, material parameters in the creep model were backcalculated. Good agreement was obtained between predicted and measured deformation in APT tests for the same mixture. The material parameter $m$ is strongly related to temperature and aggregate type. Regression analyses show the parameter $m$ increases with increase of temperature. Mixtures with dolomite aggregate are associated with a higher (less negative) value of $m$.

FEM analysis shows that the effect of temperature can be modeled by a time dependent material model. The PURWheel has already shown its capability to evaluate rutting resistance of asphalt mixtures. Through appropriate level of loading and a reasonable range of temperatures, the asphalt mixture susceptibility to permanent deformation can be predicted within a short period of testing. This test can be utilized as an evaluation tool for the Superpave mix design system.

In this study, the Indiana \#11 dolomite surface mix performed poorly in both wet and dry conditions. There is no question that combination and gradation of the aggregates caused instability of the mixture. This mixture was utilized on Interstate highway I-64 and the pavement exhibited distresses similar to those when the mixture was tested in the PURWheel WTD. Additional study is needed to correlate laboratory test results to field performance. 
Results from PURWheel WTD and AASHTO T-283 tests for the Superpave mixes show the stripping/rutting potential of the mix can be minimized through better selection of materials as well as the mixture gradations. Comparison of the PURWheel performance shows that a higher percentage of natural sand causes progressively poorer performance. The PURWheel highlights the detrimental effect of moisture on rutting. In general, comparison of the AASHTO T-283 TSR and PURWheel results indicate that the TSR does not reflect a mixture's stripping/rutting potential as well as the PURWheel. Application of the $150 \mathrm{~mm}$ SGC specimen for AASHTO T-283 test still needs further evaluation before modification of the current test standard. 


\section{LIST OF REFERENCES}

AASHTO, "Standard Specifications for Transportation Materials and Methods of Sampling and Testing", Part II, American Association of State Highway Officals, 1993.

Aschenbrener, T., and Currier, G., "Influence of Testing Variables on the Results From the Hamburg Wheel-Tracking Device," Final Report, No. CDOT-DTD-R-93-22, Colorado Department of Transportation, December 1993.

Aschenbrener, T., and Stuart, K., "Description of the Demonstration of European Testing Equipment for Hot Mix Asphalt Pavement," Final Report, No. CDOT-DTD-R-92-10, Colorado Department of Transportation, October 1992.

"Cause and Prevention of Stripping in Asphalt Pavements," Education Series No. 10, Asphalt Institute, College Park, MD, 1981.

ASTM, "1993 Annual Book of ASTM Standards," Philadelphia, 1993.

Bolzan, P.E., "Moisture Susceptibility Behavior of Asphalt Concrete and Emulsified Asphalt Mixtures Using the Freeze-Thaw Pedestal Test," Transportation Research Record 1228, Transportation Research Board, National Research Council, Washington, D.C., 1989, pp. 9-16.

Bonaquist, R., Churilla, C., Freund, D., "Effect of Load, Tire Pressure, and Type of Flexible Pavement Response," Public Roads, Vol. 52, No. 1, June 1988, pp. 1-7.

Cominsky, R.J., et al., "The Superpave Mix Design Manual for New Construction and Overlays," SHRP-A-407, Strategic Highway Research Program, National Research Council, Washington, DC, 1994

Croney, D. and Croney, P., "The Design and Performance of Road Pavements," Second Edition, McGraw-Hill Book Company, 1991, pp 15-19.

Decker, D.S., Goodrich, J.L., "Asphalt Cement Properities Related to Pavement Performance," Proceedings, The Association of Asphalt Paving Technologists, Vol. 58, 1989, pp. 503-518. 
Fromm, H.J., "The Mechanisms of Asphalt Stripping from Aggregate Surfaces," Proceedings, The Association of Asphalt Paving Technologists, Vol. 43, 1974, pp. 191223.

Graf, P.E., "Factors Affecting Moisture Susceptibility of Asphalt Concrete Mixes," Paper prepared for presentation at the Annual Meeting of the Association of Asphalt Paving Technologists, Clearwater, Florida, Feb. 17-19, 1986.

Gupta, Anil, "Temperature and Seasonal Corection Factors for Flexible and Rigid Pavements," A Thesis Submitted to the Faculty of Purdue University, August, 1987.

Gzemski, F.C., McGlashan, D.W., and Dolch, W.L., "Thermodynamic Aspects of the Stripping Problem," HRB, Highway Research Circular No. 78, 1968.

Habermann, J.A., "Design Features and a Preliminary Study of Purdue Linear Compactor and the PURWheel Tracking Device," M.S. Thesis, Purdue University, 1994.

Huang, H.M., "Analysis of Accelerated Pavement Tests and Finite Element Modeling of Rutting Phenomenon," A Thesis Submitted to the Faculty of Purdue University, August, 1995.

Huang, H.M., White, T.D., "Minimum Crushed Aggregate Requirements," Draft Finial Report, Joint Highway Reseach Project, FHWA/IN/JHRP-96/23, 1996.

Huang, Y.M., "Pavement Analysis and Design," Prentice Hall, Inc., 1993.

Hubbard, P., "Adhesion of Asphalt to Aggregates in the Presents of Water," HRB Proceedings, National Research Council, Washington, D. C., Vol. 18, Part I, 1938, pp 238-249.

Huekelom, W., Klomp, A.J.G., "Road design and Dynamic Loading," Proceedings, Association of Asphalt Paving Technologists, Ann Arbor, Michigan, 1964.

Indiana Department of Transportation, Standard Specification, 1995.

Kennedy, T.W., Roberts, F.L., and Lee, K.W., "Evaluation of Moisture Susceptibility of Asphalt Mixtures Using the Texas Freeze-Thaw Pedestal Test," , Proceedings of the Association of Asphalt Paving Technologists, Vol. 51, 1982, pp.327-362.

Kennedy, T.W., "Use of Hydrated Lime in Asphalt Paving Mixtures," National Lime Association, Arlington, VA, March 1984. 
Krugler, P., Mounce, J., Bentenson, W., et al, "Asphalt Pavement Rutting in the Western States: Two Texas Lectures and the WASHTO Report," Special Study 26.0, Texas State Department of Highways and Public Transportation, Jan. 1985.

Lottman, R.P., "Predicting Moisture-Induced Damage to Asphalt Concrete," TRB, NCHRP Report, No. 192, National Research Council, Washington, D.C., 1978.

Okamoto, P.A., Packard, R.G., "Effect of High Tire Pressures on Concrete Pavement Performance," 4th International Conference on Concrete Pavement Design and Rehabilitation, Purdue University, April 1989, pp. 61-74.

Parker, Jr.,F., Gharaybeh, F.A., "Evaluation of Indirect Tensile Tests for Assessing Stripping of Alabama Asphalt Concrete Mixtures," Transportation Research Record 1115, Transportation Research Board, National Research Council, Washington, D.C., 1987, pp. 113-124.

Pavement Management Systems Limited, "Study of Asphalt Cement Additives and Extenders," Roads and Transportation Association of Canada, January 1983.

Roberts, F.L., et al, "The effect of Tire Pressures on Flexible Pavements," Report 372-1F, Texas Transportation Institute, Texas A\&M University, 1986.

Roberts, F.L., Kandhal, P.S., Brown, R.E., Lee, D-Y, Kennedy, T.W., "Hot Mix Asphalt Materials, Mixture Design, and Construction," NAPA Education Foundation Incorporated, 1991, pp 68-69.

Roberts, F.L., Kandhal, P.S., Brown, R.E., Lee, D-Y, Kennedy, T.W., "Hot Mix Asphalt Materials, Mixture Design, and Construction," NAPA Education Foundation Incorporated, 1991, pp 98-100.

SAS Institute Inc., "SAS System for Regression," Cary, NC, 1991.

Scheroman, J.a., Mesch, K.A., and Proctor, J.J., "The Effect of Multiple Freeze-Thaw Cycle Conditioning on the Moisture Damage in Asphalt Concrete Mixtures," Proceedings of the Association of Asphalt Paving Technologists, Vol. 55, 1986, pp.213-236.

Taylor, M.A. and Khosla, N.P., "Stripping of Asphalt Pavements: State of the Art," Transportation Research Record 911, Transportation Research Board, National Research Council, Washington, D.C., 1983, pp. 150-158.

Tunnicliff, D.G., Root, R.E., "Testing Asphalt Concrete for Effectiveness of Antistripping Additives," Proceedings of the Association of Asphalt Paving Technologists, Vol. 52, 1983. 
Tunnicliff, D.G., Root, R.E., "Use of Antistripping Additives in Asphalt Concrete Mixtures," NCHRP Report \#274, Transportation Research Board, National Research Council, Washington, D.C., December 1984.

Tunnicliff, D.G., "Performance of Antistripping Additives," Preprint of the Association of Asphalt Paving Technologists, Vol. 66, 1997.

Van Draat, W.E.F., Sommer, P., "Ein Geratzur Bestimmung der Dynamischen Elastizitats modulu von Asphalt," Strasse und Autobahn, Vol. 35, 1965.

White, T.D., "Stripping in HMA Pavements," Hot Mix Asphalt Technology, National Asphalt Pavement Association (NAPA), Fall 1987, pp: 18-20.

Williams, R.C., Duncan, G.R., Jr., White, T.D., "Sources, Measurement and Effects of Segregated Hot Mix Asphalt Pavements," Final Report, Joint Highway Reseach Project, FHWA/NN/JHRP-96/16, 1996.

Zaghloul, S.M., "Non-Linear Dynamic Analysis of Flexible and Rigid Pavements," A Thesis Submitted to the Faculty of Purdue University, May, 1993. 



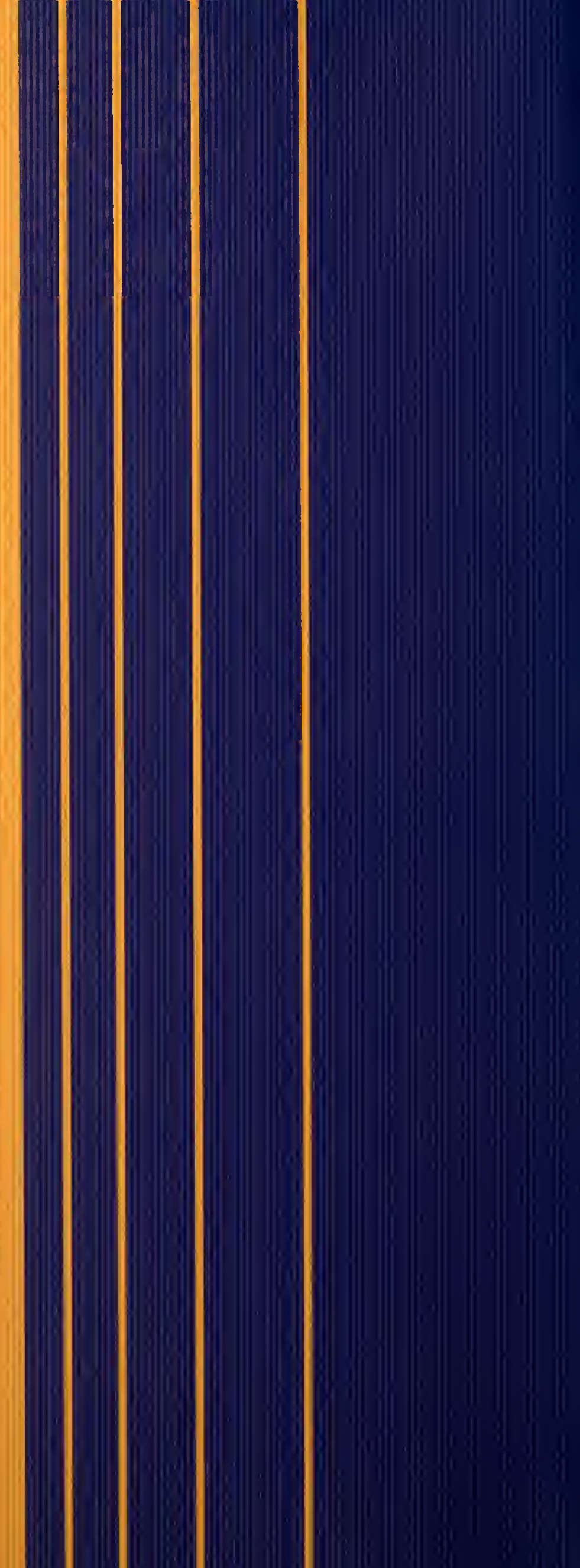

